Aldo Roberto Ometto

\title{
AVALIAÇÃO DO CICLO DE VIDA DO ÁLCOOL ETÍLICO HIDRATADO COMBUSTÍVEL PELOS MÉTODOS EDIP, EXERGIA E EMERGIA
}

Tese apresentada à Escola de Engenharia de São Carlos da Universidade de São Paulo, como parte do requisitos para a obtenção do Título de Doutor em Engenharia (Hidráulica e Saneamento)

Orientador: Prof. Tit. Woodrow Nelson Lopes Roma Co-orientador: Prof. Dr. Enrique Ortega 
FOLHA DE JULGAMENTO

Candidato: Engenheiro ALDO ROBERTO OMETTO

Tese defendida e julgada em 18-03-2005 perante a Comissão Julgadora:

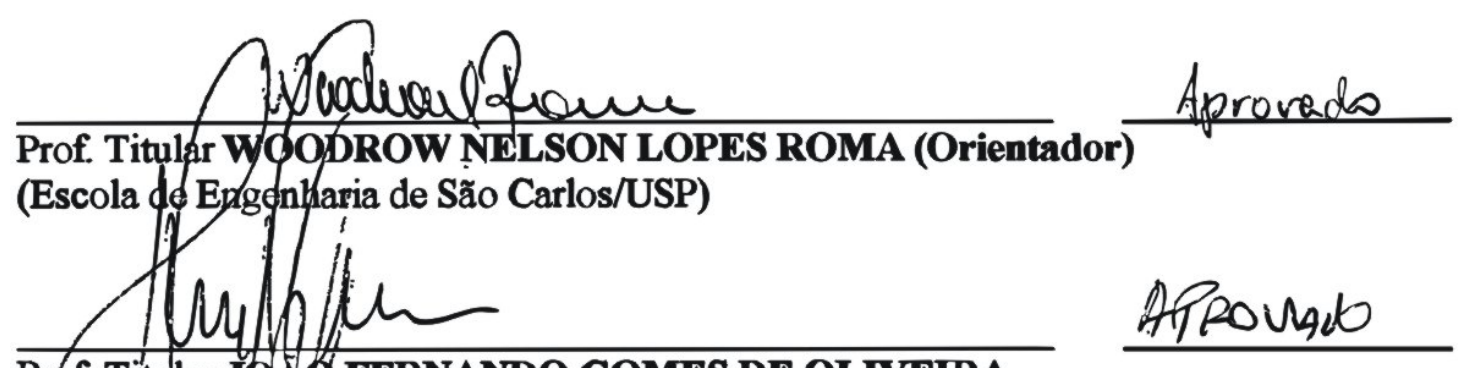

Prof. Títular Jo 0 o FERNANDO GOMES DE OLIVEIRA

(Escola de Engenharia de São Carlos/USP)

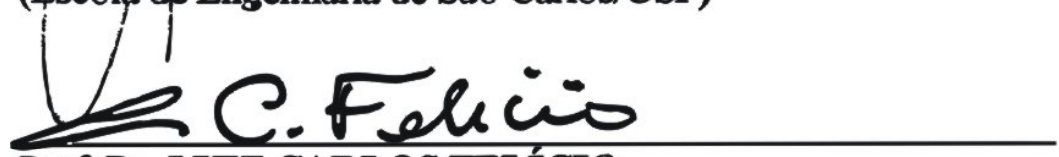

Prof. Dr. LUIZ CARLOS FELÍCIO

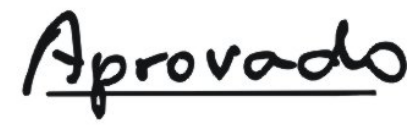

(Escola de Engenharia de São Carlos/USP)

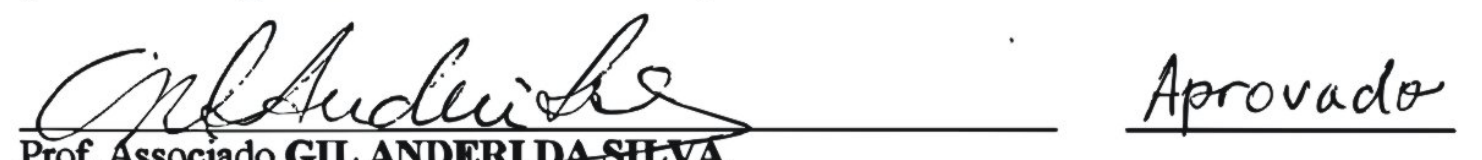

Prof. Associado GIL ANDERIDASEIVA

(Escola Politécnica/USP)

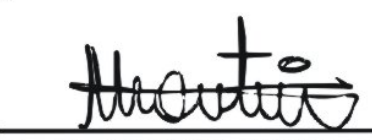

Dr. MARCOS ROBERTO MONTEIRO

Aprovado

(Pesquisador/UFSCar)

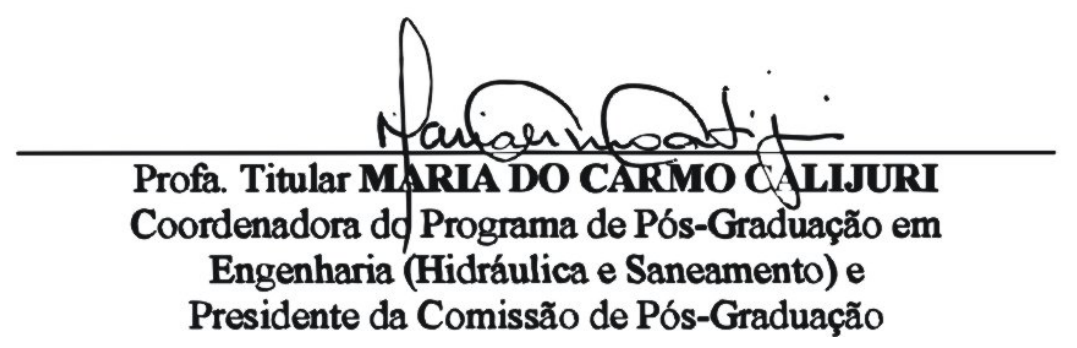


Dedico esse trabalho a todos que colaboraram com a minha formação acadêmica, desde o meu primeiro professor, meu pai. 


\section{AGRADECIMENTOS}

Ao grande mestre, professor e orientador Prof. Tit. Woodrow Nelson Lopes Roma, pela dedicação, apoio e orientação.

À Fundação de Amparo à Pesquisa do Estado de São Paulo (FAPESP) pela concessão da bolsa de doutorado e pelo apoio financeiro para a realização do trabalho de doutorado, para o estágio na Universidade Técnica da Dinamarca (DTU) e para a participação em dois eventos científicos internacionais.

Ao Grupo de Adequação Ambiental em Manufatura (AMA), do Núcleo de Manufatura Avançada (NUMA) e ao Instituto Fábrica do Milênio (IFM), pela grande possibilidade de trabalhar em um ambiente de pesquisa aplicada e de desenvolver a área ambiental em um contexto integrado na manufatura. Nesse contexto, gostaria de agradecer, especialmente, ao Prof. Tit. João Fernando Gomes de Oliveira (Moringa) e aos grandes amigos do chão de fábrica: Américo (Véio), Salete, Dinho, Fábio, Adriano, Eraldo, Tobias, Marcelo, em nome de todas as grandes personalidades deste laboratório e aos membros do AMA que auxiliaram a realização dos workshops, dos trabalhos, das reuniões e do desenvolvimento desse grupo. Em especial, quero agradecer todo o apoio e dedicação do irmão Américo aos trabalhos do AMA e pela amizade sincera.

Aos Professores Michael Hauschild e Leo Alting, da Universidade Técnica da Dinamarca (DTU), Department of Manufacturing Engineering and Management, pela supervisão e coordenação do estágio no doutorado. Além disso, agradeço o voto de confiança no trabalho de cooperação em Engenharia do Ciclo de Vida e Sustentabilidade com o grupo de Adequação Ambiental em Manufatura (AMA).

À Universidade Técnica de Berlin (TUBerlin), especialmente ao Prof. Seliger e ao amigo Carsten Franke, pelos trabalhos de cooperação em Engenharia do Ciclo de Vida e Sustentabilidade com o AMA.

Ao grande amigo, ambientaleiro, sempre orientador e grande incentivador desse trabalho, Prof. Tit. Marcelo Pereira de Souza.

Aos grandes amigos do Lab. SIG - Agenda Ambiental - pela harmonia no trabalho, esperança e convicção na causa ambiental: Marcelo Montaño (Minduim), Prof. Victor Ranieri (Vitinho), Denis, Nágila, em nome dos quais agradeço todos os demais.

Ao grande mestre Prof. Geraldo Lombardi o qual mostra, além de todos os ensinamentos da Termodinâmica, que o entusiasmo e amor pela Causa transforma o Homem e o faz mais nobre. Também agradeço a possibilidade de participar no projeto de GERIPA - Geração de Energia Renovável e Produção de Alimentos junto com nosso amigo Pedro, da Universidade de Cuba. aplicada.

À Prof. Silvia A. Nebra pelos grandes ensinamentos da Termodinâmica

Ao Prof. Enrique Ortega pelos trabalhos conjuntos e pela co-orientação.

À EMBRAPA, pelo apoio e experiência profissional adquirida como pesquisador. 
À Associação Brasileira de Normas Técnica (ABNT) pela normas da Série NBR ISO 14.040.

Aos grandes amigos e "orientados" de Iniciação Científica, Felipe Scanavini e Bruno Teodoro, pelo grande auxílio no desenvolvimento do trabalho.

Ao teacher Prof. Davi Antunes Nardi, da Faculdade de Economia da UNICAMP, pelas sugestões e discussões acaloradas a respeito da valoração ambiental.

Ao Departamento de Hidráulica e Saneamento, à Escola de Engenharia de São Carlos e à Universidade de São Paulo, em nome de todos os funcionários e professores, meu profundo agradecimento e respeito.

A todos os amigos de Sanca que dividimos grandes momentos inesquecíveis.

À minha irmã, Ana Maria, e ao meu cunhado, Paulo, pelo apoio constante.

Aos meus pais, Duvílio Aldo Ometto e Maria Helena de Toledo Ometto, pela constante força, carinho e amor durante toda a vida.

À Renata, a quem me mostrou o real significado do amor pelo companheirismo, ajuda, força, carinho e paz de todas as horas.

À DEUS, por ter me possibilitado a realização desse trabalho com saúde e muitas felicidades e ter me trilhado esse caminho maravilhoso de VIDA. 
“...Decepar a cana

Recolher a garapa da cana Roubar da cana a doçura do mel

Se lambuzar de mel Afagar a terra Conhecer os desejos da terra Cio da terra, a propícia estação E fecundar o chão"

(O Cio da Terra, Milton Nascimento) 


\section{RESUMO}

OMETTO, A. R. (2005). Avaliação do ciclo de vida do álcool etílico hidratado combustível pelos métodos EDIP, Exergia e Emergia. Tese (Doutorado) Escola de Engenharia de São Carlos, Universidade de São Paulo, São Carlos, 2005.

Uma das formas mais integradas, completas e eficazes para a gestão ambiental de atividades produtivas é baseada no ciclo de vida do produto, sendo a Avaliação do Ciclo de Vida sua principal ferramenta. O produto avaliado é o álcool etílico hidratado combustível, por ser passível de melhorias ambientais durante seu ciclo de vida, alternativo frente aos fósseis e de grande importância estratégica para o Estado de São Paulo e para o Brasil. O objetivo é a avaliação do ciclo de vida do álcool etílico hidratado combustível utilizando o método EDIP (Environmental Development of Industrial Products) e introduzindo as avaliações exergéticas e emergéticas na avaliação e valoração do impacto. A estrutura metodológica está baseada nas normas da série NBRISO 14.040 e ISO 14.040. Os resultados do EDIP mostram que a atividade da colheita de cana apresenta o maior potencial de impacto para o consumo de recursos renováveis, o aquecimento global, a formação fotoquímica de ozônio troposférico, a acidificação e a toxicidade humana. O preparo do solo apresenta maior potencial para o consumo de recursos não renováveis e para a ecotoxicidade da água. $O$ trato cultural apresenta maior influência na eutrofização e na ecotoxicidade do solo. Pela Exergia, verifica-se que, para cada litro de álcool consumido, há uma perda de exergia pelas emissões atmosféricas de seu ciclo de vida, considerando que $25 \%$ da cana colhida seja crua, equivalente à exergia de, aproximadamente, 1,38 litro de álcool. Pela Emergia, $69 \%$ do consumo de energia solar equivalente é realizado pelo veículo automotor. Portanto, a fim de adequar ambientalmente o ciclo de vida do etanol hidratado combustível, indica-se a eliminação da queimada, a redução do uso de agrotóxicos, de combustível fóssil e formas mais eficientes de uso do álcool combustível.

Palavras-chaves: Avaliação do ciclo de vida (ACV); gestão ambiental de processo e produto; adequação ambiental de empresas; avaliação de impacto ambiental; valoração ambiental; EDIP; Exergia; Emergia; álcool combustível. 


\section{ABSTRACT}

OMETTO, A. R. (2005). Life cycle assessment of hydrated ethylic alcohol fuel by EDIP, Exergy and Emergy methods. Ph.D. Thesis - Escola de Engenharia de São Carlos, Universidade de São Paulo, São Carlos, 2005.

One of the most integrated, complete and efficacious means for the environmental management of productive activities is based on the life cycle of the product, whose main tool is the Life Cycle Assessment. The assessed product is the hydrated ethylic alcohol fuel because of the environmental improvement possibilities during its life cycle, an alternative for fossil fuel and its great strategic importance to Sao Paulo State and Brazil. The goal is the life cycle assessment of hydrated ethylic alcohol fuel using EDIP (Environmental Development of Industrial Products) method and introducing Exergy and Emergy methods on the impact assessment and valuation. The methodological structure is based on the norms NBR-ISO 14.040 and ISO 14.040 series. The EDIP results show that the sugar cane harvesting activity presents the highest potential impact for the renewable resources consumption, the global warming, the photochemical ozone formation, the acidification and the human toxicity. The soil preparation activity presents the highest potential for the nonrenewable resources and the ecotoxicity in water. The cultivation activity presents the highest potential for the nutrient enrichment and the ecotoxicity in soil. With the Exergy method, it is verified that for each liter of alcohol consumed, there is an Exergy lost by the atmospheric emissions of its life cycle, considering $25 \%$ of the total sugar cane cultivated and harvested is not burned, which is equivalent to the Exergy of, approximately, 1.38 liter of alcohol. By the Emergy method, $69 \%$ of the equivalent solar energy consumption is performed by the vehicle. Therefore, in order to achieve an environmentally benign life cycle of the hydrated ethylic alcohol fuel, it is indicated the sugar cane burning elimination, pesticides and fossil fuel reduction and more efficient manners of using alcohol fuel.

Keywords: Life cycle assessment (LCA); environmental management of process and product; industries environmental benign; environmental impact assessment; environmental valuation; EDIP; Exergy; Emergy; fuel alcohol. 


\section{SUMÁRIO}

Capítulo 1. Introdução 1

Capítulo 2. Revisão Bibliográfica 8

2.1. Gestão ambiental do processo ao produto 8

2.2. O ciclo de vida do álcool etílico hidratado combustível 22

2.3. Valoração ambiental pela Termodinâmica 36

2.3.1. Evolução dos aspectos ambientais na Termodinâmica 42

2.3.2. Valoração ambiental pela Exergia 48

2.3.3. Valoração ambiental pela Emergia 51

Capítulo 3. Metodologia 53

3.1. Definição do objetivo e escopo 57

3.2. Análise de inventário $\quad 60$

3.3. Avaliação de impacto do ciclo de vida 63

3.3.1. EDIP 64

3.3.2. Exergia 73

3.3.3. Emergia 82

3.3.4. Limitações e diferenças dos métodos de AICV 93

3.3.5. Elementos opcionais da AICV 100

3.4. Interpretação do ciclo de vida 101

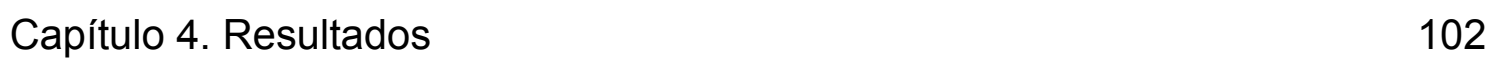

4.1. Definição do objetivo e do escopo 102

4.2. Análise de inventário do ciclo de vida 124

4.3. Avaliação de impacto do ciclo de vida 155

4.3.1. Avaliação de impacto pelo método EDIP 155

4.3.2. Avaliação de impacto e valoração ambiental pela Exergia 162

4.3.3. Avaliação de impacto e valoração ambiental pela Emergia 167

Capítulo 5. Conclusões 180

$\begin{array}{ll}\text { Referências Bibliográficas } & 184\end{array}$ 


\section{Capítulo 1. Introdução}

O padrão de vida de uma sociedade já foi determinado somente pelos serviços e produtos disponíveis, segundo Degarmo et al. (1997). Atualmente, esse conceito está ampliado, englobando parâmetros de qualidade do meio ambiente e a relação justa com a humanidade.

A área ambiental começou a ser discutida nas relações internacionais a partir da década de 1960, segundo Elliott (1994), especificamente em 1968, com o Clube de Roma e, posteriormente, em 1972, com a realização da $1^{\text {a }}$ Conferência Mundial sobre o Meio Ambiente, em Estocolmo. Este evento representou um marco político na conscientização mundial dos problemas ambientais, produzindo, como principal documento a Declaração sobre o Ambiente Humano.

Vinte anos depois, em 1992, durante a Conferência das Nações Unidas sobre Meio Ambiente e Desenvolvimento (CNUMAD), realizada no Rio de Janeiro, foram assinados importantes documentos pelos países participantes, tais como: Declaração do Rio sobre Meio Ambiente e Desenvolvimento, Agenda 21, Princípios para a Administração Sustentável das Florestas, Convenção da Biodiversidade e Convenção sobre a Mudança do Clima. Estes, se ratificados pelo Congresso ou pelo Parlamento do respectivo país, passam a ter força de lei.

Da mesma forma, em âmbito nacional, há regulamentações da área ambiental, por meio das legislações nacionais (Constituição Federal, Lei Federal 6938/81, CONAMA 01/86, CONAMA 20/86, entre outras), estaduais e municipais que buscam coibir o avanço desenfreado das atividades humanas.

Tal reforma no modo de produção capitalista vigente, citada por Souza (2000), é uma das formas de incorporar as questões ambientais (inclusas nos conjuntos as sociais) no âmbito decisório. Outra forma, ainda sob a ótica da 
reforma, refere-se à pressão do mercado consumidor pela aquisição de produtos ou de serviços ambientalmente adequados.

$\mathrm{Na}$ visão empresarial, tal demanda torna o aspecto ambiental um diferencial estratégico de negócio, o qual deve buscar não apenas a satisfação imediata do cliente, mas a da sociedade, já que se reconhece que as gerações futuras têm o mesmo direito à qualidade ambiental usufruída pelas atuais.

Para Magnani (2000), a adequação ambiental em manufatura inicia-se pela observação desta como um organismo que está inserido em um contexto maior, modificando o meio físico e antrópico ao seu redor e dele recebendo influência.

Assim, a avaliação ambiental faz parte das funções empresariais e pode ser realizada por meio de um Sistema de Gestão Ambiental (SGA), pois ele é a parte responsável, do sistema de gerenciamento geral, pelas etapas de desenvolvimento, de implementação, de execução, de avaliação e de manutenção da política ambiental da companhia, segundo Associação Brasileira de Normas Técnicas (ABNT) (1996).

Souza (2000) explica que a avaliação ambiental deve basear-se no cruzamento da tipologia, ou seja, no estudo das especificidades da atividade, incluindo o material, a energia, os serviços, o processo de produção, entre outros, e da caracterização ambiental, a fim de se obter, respectivamente, maior eficiência no processo e localização ambientalmente adequada.

Em outras palavras, Macedo (1995) explica que a avaliação ambiental tem por objetivo fundamentar e otimizar os processos decisórios que envolvem as atividades transformadoras do meio, melhorando o seu desempenho ambiental a partir da minimização de suas adversidades e da maximização de seus benefícios.

Com essa finalidade, aliada, principalmente, à busca da otimização dos processos produtivos e à redução dos custos, as empresas passam a adotar uma postura pró-ativa, a fim de não gerar, ou, ao menos de minimizar, os resíduos na fonte e, conseqüentemente, seus impactos ambientais ${ }^{1}$.

\footnotetext{
${ }^{1}$ Impacto ambiental: qualquer modificação do meio ambiente, adversa ou benéfica, que resulte, no todo ou em parte, das atividades, produtos ou serviços de uma organização (ABNT, 1996).
} 
Tal postura pode compor o SGA da empresa, o qual pode ser baseado no processo ou no produto:

a) Gestão do processo: controle e prevenção da poluição, por meio de técnicas de redução de perdas, de melhoria da eficiência, entre outras, aplicadas ao processo produtivo;

b) Gestão do produto: a gestão do produto baseia-se em minimizar não só a poluição durante a produção, mas todos os impactos ambientais associados ao ciclo de vida completo de um produto, desde a extração da matéria-prima, o beneficiamento, o transporte, a produção, a distribuição, o consumo, a reciclagem até a disposição final.

Um SGA com foco no produto deve, portanto, ser baseado em métodos criativos e holísticos, para a aplicação de técnicas que permitam à atividade planejar-se, crescer, manter-se, controlar e melhorar continuamente seus sistemas internos, seu processo produtivo, o ciclo de vida de seu produto e toda sua manutenção, de acordo com os requisitos ambientais legais e com os padrões de qualidade ambiental exigidos pelo mercado, pelas normas e pela sociedade em geral.

Para tanto, as empresas buscam as ferramentas adequadas a avaliar seu desempenho ambiental. Uma delas, com foco no produto e indicada por Alting e Legarth (1995), é a Avaliação do Ciclo de Vida (ACV), a qual, segundo ABNT (2001), é a compilação e a avaliação das entradas, das saídas e dos impactos ambientais potenciais de um sistema de produto ${ }^{2}$, ao longo de seu ciclo de vida, como mostra a figura 1.

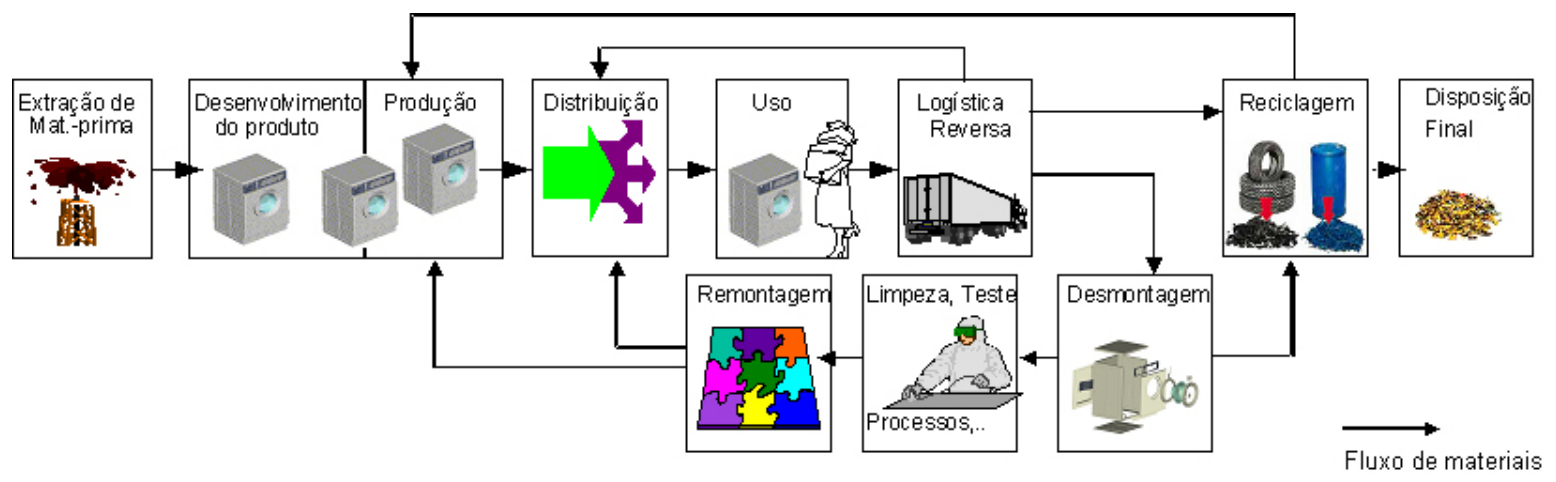

Figura 1- Ciclo de vida do produto

Fonte - FRANKE (2004)

\footnotetext{
${ }^{2} \mathrm{O}$ sistema de produto é o conjunto de unidades de processo, conectadas, material e energeticamente, que realiza uma ou mais funções definidas. O termo "produto" usado isoladamente não inclui somente sistemas de produto, mas pode incluir sistemas de serviço (ABNT, 2001).
} 
A ACV se apresenta como uma importante ferramenta para subsidiar as etapas do desenvolvimento do produto, a gestão da produção, o pós-uso, a logística convencional e a reversa, entre outras, a partir da compilação de informações e das avaliações técnicas.

De acordo com Barnthouse et al. (1997), os estudos de ACV originaramse do intuito de analisar o uso da matéria-prima e da energia associados a sistemas produtivos, no final da década de 1960. Porém, no Brasil, são raros os estudos, geralmente realizados pela Academia ou por empresas multinacionais, sendo os destas de difícil acesso e com base em softwares de arquitetura fechada.

Atualmente, o mercado globalizado, principalmente o europeu, exige algumas obrigações dos produtores, quanto ao desempenho ambiental de seus produtos. Isso é expresso pela rotulagem de terceira parte, a ser normatizada pela International Organization for Standardization (ISO), a partir de 2006, e que poderá vir a ser uma barreira internacional aos produtos. Esta norma está em elaboração pelos comitês técnicos da ISO, que já definiram que a ferramenta para a obtenção do rótulo ambiental de terceira parte deve ser a ACV. Portanto, as empresas nacionais precisam estar aptas a participar do mercado em âmbito mundial e, para isso, precisam aparelhar-se tecnicamente e contar com recursos humanos qualificados, frente às exigências internacionais no âmbito ambiental.

A fim de contribuir com esse processo, o Grupo de Adequação Ambiental em Manufatura (AMA), do Núcleo de Manufatura Avançada (NUMA) desenvolve suas pesquisas na área de sustentabilidade de processo, de produto e de gestão de empresas. O Departamento de Hidráulica e Saneamento (SHS) e o de Engenharia de Produção (SEP), da Escola de Engenharia de São Carlos (EESC), por meio dos professores, alunos de pósgraduação e de graduação participam ativamente das atividades do AMA. Nesse contexto, este trabalho foi desenvolvido com o suporte da Fundação de Amparo à Pesquisa do Estado de São Paulo (FAPESP), o que possibilitou a realização de um estágio na Universidade Técnica da Dinamarca (DTU), no Department of Manufacturing Engineering and Management, sobre ACV, sob a supervisão do Prof. Michael Hauschild e a coordenação do Prof. Leo Alting. 
O trabalho de doutorado apresenta um estudo de ACV, baseado na estrutura metodológica da série ISO 14.040, e na sua correspondente brasileira NBR ISO 14.040, e em métodos técnico-científicos adequados aos objetivos do estudo.

O produto avaliado é o álcool etílico hidratado, cuja função é ser combustível de veículos automotores, e cuja matéria-prima é a cana-de-açúcar.

A cana-de-açúcar ocupava, na safra de 2003/2004, 5,4 milhões de hectares do território brasileiro, caracterizando-se como uma das principais fonte de renda da área agrícola do Brasil e do Estado de São Paulo, este com $60 \%$ da produção brasileira, segundo o Instituto Brasileiro de Geografia e Estatística (IBGE) (2005).

$\mathrm{Na}$ safra de 2003/2004, a produção do setor sucroalcooleiro foi de 338.316.619 t de cana-de-açúcar; 468.094 .060 sacas de $50 \mathrm{~kg}$ de açúcar, ou seja, $23.404 .703 \mathrm{t}$ de açúcar; $8.577 .410 \mathrm{~m}^{3}$ de álcool anidro; $5.530 .468 \mathrm{~m}^{3} \mathrm{de}$ álcool hidratado, contabilizando $14.107 .878 \mathrm{~m}^{3}$ de álcool total. Somente o Estado de São Paulo é responsável pela produção de $8.806 .942 \mathrm{~m}^{3}$ de álcool de álcool total, o que significa $62,43 \%$ de da produção total de álcool do Brasil, segundo Unica (2004).

Segundo Magalhães (2004), no país há 3,5 milhões de veículos movidos a álcool e, a partir de 2003, os veículos bicombustíveis (gasolina e álcool) representam outra opção para o seu uso. No acumulado dos oito primeiros meses do ano de 2004, as vendas de carro a álcool e bicombustível ficaram em 212.094 unidades (182.274 unidades de veículos bicombustíveis), com um crescimento de $549 \%$ sobre o mesmo período do ano passado.

Além disso, há o aumento da demanda internacional, principalmente da Europa e Japão, para fontes renováveis de energia. Esta demanda internacional é ratificada pela entrada em vigor do Protocolo de Kyoto em fevereiro de 2005, o qual busca reduzir as emissões globais de gases de efeito estufa causados, principalmente, pelo uso de combustíveis fósseis.

Portanto, com o crescimento da demanda do álcool, a importância deste combustível é realçada, assim como a necessidade de estudos que avaliem seus impactos ambientais.

Deste modo, busca-se elaborar um estudo da avaliação de ciclo de vida de um produto brasileiro, alternativo frente aos fósseis, de grande importância 
estratégica para o país e com a possibilidade de ser uma opção para os usuários do combustível frente ao Mecanismo de Desenvolvimento Limpo (MDL), estabelecido pelo Protocolo de Kyoto. Pode-se, ainda, citar algumas justificativas pontuais para a realização de um estudo de ACV do álcool combustível hidratado:

- o álcool combustível é uma alternativa de fonte renovável frente ao combustível fóssil;

- o Brasil é o país que apresenta o menor custo de produção do álcool, segundo Bacchi (2004) e o Estado de São Paulo é o maior produtor nacional de álcool, com características de solo e clima propícios à cultura da cana, modernas tecnologias e experiência para produzir o álcool combustível a partir da cana-de-açúcar;

- o álcool combustível tem um alto potencial para ser ambientalmente adequado;

- o álcool combustível apresenta menor quantidade de emissão de poluentes durante sua combustão em comparação com os combustíveis fósseis, segundo Copersucar (1989);

- há a necessidade de indicação de melhorias de suas atividades de modo integrado e não pontual;

- a necessidade mundial de combustíveis renováveis com qualidades ambientais durante todo seu ciclo de vida e

- a possibilidade de transformação do setor sucroalcooleiro em um complexo energético mais eficiente, renovável e com melhores qualidades ambientais.

O objetivo geral do trabalho é a avaliação do ciclo de vida do álcool etílico hidratado combustível utilizando um método convencional e introduzindo avaliações de impactos ambientais baseadas na Termodinâmica. Os objetivos específicos são:

- realizar o inventário do ciclo de vida do álcool etílico hidratado combustível;

- avaliar o ciclo de vida do álcool etílico hidratado combustível frente a categorias de impactos ambientais; 
- valorar os insumos, serviços e as emissões atmosféricas do seu ciclo de vida em termos energéticos;

- fornecer subsídios para identificação de oportunidades de melhorias ambientais e de eficiências energética e produtiva no ciclo de vida do álcool combustível e

- comparar as aplicações das avaliações de impactos ambientais calculadas pelos diferentes métodos.

A importância da avaliação das emissões atmosféricas é ratificada pela sua quantidade e sua relevância ambiental, mostrada em Ometto, A. (2000). Além disso, é pelo meio atmosférico que o ciclo de vida do álcool se completa, com a absorção do gás dióxido de carbono $\left(\mathrm{CO}_{2}\right)$ durante o crescimento da cana.

O método para a realização da ACV é o EDIP (Environmental Design of Industrial Products), utilizando-se, para a fase da avaliação do impacto do ciclo de vida, além do EDIP, dois métodos da Termodinâmica.

Atualmente, a aplicação dos métodos da Termodinâmica à questão ambiental está em desenvolvimento. Este trabalho indica a avaliação de impacto e a valoração ambiental de alguns aspectos (insumos, serviços e emissões) ligados a processos produtivos pelos métodos da emergia e da exergia. A aplicação do método EDIP foi iniciada durante o estágio realizado na Dinamarca, assim como foram definidas as condições ideais para utilizar a emergia e a exergia.

As etapas do ciclo de vida avaliadas incluem o preparo do solo e o cultivo agrícola da cana-de-açúcar, o transporte interno, o processo industrial, a reutilização dos resíduos e dos efluentes industriais, a geração de vapor e de energia elétrica, a armazenagem e distribuição, assim como a utilização do álcool etílico hidratado combustível. 


\section{Capítulo 2. Revisão Bibliográfica}

\subsection{Gestão ambiental do processo ao produto}

A gestão ambiental, segundo Tolba (1982), não deve ser entendida como o gerenciamento do meio ambiente, mas como o gerenciamento adequado das atividades humanas, para estas não comprometerem a qualidade do meio pelo uso acima da capacidade de suporte ${ }^{3}$ deste. Portanto, o maior objetivo da gestão ambiental é buscar a realização das necessidades humanas, considerando os potenciais e as restrições dos sistemas ambientais, como um instrumento para a sustentabilidade.

Sustentabilidade é um relacionamento entre sistemas econômicos
dinâmicos e sistemas ecológicos maiores e também dinâmicos,
embora de mudança mais lenta, em que: a) a vida humana pode
continuar indefinidamente; b) os indivíduos podem prosperar; c) as
culturas humanas podem desenvolver-se; mas em que d) os
resultados das atividades humanas obedecem a limites para não
destruir a diversidade, a complexidade e a função do sistema
ecológico de apoio à vida. (CONSTANZA,1991, p. $85^{4}$ apud SACHS,
1993).

A União Internacional para a Conservação da Natureza e dos Recursos Naturais (IUCN) (1991) considera desenvolvimento sustentável o processo que melhora as condições de vida das comunidades humanas e, ao mesmo tempo, respeita os limites da capacidade de suporte dos ecossistemas.

\footnotetext{
${ }^{3}$ Capacidade de suporte é entendido como a capacidade do sistema natural assimilar as alterações a ele imposto dentro dos limites mínimos e máximos de tolerância explicados em ODUM (1988), a fim de que possa, por meio da sua resiliência, retornar à sua condição original de equilíbrio.

${ }^{4}$ CONSTANZA, R. (ed.). Ecological Economics: the science and management of sustainability. Nova York, Columbia University Press.
} 
Para Manzini e Vezzoli (2002), as atividades econômicas podem ser consideradas sustentáveis, se apresentarem os seguintes requisitos:

- basear-se em recursos naturais renováveis com otimização do uso;

- não gerar resíduos acima da capacidade do ambiente em "renaturalizá-los";

- as sociedades "ricas" diminuírem sua exploração ambiental para que as "pobres" possam usufruir do mínimo necessário.

A sustentabilidade, segundo Sachs (1993), apresenta cinco dimensões que devem ser consideradas em todo planejamento: social, econômica, ecológica, espacial e cultural.

Souza (2004) indica, ainda, que a sustentabilidade pode ser alcançada a partir de três premissas: o tempo, o espaço e a participação da sociedade. $O$ fator temporal engloba as conseqüências à presente e às futuras gerações, podendo ser definido pelas análises de curto, médio e longo prazo. A questão espacial baseia-se na necessidade de se conhecerem as especificidades locais, de acordo com os aspectos físicos, químicos, biológicos, sociais, econômicos e culturais da região de estudo. Já a participação da sociedade junto ao processo decisório configura-se como uma prática inerente ao processo democrático, de modo a legitimar os aspectos técnicos abordados.

Assim, para que a gestão ambiental seja um real instrumento de sustentabilidade, Souza (1993) indica que a gestão deve ser entendida como um conjunto de procedimentos que busquem a harmonia entre desenvolvimento e qualidade ambiental, a partir das necessidades identificadas pela sociedade civil ou pelo Estado e representadas na legislação ordinária, na política ambiental e, também, na participação da sociedade.

Para Souza (1996), as etapas que devem constar da prática da gestão ambiental são a caracterização ambiental, a caracterização do empreendimento, a análise ambiental, as medidas mitigadoras, o monitoramento e a retroalimentação das informações para o sistema de gestão, como mostra a figura 2. 


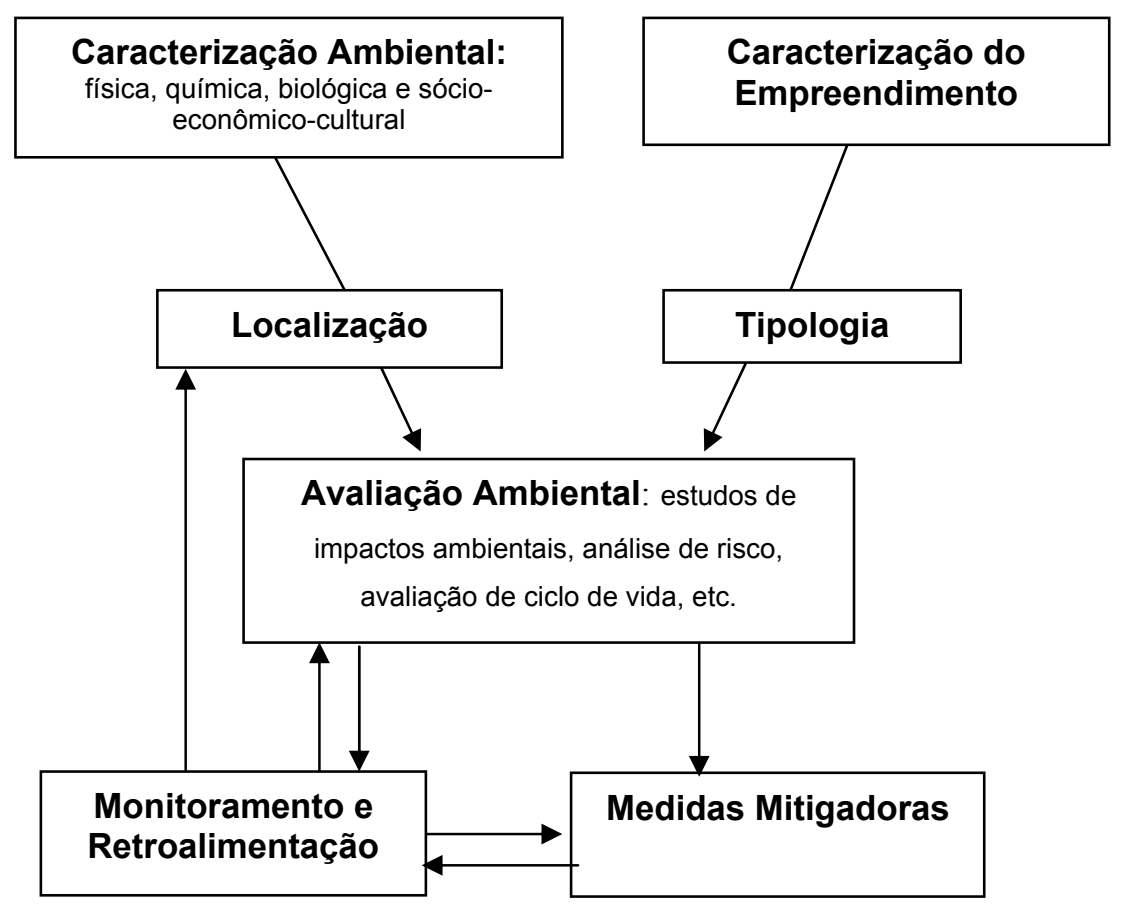

Figura 2 - Sistema de Gestão Ambiental

$$
\text { Fonte - SOUZA (1996) }
$$

Cabe à caracterização ambiental determinar as vocações e as restrições dos fatores ambientais da região em análise, permitindo, assim, que as atividades humanas possam ser localizadas de forma que as potencialidades do meio sejam exploradas, respeitando-se sua capacidade de suporte. Além disso, a caracterização ambiental fornece, segundo Ab'saber (1998), informações sobre a área de influência dos possíveis impactos, o que orientará a etapa de monitoramento.

Concomitante à caracterização do meio, deve-se realizar a caracterização do empreendimento, por meio de um estudo, abordando os aspectos técnicos, como os insumos, a matéria-prima, o processo produtivo, os efluentes, os resíduos, as emissões, entre outros. Esta etapa resulta na tipologia, a qual deve compreender, segundo Souza (2000), as etapas do projeto, a implantação, a operação e a desativação do empreendimento.

O cruzamento das características do empreendimento com as características do meio fornecerá subsídios para se analisarem os impactos ambientais decorrentes da atividade. Esta fase é identificada como avaliação ambiental e deve garantir a viabilidade ambiental do empreendimento. 
Algumas ferramentas para a realização desta etapa são os estudos prévios de impactos ambientais, a análise de riscos e a avaliação do ciclo de vida.

Para Alvarenga (1997), esta etapa compreende a alocação dos atributos de restrições e de potencialidades ambientais, a considerar de acordo com a ordem estabelecida das condicionantes determinadas no processo de caracterização. Com isso, cria-se a condição de se determinar a localização mais adequada para determinado empreendimento, assim como as áreas que devem ser protegidas.

As medidas mitigadoras, segundo Souza (2000), podem ser preventivas e, portanto, incluem as técnicas de redução de efluentes, resíduos e emissões na fonte geradora, assim como o projeto de produtos com considerações ambientais - ecodesign ${ }^{5}$.

O monitoramento e a retroalimentação das informações para o sistema de gestão são fundamentais na obtenção da melhoria contínua do processo e da garantia da eficácia das medidas implementadas. O monitoramento pode ser realizado com a instrumentação nos locais das atividades, assim como por meio de monitoramento à distância, com o uso do sensoriamento remoto e de imagens de satélite de alta resolução. Esta tecnologia aplicada às diversas fases do produto é conhecida como georastreabilidade, que é uma forma de monitorar as atividades de produção por meio de geotecnologias.

Manzini e Vezzoli (2002) citam que o impacto provocado no ambiente pelas atividades humanas depende de três fatores: a população, a procura do bem estar humano e a ecoeficiência das tecnologias aplicadas. A ecoeficiência pode ser entendida como a otimização do processo produtivo ou do ciclo de vida do produto conciliada com a minimização de impactos adversos ao ambiente e ao ser humano. O World Business Council for Sustainable Development (WBCSD) criou o termo ecoeficiência em 1992 e o define:

as being achieved by the delivery of competitively priced goods and services that satisfy human needs and bring quality of life, while progressively reducing ecological impacts and resource

\footnotetext{
${ }^{5}$ Ecodesign é o desenvolvimento do produto que incorpora no projeto as questões ambientais a fim de reduzir os impactos ambientais deste ao longo de seu ciclo de vida.
} 
intensity throughout the life cycle, to a level at least in line with the Earth's estimated carrying capacity (WBCSD, 2004).

Dessa forma, o sistema de gestão ambiental visa à conservação e à melhoria do ambiente, assim como à proteção da saúde humana. Tais objetivos devem englobar os requisitos e as metas das atividades humanas, inclusas as empresariais, a fim de se obter a sustentabilidade.

Inicialmente, por meados das décadas de 1970 e 1980, as empresas utilizavam, como primeira solução aos problemas ambientais, a prática do tratamento de resíduos, efluentes ou emissões, denominadas tecnologias de "fim de tubo". Atualmente, ainda há muitas empresas no Brasil que utilizam somente esta estratégia para resolver seus desafios ambientais. Contudo outras estratégias inovadoras surgiram.

Após essas duas décadas, motivadas por diversas crises de escassez de recursos naturais, como de energia e água, as empresas começaram a se preocupar com a gestão dos processos produtivos, tendo em vista a redução das perdas e dos desperdícios na fonte geradora.

Com tal enfoque, surge o conceito de clean production (produção limpa), o qual foi adotado por um grupo de trabalho da United Nations Environment Programme (UNEP) e citado por Baas et al. (1990) ${ }^{6}$ apud Jackson (1993), como o conceito de produção que incorpora a prevenção ou a minimização de riscos à saúde humana e ao meio ambiente, a curto e longo prazo.

As técnicas e tecnologias para uma produção limpa envolvem, segundo United Nations Industrial Development Organization (UNIDO) (1997), reduções dos níveis de perdas, de desperdícios, de resíduos e de emissões. Implementações corretas fornecem às empresas soluções práticas e efetivas de melhorias ambientais e reduções de custos, não se limitando apenas à adequação às legislações ambientais.

Jackson (1993) adota como definição de produção limpa uma aproximação operacional para o desenvolvimento de sistemas de produção e consumo que incorpore uma postura preventiva para a proteção do meio

${ }^{6}$ BAAS, L.; HOFMAN, H.; HUISINGH, J.; KOPPERT, P. NEUMANN, F. (1990). Protection of the North SEA: Time for Clean Production, Erasmus Centre for Environmental Studies, Erasmus University, Rotterdam. 
ambiente. As premissas desse conceito são: a precaução, a prevenção e a integração de toda a cadeia produtiva. A partir destas considerações, as duas práticas principais para a produção limpa são:

1. a redução do fluxo de materiais do processo, ciclo ou atividade, ou a melhoria na eficiência desses processos;

2. a substituição de materiais, produtos ou serviços perigosos por outros de menores impactos.

Algumas formas de se atingir a produção limpa podem ser citadas pelas técnicas de minimização de materiais, de perdas, de desperdícios e de efluentes (incluindo as emissões e resíduos), visualizadas na figura 3.

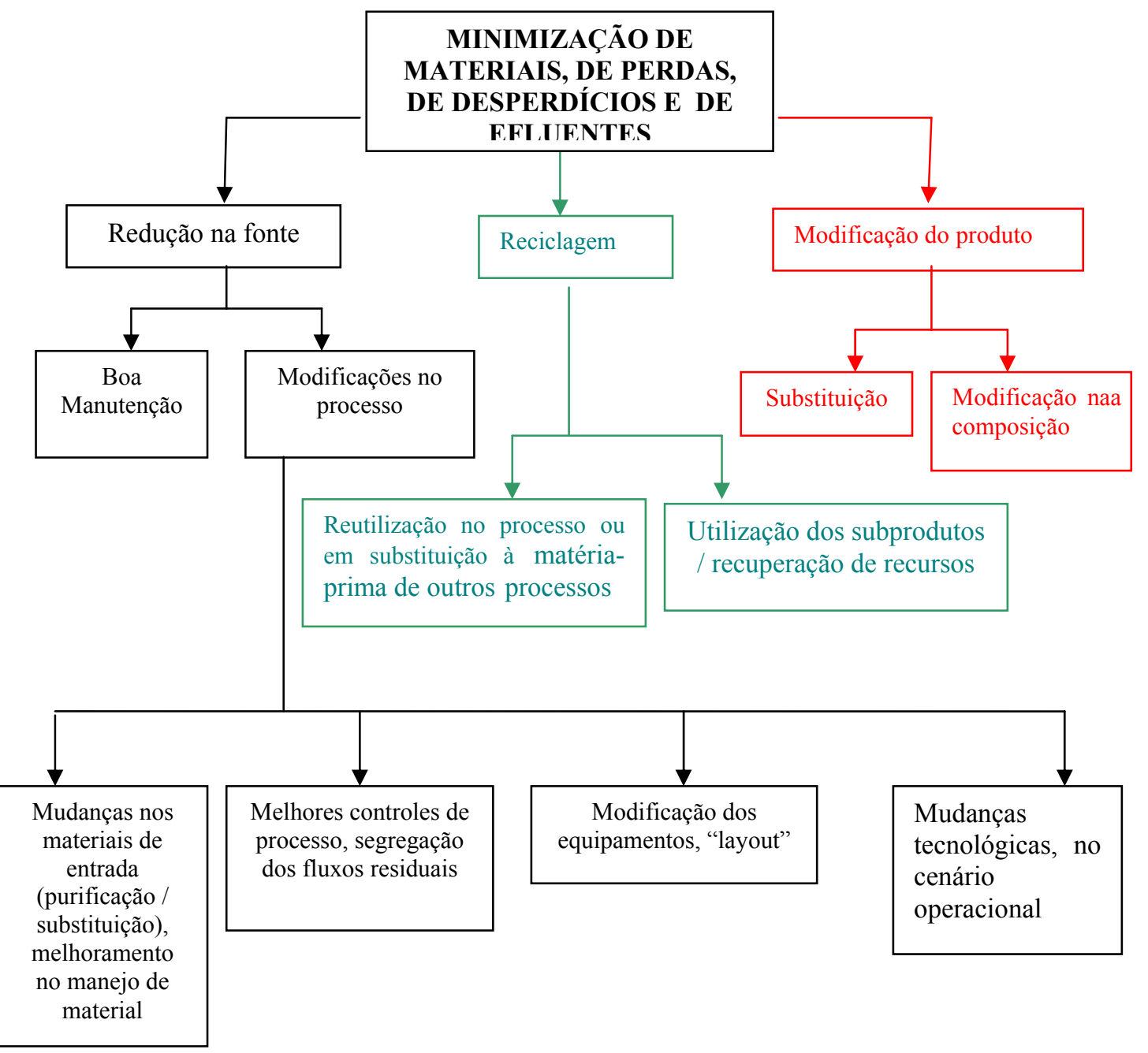

Figura 3 - Visão geral das técnicas de minimização dos efluentes

Fonte - Adaptado de UNIDO (1997) e FREEMAN (1990) 
De acordo com UNIDO (1997), a diminuição de materiais, de perdas, de desperdícios, de efluentes, de resíduos e de emissões são alguns dos objetivos da produção limpa. Esses podem ser alcançados a partir das 8 técnicas mostradas na figura 3 e exemplificadas a seguir:

1) Manutenção adequada:

- prevenção de vazamentos, perdas, derramamentos;

- calendário de manutenção preventiva;

- inspeção freqüente dos equipamentos;

- treinamento do pessoal.

\section{2) Realizar substituições:}

- por material menos tóxico;

- por material renovável;

- por material com maior ciclo de vida.

\section{3) Melhoria no controle do processo:}

- mudanças nos procedimentos de trabalho;

- instruções de utilização das máquinas;

- monitoramento dos dados do processo para facilitar a melhoria da eficiência e reduzir as perdas e emissões.

4) Mudanças no equipamento:

- mudanças nos equipamentos de produção e nos auxiliares, como a adição de uma divisão de medidas e de controle, para melhorar a eficiência e diminuir as taxas de perdas e emissões.

\section{5) Mudanças na tecnologia:}

- utilização de tecnologias menos poluente;

- mudança no fluxograma do processo, a fim de diminuir a cadeia produtiva. 


\section{6) Reciclagem / Reuso:}

- realizar a reutilização das perdas geradas para serem utilizadas no próprio processo, para outras aplicações na companhia ou para outras empresas.

\section{7) Produzir o máximo que pode ser utilizado:}

- investigar novos usos para utilização e transformação das perdas geradas em materiais que podem ter aplicações.

\section{8) Reformulação ou modificação do produto:}

- mudanças no produto com a finalidade de minimizar os impactos durante a produção, o uso, a reciclagem ou a disposição final.

De acordo com Freeman (1990), para que as técnicas de prevenção contra a poluição sejam cada vez mais eficazes e economicamente viáveis, elas devem ser utilizadas em conjunto, podendo ser aplicadas em muitos estágios do processo industrial. Tais técnicas também devem ser aplicadas em consonância com estudos mais abrangentes de todo o ciclo de vida do produto, como a ACV, a fim de se obter o resultado mais eficaz para a redução de impactos ambientais negativos de um produto, processo ou atividade.

Nessa linha, Mcintyre et al. (1998) consideram que os impactos ambientais não devem ser considerados de forma pontual, em uma determinada etapa do processo, mas por meio de uma avaliação global de toda a cadeia do produto.

Alting e Legarth (1995) consideram, ainda, que a manufatura está se tornando cada vez mais responsável pela performance ambiental do produto, a partir de seu ciclo de vida. Tal ciclo é composto de estágios consecutivos e interligados, desde a extração da matéria-prima e as etapas da prémanufatura, à manufatura, ao uso, ao transporte, à reciclagem e à disposição final.

Assim, segundo Alting e Legarth (1995), para incorporar as questões e os parâmetros ambientais ao ciclo de vida, durante o desenvolvimento do produto, surge a Engenharia de Ciclo de Vida (ECV). Seu escopo é 
abrangente e envolve desde a engenharia de manufatura ${ }^{7}$, a escolha dos materiais, os fornecedores, o uso, o pós uso do produto, assim como todas as etapas que possam incorporar a questão ambiental no desenvolvimento de um produto durante todo seu ciclo de vida.

Ainda, segundo Alting e Legarth (1995), a ECV é definida como a arte de projetar o ciclo de vida do produto por meio de escolhas sobre a sua concepção, a sua estrutura, os seus materiais e os seus processos; já a ACV é a ferramenta que visualiza as conseqüências ambientais e recursivas dessas escolhas.

Segundo Barbieri (1997), tais ferramentas devem servir para que o produto seja gerado de forma ambientalmente adequada e para que, durante a fase de concepção do produto, se tenha em vista, também, a facilidade de desmontagem, de reutilização, de reciclagem ou de remanufatura após seu uso.

Wenzel et al. (1994) consideram que a habilidade da ACV em medir o impacto ambiental de um produto pelo seu ciclo de vida a torna a única ferramenta holística para avaliar as consequências das escolhas, feitas durante o desenvolvimento do produto, ao meio ambiente e aos recursos.

Segundo Society of Environmental Toxicology and Environmental (SETAC) (1991), a ACV é um processo objetivo para avaliar cargas ou impactos ambientais associados a produtos, a processos ou a atividades, por meio da identificação e da quantificação de energia e de materiais usados, assim como dos resíduos emitidos no meio ambiente. O objetivo maior de avaliar o impacto desses usos é indicar oportunidades para conferir melhoramentos ambientais para todo o ciclo de vida do produto, do processo ou da atividade.

Para Udo de Haes et al. (2002), a ACV é o processo de avaliação dos efeitos que um produto, um processo ou uma atividade (ou a função que são

\footnotetext{
${ }^{7}$ A engenharia de manufatura "engloba todas as fases do processo produtivo, desde a etapa do projeto do produto ao projeto e planejamento dos processos a serem utilizados para a fabricação do produto até a execução, distribuição e disposição final do mesmo" (MAGNANI, 2000).
} 
projetados para desenvolver) apresentam sobre o ambiente, considerando todo o ciclo de vida.

Barnthouse et al. (1997) advertem que os usuários da ACV devem compreender que ela é uma análise específica, com características próprias, distintas dos métodos comuns de avaliação ambiental. A ACV avalia o comprometimento ambiental de um produto, um processo ou uma atividade, a partir dos fluxos de entrada e da saída dos materiais e da energia de todo o ciclo de vida.

Como o estudo de ACV tem por base o ciclo dos materiais e da energia, ele pode subsidiar soluções que se aproximem da base conceitual de como os processos naturais ocorrem. Dessa confluência, surge a ecologia industrial, a qual, segundo Manzini e Vezzoli (2002), é entendida como um sistema de produção e de consumo, organizado de maneira a aproximar-se do funcionamento do sistema natural, combinando os tecnociclos aos biociclos.

Segundo a definição da ISO (1997) e ABNT (2001), a ACV é uma técnica de compilação dos aspectos ambientais ${ }^{8}$ e de avaliação dos impactos ambientais potenciais ${ }^{9}$ associados a um produto ou serviço no decorrer de seu ciclo de vida (desde a aquisição da matéria-prima, à produção, ao uso e à disposição) mediante:

- a compilação de um inventário de entradas e de saídas pertinentes a um sistema de produto ${ }^{10}$;

- a avaliação dos impactos ambientais potenciais associados a essas entradas e saídas;

- a interpretação dos resultados das fases de análise de inventário e de avaliação de impactos em relação aos objetivos dos estudos.

\footnotetext{
${ }^{8}$ Aspecto ambiental no contexto de sistemas produtivos é o elemento das atividades, produtos ou serviços de uma organização que pode interagir com o meio ambiente. Um aspecto ambiental significativo é aquele que tem ou pode ter um impacto ambiental significativo (ABNT, 1996)

${ }^{9}$ Os “impactos ambientais potenciais"são um subconjunto dos “impactos ambientais" referidos em ABNT (1996), resultante do uso da unidade funcional de cálculo. Os "impactos ambientais potenciais" são expressões relativas, pois estão relacionados à unidade funcional de um sistema de produto (ABNT, 2004b).

${ }^{10}$ Sistema de produto é o conjunto de unidades de processo, conectadas material e energeticamente, que realiza uma ou mais funções definidas (ABNT, 2001).
} 
Segundo ISO(1997), ABNT(2001), ABNT(2004a) e ABNT(2004b), as aplicações que a ACV pode oferecer são:

- na identificação de oportunidades para melhorar os aspectos ambientais dos produtos em vários pontos de seu ciclo de vida;

- na tomada de decisões na indústria, em organizações governamentais ou não-governamentais (por exemplo, planejamento estratégico, definição de prioridades, projeto ou reprojeto de produtos ou serviços);

- na seleção de indicadores pertinentes de desempenho ambiental, incluindo técnicas de medição;

- no marketing, por exemplo, uma declaração ambiental, um programa de rotulagem ecológica ou uma declaração ambiental de produto;

- no auxílio às organizações para obterem uma visão sistemática de sistemas de produtos interconectados;

- na formulação do objetivo e do escopo de um estudo, na definição e na modelagem dos sistemas a analisar, na coleta dos dados, na análise e no relatório dos resultados;

- no estabelecimento de um nível básico de desempenho ambiental para um determinado sistema de produto pela quantificação do uso de matérias-primas, dos fluxos de energia e das emissões para a atmosfera, a água e o solo (dados ambientais de entrada e de saída) associados ao sistema, tanto para o sistema completo quanto para os processos elementares que o compõem;

- na identificação daqueles processos, em um sistema de produto, onde ocorrem as maiores utilizações de fluxos de energia e de matérias-primas e emissões, com vistas a promover as melhorias planejadas;

- no fornecimento de dados para a utilização subseqüente, como auxílio à definição de critérios de rotulagem ambiental; 
- no estabelecimento de opções de política, por exemplo, relativas a processos de aquisição de bens e materiais;

- na identificação de oportunidades e no auxílio em sua priorização para a melhoria do projeto e do sistema do produto;

- nas comparações relativas entre sistemas de produtos, com base em indicadores de categoria selecionados;

- na indicação de questões ambientais para as quais outras técnicas podem fornecer dados ambientais complementares e informações úteis para a tomada de decisão.

Além disso, a ACV pode contribuir para:

- subsidiar a tomada de decisão para comparar produtos funcionalmente equivalentes e diferentes opções de processos;

- subsidiar ações que visem à otimização de processos e ao uso racional de materiais, de modo a reduzir os custos e os impactos ambientais dos mesmos;

- fornecer informações para processos de auditorias;

- subsidiar as estratégias relacionadas com desenvolvimento e com projetos de novos produtos ambientalmente mais adequados (ecodesign);

- fornecer informações para consumidores sobre as características ambientais de produtos;

- fornecer informações para políticas de regulamentos e leis quanto à restrição de uso de materiais, apoiando as políticas voltadas aos produtos;

- reunir informações de sistemas de produtos para a formação de bancos de dados;

- avaliar efeitos sobre a disponibilidade de recursos e de técnicas de gestão de resíduos;

- ajudar o desenvolvimento de políticas de longo prazo, com relação ao uso de materiais, à conservação de recursos e à 
redução de impactos ambientais durante o ciclo de vida dos produtos;

- avaliar, quantitativamente, os impactos ambientais relacionados aos fluxos do ciclo de vida de um produto;

- segundo Alting e Legarth (1995), servir como base para a conceituação, a estrutura e a definição de materiais e de processos a utilizar na manufatura.

Assim, a ACV pode ser indicada como um instrumento integrativo, científico e quantitativo, primariamente de gestão ambiental direcionada ao produto, cobrindo todos os estágios do ciclo de vida e de seus aspectos e impactos ambientais.

Relacionando a gestão ambiental, com base na figura 2, à gestão ambiental do produto, a etapa de caracterização da atividade pode ser realizada pela análise de inventário do ciclo de vida do produto, a qual inclui a obtenção e o tratamento dos dados relacionados a todas as atividades do ciclo de vida. A análise ambiental pode ser indicada pela avaliação dos impactos do ciclo de vida do produto. A mitigação dos impactos pode ser relacionada com as técnicas de produção limpa indicadas para cada atividade do ciclo e com o ecodesign. Completando, indica-se a análise dos locais mais adequados, ambientalmente, para a realização das atividades do ciclo, com base nos impactos das atividades do ciclo de vida e nas potencialidades e restrições do meio.

Em vista disso, as empresas devem escolher, já durante a fase de desenvolvimento do projeto das atividades e do produto, a forma com menor impacto ambiental, assim como os locais ambientalmente mais adequados. Tal consideração deve englobar a variável ambiental em todo o ciclo de vida, desde a extração da matéria-prima até a reutilização ou a reciclagem do produto e a desativação da atividade.

Um das aplicações da gestão ambiental do produto no planejamento empresarial é naquilo que Cristopher (1993) denomina supply chains (cadeias de suprimentos), nas quais a análise ambiental deve ser incorporada em toda a cadeia de fornecedores da empresa. 
Desse modo, surge a green supply chain, a qual busca a qualidade ambiental de toda a cadeia de suprimentos, considerando sua logística reversa, determinada pela logística do pós-uso, a fim do produto ser destinado à reciclagem, à remanufatura, à reutilização ou à disposição final adequada.

Com a green supply chain, o supply chain management, definido por Slack et al. (1998) como a gestão da cadeia de suprimentos, desde as matérias-primas e a manufatura, até a distribuição aos clientes finais, tem seu conceito ampliado. A partir da integração dos aspectos ambientais, essa gestão incorpora o conceito de ciclo de vida do produto e é aplicada também após o uso, por meio da logística reversa.

A green supply chain faz parte da supply strategy, definida por Harland (1999) como uma abordagem mais ampla da cadeia de suprimentos, e que integra diversos campos do conhecimento e conceitos de uma forma holística, dentro de uma perspectiva estratégica de administração de operações, estendendo-se além das fronteiras da organização.

A green supply chain, juntamente com a ACV, passam a ser instrumentos de gestão ambiental de produtos e componentes da estratégia empresarial. Essas duas ferramentas são importantes na busca do menor impacto ambiental relacionado ao ciclo de vida de um determinado bem de consumo.

Além disso, nessa visão de adequação ambiental de toda cadeia produtiva, Harland (1999) sugere o conceito de value creating network, como uma cooperação produtiva ao longo de uma cadeia de adição de valor (value added chain). Neste caso, a forma de criar uma vantagem competitiva no mercado é por meio da realização e da entrega de bens e de serviços com qualidade ambiental. Esta comprovação poderá ser realizada pela rotulagem de terceira parte, que está sendo desenvolvida pela ISO, com base na ACV do produto.

Portanto, atualmente, a inserção da variável ambiental no planejamento empresarial transcende a necessidade gerada pela responsabilização legal dos produtores, e se torna uma estratégia administrativa de gestão integrada, de modo a obter-se a otimização da manufatura, a redução dos custos, a 
racionalização dos recursos, servindo como instrumento de conquista de novos mercados. Para isso, a gestão não pode se limitar somente ao processo produtivo, mas sim a todo o ciclo de vida do produto.

\subsection{O ciclo de vida do álcool etílico hidratado combustível}

Segundo Almeida [197-?], o álcool é produto da destilação de líquidos fermentados, como os vinhos. O álcool etílico ou etanol é uma substância orgânica ternária, constituída por carbono $(C)$, hidrogênio $(H)$ e oxigênio $(O)$, cuja fórmula molecular é $\mathrm{C}_{2} \mathrm{H}_{6} \mathrm{O}$.

Os álcoois são neutros, derivados dos hidrocarbonetos (compostos formados por $\mathrm{C}$ e $\mathrm{H}$ ) pela substituição de um ou mais átomos de hidrogênio por um ou mais hidroxilas $\left(\mathrm{OH}^{-}\right)$. O etanol é classificado como álcool primário, pois contém o hidroxilo ligado a um átomo de carbono primário, isto é, o átomo de carbono que se acha unido ao grupo hidroxilo está ligado somente a um átomo de carbono. É um álcool saturado, com ligações simples entre os dois carbonos.

De forma geral, as etapas do seu ciclo de vida podem ser resumidas em: extração da matéria-prima, produção, reciclagem, armazenagem, distribuição e utilização. Para o álcool combustível advindo da cana-de-açúcar, a extração da matéria-prima corresponde às atividades agrícolas do cultivo da cana-deaçúcar; a produção, a fase de transformação industrial, desde a entrada da cana na usina até a produção do álcool combustível, incluindo a geração de energia elétrica e o vapor; a reciclagem que é realizada por meio da fertirrigação da vinhaça; a armazenagem nos tanques de álcool; a distribuição, pelo transporte do álcool até os postos revendedores e a utilização, pela combustão do etanol usado como combustível em veículos automotores.

A fase agrícola do processo canavieiro, admitindo que a área já tenha sido desmatada e que já esteja sendo utilizada para fins agrícolas, inicia-se, de acordo com o Instituto Agronômico de Campinas (IAC) (1994), pelas operações de limpeza do terreno, de nivelamento de solo, de estudos de sua qualidade, de aração e de gradagem. 
Após essas atividades, inicia-se o preparo do solo, que, segundo Castro (1985) e Ometto, D. (2000), pode ser definido como uma série de operações que têm por finalidade fornecer as melhores condições físico-químicobiológicas ao solo para a germinação das sementes ou o brotamento dos tubérculos.

A conservação do solo faz parte de algumas técnicas do preparo, tais como: a incorporação da matéria orgânica, as curvas de nível, os terraços e a subsolagem, ou seja, a eliminação das camadas compactas para o aumento da infiltração de água no solo.

De acordo com Ometto, A. (2000), o preparo periódico do solo em canade-açúcar ocorre para o plantio da cana planta. Após o primeiro corte, ocorre o preparo para a cana soca, o qual se repete, geralmente, por cinco cortes e finalmente, o ciclo se completa com a renovação do canavial, a qual ocorre pelo replantio.

A renovação do canavial pode ser realizada pelo modo mecânico ou pelo químico. Para o modo mecânico, Ometto, D. (2000) enumera as seguintes operações: aração e gradagem ou gradagem pesada, subsolagem, sulcamento e adubação.

Além da erradicação da soqueira de modo mecânico, pode-se utilizar, também o modo químico, em conjunto com as operações de preparo de solo, como se observa na figura 4.

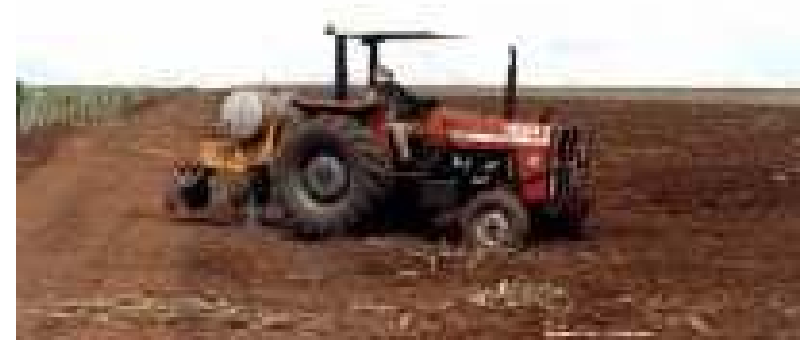

Figura 4 - Aplicação de herbicida com operação de preparo do solo Fonte - OMETTO, A (2000) 
Ainda para a renovação do canavial, o preparo do solo de modo convencional, segundo Freitas (1987), pode ser ordenado nas seguintes operações:

1.“limpeza, enleiramento e queima da palha;

2. calagem: sempre que as quantidades de cálcio e/ou magnésio trocáveis do solo estiverem em níveis insuficientes, ou quando o solo apresentar altos teores de alumínio tóxico;

3. grade pesada para erradicação da soqueira;

4. operações de conservação de solo (curvas de nível, terraceamento);

5. gradagens subseqüentes;

6. sistematização;

7. subsolagem com aletas (em áreas que exijam esta operação);

8. gradeação pesada;

9. gradagem leve de pré-plantio."

Segundo Castro (1985), o preparo convencional do solo antes do plantio pode, também, ser dividido em primário: aração, desmatamento e operações com rolo faca; e secundário: nivelamento do terreno, destorroamento, incorporação de herbicidas, eliminação de ervas invasoras com o uso de gradagem e/ou enxada rotativa.

De acordo com Ometto, A. (2000), a operação de plantio pode ser manual ou mecanizada, feita pelo modo direto ou convencional. No método de plantio direto, o sulco é feito por meio de um sulcador que atua sobre a palhada remanescente, enquanto, no convencional, o terreno é preparado por operações de aração e gradagem, seguidas do sulcador no solo sem palha. $O$ sulco é um canal de aproximadamente 25 a $30 \mathrm{~cm}$ de profundidade, no qual a muda de cana-de-açúcar é colocada. Quando o solo é impermeável e muito compactado, utiliza-se a subsolagem para romper esse horizonte de impedimento e para facilitar o desenvolvimento e a penetração das raízes no solo. 
O plantio é realizado, prioritariamente, de modo manual, com o auxílio de um caminhão, o qual carrega a cana; os funcionários arremessam-na no sulco enquanto outros a picam em toletes, como mostra a figura 5. Este modo, associado com o preparo convencional de erradicação da soqueira, mecânico e químico, são os mais usuais na cultura canavieira .

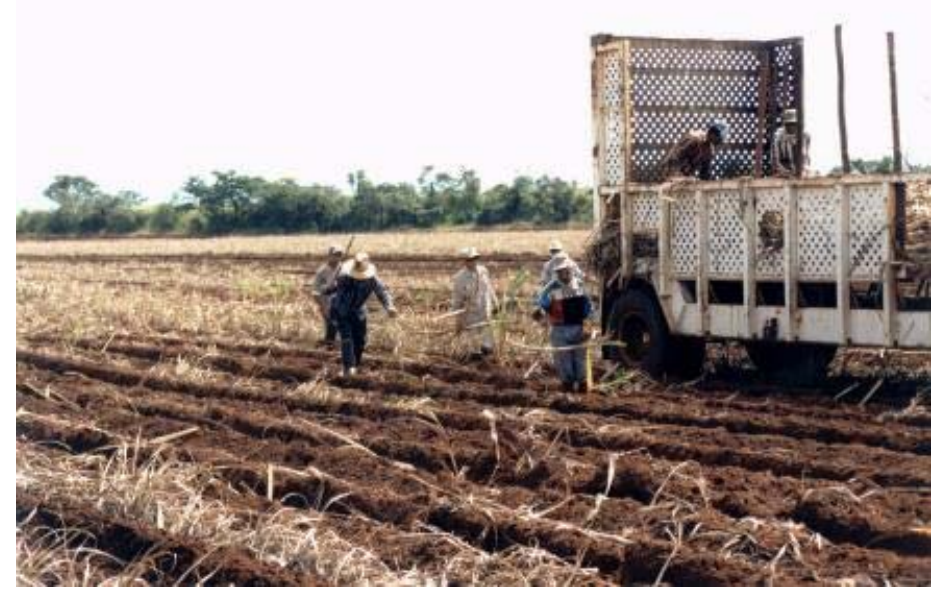

Figura 5 - Plantio manual

Fonte - OMETTO, A. (2000)

Após o plantio, iniciam-se os tratos culturais que, segundo Corbini (1987), são práticas agrícolas com as seguintes finalidades:

- preservar ou restaurar as propriedades físicas e químicas do solo;

- eliminar ou reduzir a concorrência das plantas invasoras;

- conservar o sistema de controle de erosão;

- controlar pragas ou doenças, eventualmente.

De acordo com Corbini (1987), as operações de controle das ervas concorrentes podem ser:

- preventivas: como levantamento das infestações para a identificação precoce de pequenos focos;

- culturais: pela cobertura total do solo e por práticas de rotação com adubos verdes;

- mecânico: podendo ser manual, com a utilização da enxada; animal, no qual os cultivadores são tracionados por animais e mecanizada por tratores; 
- cultivo químico: herbicidas, como mostra a figura 6.

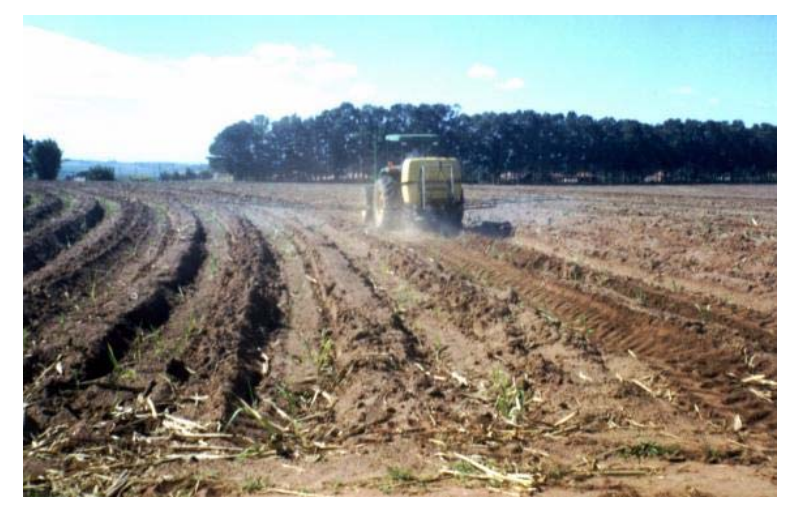

Figura 6 - Aplicação de herbicida com tratores

Fonte - OMETTO, A. (2000)

Segundo o IAC (1994), os tratos culturais incluem a aplicação de agrotóxicos e, quando necessário, a adubação. De acordo com Ometto, A. (2000), os principais agrotóxicos aplicados na lavoura da cana-de-açúcar são:

- Aldrin: para Mello (1997), baseado em Ottaway ${ }^{11}$ (1982), é um organoclorado utilizado para combater nematóides e insetos. A utilização de organo-clorados é proibida em diversos países pelo seu poder residual e acumulativo na cadeia alimentar. O tempo para o desaparecimento de $95 \%$ da quantidade aplicada varia, de acordo com Rüegg et al. (1991), de 5 a 7 anos, podendo o agrotóxico permanecer no solo por 10 a 12 anos;

- Ametrina: herbicida com nomes comerciais de Gesapax, Herbipax e Metrimex;

- Atrazina: herbicida para controlar gramíneas anuais e latifoliadas;

- Clorpirifuos: inseticida considerado tóxico;

- 2,4 D: segundo Arevalo (1980), herbicida do grupo químico dos fenoxis;

- Diflubenzuron: inseticida de baixa toxicidade;

- Diuron: segundo Arevalo (1980), herbicida do grupo da uréia, de baixa toxicidade;

- Finitrotin: inseticida de baixa toxicidade;

${ }^{11}$ OTTAWAY, J. H. (1982). Bioquímica da poluição. São Paulo, EPU-EDUSP 
- Hexazinone: herbicida conhecido comercialmente como Velar K;

- Paration metil: componente ativo de alguns pesticidas organo-fosforados. Sua ação baseia-se em matar os insetos provocando o bloqueio dos impulsos nervosos. É banido dos EUA, pela Agência de Proteção Ambiental norte-americana (EPA), segundo a Folha de São Paulo (1999);

- Glifosato: comercialmente conhecido como Roundup;

- Simazina: herbicida com nomes comerciais de Topeze e Simetrex SC;

- Tebuthiuron: segundo Victoria (1993), constitui um herbicida de nome comercial Perflan e Combine;

- Telrithiuron;

- Velpark.

Após as aplicações de herbicidas, a próxima etapa do ciclo de vida do álcool, ainda nas operações agrícolas, é a fase da colheita, na qual se utiliza a prática da queima da palha da cana-de-açúcar, prévia ao corte, em $75 \%$ das áreas com cana no Estado de São Paulo, segundo Macedo et al. (2004).

Silva (1998) explica o processo da queima da palhada da cana-deaçúcar, ilustrada na figura 7 , em três fases:

a) Ignição: o início do processo, na presença de oxigênio e baixas temperaturas. Esta fase é rápida e apresenta, ainda, baixa concentração de poluentes;

b) Combustão incompleta: atinge altas temperaturas e forma gases tóxicos, como $\mathrm{CO}_{2}$, NOx (óxido de nitrogênio) e SOx (óxido de enxofre), entre outros.

c) Resfriamento: a última etapa da queima, caracterizada pela diminuição da temperatura e pela liberação de materiais particulados, hidrocarbonetos policíclicos aromáticos (HPAs) e outras substâncias orgânicas provenientes dessa combustão incompleta. 


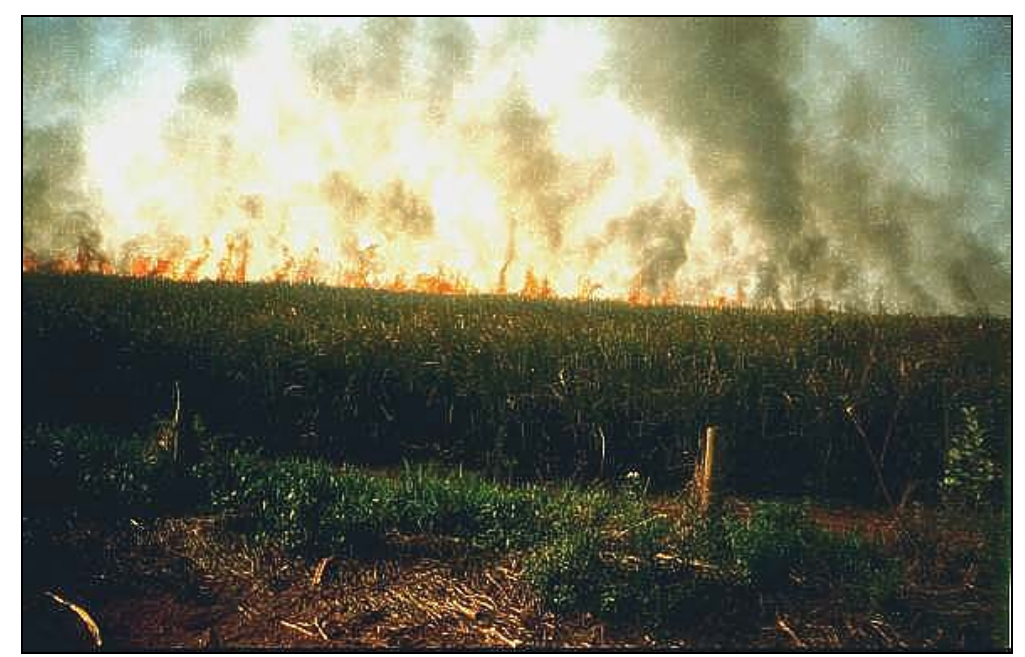

Figura 7 - Queima da palhada da cana-de-açúcar

Fonte - OMETTO, A. (2000)

A etapa da fabricação do álcool inicia-se com a entrada da cana-deaçúcar na usina, descarregada por caminhões, em esteiras que as conduzem às etapas do processo industrial.

Segundo Ometto, A. (2000), logo no início do processo industrial, a cana já é lavada com água, como mostra a figura 8, para a retirada do material incorporado ao colmo durante o corte e o transporte do campo à usina, surgindo o primeiro efluente: a água de lavagem de cana. Algumas usinas descartam esta operação, principalmente quando é utilizado o corte da cana crua, pois, como o colmo não exsuda, não retém tanta sujeira como o colmo que sofre exsudação com a queimada, o qual, ainda, perde sacarose.

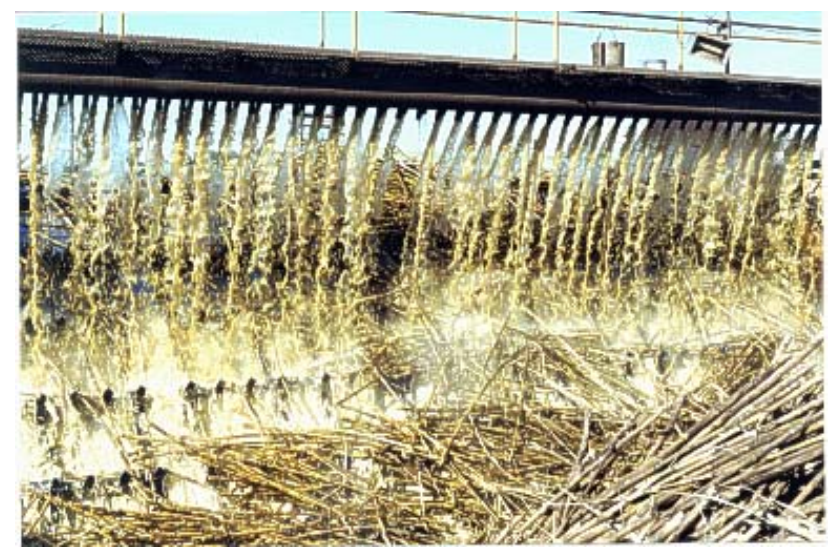

Figura 8 - Lavagem da cana-de-açúcar

Fonte - OMETTO, A. (2000) 
A eliminação dessa operação contribui para a redução de custos ambientais e econômicos pela não-utilização excessiva de água, já que, segundo Braile e Cavalcanti (1979), essa etapa do processamento industrial consome, em média, 3 a $7 \mathrm{~m}^{3}$ de água por tonelada de cana.

Logo após a lavagem, a matéria-prima do processo industrial, a cana-deaçúcar, é submetida a uma série de facas e desfibradores para aumentar a eficiência de extração do caldo nas moendas, as quais são movidas, principalmente, por turbinas a vapor, proveniente da queima do bagaço nas caldeiras; ou por motores elétricos ou hidráulicos.

O caldo produzido durante a moagem é composto, segundo Braile e Cavalcanti (1979), por uma solução contendo sacarose, açúcares redutores ${ }^{12} \mathrm{e}$ não-açúcares ${ }^{13}$. Esse caldo passa por um tratamento, por aquecimento e decantação, subdividindo-se, no processo de produção, em açúcar e em álcool, quando a usina gera os dois produtos.

O lodo resultante da decantação é submetido à filtração a vácuo. O líquido da filtração retorna ao processo e o resíduo sólido, conhecido por torta de filtro, é destinado à fertilização nos campos de cultivo de cana-de-açúcar.

A continuação da descrição do processo industrial, ilustrado na figura 9 , é focada na produção do álcool a partir do caldo obtido no processo de extração e enviado diretamente para a fabricação do álcool, pelo fato de o estudo não contemplar a produção de açúcar. Contudo, cabe diferenciar os dois tipos de destilarias de etanol:

a) destilarias anexas: que produzem álcool também a partir do produto da fermentação do melaço, subproduto da produção de açúcar, o chamado mosto de melaço;

b) destilarias autônomas: nas quais o álcool é obtido a partir da fermentação direta do caldo de cana.

O caldo, enriquecido com alguns nutrientes, é inoculado, de acordo com Braile e Cavalcanti (1979), com leveduras (fungo) do gênero

\footnotetext{
12 Os açúcares redutores são compostos por frutose e glicose (HORII, 1998).

${ }^{13}$ Os não açúcares são compostos por substâncias orgânicas e não orgânicas. As orgânicas são os aminoácidos, proteínas, gordura e cera; os não orgânicos são compostos por sais minerais.(HORII, 1998)
} 
Saccharomyces. Tais microorganismos irão reverter a sacarose $\left(\mathrm{C}_{6} \mathrm{H}_{12} \mathrm{O}_{6}\right)$ e transformá-la em álcool etílico ou etanol $\left(\mathrm{C}_{2} \mathrm{H}_{5} \mathrm{OH}\right)$ e dióxido de carbono $\left(\mathrm{CO}_{2}\right)$. O produto da fermentação é um substrato açucarado, denominado vinho, que é centrifugado para a obtenção e a reutilização das leveduras, enquanto o líquido é enviado às colunas de destilação.

Como é visto na figura 9 , na primeira coluna, obtém-se álcool de $45^{\circ} \mathrm{GL}$ (fração em volume) à $50^{\circ} \mathrm{GL}$, denominado flegma, e o efluente, que, segundo o IAC (1994), é responsável por mais de $60 \%$ da carga poluidora de uma destilaria: a vinhaça. Na coluna seguinte, de retificação, a concentração elevase à, no máximo, $97^{\circ} \mathrm{GL}$, segundo Almeida [197-?], sendo encontrado pela Fic (2004) na fração em massa do álcool na mistura de 93,2\% (mínimo 92,6\% e máximo 93,8\%). Este produto é o álcool etílico hidratado combustível, o qual é o produto do estudo de ACV deste trabalho. 


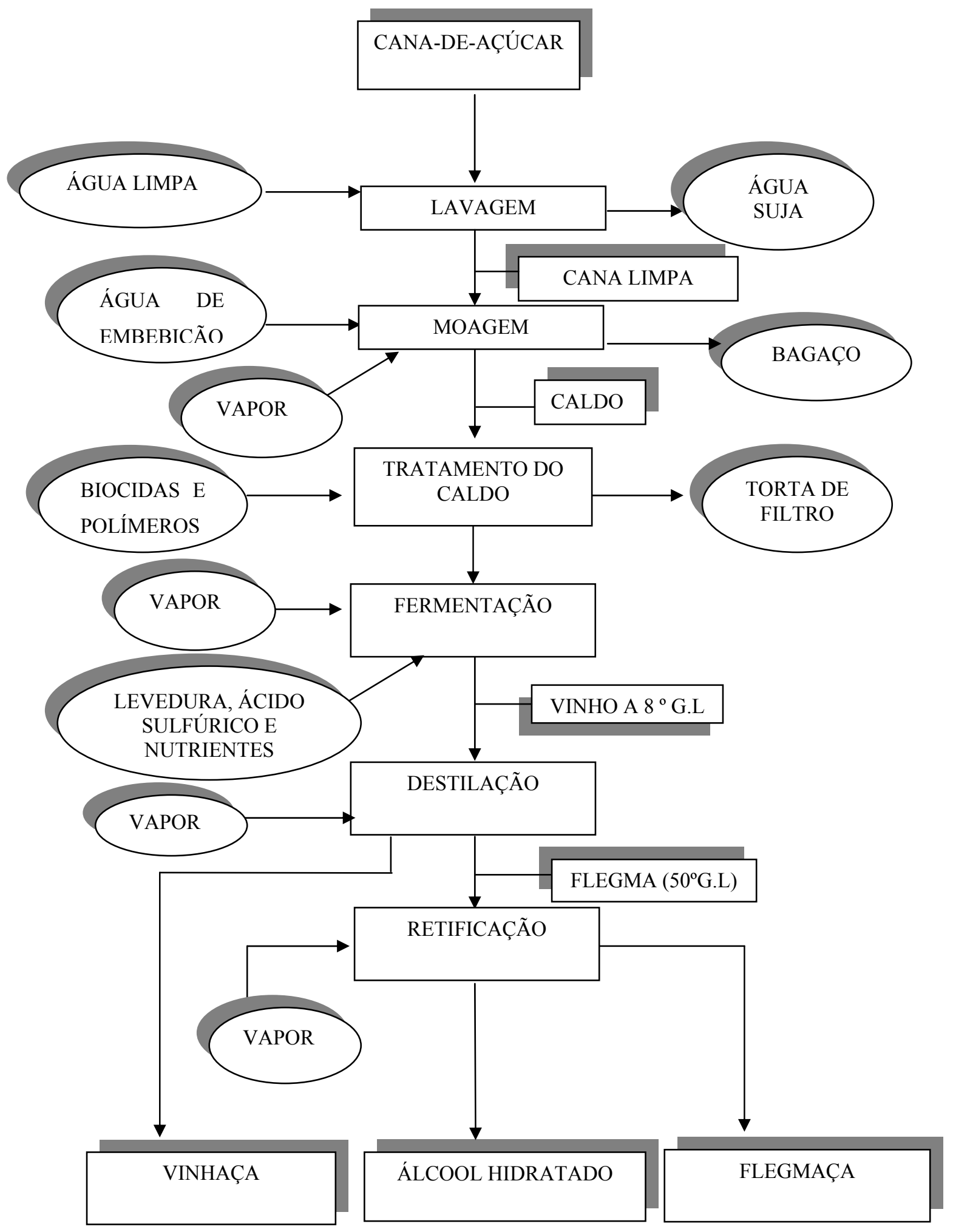

Figura 9 - Fluxograma do processo industrial do álcool etílico hidratado 
A geração de vapor é realizada a partir da queima do bagaço nas caldeiras, como mostra a figura 10, e a energia elétrica pela utilização de geradores a vapor, como mostrado na figura 11.

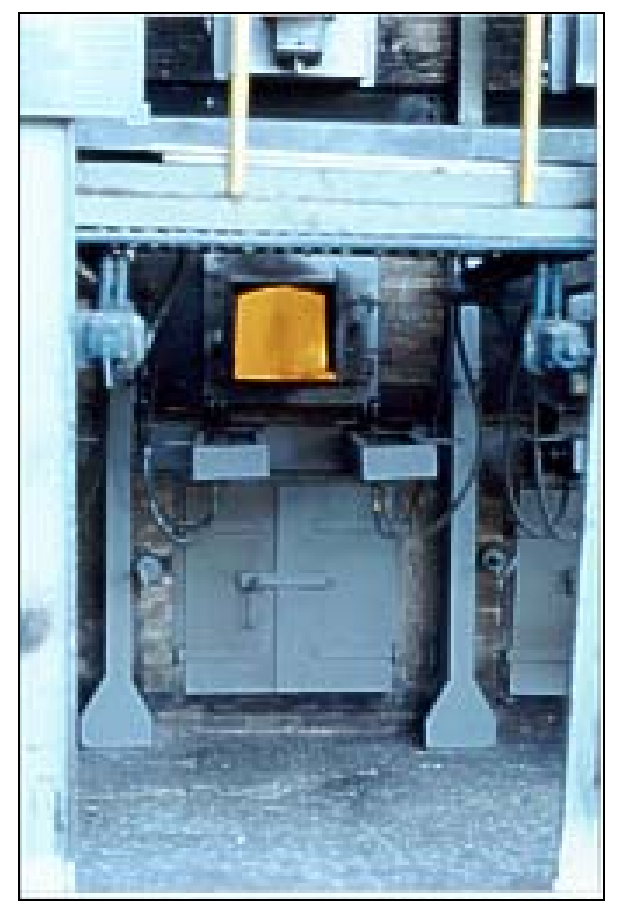

Figura 10 - Caldeira de combustão do bagaço

Fonte - OMETTO, A. (2000)

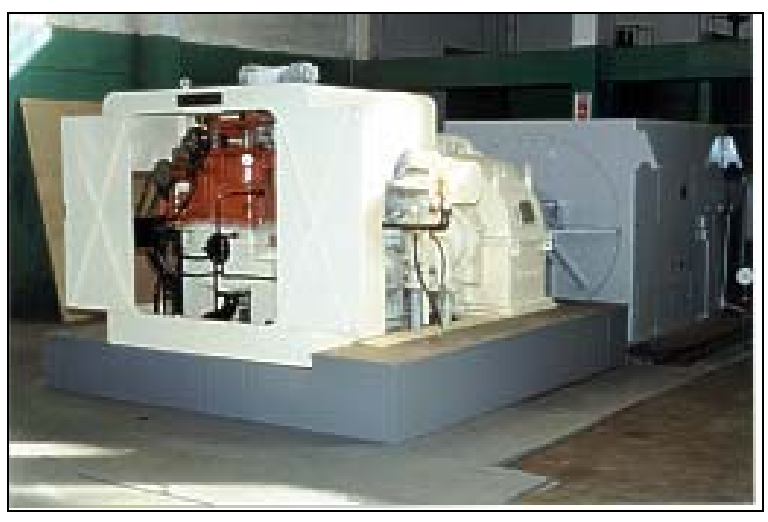

Figura 11 - Gerador de energia elétrica

Fonte - OMETTO, A. (2000)

A reutilização de subprodutos no ciclo de vida do álcool é caracterizada pela fertirrigação da vinhaça e torta de filtro nos campos de cultivo. A vinhaça ou vinhoto, como visto, é resultante da produção do álcool, após a fermentação 
do mosto e a destilação do vinho. Segundo Unido (1997) e Cetesb (1985), é o maior poluidor dentre os efluentes, variando seu desprendimento, dependendo da concentração (teor) alcoólica obtida na fermentação, de 10 a 18 litros de vinhaça por litro de álcool produzido, com altas temperaturas na saída dos destiladores, as quais variam de $85^{\circ} \mathrm{C}$ a $90^{\circ} \mathrm{C}$.

Quanto à composição, a vinhaça apresenta características específicas, bem estudadas por vários autores, e as quais variam conforme alguns fatores, segundo Cruz (1991), tais como: natureza e composição da matéria-prima, do mosto, do vinho, do tipo de aparelho destilatório e da condução da destilação. Contudo, a riqueza organo-mineral é alta em todos os tipos, tendo grande importância na aplicação em solos agrícolas.

Portanto, sua utilização nas lavouras de cana-de-açúcar, em substituição parcial ou total à adubação organo-mineral, tem sido largamente ampliada. Todavia Szmrecsányi (1994) afirma que o seu uso não pode ser excessivo nem indiscriminado, sob pena de comprometer o meio ambiente, com a salinização do solo e poluição dos aqüíferos, e a própria rentabilidade agrícola e industrial.

O transporte da vinhaça pode ser realizado por caminhões, canais abertos ou bombeados, realizando-se a aplicação, geralmente, por aspersão, como mostra a figura 12 .

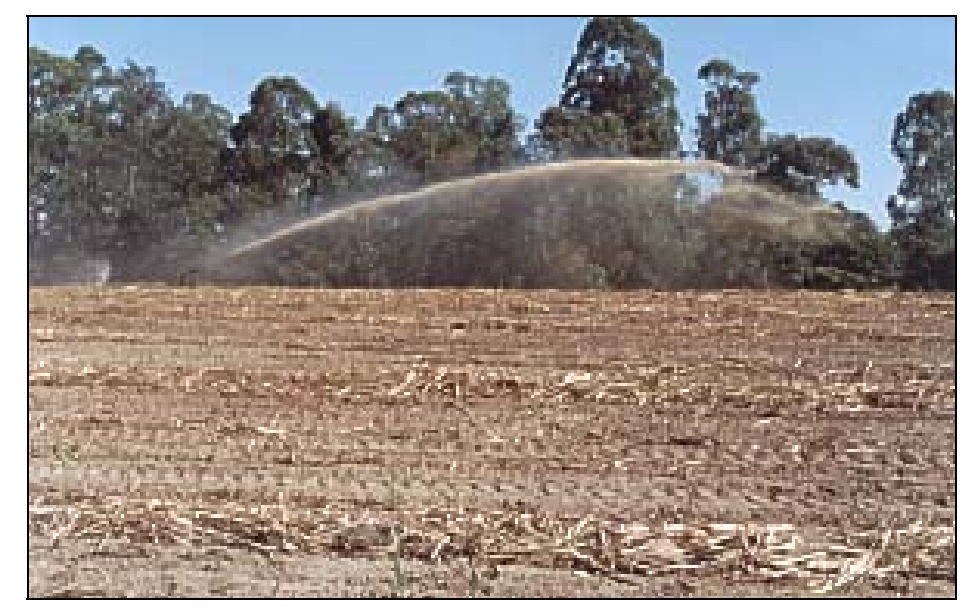

Figura 12 - Fertirrigação de vinhaça por aspersão

Fonte - OMETTO, A. (2000) 
A armazenagem do álcool é feita em tanques de concreto e a distribuição do etanol é realizada, por meio de caminhões a diesel, até os postos de gasolina. O uso do etanol hidratado ocorre pela sua combustão em veículos automotores.

O ciclo fecha-se com a absorção, pela cana-de-açúcar, durante seu crescimento, do $\mathrm{CO}_{2}$ emitido na combustão e demais fases do ciclo de vida do álcool.

A figura 13 representa todas as fases do ciclo de vida do álcool etílico hidratado, desde as etapas de produção da cana-de-açúcar, até o transporte interno, a produção industrial, a fertirrigação, a distribuição do produto e o consumo do etanol hidratado em veículos automotores. 

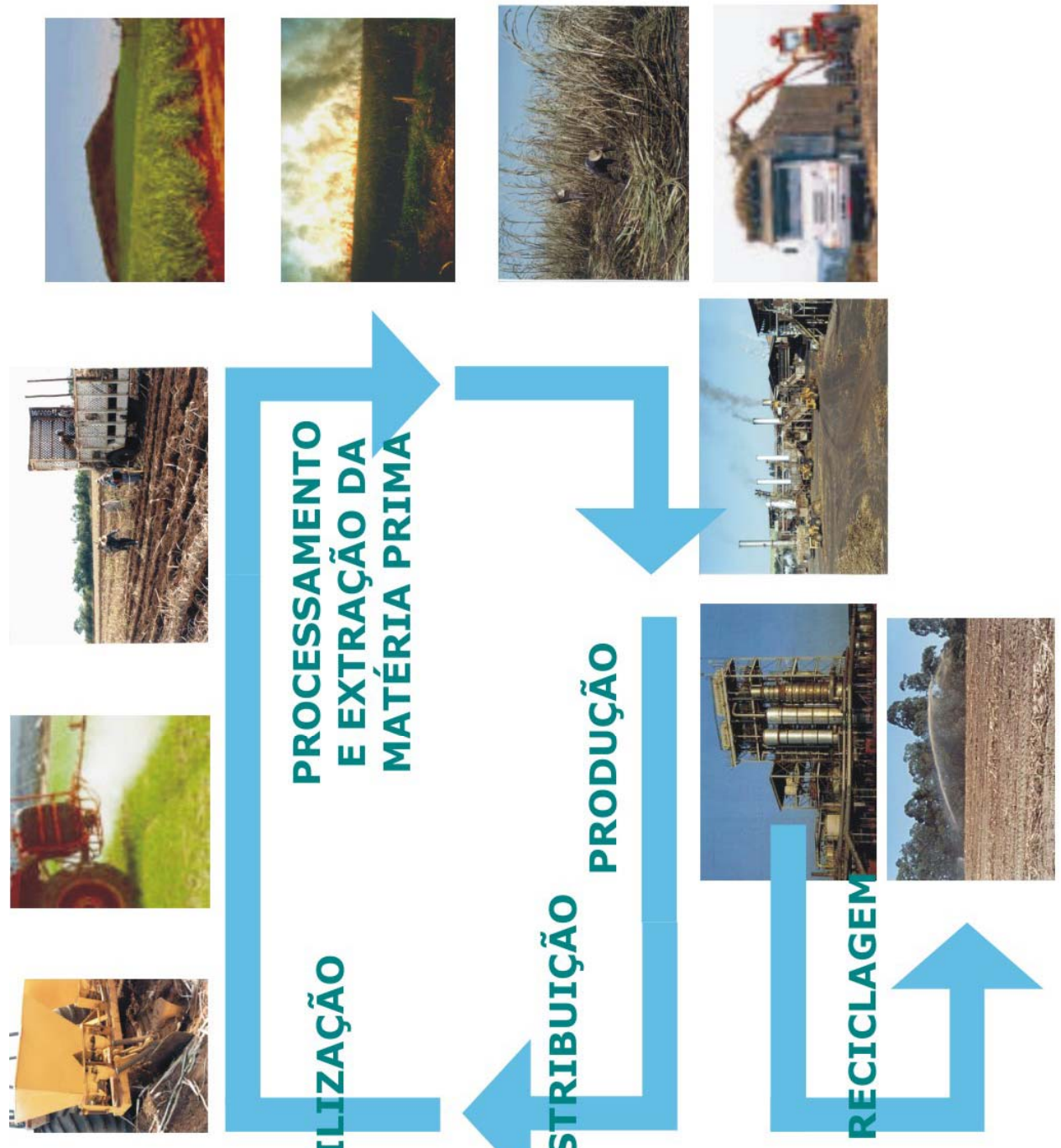

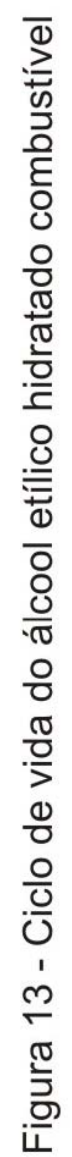
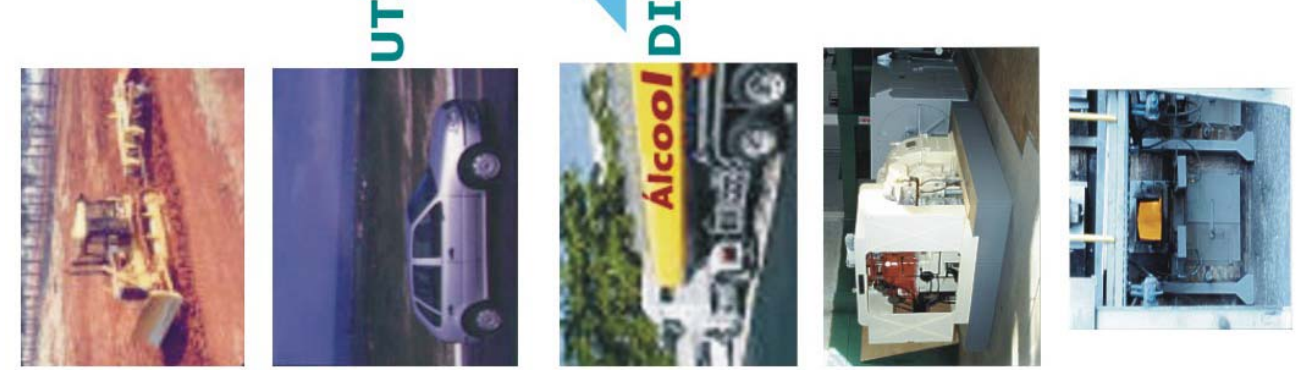


\subsection{Valoração ambiental pela Termodinâmica}

A valoração ambiental pode ser conceituada como a definição do valor relacionado ao recurso ambiental ou ao impacto ambiental. Dentre as várias formas de se valorarem tais recursos e impactos, encontram-se métodos que utilizam conceitos da ecologia, da engenharia, da física, da química, da biologia, da geologia, assim como da economia.

Contudo, de acordo com Merico (1996), tradicionalmente, a análise econômica, no contexto do capitalismo neoliberal, negligencia o pressuposto básico de que a biosfera é finita e de que a economia deve se ajustar aos limites do ambiente natural.

Merico (1996) comenta, ainda, que, com o crescente aumento da exploração dos recursos ambientais pela atividade produtiva, há uma crescente pressão, tanto por parte do poder público, quanto da sociedade organizada (ONGs) e das agências multilaterais (Banco Interamericano de Desenvolvimento - BID -, Banco Mundial e Fundo Monetário Internacional FMI) para que os custos ambientais e as valorações de degradações sejam incluídos nas análises de custo-benefício dos investimentos.

De acordo com Righetto (2001), o valor do recurso natural pode ser medido de acordo com seus atributos, ou seja, de acordo com o fluxo de bens e de serviços que o mesmo pode oferecer para a sociedade. Motta (1998) divide os atributos de acordo com os valores de uso e de não-uso dos fluxos.

O valor de uso (VU), segundo Merico (1996), Munashinghe (1992), Pearce e Turner (1990), Pearce (1995) e Motta (1998), pode ser dividido em valor de uso direto (VUD), valor de uso indireto(VUI) e valor de opção (VO), conforme as seguintes definições:

- VUD: utilização atual de um recurso na forma de extração de, insumos para a atividade de produção ou de consumo direto, de recreação e de visitação;

- VUI: benefício atual do recurso quanto às suas funções ecossistêmicas. Exemplo: manutenção da estabilidade climática, proteção dos mananciais, capacidade de assimilação dos resíduos industriais e humanos e proteção do solo; 
- VO: atribuição de valor em usos diretos e indiretos que poderão ser efetuados no futuro. Este valor existe na medida da incerteza da disposição do recurso no futuro, frente ao uso (direto ou indireto) que se pretende do mesmo. Basicamente, o valor de opção é a quantia que os consumidores estão dispostos a pagar por um recurso não utilizado na produção, simplesmente para evitar o risco de não o ter no futuro.

Além destes, de acordo com os mesmos autores, há o valor de não-uso que pode ser denominado, também, como o valor de existência (VE). Este valor não se relaciona com nenhum uso direto ou indireto do recurso, mas existe na medida que as pessoas possuam uma posição moral, cultural, ética em relação à existência de espécies que não a humana.

Para Merico (1996), uma grande variedade de técnicas pode ser utilizada para quantificar os conceitos dos valores citados, sendo os métodos gerais e tradicionais de valoração ambiental os diretos e os indiretos.

Merico (1996) explica que os métodos de valoração direta podem estar relacionados com preços de mercado ou produtividade e são baseados nas relações físicas que descrevem a relação de causa e efeito, providenciando medida objetiva da degradação. Estes métodos são possíveis de se aplicar quando o impacto ambiental causado influencia a produção ou a capacidade produtiva do processo econômico. Um exemplo é a quantificação das perdas de produção agrícola provocadas pela chuva ácida para se valorar a qualidade do ar.

Os métodos indiretos, segundo Merico (1996) são aplicados quando um impacto ambiental não pode ser valorado, mesmo que indiretamente, pelo comportamento do mercado. Dentre eles, segundo Antunes (2001), há métodos neoclássicos, como a disponibilidade de pagar, os quais tendem a valorar o meio ambiente desconsiderando os fatores ambientais. Em tese, determinado ecossistema poderia ser totalmente destruído porque as pessoas envolvidas não têm nenhuma, ou quase nenhuma, disposição de pagar por sua preservação.

Antunes (2001) exemplifica a distorção deste modo de valoração, aplicando-o a um servente de pedreiro que, possivelmente, consideraria $\mathrm{R} \$ 100$ 
mil muito por uma gleba de mata virgem, ao mesmo tempo em que um grande empresário, também envolvido na questão, poderia achar a mesma quantia irrisória por tal terra. Isso mostra que a capacidade de pagamento do usuário do bem natural é diferente e como tal, o valor do bem difere.

Esta crítica é reforçada por Quadros (1991), que comenta que as pessoas têm sua visão de mundo muito influenciada pela sua posição na sociedade e no mercado de trabalho. Antunes (2001) considera essa discussão muito pouco realizada e muito importante, pois tal "bem" ambiental ser "muito valioso" é indubitável, mas "muito valioso" é um conceito muito abstrato e subjetivo, o que pode levar a decisões inadequadas e, principalmente, irreversíveis.

May (1995), sem ambigüidades, critica a posição favorável aos custos efetivos pela valoração monetária, em especial a contingente por "(...) não ser cientificamente bem fundamentada" (p. 08).

Contudo Pearce et al. (1989) argumentam que, à medida que os preços de mercado dos produtos não refletem o verdadeiro valor dos recursos e serviços naturais utilizados para produzi-los, há uma divergência entre custo privado e custo social.

Righetto (2001) indica que a valoração ambiental também objetiva a mensuração do custo externo, ou seja, o valor do dano ambiental. Esta é a visão relacionada à Economia da poluição, a qual trata do valor do impacto dos aspectos ambientais relacionados às emissões, os quais, normalmente, não são cobrados do poluidor.

De acordo com Merico (1996), para reduzir o "abismo" entre custo privado e social, o economista Artur Pigou, já em 1920, propôs a criação de um mecanismo de internalização de custos ambientais, ou, de acordo com o jargão econômico: "a internalização das externalidades negativas". Este é o Princípio Poluidor Pagador, adotado desde 1975 pela Organization for Economic Cooperation and Development (OECD), o qual norteia, também, a legislação ambiental brasileira, expressa em Brasil (1981).

Antunes (2001) explica a necessidade deste mecanismo pela inexistência de mercados organizados que considerem os valores do meio 
ambiente. Além disso, o problema ambiental aparece porque o custo da degradação ou da exploração não é corretamente apreendido pelos agentes. Assim, como a natureza é um bem público, a ação de um agente sobre ela gera externalidades aos outros, necessitando que essa falha de mercado seja sanada.

Uma alternativa apontada por Coase (1960) é a privatização da natureza pois, estando os direitos de propriedade claramente definidos, a interação via mercado levará a uma solução ótima apropriada.

O que esta visão ignora, de acordo com Amazonas (1994), é que a privatização dos direitos sobre a natureza não soluciona o problema, pois a natureza é um bem indubitavelmente público. Antunes (2001) critica a privatização do meio por ser uma distorção dos direitos difusos, por meio da qual somente alguns agentes econômicos poderão decidir o destino de algo que pertence a todos.

Em oposição à privatização, Antunes (2001) considera que certas questões ambientais devem ser abdicadas da valoração monetária. De acordo com Quadros e Canuto (1997),

(...) nem todos os valores de recursos são traduzíveis em termos monetários de modo amplamente aceitável. Não apenas por contestação ou questionamento dos métodos adotados, como pelo fato de que a eficiência econômica não constitui o único critério considerado importante diretamente pela sociedade ou por decisores de políticas, colocando-se com frequência em conflito com outros objetivos possíveis. (QUADROS e CANUTO, 1997, p. V-W).

Dixon e Sherman (1990) defendem que:

(...) since the financial analysis is designed only to examine costs and benefits as measured by market prices, it leaves out key factors that are not bought or sold. Many of the benefits of conserving natural areas are difficult to measure and are not exchanged in markets. (DIXON e SHERMAN, 1990, p. 3).

Portanto, alguns aspectos ambientais não são passíveis de serem valorados monetariamente. Outros, seguindo os preceitos de medida de valor 
da economia política tradicional, são valorados pelo trabalho. Este, segundo Marx (1867), é definido como o esforço humano realizado para a produção de mercadorias.

No entanto, ao avaliarmos as questões ambientais, o conceito de trabalho transcende as questões puramente humanas, contendo, também, outros significados, advindos de outras ciências. Ao investigar o meio ambiente como um sistema, parte dos seus atributos pode ser medido por meio do significado de trabalho pela Termodinâmica Clássica, que é a capacidade de realizar trabalho mecânico, dado pela exergia; outros pelo significado de trabalho pela Termodinâmica aplicada à Ecologia, que é o trabalho ecossistêmico, dado pela emergia.

Pelo fato de a questão ambiental ser muitidisciplinar e, principalmente, transdisciplinar, a valoração ambiental econômica deve considerar as diversas definições de trabalho e indicar qual é a mais adequada para ser aplicada, seus motivos e delimitar o significado do valor calculado.

Tais clareza e transparência da valoração ambiental são importantes para não haver equívocos no valor de um bem natural, o qual, como já visto, incorpora valores que não podem ser monetarizados.

Os valores indicados nesta tese são limitados pelos conceitos abordados por dois métodos da Termodinâmica, não sendo, de modo algum, exaustivos.

Assim, busca-se indicar o valor do recurso ou do dano em termos energéticos, com possibilidades de aplicações diretas, principalmente em processos produtivos.

Esta aplicação é ratificada por Georgescu-Roegen (1971), que considera que a busca do desenvolvimento sustentável torna urgente a inclusão da entropia, dada pela Termodinâmica, na análise econômica, uma vez que o meio não tem capacidade ilimitada de absorver a alta entropia resultante dos processos econômicos.

Portanto, a Termodinâmica é a base metodológica da valoração aqui proposta dentro do arcabouço teórico da valoração ambiental. Pela sua limitação frente às questões ambientais, salienta-se a necessidade de outras 
avaliações complementares, multidisciplinares e transdisciplinares, a fim de avaliar o recurso ou o impacto ambiental como um todo.

Dentre os outros aspectos necessários para uma avaliação mais completa, incluem-se os sociais, os culturais, os bióticos (como a biodiversidade), os abióticos, de saúde, de segurança e de bem-estar. Além desses, há os impactos indiretos, a manutenção da capacidade de suporte do meio, assim como as próprias questões econômicas relativas à capacidade de pagamento do poluidor e, segundo Antunes (2001), o impacto sobre as finanças públicas.

Especificamente, as valorações ambientais propostas aqui se limitam a valorar, em termos energéticos, os insumos e as emissões decorrentes de processos produtivos, por meio das aplicações dos métodos da Emergia e da Exergia, respectivamente.

A utilização da Emergia e da Exergia no enfoque ambiental já foi realizada por outros autores como Odum (1996), Pereira e Nebra (1999), Szargut (1999), Giannatoni (2002), Ortega (2003), Rosen e Dincer (1997), Brown e Harendee (1996), Campbell (2001), Comar (1999), Connelly e Koshland (1997), Cornelissen (1997), entre vários. Contudo, devido às suas limitações, aplicações, conceitos e interpretações, a valoração ambiental indicada pela emergia se refere, especificamente, ao consumo de energia solar equivalente à do trabalho ecossistêmico para a formação dos insumos e dos serviços; e pela exergia, ao impacto físico-químico direto das emissões atmosféricas gerado pelo trabalho mecânico disponível destas.

Os resultados de tais valorações podem melhorar o entendimento da dinâmica ambiente-homem-produção, quantificar as perdas, tendo em vista o processo e o ambiente, assim como indicar melhorias - de modo quantitativo da eficiência produtiva e ambiental, conhecida como eco-eficiência. Além disso, permitem comparar e melhorar as eficiências da formação ecossistêmicas de produtos e, principalmente, integrar as ciências exatas e humanas para mensurar os aspectos ambientais.

A aplicação das questões ambientais na Termodinâmica evoluiu de acordo com o aspecto da qualidade da energia, a qual é baseada no trabalho. 
A definição e a quantificação dessa qualidade está em pleno desenvolvimento, contribuindo, com a própria evolução da Termodimâmica e da valoração ambiental.

\subsubsection{Evolução dos aspectos ambientais na Termodinâmica}

Para entender a inserção da questão ambiental na Termodinâmica, é importante compreender a origem dos fundamentos básicos termodinâmicos.

Segundo Mattarolo (1996), as primeiras definições e conceitos da Termodinâmica foram realizados no século XIX, quando duas "escolas do pensamento" coexistiram e se desenvolveram em caminhos paralelos e próximos. Uma delas era os "Pioneiros da Técnica", aqueles que sempre propunham soluções da engenharia para novas máquinas e a outra era os "Cientistas do Calor", que estudavam a capacidade do calor em ser transformado em trabalho mecânico. As duas correntes juntaram-se no final do século XIX, formando o que, atualmente, se denomina tecnologia.

Segundo Giannantoni (2002), o "nascimento" oficial da Termodinâmica é datado, convencionalmente, em 1824, ano da publicação do trabalho mais famoso de Sadi Carnot "Réflexion sur la puissance motrice du feu", onde o autor declara claramente as condições físicas (posteriormente formalizadas rigorosamente como o Segundo Princípio da Termodinâmica) relacionadas a uma específica qualidade da energia termal: sua capacidade (ou limite) de ser transformada em trabalho mecânico. De fato, ele enunciou que o calor não pode ser totalmente convertido em trabalho mecânico em um processo cíclico que absorva calor de apenas uma fonte quente. A capacidade do calor em ser transformado em trabalho depende da diferença de temperaturas, de acordo com a eq. (1):

$$
Q_{1}^{\prime}=Q_{1} \cdot\left(1-T_{2} / T_{1}\right)
$$

onde $Q_{1}$ 'é a fração de calor transformada em trabalho, $Q_{1}$ é o calor inicial à temperatura $T_{1}$, sendo $T_{1}$ a temperatura da fonte quente e $T_{2}$ da fria. 
Assim, pode-se perceber que a primeira forma de qualidade da energia apareceu no início da Termodinâmica, mostrando que há capacidades distintas de se transformar determinada energia em trabalho.

Contudo, segundo Giannantoni (2002), a comunidade cientifica internacional mostrou-se indiferente a tal descoberta fundamental, que diferencia a qualidade da energia entre o calor e o trabalho mecânico. Isso ocorreu porque a perspectiva da pesquisa dominante era a quantitativa, sendo, então, a qualidade da energia algo insignificante.

A efetiva verificação empírica do equivalente quantitativo entre calor e trabalho foi realizado apenas vinte anos depois, independentemente, por Joule e Mayer (1842 - 1848). Tal equivalência foi a base para a formulação do Primeiro Princípio da Termodinâmica e o passo fundamental para sua generalização sucessiva para o Princípio da Conservação da Energia.

Nesse período, conforme Giannantoni (2002) comenta, o conceito de qualidade na Termodinâmica se resumia à transformação de uma forma de energia em trabalho mecânico. O fato pode ser representado pelo significado de um generalizado coeficiente de Carnot $\left(\theta_{\mathrm{i}}\right)$, específico para cada forma de energia considerada $\left(E n_{i}\right)$, e definido na eq. (2) como:

$$
\theta_{\mathrm{i}}=E x_{\mathrm{i}} / E n_{\mathrm{i}}
$$

$\mathrm{Na}$ eq. (2), o termo $E x_{i}$, denominado Exergia (ou energia mecânica disponível), é assumido como o critério básico de referência, enquanto o coeficiente de Carnot $\left(\theta_{\mathrm{i}}\right)$ expressa a fração da energia inicial que pode ser transformada em energia mecânica equivalente. Assim, $\theta_{\mathrm{i}}$ sempre será menor a 1 em processos reais ou igual a um em processos reversíveis e conservativos.

Contudo, no final do século $X I X$ e início do século $X X$, estudos de Boltzmanns (1905) ${ }^{14}$ apud Giannantoni (2002), relacionados a sistemas vivos, retomaram a parte qualitativa da Termodinâmica. A partir desses estudos, Lotka (1922a, 1922b, 1925) sugeriu o Princípio da Máxima Potência como o Quarto Princípio da Termodinâmica. Alguns autores trabalharam com tal idéia,

\footnotetext{
${ }^{14}$ BOLTZMANN, L. (1905). Der zweite Haupsatz der mechanishen warme Theorie. Almanach der K. Acad. Wiss Mechanishe, Wien 36:255-299 (publicado como uma aula ministrada por Boltzman em 1886)
} 
mas não conseguiram sucesso com o "pensamento dominante" da época, exercido com a Primeira Lei da Termodinâmica.

Giannantoni (2002) relata que, no início de 1950, uma nova abordagem para sistemas vivos foi proposta por I. Prigogine, com a introdução do conceito de estruturas dissipativas, aquelas estruturas que não estão no equilíbrio termodinâmico. Desse modo, Prigogine retomou o aspecto qualitativo do Segundo Princípio da Termodinâmica, apontando a importância de sua aplicação.

Outra mudança na Termodinâmica ocorreu, a partir de 1955, em duas direções diferentes, mas complementares. Uma delas foi introduzida por $Z$. Rant, que enalteceu a importância do Segundo Princípio em aplicações práticas, por meio da Exergia. Do outro lado, H.T. Odum reconsiderou o conceito de qualidade da energia de um ponto de vista mais amplo, mostrando que há características mais abrangentes que a mera transformação em trabalho mecânico.

Giannantoni (2002) explica que, com as pesquisas de Odum (sem negar a abordagem exergética), ficou cada vez mais evidente que duas formas diferentes de energia (embora caracterizadas pela mesma quantidade de Exergia) eram capazes de induzir diferentes efeitos, especialmente em sistemas vivos. Isso porque as mesmas quantidades de energias podem se transportar em formas intrínsecas distintas de qualidade, associadas aos seus processos particulares de gênese. Esse histórico de formação consiste em uma série de processos bem definidos, desde formas de energia menos organizadas até formas mais sofisticadas.

Segundo Odum (1996) e Giannantoni (2002), esse novo padrão de qualidade foi denominado transformidade, porque caracteriza qualquer forma de energia como o resultado de outra forma que foi radicalmente transformada.

O conceito fundamental da transformidade foi o que possibilitou a introdução do novo conceito denominado Emergia. A escolha do nome, segundo Giannantoni (2002), advém da contração de duas palavras em inglês embodied e energy - que incorporam o significado do conceito. Pesquisas sucessivas sugeriram a referência do termo com o sentido da essência de algo 
que emerge. Este novo sentido representa ainda melhor o conceito de qualidade emergente associada a qualquer forma de energia durante seu processo de formação.

Desse modo, Odum (1983) progressivamente estendeu a validade do Princípio de Lotka para classes maiores de sistemas de organização própria, mostrando que os Princípios da maximização e da otimização são casos específicos do Princípio da Máxima Potência Emergética, introduzido com a Emergia. Tal princípio é explicado em Odum (1983):

In time, through the process of trial and error, complex patterns of structure and process have evolved...the successful ones surviving because they use materials and energies well in their own maintenance, and compete well with other patterns that chance interposes (ODUM, 1983).

Segundo Giannantoni (2002), para o Segundo Princípio da Termodinâmica, assim como para a exergia, o conceito de qualidade resumese na quantidade de trabalho mecânico disponível, sendo este representado pelo maior nível de qualidade.

Em contrapartida, pela nova perspectiva do Princípio da Máxima Potência Emergética, o trabalho mecânico é o de menor qualidade, aumentando esta conforme a forma de organização e de formação dos sistemas. Odum (1996) sugere que os sistemas conseguem ter a máxima eficiência com a sua própria organização, de modo a otimizarem seus processos produtivos pela retroalimentação dos fluxos ou pela configuração de seus elementos. Em suas palavras, Odum (1996) explica que "in competition among self-organizing process, network designs that maximize empower will prevail".

Para Giannantoni (2002), com a análise emergética é possível descobrir alguns processos estruturais em sistemas de organização própria, mais complexos que os efeitos dissipativos calculados pela Segunda Lei da Termodinâmica. A análise estrutural dos sistemas para a avaliação da qualidade da energia representa uma das mais importantes inovações trazidas com o conceito da Emergia. 
À luz da definição de Emergia $\left(E m_{i}\right)$, Transformidade $\left(T r_{i}\right)$ e Exergia $\left(E x_{i}\right)$, Giannantoni (2002) formula as eqs. (3) e (4) que relacionam a exergia com a emergia:

$$
\begin{aligned}
& \mathrm{Em}_{\mathrm{i}}=\mathrm{Tr}_{\mathrm{i}} . E x_{\mathrm{i}} \\
& \mathrm{Tr}_{\mathrm{i}}=E m_{\mathrm{i}} / E x_{\mathrm{i}}
\end{aligned}
$$

Giannantoni (2002) explica que a Transformidade, assim como a Emergia não representa uma ampliação dos efeitos mecânicos para a quantificação da qualidade da energia, mas considera outros efeitos que não são de natureza estritamente mecânica.

Desse modo, para Giannantoni (2002), estes efeitos, denominados de "meta-mecânicos", são considerados de qualidade superior ao mecânico e construídos a partir de uma quantidade de Exergia que atua como suporte físico para a organização de níveis superiores. Em outras palavras, Giannantoni (2004) parafraseou: comparando com a comunicação, é como se a Exergia fossem as letras para servir de alicerce ou base para a formação das palavras e a Emergia, o significado dessas palavras. Portanto, o significado da qualidade da energia, estruturada a partir de uma quantidade de Exergia, é dada pela Emergia.

Didaticamente, Giannantoni (2002) síntetiza as equações 2, 3 e 4, assim como o desenvolvimento da Termodinâmica frente às questões da qualidade da energia, pela eq. (5):

$$
E m_{i}=\operatorname{Tr}^{*}{ }^{*} n_{i}{ }^{*} \theta_{i}
$$

Na eq. (5), $\theta_{\mathrm{i}}$ representa a irreversibilidade, que consiste nas perdas das interações energéticas calculadas com a entropia.

A eq. (5) indica que, mesmo que um processo satisfaça o Princípio da Conservação de Energia, a sempre presente irreversibilidade, $\theta_{\mathrm{i}}$, leva a uma redução da quantidade de energia que realmente possa ser transformada em um equivalente de trabalho mecânico, isto é, em Exergia.

De outro modo, Giannantoni (2002) indica que a presença da $\operatorname{Tr}_{\mathrm{i}}$ expressa a capacidade de uma quantidade de Exergia induzir efeitos de qualidade superior ao trabalho mecânico, tanto no próprio sistema - por meio 
das cadeias de retroalimentação - como para sistemas vizinhos - por meio das diversas saídas interconectadas.

Ao mesmo tempo, a eq. (5) resume diversos pontos de vista e as diversas abordagens para a análise de sistemas termodinâmicos porque mostra que:

se a transformidade for negada, a análise será com relação à exergia;

se a transformidade e a irreversibilidade forem negadas, realizarse-á a avaliação tradicional de energia pela primeira lei;

se a irreversibilidade for negada, realizar-se-á a análise emergética de sistemas conservativos.

Giannantoni (2002) considera que a Emergia transforma as contribuições exergéticas em uma qualidade completamente nova e diferente. Enquanto a Exergia representa a quantidade útil de energia, em termos de energia mecânica, a quantidade física de Emergia considera a habilidade de essa forma de energia útil ser usada como um "veículo" de outras formas de trabalho. Dentre as diversas formas de trabalho, além do trabalho mecânico, há o conteúdo de informação disponível, a inovação tecnológica, a habilidade de aumentar os efeitos de retroalimentação do sistema, entre outros.

Com a abordagem moderna e sistêmica da Emergia, os tradicionais e bem conhecidos princípios da Termodinâmica podem ser vistos em uma perspectiva mais geral e seus contextos quantitativos podem ser valiosos à luz de um novo e profundo conceito de qualidade, incorporando o trabalho ambiental, tecnológico, cultural e humano. 


\subsubsection{Valoração ambiental pela Exergia}

Pela primeira lei da Termodinâmica, nada se cria e nada se perde, tudo se transforma. Portanto, se as transformações energéticas fossem regidas somente pela primeira lei, não haveria problemas em usar e reusar a mesma energia inúmeras vezes.

Contudo, todo processo apresenta perdas e a quantidade de energia que é possível ser transformada em trabalho mecânico e que esteja em desequilibro físico-químico com o ambiente pode ser quantificada pela segunda lei da Termodinâmica. Parte da energia dissipada que se acumula no ambiente pode ameaçar os ecossistemas em forma de poluição ou degradação ambiental.

Entre as duas leis da Termodinâmica, a segunda é a que mais se aproxima da quantificação dos fluxos naturais, em termos ecológicos, pois trata da qualidade da energia em termos de trabalho útil, propriedade nobre e dependente das características físico-químicas de equilíbrio com o meio.

Segundo Rosen e Dincer (1999), a produção, a transformação, o transporte e o uso final da energia e de produtos, na maioria das vezes, causam impactos significativos no ambiente. Um dos maiores custos ambientais associados são as emissões (térmica, química, nuclear, etc.) dos processos produtivos.

De acordo com Kotas (1995), Bejan et al. (1996) e Yantovskii (1994), a análise exergética, baseada na Segunda Lei da Termodinâmica, permite avaliar a magnitude da potência mecânica máxima disponível e perdida durante processos físico-químicos.

Para Rosen e Dincer (1999), a análise exergética é útil em muitas aplicações industriais, no entanto, devido a sua origem dentro da comunidade Termodinâmica, poucos pesquisadores investigaram o potencial da Exergia para aspectos estratégicos, como os ambientais.

Segundo Connelly e Koshland (1997), é necessário o desenvolvimento de uma técnica para valorar a Exergia em processos industriais, explorando o 
seu significado em termos ambientais e de eficiência para poderem ser utilizados para a otimização e a melhoria ambiental.

Rosen e Dincer (1997) indicam que, no intuito de reduzir o consumo de energia e o impacto ambiental, há a necessidade de se compreenderem as relações interativas entre a Exergia e o ambiente.

Cornelissen (1997), em sua investigação das relações entre a Termodinâmica e o desenvolvimento sustentável, observou que uma das ferramentas-chave para a obtenção do desenvolvimento sustentável é a análise exergética.

A análise exergética é um método que utiliza os princípios de conservação da massa e da energia, em conjunto com a Segunda Lei da Termodinâmica e que pode ser aplicado para o projeto e a análise de sistemas energéticos, de processos produtivos ou de ciclos de vida de produtos.

Tal método localiza e quantifica as fontes de irreversibilidade internas e as perdas externas, podendo revelar quais mudanças podem ser executadas para a otimização do processo produtivo e do conseqüente ganho ambiental.

De acordo com Sciubba (1999) e Pinto et al. (2000), a Exergia pode ser considerada, também, para avaliações de impacto ambiental. Para Wark (1996), Exergia é a medida do máximo trabalho mecânico disponível, em trocas somente com o ambiente e em processos reversíveis, para um sistema equilibrar-se com o ambiente em termos físicos - temperatura e pressão - e químicos.

Assim, segundo Rosen e Dincer (1997) e Ayres et al. (1998), um caminho para relacionar a Termodinâmica e o impacto ambiental é a Exergia, porque ela é uma medida da diferença do estado de um sistema em relação ao ambiente. A diferença é nula somente quando o sistema está em equilíbrio com o ambiente.

Segundo Moran (1989), Brodyanski et al. (1994) e Bejan et al. (1996), as Exergias associadas aos fluxos de emissões residuais podem ser avaliadas como o potencial de causar danos ambientais, particularmente quando liberadas em larga escala no ambiente. Assim, para Rosen e Dincer (1999), é 
importante avaliar o conteúdo exergético de uma emissão residual, a fim de se avaliarem maneiras para a redução do impacto ambiental.

Rosen e Dincer (1999) consideram que a Exergia de uma emissão que se atribua ao seu desequilíbrio físico (temperatura e pressão) não apresenta significativo potencial de impacto ambiental, pois as diferenças de pressão entre uma emissão e o ambiente normalmente se dissipam logo após a emissão e as diferenças de temperatura são localizadas, normalmente, perto da fonte de emissão e podem ser controladas. Entretanto a Exergia de uma emissão causada pelo desequilíbrio químico (Exergia química) é, freqüentemente, significativa e difusa, e, conseqüentemente, de difícil controle e de alto potencial de impacto ambiental.

Portanto a análise exergética pode ser uma maneira de se valorar a perda de trabalho útil que ocorre nas emissões e, de outro lado, de quantificar o ganho obtido quando os resíduos são utilizados em outros processos, ou reciclados.

Contudo essa valoração limita-se à quantificação do trabalho útil necessário que o meio absorve para a substância (aqui tratada como resíduo ou efluente) se equilibrar com o meio, em termos físicos (temperatura e pressão) e químicos (pelas espécies que compõem o meio e seus respectivos potenciais químicos).

Assim, pelo conceito de Exergia, a sua aplicação pode ser indicada, segundo Ometto e Roma (2004), para a valoração dos impactos ambientais diretos físico-químicos que as emissões podem causar, quando em desequilíbrio físico-químico com o ambiente.

Dessa forma, apesar de a avaliação exergética não cobrir todos os itens necessários para uma análise ambiental completa, de acordo com a Resolução Conama 01 (Brasil, 1986), ela se mostra muito útil e importante para se quantificar, de forma cientificamente correta, parte do impacto ambiental ocasionado por um efluente.

Além disso, planos e programas regionais podem se basear na análise exergética para formar políticas públicas e servir de base para zoneamentos ambientais, avaliações ambientais e estudos de impactos ambientais. 


\subsubsection{Valoração ambiental pela Emergia}

A Emergia é definida, segundo Odum (1996), como o total de energia solar equivalente usada, direta ou indiretamente, para produzir uma específica forma de energia ou produto. Pode ainda ser definida, segundo Scienceman (1989), como toda energia solar incorporada para a obtenção de um produto, incluindo os processos da natureza e os humanos.

Desse modo, a Emergia quantifica toda a cadeia de produção de um determinado produto, desde a formação das matérias-primas naturais até as da manufaturadas. Por isso, essa metodologia apresenta grande aplicação para valorar os insumos consumidos durante o ciclo de vida de produtos, necessitando, para isso, incluir as fases de distribuição, de consumo e de pósconsumo do produto.

A teoria da energia incorporada, ou Emergia, sugere que os recursos naturais e antrópicos se organizem de modo a maximizar a produção de bens naturais e antrópicos, com menores danos ao meio ambiente e à sociedade.

Segundo Comar (1995), a avaliação emergética permite a comparação e a incorporação dos custos e dos benefícios ambientais com os econômicos, a fim de fornecer uma perspectiva mais ampla como subsídio na tomada de decisões administrativas.

A aplicação de conceitos ecológicos para a análise da sociedade humana, por meio da Emergia, foi introduzida por Odum (1971), e seus conceitos podem ser utilizados na manufatura, a fim de indicar meios para que o sistema possa ser organizado de acordo com o princípio da maximização de sua energia incorporada, ou seja, do aumento da eficiência, em termos emergéticos, na formação do produto.

Atualmente, o cálculo sócio-ambiental constitui uma extensão da contabilidade econômica tradicional. Compreender as funcionalidades entre energias empregadas e ciclos produtivos dos materiais pode possibilitar um melhor entendimento do complexo relacionamento entre a biosfera e a sociedade. 
Para Odum (1996), como a Emergia é o somatório da energia solar incorporada dos recursos naturais e econômicos utilizados em um processo natural ou antrópico, ela incorpora os serviços ambientais e sociais realizados.

Desse modo, a avaliação emergética é, segundo Brown e Harendeen (1996), uma técnica de análise quantitativa que determina o valor de recursos monetários e não-monetários, de serviços e de commodities numa unidade comum: a energia solar equivalente.

Para Campbell (2001), é, ainda, um método analítico que pode quantificar as contribuições da humanidade e da natureza para a existência de sistemas ambientais e econômicos.

Assim, a Emergia pode ser uma ferramenta muito útil para comparar diferentes alternativas de produção, pois, segundo Odum (1996), coloca todas as variáveis ambientais, sociais e econômicas numa mesma base.

Como se verifica, a Emergia pode ser utilizada como ferramenta de valoração ambiental de um produto natural ou antrópico, por meio da contabilização da energia de formação dos insumos e dos serviços utilizados. Dessa forma, a aplicação da valoração ambiental pela Emergia em ACV mostra-se eficiente, podendo ser uma forma de valoração do consumo de recursos no ciclo de vida avaliado. 


\section{Capítulo 3. Metodologia}

O trabalho inicia-se a partir da revisão bibliográfica sobre a gestão ambiental de processos e produtos, a ACV, as atividades do ciclo de vida do álcool combustível hidratado e as aplicações de métodos termodinâmicos para a avaliação e a valoração ambiental.

Os resultados são estruturados como um estudo de ACV, cuja estrutura metodológica é normatizada internacionalmente pela ISO e, no Brasil, pela ABNT. Tal estrutura determina as fases e os procedimentos gerais da execução de um estudo de $\mathrm{ACV}$, de acordo com as normas mundiais da série ISO 14.040, e as correspondentes nacionais da série NBR ISO 14.040. As características-chave para a realização de um estudo de ACV, segundo ABNT (2001), são:

- abordagem sistemática e adequada com relação aos aspectos ambientais de sistemas de produto, desde a aquisição de matériaprima até a disposição final;

- possibilidade de variação do detalhe e do período de tempo de um estudo da ACV, dependendo da definição do objetivo e do escopo;

- transparência quanto ao escopo, suposições, descrição da qualidade dos dados, dos métodos e apresentação dos resultados;

a possibilidade de inclusão de novas descobertas científicas e melhoria no estado da arte da tecnologia;

- inexistência de base científica para reduzir resultados da ACV a um único número ou pontuação globais;

- inexistência de um único método para conduzir estudos da ACV, mas o método escolhido deve seguir a Norma NBR ISO 14.040. 
Assim, a estrutura metodológica do estudo da ACV do álcool combustível segue as normas ISO 14.040 e NBR ISO 14.040, mostradas na figura 14.

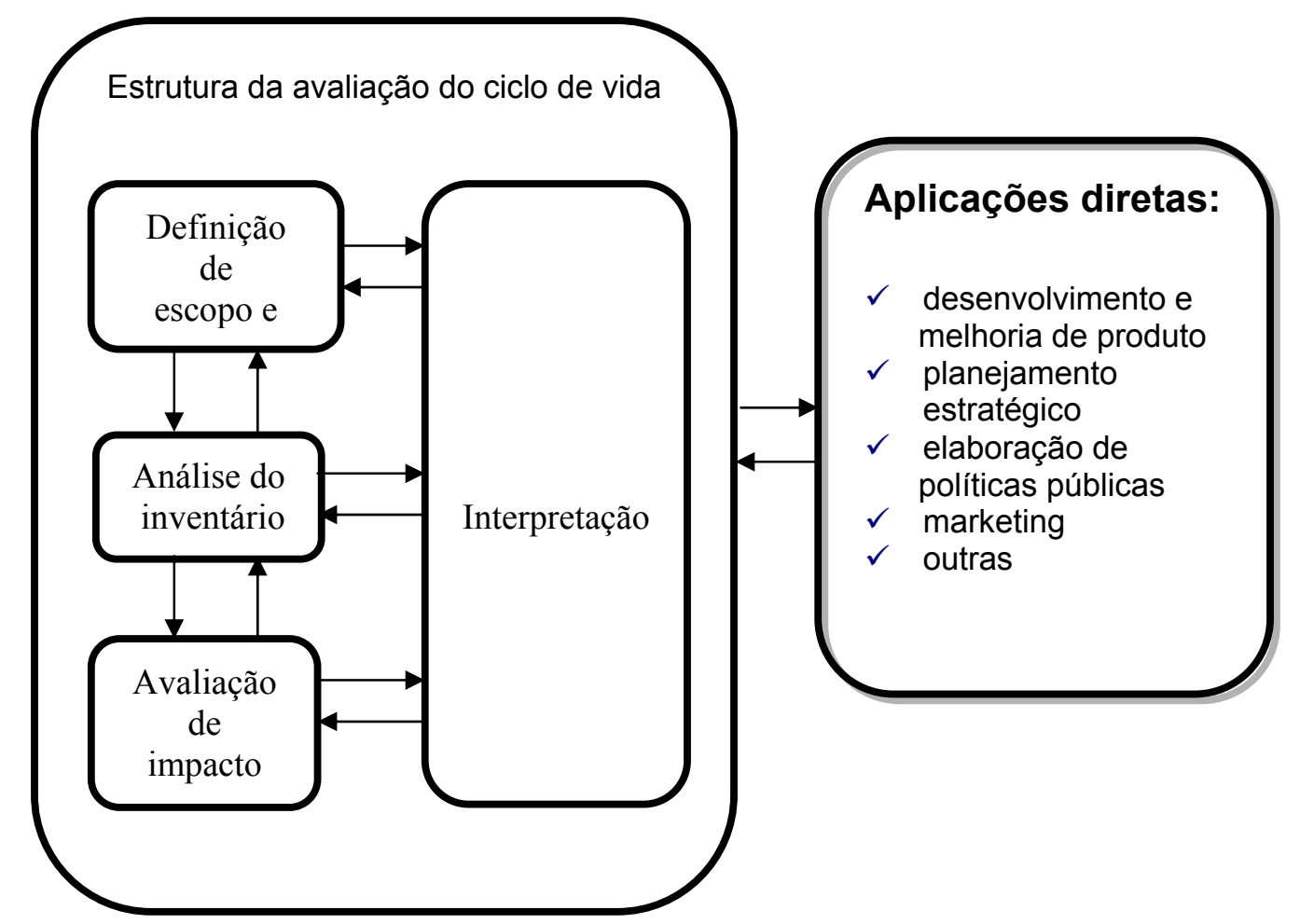

Figura 14 - Fases de uma ACV

Fonte - ISO (1997); ABNT (2001)

De acordo com a norma ISO 14.040 e NBR ISO 14.040, citada em Schaltegger (1996), Ciambrone (1997), Setac (1991), Udo de Haes et al. (2002), ISO (1997), ABNT (2001), ABNT (2004a), ABNT (2004b) e Wenzel et al. (1997), a estrutura metodológica para a realização da ACV é dividida em quatro fases:

1. Definição do objetivo e do escopo: o objetivo e o escopo da ACV devem ser coerentes com a aplicação pretendida e claramente definidos, incluindo as decisões que se devem apoiar na avaliação;

2. Análise do inventário do ciclo de vida (ICV): envolve a coleta de dados e os procedimentos de cálculo para quantificar as entradas e as saídas pertinentes do sistema de produto. Isso requer a identificação e a quantificação dos dados de uso de recursos e de liberações no ar, na água e no solo, associados com o sistema. Podem ser feitas interpretações de 
tais dados, dependendo dos objetivos e do escopo do ACV. Os dados constituem a base para a próxima etapa: a avaliação do impacto do ciclo de vida;

3. Avaliação do impacto do ciclo de vida (AICV): esta fase é dirigida à avaliação da significância de potenciais impactos ambientais, partindo dos resultados da análise do inventário. O nível de detalhe, a escolha dos impactos avaliados e os métodos dependem do objetivo e do escopo do estudo. Segundo ISO (2002) e ABNT (2004b), as etapas obrigatórias da avaliação de impacto do ciclo de vida são:

3.1. Seleção das categorias de impactos ${ }^{15}$;

3.2. Classificação dos aspectos nos impactos, de acordo com sua importância;

3.3. Caracterização pela valoração do aspecto, de acordo com sua magnitude em relação ao impacto.

4. Interpretação: segundo ABNT (2001) e ISO (2000b), nesta fase os resultados das etapas da análise de inventário e da avaliação de impacto são combinados com o objetivo e escopo, de forma consistente, visando a alcançar conclusões e recomendações. As limitações do estudo são, também, indicadas nesta fase, de forma transparente. A interpretação é apresentada neste trabalho no último capítulo, denominado conclusões.

Há, ainda, de acordo com a ABNT (2001), a elaboração do relatório e a análise crítica realizada por especialistas externos, quando necessária. Essas fases estão representadas, respectivamente, por esta Tese e pela sua defesa.

Assim, este estudo da ACV segue a estrutura metodológica proposta pela ISO e ABNT, dividindo-se as normas e os métodos para a realização de cada fase como mostra a tabela 1.

\footnotetext{
${ }^{15}$ Categoria de impacto é a classe que representa as questões ambientais relevantes às quais os resultados do ICV podem ser associados (ABNT, 2004b).
} 
Tabela 1: Estrutura metodológica e métodos utilizados

\begin{tabular}{c|c|c}
\hline FASE da ACV & Norma & Método \\
\hline $\begin{array}{c}\text { 1. Definição do objetivo e } \\
\text { escopo }\end{array}$ & $\begin{array}{c}\text { ISO 14040, ISO 14041, NBR ISO } \\
14040, \text { NBR ISO 14041 }\end{array}$ & EDIP \\
\hline $\begin{array}{c}\text { 2. Análise do inventário do } \\
\text { ciclo de vida }\end{array}$ & $\begin{array}{c}\text { ISO 14040, ISO 14041, NBR ISO } \\
14040, \text { NBR ISO 14041 }\end{array}$ & EDIP \\
\hline $\begin{array}{c}\text { 3. Avaliação do impacto do } \\
\text { ciclo de vida }\end{array}$ & $\begin{array}{c}\text { ISO 14040, ISO 14042, NBR ISO } \\
14040, \text { NBR ISO 14042 }\end{array}$ & EDIP \\
\hline Exergia \\
\hline Interpretação & ISO 14040, ISO 14043, NBR ISO & EDIP \\
\hline
\end{tabular}

Desse modo, o método para a realização da ACV do álcool etílico hidratado combustível é baseado no EDIP, de acordo com Wenzel et al. (1997), aplicando-se para a fase de avaliação de impacto, além do EDIP, os métodos da Exergia e da Emergia, a fim de, respectivamente, valorar o potencial de impacto das emissões atmosféricas e dos recursos consumidos do sistema.

O método EDIP foi utilizado neste estudo de ACV por ser científica e tecnicamente comprovado, além de internacionalmente aceito e utilizado. O EDIP foi desenvolvido por meio de um programa de cooperação de quatro anos entre o Instituto de Desenvolvimento de Produto (IPL), a Universidade Técnica da Dinamarca (DTU), a Confederação das Indústrias Dinamarquesas, a agência de proteção ambiental dinamarquesa, o Ministério do Meio Ambiente da Dinamarca e cinco indústrias dinamarquesas.

Atualmente, o EDIP é o método de referência do Ministério do Meio Ambiente da Dinamarca, conhecido pelos profissionais de ACV de todo o mundo, utilizado no mais recente software de ACV, público, transparente, desenvolvido em meio acadêmico, técnico e científico e com diversas aplicações em todo o mundo. 
O método da exergia é baseado na Termodinâmica Clássica e o da emergia engloba aspectos da Termodinâmica para avaliações ecossistêmicas. Ambos os métodos também são técnica e cientificamente comprovados.

\subsection{Definição do objetivo e escopo}

Na primeira fase de um estudo da ACV, de acordo com ABNT (2004a), o objetivo deve estabelecer a aplicação pretendida de modo claro e consistente, incluindo as razões para conduzir o estudo e o público-alvo.

Em princípio, segundo a ABNT (2004a), é importante considerar que um estudo de ACV é iterativo e que a definição do objetivo e do escopo pode sofrer alterações durante a realização do estudo, à medida que os dados e as informações são coletados. Além disso, podem surgir limitações imprevistas, restrições ou informações adicionais. Tais modificações, embora possíveis, devem ser devidamente documentadas e justificadas.

Segundo ABNT (2001), para a definição do escopo, os seguintes itens devem ser considerados e claramente descritos:

- as funções do sistema de produto ou, no caso de estudos comparativos, dos sistemas;

a a unidade funcional;

a o sistema de produto a ser estudado;

a as fronteiras do sistema de produto;

o o procedimento de alocação;

- os tipos de impacto, o método de avaliação de impacto e a interpretação subseqüente a ser usada;

o requisito dos dados;

a as considerações;

a as limitações;

- os requisitos da qualidade dos dados iniciais;

a o tipo de análise crítica e 
ـ o tipo e o formato do relatório requerido para o estudo.

Nos pontos levantados na definição do escopo, os principais elementos são determinados, em ISO (1998), Schaltegger (1996) e ABNT (2004a), como:

口 Função do sistema: finalidade para a qual o produto estudado se destina, ou seja, a característica de desempenho do produto;

\Unidade funcional: medida do desempenho das saídas funcionais do produto ou do serviço que será utilizada no estudo. A unidade funcional define a quantificação da função identificada, fornecendo uma referência com a qual os dados de entrada e de saída são relacionados e padronizados (num sentido matemático). Portanto, a unidade funcional deve ser claramente definida e mensurável a fim de assegurar a comparabilidade de resultados da $\mathrm{ACV}$;

¿ Fluxo de referência: quantidade do produto que é necessária para realizar a função expressa pela unidade funcional;

$\checkmark$ Fronteiras do sistema inicial: define quais processos elementares ${ }^{16}$ serão incluídos no sistema a ser modelado. O ideal seria que o sistema de produto fosse modelado de tal forma que as entradas e as saídas fossem fluxos elementares ${ }^{17}$; contudo, em muitos casos, dados, tempo ou recursos impedem essa abrangência. A definição do limite do sistema, estabelecido de modo iterativo, deve estar de acordo com os objetivos do estudo, com a aplicação pretendida, com as considerações realizadas, com a disponibilidade de dados e com o critério de corte (massa, energia e relevância ambiental);

๑ Unidade de processo: é a menor parte de um sistema de produto para a qual os dados são coletados visando à realização de uma ACV. Este é o volume de controle de cada atividade do ciclo, necessitando ser caracterizado, principalmente pelas entradas e pelas saídas. A figura 15 representa uma unidade de processo e os fluxos de entrada e de saída.

\footnotetext{
${ }^{16}$ Processos elementares são as subdivisões dos sistemas de produto e interligados por fluxos de produtos intermediários e/ou resíduos para tratamento, a outros sistemas de produto por fluxos de produto e ao meio ambiente por fluxos elementares.

${ }^{17}$ Fluxos elementares são matéria ou energia que entra ou deixa o sistema de produto sem, respectivamente, prévia ou posterior transformação humana (ABNT, 2001).
} 


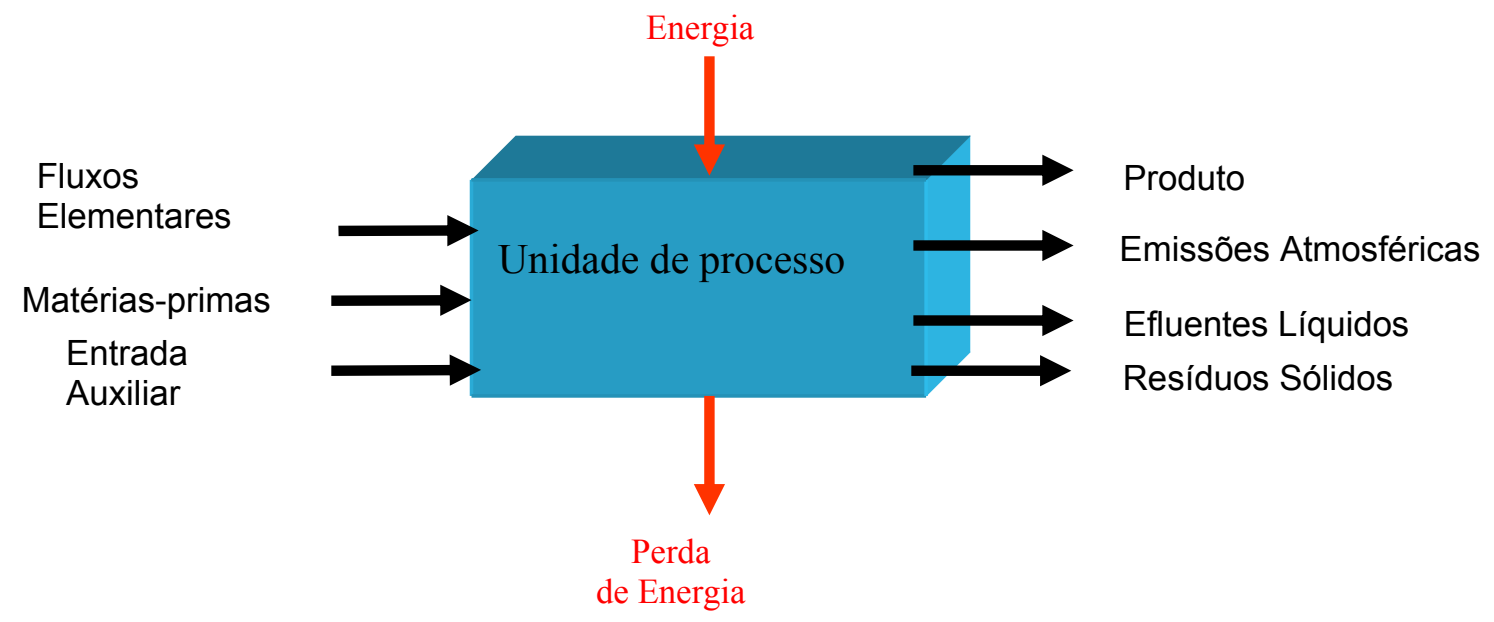

Figura 15 - Unidade de processo e fluxos relacionados

Segundo ISO (1998) e ABNT (2004a), as entradas auxiliares são os materiais que são utilizados na unidade de processo, mas não constituem parte do produto, como por exemplo, os catalisadores.

É importante a descrição da qualidade dos dados para compreender a confiabilidade dos resultados do estudo e interpretá-los. Um dos aspectos é a identificação da fonte dos dados, que podem ser primários - amostra direta do processo analisado; secundários - revisão bibliográfica ou entrevistas ou suposições realizadas por analistas com alto grau de experiência e conhecimento comprovado do processo.

Na definição do objetivo e do escopo, Wenzel et al. (1997) apontam alguns pontos, a fim de nortear o método do trabalho, tais como:

- definir a finalidade, os motivos e a aplicação do estudo;

- definir o público-alvo a ser atendido pelo estudo;

- na fase da definição do objetivo, as perguntas a que o estudo responda devem ser claramente elaboradas;

- definir a função ou a unidade funcional do sistema;

- definir os limites do sistema;

- os procedimentos de alocação dos dados;

- os tipos de impactos e os métodos de avaliação de impacto; 
- a fonte de dados e as informações;

- as considerações e as hipóteses;

- a forma de revisão crítica;

- o tipo e o formato do relatório do estudo;

- a "extensão" da análise - onde iniciar e parar o estudo do ciclo de vida;

- a "largura" da análise - quantos e quais subsistemas incluir;

- a "profundidade" da análise - o nível de detalhes do estudo.

A definição do objetivo e do escopo fornece o plano inicial para a realização da ACV e para a elaboração da segunda etapa do estudo da ACV: a Análise de Inventário.

\subsection{Análise de inventário}

De acordo com ISO (1998) e ABNT (2004a), a análise de Inventário do Ciclo de Vida (ICV) envolve a coleta de dados e os procedimentos de cálculo a fim de quantificar:

- as entradas de energia, de matéria-prima, auxiliares e outras entradas físicas;

- os produtos e as emissões atmosféricas, os efluentes líquidos, os resíduos sólidos e outros aspectos ambientais

Para a realização da análise de ICV, os procedimentos operacionais, como mostra a figura 16, são: a coleta dos dados; a alocação dos dados, em tabelas ou planilhas, e a validação das informações.

Os dados coletados devem ter base na unidade funcional e serem representados pelos fluxos de referência. Eles são coletados de acordo com o objetivo do estudo; contudo sua qualidade é importante, pois é a base de toda a análise e, por isso, seguem alguns parâmetros, de acordo com ISO (1998) e ABNT (2004a):

- cobertura temporal: a idade desejada dos dados (por exemplo, datados de até 5 anos) e o período mínimo de tempo indicado para a coleta dos dados (por exemplo, 1 ano de amostragem); 
- cobertura geográfica: área geográfica indicada para a coleta dos dados dos processos elementares, a fim de serem geograficamente compatíveis com os objetivos do estudo (por exemplo, local, regional, nacional, continental ou global);

- cobertura tecnológica: combinação de tecnologias e identificação das diferenças tecnológicas para os processos estudados (por exemplo, média ponderada da combinação dos processos existentes, melhor tecnologia disponível ou pior unidade em operação).

A coleta dos dados, neste trabalho, é desenvolvida a partir de uma ampla revisão bibliográfica sobre os temas envolvidos: coleta de dados dos processos agrícolas tradicionais em algumas fazendas produtoras de cana-deaçúcar da região de Ribeirão Preto, SP, e de destilarias-padrão de álcool da região de Ribeirão Preto, SP; da literatura técnica especializada e do banco de dados do EDIP. O banco de dados do EDIP foi disponibilizado durante o estágio na DTU, com a utilização do software SIMAPRO.

A análise de inventário se concentra na busca dos dados das maiores quantidades utilizadas no ciclo e dos aspectos de grande potencial de impacto ambiental, estratégia que Krozer e Vis (1998) também realizaram.

Após realizado o inventário, inicia-se a principal fase da ACV para a área ambiental: a Avaliação de Impactos do Ciclo de Vida (AICV). 


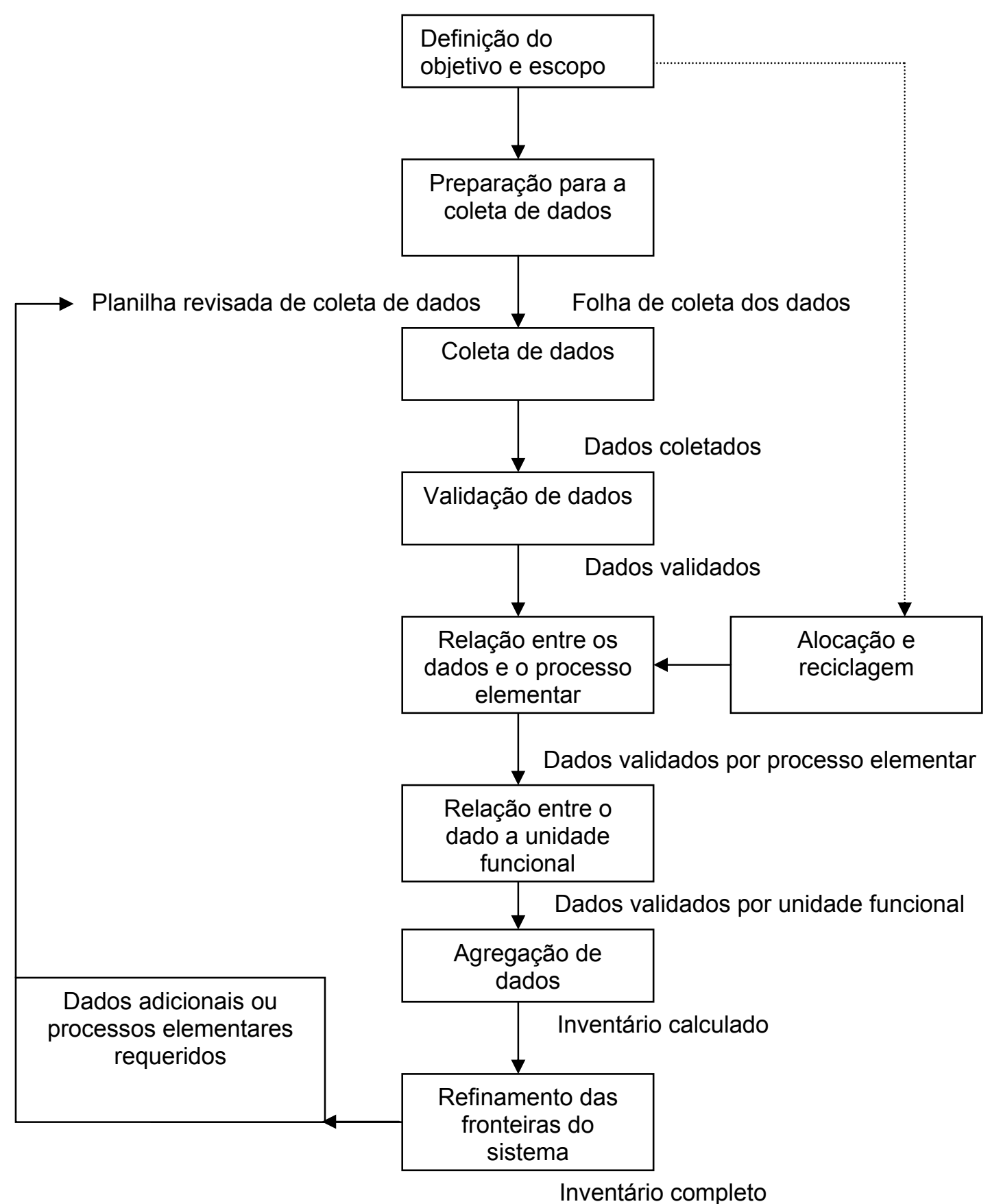

Figura 16 - Procedimentos simplificados para a análise do inventário Fonte - ISO (1998); ABNT (2004a) 


\subsection{Avaliação de impactos do ciclo de vida}

A AICV é definida, pela ISO (2000a), como um processo qualitativo e/ou quantitativo para classificar, caracterizar e analisar os efeitos das interações ambientais identificados na análise do inventário.

O objetivo da AICV, segundo ABNT (2004b), é avaliar o sistema de produto sob uma perspectiva ambiental, com o uso de categorias de impacto e de indicadores de categoria associados aos resultados do ICV.

Assim, esta fase determina a importância relativa de cada item do inventário e agrega seu potencial de impacto estabelecido. Para Udo de Haes et al. (2002), esta fase avalia a significância das intervenções ambientais contidas no inventário do ciclo de vida.

A estrutura geral da AICV é composta de três elementos obrigatórios, que convertem os resultados do ICV em indicadores por categoria de impacto. Adicionalmente, há os elementos opcionais para a normatização, o agrupamento e a ponderação dos resultados dos indicadores e técnicas de análise da qualidade dos dados. Os elementos obrigatórios da AICV, segundo ISO (2000a) e ABNT(2004b), são:

- Seleção das categorias de impacto, indicadores de categoria ${ }^{18}$ e modelos de caracterização: nessa etapa, ocorre a identificação das categorias de impactos, dos indicadores das categorias e dos modelos de caracterização das categorias de impactos;

- Classificação: alocação dos resultados da análise de inventário nas categorias de impactos, correlacionando os resultados do ICV às categorias de impacto correspondentes;

- Caracterização: cálculo dos resultados dos indicadores da categoria.

Os métodos utilizados e suas aplicações, de acordo com a estrutura estabelecida em ISO (2000a) e ABNT(2004b), são descritos a seguir.

\footnotetext{
${ }^{18}$ Indicador de categoria de impacto do ciclo de vida é a representação quantificável de uma categoria de impacto (ABNT, 2004b).
} 


\subsubsection{EDIP}

As categorias de impacto, os modelos de caracterização e os indicadores de categorias para o método EDIP baseiam-se em Wenzel et al. (1997). Dentre as categorias indicadas pelo EDIP, as selecionadas para este estudo são:

- Consumo de recursos:

- Renováveis;

- Não-renováveis;

- Energia.

- Potenciais de impactos ambientais:

- Potencial de aquecimento global;

- Potencial de formação fotoquímica de ozônio troposférico;

- Potencial de acidificação;

- Potencial de eutrofização;

- Potencial de ecotoxicidade e

- Potencial de toxicidade humana.

Antes de apresentar o método das avaliações das categorias de impactos pelo EDIP, é importante definir os conceitos, de acordo com Wenzel et al. (1997), das escalas de abrangência espacial (local, regional ou global) dos efeitos dos impactos.

Impactos de efeitos locais são os que ocorrem sobre fontes individuais significativas. Impactos locais são limitados pela vizinhança imediata da fonte ou da influência do impacto, sendo o efeito, normalmente, no máximo no raio de alguns quilômetros.

Impactos regionais são os impactos que causam efeitos em uma área de 100 a $1000 \mathrm{~km}$ de raio, o que dependerá da natureza do impacto e de sensibilidade do ambiente. Em contraste com impactos locais, impactos ambientais regionais normalmente são causados por fontes difusas, isto é, não podem ser rastreados até se indicar um ponto específico gerador. Isso se deve 
ao fato de que a fonte está distante dos efeitos ou porque os efeitos são conseqüências de uma interação de diversas pequenas fontes geradoras de impactos. Em uma escala regional, em comparação aos efeitos globais, mais substâncias de curta vida podem contribuir para efeitos ambientais.

Impactos globais são os impactos que influenciam toda a Terra. Segundo Wenzel et al., 1997, as substâncias que causam impactos de efeitos globais apresentam as seguintes características:

- vida longa no ambiente, dispersando-se muito, antes de serem degradadas ou estabilizadas;

- alta mobilidade no ambiente, atingindo todas as partes do ambiente global, incluindo aquelas sensíveis aos seus impactos.

As substâncias de efeito global são, freqüentemente, emitidas em grandes quantidades, podendo, apesar de sua diluição durante a dispersão, causar efeitos sentidos globalmente.

As categorias de impactos, segundo o EDIP, são apresentadas a seguir, segundo Wenzel et al. (1997):

\section{Consumo de recursos}

A classificação e a caracterização para a categoria consumo de recursos são realizadas pela alocação direta dos resultados da ICV com relação à quantidade de recursos naturais, dividindo-os em recursos não renováveis, renováveis e energia.

\section{Renováveis}

Os recursos renováveis são definidos como os que podem ser regenerados e que não serão, necessariamente, esgotados pela exploração humana, considerados de escala regional ou local, podendo variar dependendo do recurso e do processo de extração.

\section{Não-Renováveis}

Os recursos não-renováveis são definidos como os que não são regenerados, ou que são regenerados a uma taxa praticamente insignificante 
frente à sua quantidade disponível. Os recursos não-renováveis apresentam efeitos de escala global de abrangência espacial.

\section{Energia}

O consumo de energia, normalmente, apresenta a escala de impacto regional; contudo depende da forma de produção da energia utilizada.

\section{$\underline{\text { Potenciais de impactos ambientais }}$}

Para as categorias de potenciais de impactos ambientais, a classificação dos resultados de saídas da ICV, nas categorias de impacto, está tabelada, por substância química, em Wenzel et al. (1997).

A partir da classificação, a caracterização é realizada por meio da multiplicação dos resultados de saídas da ICV, classificados nas categorias de impactos, pelos seus respectivos fatores de caracterização, de acordo com 0 EDIP, em Wenzel et al. (1997).

O resultado do indicador de impacto é apresentado em termos da unidade do fator de caracterização para cada categoria de impacto. Por exemplo, para o aquecimento global, o indicador é a quantidade de dióxido de carbono equivalente $\left(\mathrm{CO}_{2}\right.$ eq.).

\section{Potencial de aquecimento global}

Segundo Wenzel et al. (1997), a atmosfera da Terra absorve parte da energia emitida como radiação infravermelha e se esquenta. Tal efeito de aquecimento natural da Terra vem-se intensificando nos últimos séculos pelas atividades humanas, levando à acumulação demasiada dos gases que aprisionam o calor na Terra. As conseqüências desse acúmulo ocasionado pelo Homem são de efeito global e podem incluir o aumento da temperatura média global e mudanças climáticas regionais repentinas.

Para a substância ser considerada como causadora de efeito estufa, ela precisa ser um gás, nas condições normais de temperatura e de pressão, e apresentar, no mínimo, uma destas duas características:

- ser capaz de absorver radiação infravermelha e ser estável na atmosfera com tempo de residência de anos a séculos; 
- ser de origem fóssil e convertido em $\mathrm{CO}_{2}$ na degradação para a atmosfera.

Os potenciais de aquecimento global, apresentados na tabela 2, convergem para os resultados do Intergovernamental Panel on Climate Change (IPCC), em Albritton et al. (1995), os quais são baseados em modelos de simulação do comportamento dos gases na atmosfera por um longo período. Tais resultados expressam o potencial de aquecimento global de uma determinada quantidade de gás relativa à contribuição da correspondente quantidade de $\mathrm{CO}_{2}$ para este efeito e são apresentado em Wenzel et al. (1997, p.247).

Tabela 2 - Fatores de equivalência de alguns gases para a caracterização do potencial de aquecimento global

\begin{tabular}{|c|c|c|c|c|}
\hline Substância & Fórmula & \multicolumn{4}{|l|}{ Fatores de caracterização (gco2 eq. $\mathbf{g}$ subst. $)$} \\
& química & $\mathbf{2 0}$ anos $\mathbf{1 0 0}$ anos $\quad \mathbf{5 0 0}$ anos \\
\hline Dióxido de carbono & $\mathrm{CO}_{2}$ & 1 & 1 & 1 \\
\hline Metano & $\mathrm{CH}_{4}$ & 62 & 25 & 8 \\
\hline Monóxido de carbono & $\mathrm{CO}$ & 2 & 2 & 2 \\
\hline Óxido de Nitrogênio & $\mathrm{N}_{2} \mathrm{O}$ & 290 & 320 & 180 \\
\hline
\end{tabular}

Fonte: Wenzel et al. (1997).

O aquecimento global é um impacto considerado global e o resultado do indicador é expresso em quantidade de dióxido de carbono equivalente ou gás carbônico equivalente $\left(\mathrm{CO}_{2 \text { eq. }}\right)$. O resultado, portanto, representa o potencial total de impacto de aquecimento global que essa quantia de $\mathrm{CO}_{2}$ causaria.

\section{Potencial de formação fotoquímica de ozônio troposférico}

De acordo com Wenzel et al. (1997), quando solventes e outros compostos orgânicos voláteis são emitidos na atmosfera, eles são freqüentemente degradados em alguns dias pela reação de oxidação, a qual ocorre sob a influência da luz do sol. Na presença de óxidos de nitrogênio (NOx), o ozônio pode ser formado. Os óxidos de nitrogênio não são 
consumidos durante a formação do ozônio, mas desempenham a função de catalisadores.

Os compostos orgânicos voláteis são "quebrados" ou separados quimicamente, especialmente, na troposfera, a região mais baixa da atmosfera, para onde eles são emitidos. As principais fontes antrópicas desses compostos são o diesel e o petróleo parcialmente queimados e o uso de solventes orgânicos, como em pinturas.

O ozônio gera aumento na freqüência de problemas respiratórios no Homem, redução na produtividade agrícola (na Dinamarca, a estimativa conservadora dessa redução atinge $10 \%$ da produção total), sendo um impacto que afeta o ambiente em escala local e regional.

A substância de referência, assim como a unidade para tal impacto, é o eteno $\left(\mathrm{C}_{2} \mathrm{H}_{4}\right)$, representando o potencial de formação fotoquímica de ozônio troposférico que seria causado pelo eteno.

Os fatores de caracterização para a formação fotoquímica de ozônio troposférico são calculados a partir da relação entre a contribuição dos gases para formação de ozônio e a do eteno. Os resultados das contribuições desses gases são obtidos a partir de modelos químicos atmosféricos e de considerações desse efeito nas áreas com alta e baixa concentração de NOx de acordo com Andersson-Sköld et al. (1992) e Derwent e Jenkin (1990).

Segundo Wenzel et al. (1997), para a modelagem do cálculo dos fatores de caracterização do potencial de formação fotoquímica de ozônio troposférico é necessário a escolha da escala temporal. Os valores calculados para o período de 24 horas descrevem os potenciais correspondentes a vizinhança imediata do local onde ocorre a emissão. Para períodos maiores, como uma semana, a maioria dos compostos orgânicos voláteis terá suas ligações químicas quebradas e os valores obtidos apresentam uma expressão melhor do potencial total da formação de ozônio. Os fatores de caracterização apresentados em Wenzel et al. (1997, p.252-253) são calculados para um período intermediário de 4 a 5 dias. 


\section{$\underline{\text { Potencial de acidificação }}$}

Segundo Wenzel et al. (1997), quando ácidos e outros compostos que podem ser convertidos em ácidos são emitidos na atmosfera e depositados na água e no solo, a adição do cátion de hidrogênio pode resultar em redução do $\mathrm{pH}$ e, conseqüentemente, em aumento da acidez.

A acidificação apresenta, como conseqüências, de acordo com Wenzel et al. (1997), grande declínio nas florestas, como registrado na Europa e nos Estados Unidos, em florestas de coníferas; mortandade de peixes, como registrado nos lagos da Escandinávia e da Europa Central; corrosão de metais e desintegração de revestimento de superfícies metálicas e de materiais minerais de construção.

Uma das atividades humanas que mais causam a acidificação é o transporte, potencializado quando o combustível utilizado apresenta enxofre. Portanto, a unidade para tal impacto é o dióxido de enxofre equivalente $\left(\mathrm{SO}_{2}\right.$ eq. $)$, que representa a quantidade do efeito de acidificação relativo ao dióxido de enxofre.

O cálculo do fator de caracterização de acidificação de uma substância é baseado, segundo Wenzel et al. (1997), no número de íons de hidrogênio que podem ser liberados pela substância no ambiente, de forma direta ou após algumas conversões. Os resultados dos fatores de caracterização do potencial de acidificação das substâncias estão apresentados em Wenzel et al. (1997, p.256).

A acidificação é um impacto que afeta o ambiente, principalmente, em escala regional e pode ser causado por emissões no ar, na água e no solo.

\section{Potencial de eutrofização}

Segundo Wenzel et at. (1997), o enriquecimento abrupto de nutrientes, ou eutrofização, é um impacto em ecossistemas, a partir de substâncias que contenham nitrogênio $(N)$ ou fósforo $(P)$. Como regra, a disponibilidade de um desses nutrientes será um fator limitante para o crescimento no ecossistema e, se um desses nutrientes for adicionado, o crescimento de plantas e algas aumentará. 
Contudo, em ecossistemas aquáticos, o aumento demasiado de nutrientes pode causar situações de falta de oxigênio nas camadas inferiores, devido ao aumento demasiado no crescimento das algas e, conseqüentemente, à decomposição das algas no fundo. No solo, ecossistemas naturalmente pobres em nutrientes estão gradualmente desaparecendo como resultado da adição de nitrogênio.

A principal fonte de nitrogênio para o ambiente aquático é, normalmente, o uso de fertilizantes na agricultura; contudo óxidos de nitrogênio advindos de processos de combustão também são fontes importantes da eutrofização aquática e terrestre.

Para o fósforo, o uso de fertilizantes na agricultura também é apontado como a grande fonte geradora, podendo, em alguns casos, advir, entre outros, de sistemas de tratamento de esgoto urbano e de efluente industrial.

A eutrofização é um impacto que pode ser causado por emissões no ar, na água e no solo, sendo seus efeitos ocasionados em ambientes aquáticos e terrestres em escalas locais e regionais.

A avaliação de tal impacto é realizada com base no nitrogênio, sendo a unidade de referência a quantidade de $\mathrm{N}$; no fósforo, sendo a unidade de referência a quantidade $\mathrm{P}$ e no efeito sinérgico do $\mathrm{N}$ e do $\mathrm{P}$ pela combinação de ambos, sendo a unidade de referência, neste caso, a quantidade de nitrato equivalente $\left(\mathrm{NO}_{3}{ }^{-}\right.$eq. $)$.

Os fatores de caracterização para o potencial de eutrofização são calculados para as substâncias que contenham nitrogênio $(N)$ ou fósforo $(P)$ a partir da forma como esses elementos são biologicamente disponíveis. Para o cálculo do efeito conjunto dos elementos, como o $\mathrm{N}$ se apresenta nos organismos aquáticos, normalmente, dezesseis vezes mais que o $\mathrm{P}$, o peso do potencial do $\mathrm{P}$ é calculado como 16 vezes maior. Os valores dos fatores de caracterização do potencial de eutrofização são apresentados em Wenzel et al. (1997, p.258). 


\section{Potencial de ecotoxicidade}

Segundo Wenzel et at. (1997), as substâncias químicas emitidas pelas atividades antrópicas podem contribuir para a ecotoxicidade, se elas afetarem, devido a seus efeitos tóxicos, os organismos vivos, a função e a estrutura do ecossistema.

Dependendo da concentração da emissão da substância perigosa à vida no ambiente, os efeitos tóxicos podem ocorrer assim que as substâncias são emitidas, ocasionando a ecotoxicidade aguda, o que, freqüentemente, resulta na morte dos organismos expostos.

Efeitos tóxicos que não são instantaneamente letais e que aparecem após exposições repetidas às substâncias perigosas, ou em longo prazo de tempo, constituem a ecotoxicidade crônica. A ecotoxicidade crônica de um composto é determinada pela sua toxicidade, sua biodegradabilidade e sua habilidade em se acumular em organismos vivos. Os efeitos da ecotoxicidade crônica podem ser, por exemplo, a redução da capacidade reprodutiva de espécies.

Ecotoxicidade é um impacto que, predominantemente, afeta o ambiente em escala local e regional. Em alguns casos em que a substância tóxica apresenta um grau de biodegradabilidade muito baixo e uma forte tendência a se acumular em organismos vivos, o impacto pode ser considerado de escala global.

Os fatores de caracterização da ecotoxicidade, segundo Wenzel et al. (1997), são determinados pelo produto de três componentes: a dispersão da substância no ambiente, a característica ecotoxicológica e a biodegradabilidade. Esses resultados dependem exclusivamente das características da substância, independente do contexto onde a emissão ocorre. Os fatores de caracterização da ecotoxicidade são apresentados em Wenzel et al. (1997, p.261-263).

Os compartimentos ambientais finais dos efeitos de ecotoxicidade das emissões no ar, na água e no solo são a água e o solo. A unidade de referência para a ecotoxicidade é o volume do respectivo compartimento (água ou solo) necessário para neutralizar ou diluir a substância tóxica, de modo a 
sua concentração ser baixa o bastante para não causar efeitos ecotoxicológicos. Os impactos podem ser avaliados de acordo com os efeitos das emissões na água, de modo crônico e agudo, e no solo, de modo crônico.

\section{Potencial de toxicidade humana}

Segundo Wenzel et al. (1997), a toxicidade humana é ocasionada pelas atividades antrópicas que emitem substâncias químicas com alto teor venenoso que atingem o Homem através do ambiente. Isso ocorre devido às características das substâncias, em combinação com o modo de emissão. As rotas mais importantes são a respiração (via ar) ou materiais ingeridos, como o alimento.

Assim como a ecotoxicidade, a toxicidade humana pode ter efeitos agudos ou crônicos, dependendo da concentração da emissão. A toxicidade crônica é, freqüentemente, causada por substâncias que apresentam um baixo grau de degradabilidade no ambiente e, portanto, que permanecem um período de tempo longo após a emissão. Algumas substâncias apresentam, também, a tendência a se acumular nos organismos vivos que servem de alimentos para o Homem. Portanto, a toxicidade humana é causada por substâncias que apresentam características tóxicas, não biodegradáveis e concentradas nos organismos vivos.

A toxicidade humana é um impacto que afeta humanos no ambiente em escala local e regional. Para algumas substâncias, cujas ligações dificilmente são rompidas, facilmente transportadas e venenosas, a toxicidade humana pode ser considerada de efeito global.

Os fatores de caracterização da toxicidade humana, segundo Wenzel et al. (1997), são determinados pelo produto de cinco componentes: a dispersão da substância no ambiente, a transferência da substância pela rota de exposição, o fator de inalação ou ingestão da substância, a toxicidade e a biodegradabilidade da substância. Os resultados dos fatores de caracterização da toxicidade humana de noventa substâncias são apresentados em Wenzel et al. (1997, p.281-283) e dependem exclusivamente das características da substância, independente do contexto onde a emissão ocorre. Tais resultados são, assim como os fatores do potencial de ecotoxicidade, a base do guia 
técnico da comissão da União Européia sobre avaliação de riscos de substâncias químicas no ambiente, publicado em European Commission (1996). O fator de caracterização do potencial de toxicidade humana do material particulado foi avaliado pela via aérea, de acordo com o estudo para bioenergia na Europa, em Calzonid et al. (2000).

Os compartimentos ambientais, por meio dos quais o Homem se expõe às substâncias tóxicas, são: o ar, a água e o solo. Portanto, a unidade de referência para a toxicidade humana é o volume do respectivo compartimento (ar, água ou solo) necessário para neutralizar ou diluir a substância tóxica, de modo a sua concentração ser baixa o bastante para não causar efeitos tóxicos ao Homem.

Krozer e Vis (1998) afirmam que as classificações de impactos para a elaboração da AICV devem ser focadas nos materiais emitidos em grande quantidade e nos de grande potencial de impacto. Para isso, recomendam a definição de um número limitado de categorias de impactos.

Ainda para a fase de AICV, neste estudo do álcool combustível, além do EDIP, as avaliações do impacto das emissões atmosféricas e dos insumos do ciclo de vida do álcool combustível hidratado foram realizadas por meio de dois métodos: a Exergia e a Emergia, respectivamente. De modo a atender aos objetivos deste estudo, a emergia e a exergia são aplicadas, também, como métodos de valoração ambiental.

\subsubsection{Exergia}

Segundo Horlock (1997) e Campo (1999), a maneira mais difundida de se calcular a eficiência ou o desempenho de um processo de conversão de energia é a análise energética baseada na primeira lei da Termodinâmica. Contudo, segundo Tsatsaronis em Torres (1999) e Giannantoni (2002), algumas limitações da análise pela primeira lei para processos produtivos, podem ser indicadas:

a) a primeira lei não determina quanto de energia de um fluxo é disponível para o trabalho mecânico; 
b) pela primeira lei, não é possível quantificar as perdas de energia, pois ela se transforma em uma de suas duas formas: calor ou trabalho.

Segundo Torres (1999), ao analisar uma planta térmica que produz calor e trabalho, como a cogeração de energia elétrica no ciclo de vida do álcool, pela primeira lei, identifica-se que o condensador é o grande responsável pela baixa eficiência do sistema. Entretanto a análise pela segunda lei da Termodinâmica permite verificar que as maiores perdas acontecem na caldeira.

Para quantificar a primeira lei da Termodinâmica em um volume de controle em regime permanente, desprezando-se as variações de energia cinética e potencial, tem-se a eq. (6), dada por Moran e Shapiro (1995):

$$
\dot{Q}-\dot{W}+\sum \dot{m}_{e} h_{e}-\sum \dot{m}_{s} h_{s}=0
$$

onde:

$$
\begin{aligned}
& \dot{Q}=\text { fluxo de calor; } \\
& \dot{W}=\text { potência; } \\
& \dot{m}=\text { fluxo mássico; } \\
& \text { h = entalpia; } \\
& \text { e (subscrito) = entrada; } \\
& \text { s (subscrito) = saída. }
\end{aligned}
$$

Segundo Kotas (1995), Bejan et al. (1996) e Yantovskii (1994), diferentemente da primeira lei, a Exergia não é conservativa, pois parte dela é perdida devido às irreversibilidades internas do sistema e à perda entrópica nos processo termodinâmicos.

De acordo com Wark (1995), Szargut et al. (1988), Kotas (1995), Cornelissen (1997), Rosen e Dincer (1999) e Bejan (1988), a Exergia é fundamentada na segunda lei da Termodinâmica e pode ser definida como a quantidade máxima de trabalho mecânico internamente reversível, disponível em um fluxo de matéria ou energia, quando estes se deslocam de um estado de desequilíbrio físico e/ou químico para o ambiente-padrão de referência, trocando calor somente com o ambiente. $O$ estado-padrão do ambiente de 
referência, ou estado de referência, é estabelecido pela temperatura, pela pressão e pela composição química do ambiente. Usualmente, são utilizadas as condições normais de temperatura e de pressão (CNTP) de $25^{\circ} \mathrm{C}$ e $1 \mathrm{~atm}$, respectivamente, e a composição química mais estável do ambiente, a da atmosfera.

Algumas outras definições para o termo Exergia, também chamado disponibilidade (availability), são apresentados a seguir:

- Wark (1995) define como o máximo trabalho útil internamente reversível que pode ser obtido da interação sistema-atmosfera, com o sistema passando de um estado físico e químico específico para o estado padrão do ambiente de referência (à $\mathrm{T}_{0}=25^{\circ} \mathrm{C}$ e $\mathrm{P}_{0}=1 \mathrm{~atm}$ e composição química padrão), trocando calor somente com o ambiente;

- Szargut et al. (1988) definem-na como aquela fração de energia que pode ser convertida em trabalho mecânico, à medida que um sistema se dirige para o seu estado final de equilíbrio físico-químico com o ambiente. Ou ainda, como a quantidade de trabalho mecânico que pode ser obtida quando um fluxo se equilibra termodinamicamente com os componentes do ambiente, por meio de processos reversíveis, envolvendo interações físicoquímicas somente entre o fluxo e o ambiente;

- segundo Kotas (1995), Exergia é o padrão de qualidade da energia, igual ao máximo trabalho útil que pode ser obtido de uma dada forma de energia, utilizando os parâmetros do ambiente $\left(P_{0}, T_{0}\right)$ como referência;

- para Tsatsaronis, em Torres (1999), a Exergia é o máximo trabalho útil que pode ser obtido de um portador de energia, quando este seja levado até as condições do ambiente num processo reversível.

Segundo Kotas (1995), Bejan et al. (1996) e Szargut (1999), a Exergia total de uma substância pode ser dividida em: cinética, potencial, física (temperatura e pressão) e química. A Exergia cinética pode ser calculada pelo significado da velocidade em relação à superfície da Terra e a potencial pelo nível da vizinhança com relação ao sistema considerado. A Exergia física resulta da diferença de temperatura e de pressão em relação ao ambiente e a 
química, da diferença entre a composição química dos componentes do sistema e a composição padrão do ambiente de referência.

A equação geral da Exergia física de um fluxo, segundo Kotas (1995) e Wark(1995), é a eq. (7):

$$
\dot{E}_{x}=\left(h-h_{o}\right)-T_{o}\left(s-s_{o}\right)
$$

onde "h" é a entalpia, "s" a entropia do fluxo, $\mathrm{T}_{\mathrm{o}}$ a temperatura do ambiente de referência-padrão. O subíndice "o" refere-se às condições do ambiente de referência-padrão $\left(T_{0}=25^{\circ} \mathrm{C}\right.$ e pressão do ambiente, $\left.P_{o}=1 \mathrm{~atm}\right)$.

O balanço de Exergia física para o volume de controle, em regime permanente, segundo Kotas (1995) e Wark(1995), é dado pela eq. (8):

$$
\sum_{i} \dot{Q}\left(1-\frac{T_{o}}{T_{i}}\right)-\dot{W}_{v c}+\sum_{e} \dot{m}\left[h+\frac{V^{2}}{2}+g z-T_{o} s\right]-\sum_{s} \dot{m}\left[h+\frac{V^{2}}{2}+g z-T_{o} s\right]-T o \sigma=0
$$

onde:

$\sum_{i} \dot{Q}\left(1-\frac{T_{o}}{T_{i}}\right)$ : Exergia dos fluxos de calor que entram ou saem do volume de controle $[\mathrm{kJ}]$

$\dot{W}_{v c}$ : trabalho útil ou Exergia do volume de controle $[\mathrm{kJ}]$

$\sum_{e} \dot{m}\left[h+\frac{V^{2}}{2}+g z-T_{o} s\right]:$ Exergia dos fluxos de massa que entram no volume de controle [kJ] $\sum_{s} \dot{m}\left[h+\frac{V^{2}}{2}+g z-T_{o} s\right]:$ Exergia dos fluxos de massa que saem do volume de controle [kJ] $\sigma:$ entropia no volume de controle $[\mathrm{kJ}]$

$\mathrm{V}$ : velocidade $[\mathrm{m} / \mathrm{s}]$

g: aceleração gravitacional $\left[9,81 \mathrm{~m} / \mathrm{s}^{2}\right]$

$\mathrm{z}$ : altura [m] 
A Exergia química, por sua vez, é baseada no potencial químico da espécie e quanto mais ela se afasta de seu estado padrão no ambiente, maior é a Exergia química. Segundo Atkins (1994), o potencial químico é baseado na mudança da energia interna da substância, de acordo com sua quantidade ou concentração.

De acordo com Bejan et al. (1996) e Szargut (1999), a Exergia química expressa o valor exergético da substância, com temperatura e pressão já equilibrados com o ambiente, resultado da diferença da concentração da substância em relação à composição química do ambiente.

Dessa forma, para o cálculo da Exergia química, é necessário estabelecer o ambiente de referência, no qual as concentrações das espécies de referência são determinadas.

Diversos modelos de ambiente de referência para cálculo da Exergia química têm sido propostos, sendo utilizado neste trabalho o modelo de substâncias de referências usando o ambiente de referência padrão e os valores de Exergia química dados por Szargut et al. (1988). Tal uso se justifica pelo fato de o modelo ser um dos mais aceitos e utilizados pela comunidade científica internacional.

Segundo Szargut et al. (1988) e Rosen e Dincer (1997), o ambiente de referência atua como um sistema infinito, ou seja, um sumidouro de calor e de materiais. Considera-se que, nele, ocorram somente processos internamente reversíveis, cujo estado intensivo permanece inalterado, isto é, a temperatura, a pressão e os potenciais químicos de seus componentes permanecem constantes.

De acordo com Szargut et al. (1988), as espécies de referências gasosas são as mais convenientes para utilizar, porque suas concentrações na atmosfera podem ser medidas e são consideradas constantes (exceto para o vapor de água).

As Exergias químicas-padrões das espécies gasosas de referência, consideradas como gases ideais, são expressas pela eq. (9), segundo Szargut et al (1988): 


$$
\mathrm{b}_{\text {chref }}^{\circ}=\mathrm{RT}_{0}\left(\ln \mathrm{P}_{0} / \mathrm{P}_{00}\right)
$$

onde:

$\mathrm{R}$ : constante universal dos gases;

$\mathrm{T}_{0}$ : temperatura padrão de equilíbrio $\left(25^{\circ} \mathrm{C}\right)$;

$P_{0}$ : pressão ambiente padrão (1atm);

$\mathrm{P}_{00}$ : pressão do gás no ambiente de equilíbrio químico padrão restrito.

Pode-se calcular o valor da Exergia química padrão para qualquer composto pela sua reação de formação e com os dados de referência da Exergia química-padrão dos elementos químicos puros, pela eq. (10), dada por Szargut et al. (1988):

$$
b_{c h}^{\circ}=E_{f} G^{\circ}+\sum n_{e l} \cdot b_{c h \text { el }}^{\circ}
$$

onde:

$\mathrm{b}_{\mathrm{ch}}$ : Exergia química padrão do composto;

$E_{f} G^{\circ}$ : energia livre de Gibbs de formação padrão do composto;

$\mathrm{n}_{\text {el }}$ : número de moles do elemento no composto;

$\mathrm{b}_{\text {ch el }}^{\circ}$ : Exergia química-padrão dos elementos químicos puros.

Ainda de acordo com Szargut et al. (1988), considerando as concentrações ou pressões parciais médias convencionais das espécies de referência, quando grandes acuidades não são necessárias, a Exergia química de uma substância $\left(b_{c h}\right)$ é igual à sua Exergia química padrão (com exceção da água, $\mathrm{H}_{2} \mathrm{O}_{(l)}$ e do vapor $\left.\mathrm{H}_{2} \mathrm{O}_{(\mathrm{g})}\right)$. Tal consideração é representada pela eq. (11):

$$
\mathrm{b}_{\mathrm{ch}}=\mathrm{b}_{\mathrm{ch}}^{\mathrm{o}}
$$

Como uma das aplicações da Exergia na AICV do álcool combustível é feita pelo cálculo das Exergias químicas das principais emissões atmosféricas do ciclo de vida do álcool combustível, adotou-se a consideração dada pela eq. (11). 
Dessa forma, baseando-se em Szargut et al. (1988), a exergia química de cada substância emitida foi calculada pela eq. (12).

$$
b_{c h}=\left(b_{c h}^{o} / M M\right) \cdot 1000
$$

onde:

$b_{c h}$ : exergia química específica da substância $[\mathrm{kJ} / \mathrm{kg}]$

$b^{o}{ }_{c h}$ : exergia química-padrão específica da substância $[\mathrm{kJ} / \mathrm{g}]$

MM: Massa molecular da substância [g]

As exergias químicas específicas das principais substâncias emitidas no ciclo de vida do álcool são apresentadas na tabela 3.

Tabela 3 - Exergia química específica de algumas substâncias

\begin{tabular}{lr}
\hline Substância & $b_{\text {ch }}(\mathrm{kJ} / \mathrm{kg})$ \\
\hline $\mathrm{CO}_{2}$ & 451,49 \\
$\mathrm{NO}$ & $2.962,73$ \\
$\mathrm{CO}$ & $9.821,32$ \\
$\mathrm{SO}_{2}$ & $4.892,07$ \\
$\mathrm{HC}$ & $42.876,92$ \\
$\mathrm{NO}_{2}$ & $1.208,55$ \\
$\mathrm{SO}_{3}$ & $3.111,33$ \\
$\mathrm{Tolueno}$ & $42.797,07$ \\
$\mathrm{~N}_{2} \mathrm{O}$ & $2.428,84$ \\
$\mathrm{CH}_{4}$ & $51.838,71$ \\
\hline
\end{tabular}

Fonte: Szargut et al. (1988) .

Para o cálculo da Exergia (B) de cada substância emitida , multiplica-se a quantidade dada no ICV pela sua respectiva exergia química específica apresentada na tabela 3 , seguindo a eq. (13). 


$$
B=b_{c h} * Q_{e}
$$

onde: $Q_{\mathrm{e}}$ : quantidade da emissão atmosférica.

Complementando a avaliação exergética das emissões atmosféricas, é realizada a avaliação da Exergia físico-química da queimada da cana-deaçúcar, por meio do cálculo da exergia do combustível da palha da cana-deaçúcar. Com isso, é avaliado e valorado o impacto atmosférico físico-químico direto dessas emissões, em termos da quantidade de trabalho mecânico disponível.

O cálculo é realizado a partir da correlação do valor exergético de combustíveis sólidos com umidade, dada em Szargut et al. (1988), a partir das eqs. (14) e (15). Esse valor corresponde à Exergia física e química contida no combustível, que, nesse caso, é a palha da cana-de-açúcar.

$$
\text { ex palha }=\boldsymbol{\beta}_{\text {palha }}\left(P C I+h_{a} Z_{a}\right)+\operatorname{ex}_{a} Z_{a}
$$

onde:

$\beta_{\text {palha: }}$ razão em função das frações em massa, presente na palha, de hidrogênio, carbono, oxigênio e nitrogênio;

ex palha : Exergia específica da palha $[\mathrm{kJ} / \mathrm{kg}]$;

$\mathrm{ex}_{\mathrm{a}}$ : Exergia química específica da água líquida $[\mathrm{kJ} / \mathrm{kg}]$;

$h_{a}: \quad$ entalpia de vaporização da água líquida $[\mathrm{kJ} / \mathrm{kg}]$;

PCl: poder calorífico inferior da palha $[\mathrm{kJ} / \mathrm{kg}]$;

$Z_{\mathrm{a}}: \quad$ umidade da palha $[\%] ;$

$Z_{\mathrm{x}}$ : fração mássica dos elementos químicos da palha.

$$
\begin{aligned}
\beta_{\text {palha }} & =\frac{1.0412+0.2160 \frac{Z_{H 2}}{Z_{C}}-0.2499 \frac{Z_{O 2}}{Z_{C}}\left[1+0.7884 \frac{Z_{H 2}}{Z_{C}}\right]}{1-0.3035 \frac{Z_{O 2}}{Z_{C}}}+ \\
+ & \frac{0.0450 \frac{Z_{N 2}}{Z_{C}}}{1-0.3035 \frac{Z_{O 2}}{Z_{C}}}
\end{aligned}
$$


$\mathrm{Na}$ AICV deste trabalho, a exergia segue as orientações e os requisitos para a seleção de categorias de impacto, os indicadores de categoria e os modelos de caracterização de acordo com ISO (2000a) e ABNT (2004a).

A categoria de impacto para a aplicação da exergia, como método de AICV neste trabalho, é o impacto atmosférico físico-químico direto.

O indicador de categoria para o impacto atmosférico físico-químico direto é a perda de trabalho mecânico disponível, em quiloJoules (kJ), das emissões atmosféricas. O modelo de caracterização dessa categoria de impacto é dado pelo método da exergia.

A classificação para o impacto atmosférico físico-químico direto, modelado pela exergia, tem base nas emissões atmosféricas mais quantitativamente significativas no resultado do ICV.

A tabela 4 resume os componentes do mecanismo ambiental ${ }^{19}$ da AICV pela Exergia, baseados na estrutura da ISO (2000a) e ABNT (2004a).

Tabela 4 - Componentes do mecanismo ambiental da AICV pela Exergia

\begin{tabular}{ll}
\hline Componentes do mecanismo ambiental & Aplicação na Exergia \\
\hline Categoria de impacto & Impacto atmosférico físico-químico direto \\
Resultados do ICV & Emissões atmosféricas \\
Modelo de caracterização & Exergia \\
Indicador de categoria & Perda de trabalho mecânico \\
Fator de caracterização & Quantidade de trabalho mecânico disponível \\
& $\begin{array}{l}\text { do gás de acordo com suas propriedades } \\
\text { físico-químicas (kJ/kg gás) }\end{array}$ \\
Resultado do indicador & kJ (quiloJoules) \\
Ponto final da categoria & Atmosfera \\
Relevância ambiental & Espacial: global
\end{tabular}

\footnotetext{
${ }^{19}$ Mecanismo ambiental é definido como o sistema de processos físicos, químicos e biológicos para uma dada categoria de impacto, associando os resultados do ICV aos indicadores de categoria e ao ponto final da categoria (ABNT, 2004b).

${ }^{20}$ Fator de caracterização é definido como o fator derivado de um modelo de caracterização que é aplicado para converter os resultados associados do ICV à unidade comum do indicador de categoria (ABNT, 2004b).

${ }^{21}$ Ponto final da categoria é o atributo ou aspecto do ambiente natural, humano ou dos recursos, que identifica uma questão ambiental de relevância (ABNT, 2004b).
} 
Para a valoração ambiental, a exergia, por estar diretamente relacionada à produtividade e baseada em relações físico-químicas que descrevem a relação de causa e efeito das perdas de energia mecânica em processos produtivos, pode se enquadrar como um método de valoração direta. Tal valoração ocorre pelo valor de uso direto das emissões atmosféricas passíveis de serem convertidas em trabalho mecânico e que foram emitidas na atmosfera, gerando impactos físico-químicos diretos.

\subsubsection{Emergia}

O método da emergia, de acordo com Odum (1996), tem fundamentos na Termodinâmica, na Biologia, na Teoria Geral de Sistemas e Ecossistêmica, oferecendo um grande potencial de aplicações nas áreas ambientais e sociais. Junto com outras ferramentas científicas modernas, o método apresenta-se como uma alternativa para avaliar os sistemas atuais e planejar sistemas mais sustentáveis.

O método baseia-se na definição de Emergia, que, segundo Scienceman (1989) e Odum (1996), é toda energia disponível que foi utilizada para a obtenção de um produto, incluindo os processos da natureza e os humanos.

Essencialmente, Emergia pode ser concebida, como em Scienceman (1989), como a memória energética de um sistema, pois ela representa toda a energia incorporada de um sistema antrópico ou natural. Ou, ainda, segundo Collins e Odum (2001), é a energia requerida de um tipo para gerar energia de outros tipos.

Para Odum (1996) e Collins e Odum (2001), a análise emergética é um método de avaliação ecossistêmica que reconhece e mede a hierarquia universal da energia de acordo com suas transformações naturais ou influenciadas pelo Homem. Sua unidade é a energia solar equivalente (sej) ou emjoule (emj).

O método da emergia considera todas as fontes de energia externas ao ciclo (renováveis e não renováveis) que são consumidas em diferentes tipos de processos. Dessa forma, pode estabelecer a quantidade de energia usada em 
diferentes processos e obter uma assinatura energética, usada para comparar as eficiências de processos.

A representação gráfica das interações do sistema analisado com os recursos naturais e econômicos pode ser realizada por meio de diagramas sistêmicos.

Os diagramas sistêmicos são utilizados para possibilitar um melhor entendimento da função de cada componente do sistema e de suas interações. Esses componentes podem ser de origem natural, ou seja, os recursos naturais renováveis e não-renováveis, de origem econômica, dividida entre os materiais e os serviços, além da circulação do dinheiro no sistema. Os principais símbolos usados para a construção dos diagramas sistêmicos e suas definições estão apresentados nas figuras 17 e 18.

Nos diagramas, os elementos são organizados da esquerda para a direita, de acordo com a seqüência do processo e de sua transformidade. De acordo com Odum (1996), os elementos da esquerda apresentam menor energia incorporada (ou Emergia) que os da direita. Eles são construídos por blocos que representam os principais componentes do sistema e as entradas e as saídas de matéria e de energia. 
Circuito de Energia - o caminho do fluxo.

Fonte - Fonte externa de energia.

Tanque - Um compartimento que indica estoque de energia dentro de um sistema.

Dreno de Energia - Dispersão de energia potencial em calor que acompanha toda transformação ocorrida nos processos no estoque.

Interação - Interseção interativa de dois fluxos acoplados para produzir um fluxo de saída na proporção dada por uma função de ambos, controle de ação de um fluxo ou outro ; fator limitante de ação; estação de trabalho.

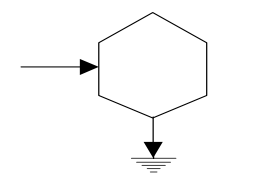

Consumidor - Unidade que transforma a qualidade de energia alimentada estocando-as realizando retro alimentação de maneira auto - catalítica para melhorar o fluxo de entrada.

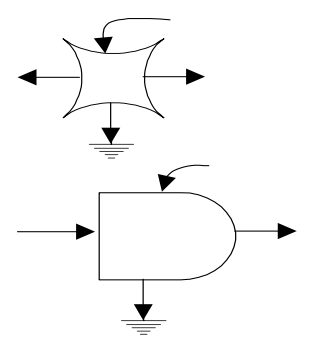

Chave - Símbolo que indica uma ação de conexão desconexão.

Produtor - Unidade que coleta e transforma energias de baixa qualidade em energias de alta - qualidade, usando interações de energia de forma controlada.

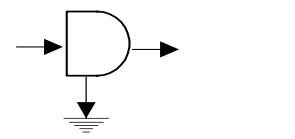

Receptor de Energia com auto - limitação - Uma unidade que tem uma limitação própria de saída quando os caminhos de entrada estão com a sua capacidade plena isto devido existência de uma limitação quantitativa para os matériais que podem reagir dentro de um circuito interno.

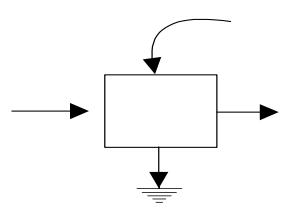

Caixa - Símbolo para usos variados. Indica uma unidade ou função usada num sistema.

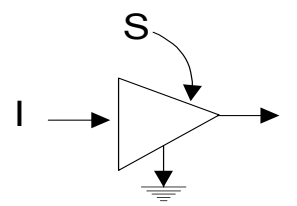

Amplificador - Uma unidade que fornece um fluxo de saída na proporção em que o fluxo de entrada (I) transformado por um fator constante contanto que a fonte de energia (s) seja suficiente.

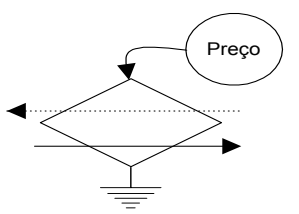

Transação - Uma unidade que indica a venda de produtos e serviços (linha cheia) em troca de pagamento em dinheiro (linha tracejada). O preço é mostrado como uma fonte de energia externa.

\section{Figura 17 - Símbolos emergéticos}

\section{Fonte - ODUM (1996)}




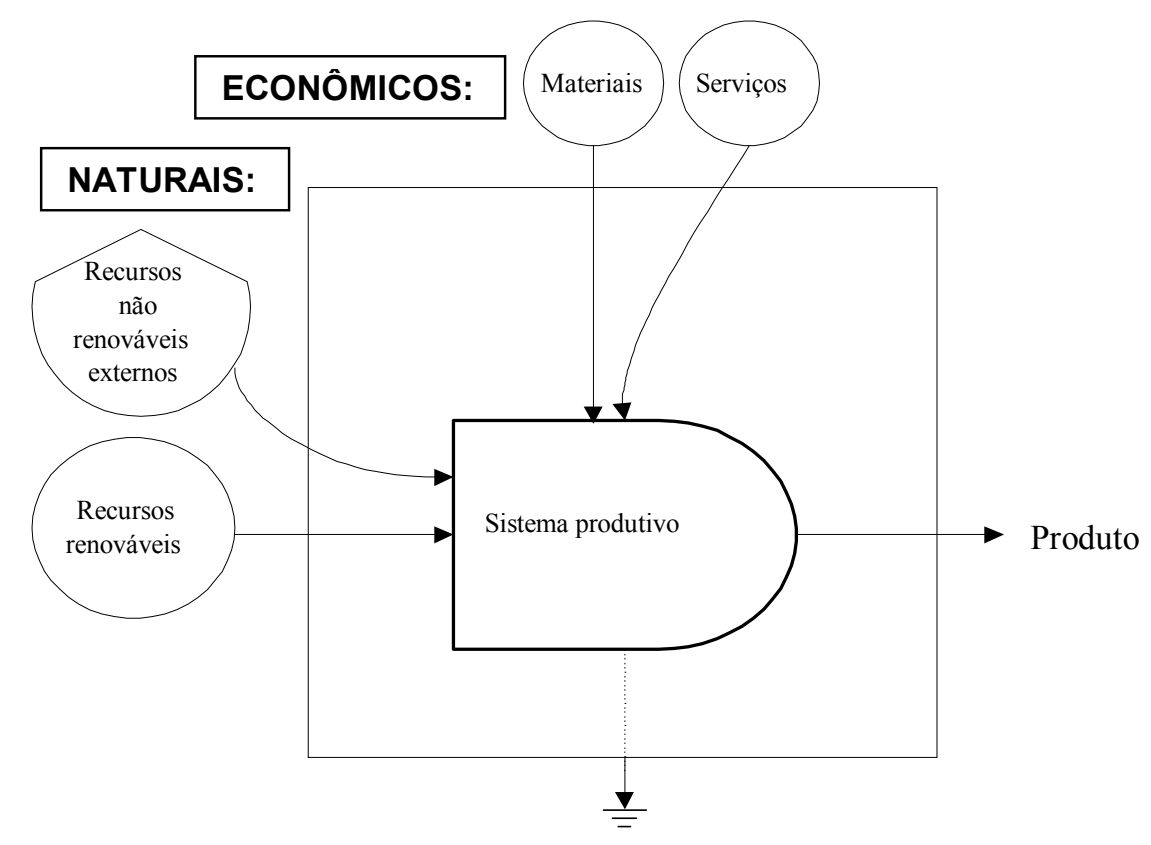

Fig. 18 - Representação gráfica de um diagrama sistêmico

Fonte - ODUM (1996)

Os diagramas auxiliam a visualização do sistema, a avaliação e os cálculos emergéticos dos seus componentes, ou seja, a energia solar incorporada de formação dos insumos utilizados no processo produtivo. Os cálculos são o centro do método e são realizados em planilhas, as quais são divididas em colunas, como mostrado na tabela 5 .

Tabela 5 - Elementos principais da planilha de cálculo emergético

\begin{tabular}{|l|l|l|l|l|l|l|l|l|}
\hline Referência & Recursos & Fluxo & Unidade & $\begin{array}{l}\text { Fluxos de energia } \\
\text { (J/ha.ano), } \\
\text { Massa (kg/ha.ano), } \\
\text { Dinheiro (US\$/ha.ano) }\end{array}$ & & & & \\
& & & & & & \\
& & & & & & \\
\hline
\end{tabular}

Para o preenchimento da tabela 5 , os dados utilizados seguem os procedimentos:

- Primeira coluna - o número de referência de cada um dos componentes, a fim de facilitar a rápida identificação do componente no memorial de cálculo. 
- Segunda coluna - destinada à inserção do nome do insumo ou do recurso utilizado.

- Terceira coluna - quantidades, em energia, massa ou valor monetário, de cada recurso.

- Quarta coluna - unidade do recurso que pode ser em Joules (J), em quilograma $(\mathrm{kg})$ ou em dólar (US\$).

- Quinta coluna - valores dos recursos são calculados para a unidade correspondente à transformidade.

- Sexta coluna - o valor da transformidade, de acordo com cada tipo de recurso e da unidade expressa na quinta coluna. Os valores da transformidade utilizados serão preferencialmente de Odum (1996).

- Sétima coluna - cálculo do fluxo de Emergia de cada recurso, obtido pela multiplicação da coluna cinco e seis.

- Oitava coluna - a percentagem de contribuição de Emergia de cada um dos recursos.

Na planilha emergética, há, também, divisões na horizontal, para facilitar a identificação dos tipos de recursos usados. Nas divisões superiores da tabela são colocados os insumos relacionados à contribuição da natureza (I), ou seja, os recursos naturais renováveis $(R)$ e os não-renováveis $(N)$. Abaixo, são colocados os recursos da economia $(F)$, divididos em materiais $(M)$ e serviços (S). E, no final, temos a Emergia total incorporada (Y).

O recurso utilizado no sistema, contabilizado em massa, energia ou dinheiro, é multiplicado pela transformidade do recurso, de modo a se calcular a Emergia incorporada. O somatório de todas as Emergias dos recursos indica o consumo total de energia solar equivalente do sistema.

Giannantoni (2002) identifica, como a álgebra emergética para o cálculo da Emergia, quatro regras fundamentais, sintetizadas também em Brown (1993):

1) para somente um fluxo de saída do volume de análise, este tem um total de Emergia igual à soma das Emergias dos insumos; 
2) em processos de cogeração, onde são gerados mais de um produto, cada produto tem a soma das Emergias dos insumos (para dois produtos, a Emergia total de saída é o dobro da Emergia de um produto);

3) quando o fluxo de saída de um processo se divide em fluxos separados, cada fluxo terá a Emergia proporcional à sua quantidade exergética;

4) Emergia não pode ser contabilizada duas vezes. Assim, não podem ser somadas as Emergias de subprodutos, quando reunidos, e as Emergias das reciclagens não são contadas novamente.

Tais regras são apresentadas pelas figuras 19, 20 e 21, representando, respectivamente, o balanço de Exergia, o balanço de Emergia e as transformidades calculadas pela razão entre a Emergia e a Exergia, segundo Brown e Herendeen (1996).

Segundo Giannantoni (2002), a segunda regra é a mais importante, pois demonstra que os subprocessos de cogeração são os maiores contribuintes para o aumento da Emergia em sistemas de organização própria. Esse aumento não tem efeito apenas nos fluxos de saídas dos componentes internos, mas também contribui (especialmente sob condições variáveis) para melhorar a organização e a estruturação do sistema como um todo.

As regras da álgebra emergética são decorrentes da definição da Emergia. Elas indicam que a Emergia é geralmente não-conservativa porque representa o aumento da qualidade em sistemas de organização própria.

De acordo com Giannantoni (2002), de modo geral, as regras são bem formadas e não totalmente arbitrárias, já que constituem o reflexo matemático dos aspectos fenomenológicos de processos produtivos, intrínsecos à natureza da própria organização dos sistemas. Isso faz com que se aprofunde o significado da Emergia, não somente no seu aspecto conceitual, mas também na sua natureza física. 


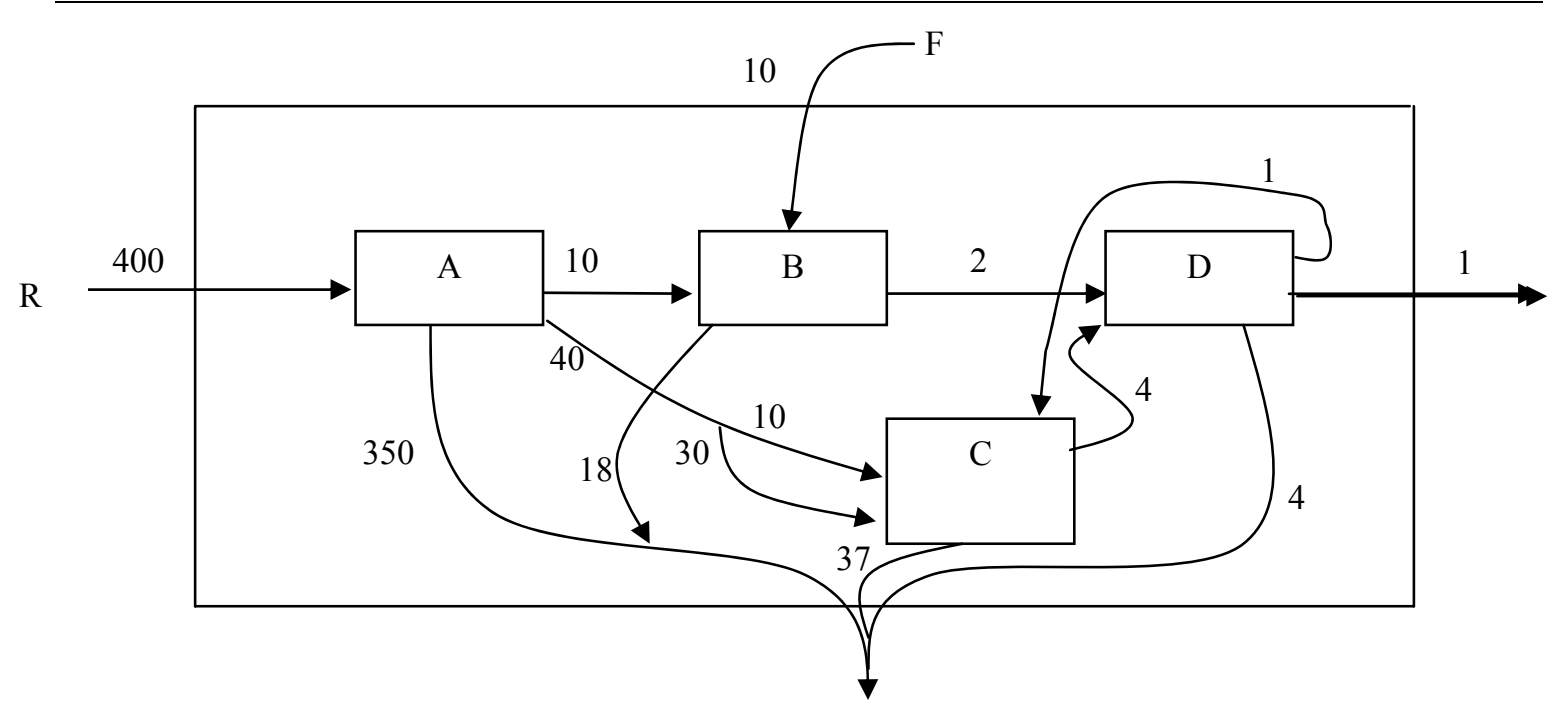

Figura 19 - Balanço de Exergia

Fonte - GIANNANTONI (2002)

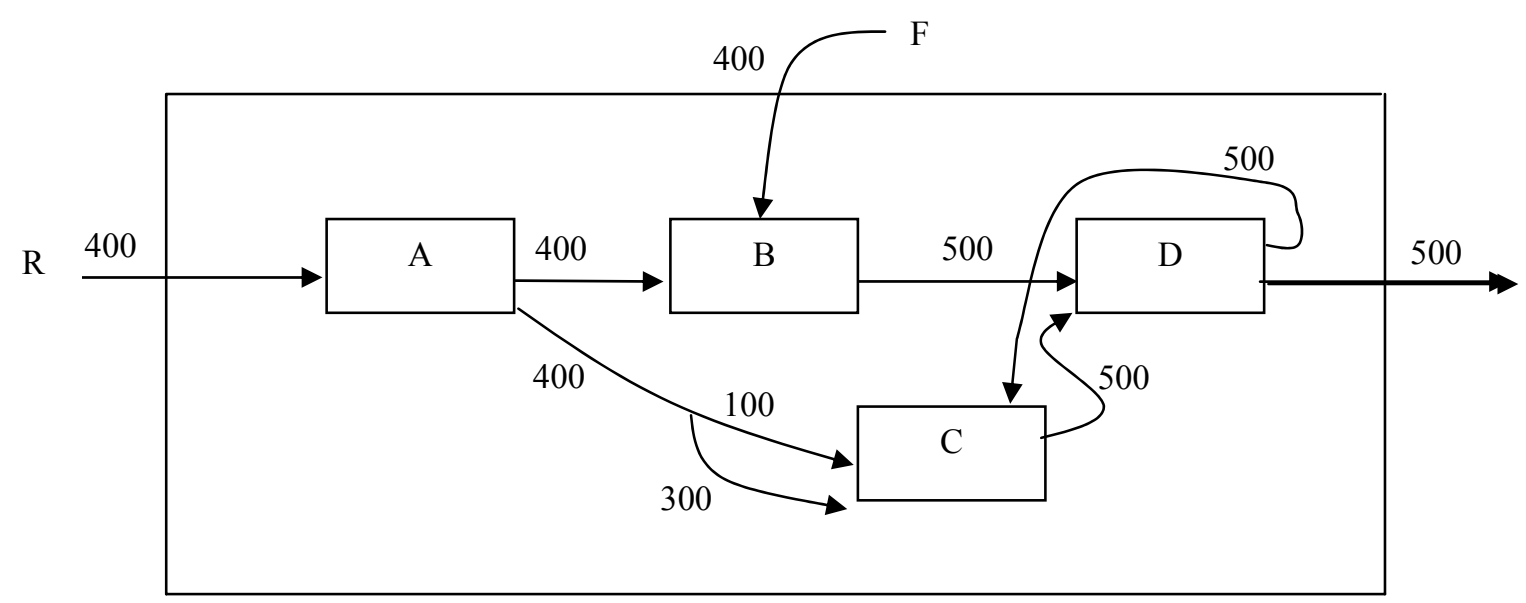

Figura 20 - Balanço de Emergia

Fonte - GIANNANTONI (2002)

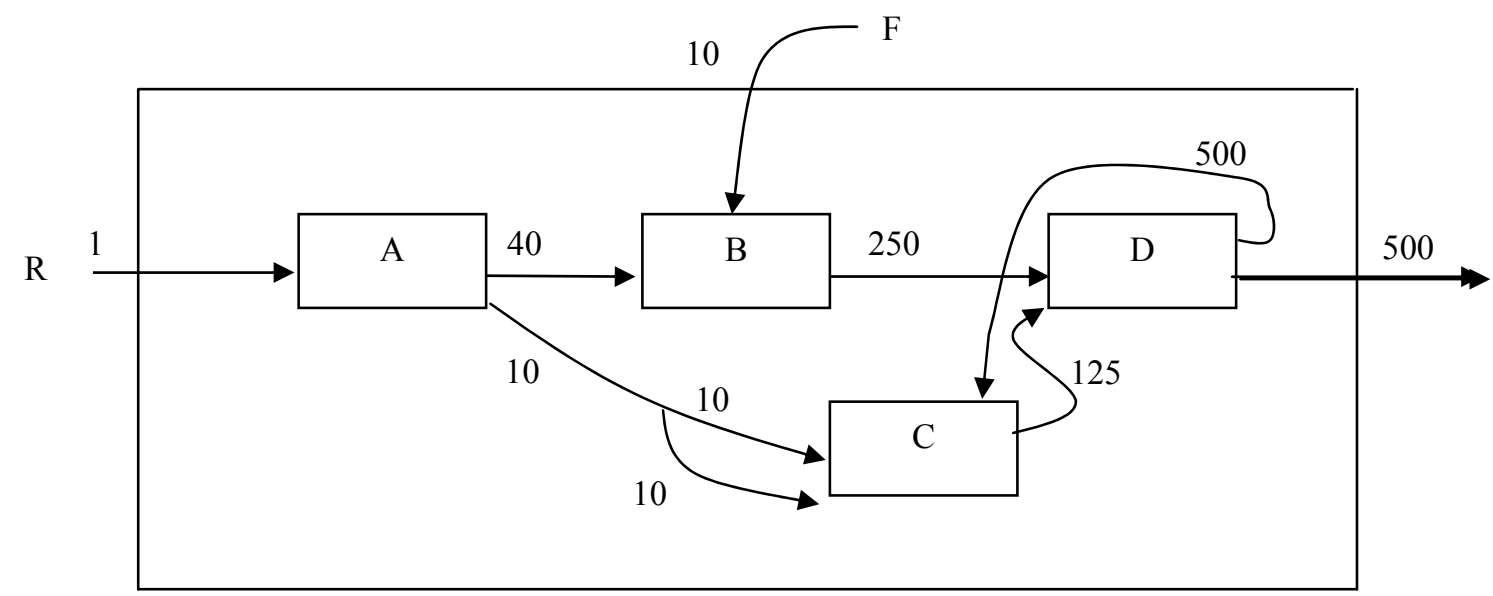

Figura 21 - Transformidades

Fonte - GIANNANTONI (2002); BROWN e HERENDEEN (1996) 
Segundo Odum (1996) e Comar (1999), é por meio dos Índices Emergéticos que o método desenvolve uma imagem dos fluxos dos recursos e dos serviços utilizados. A síntese dos resultados da avaliação emergética é, desse modo, representada por meio desses índices.

O índice mais importante é a Transformidade, fator de caracterização da categoria de impacto do consumo de energia solar equivalente.

A definição de cada índice e o procedimento de cálculo, de acordo com Odum (1996) e Ometto et al. (2003a), são indicados a seguir.

Transformidade (Tr): quantidade de energia solar equivalente incorporada nos processos de formação do elemento para produzir um produto ou um serviço.

A unidade deste índice é dada com base em energia (sej/J), em massa (sej/kg) ou em dinheiro (sej/US\$).

A transformidade é calculada pelo somatório das Emergias incorporadas nos insumos utilizados no processo, dividindo-se pela energia, pela massa ou pelo valor monetário do produto ou serviço.

Comparando-se dois produtos ou processos, quanto maior a transformidade, menor a eficiência ecossistêmica, pois foi necessário maior consumo de energia solar equivalente para a produção do bem.

Procedimento de cálculo:

$\operatorname{Tr}=\mathrm{Y} / \mathrm{Qp}$

Sendo:

$\mathrm{Y}=$ Emergia total dos insumos utilizados (unidade: sej);

$\mathrm{Qp} \mathrm{=} \mathrm{quantidade} \mathrm{energética} \mathrm{interna} \mathrm{total,} \mathrm{mássica} \mathrm{ou} \mathrm{monetária} \mathrm{contida}$ no produto (unidade: J, kg, US\$);

$Y=I+F$

I = Emergia dos Recursos Naturais (unidade: sej);

$\mathrm{F}=$ Emergia associada ao investimento econômico empregado ou a contribuição emergética advinda de materiais e de serviços obtidos do sistema econômico externo (unidade: sej). 
Eficiência Emergética (EYR): medida da contribuição dos recursos naturais frente aos recursos provenientes da economia. Portanto indica o grau da eficiência e da regeneração natural do processo analisado.

Segundo Comar (1999), representa a Emergia adicionada pelo sistema avaliado na economia regional. Portanto, quanto maior for este índice, maior é a eficiência natural do processo, mais regenerativo e menos dependente dos recursos econômicos.

Procedimento de cálculo:

$$
E Y R=Y / F
$$

Sendo :

$$
F=M+S
$$

$M=$ Emergia dos materiais utilizados (unidade: sej);

$S=$ Emergia dos serviços (unidade: sej).

Taxa de Investimento de Emergia (EIR): é a razão entre a contribuição da economia ou Emergia total dos recursos econômicos, que requerem dinheiro para sua aquisição, e a contribuição dos recursos naturais, quase sempre gratuitos. Este índice representa o investimento de materiais e de serviços da sociedade para produzir um bem, em relação à contribuição da natureza para essa produção. Pode ser visto, também, como o grau de dependência do sistema em relação aos recursos econômicos utilizados versus os naturais.

Um índice baixo indica que o ambiente provê mais recursos para o processo que a economia (materiais e serviços) e por isso, os custos de produção são menores.

As taxas de investimento de Emergia de alguns produtos naturais estão mostrados na tabela 6. Quanto maior o índice, maior a quantidade de recursos captados da economia, ou seja, mais Emergia externa foi utilizada para a transformação da matéria-prima e, provavelmente, mais etapas foram necessárias para viabilizar a comercialização do produto final. 
Tabela 6 - Taxa de investimento de Emergia de diversos produtos

\begin{tabular}{lc}
\hline Produto & EIR \\
\hline Madeira extraída de florestas tropicais & 0,14 \\
Arroz & 2,7 \\
Seda & 6,9 \\
Óleo de palmeira & 17 \\
Cacau & 17 \\
\hline
\end{tabular}

Fonte: ODUM (1996)

Procedimento de cálculo:

$E I R=F / I$

Sendo:

$\mathrm{I}=\mathrm{N}+\mathrm{R}$

$\mathrm{N}=$ Emergia dos recursos naturais não renováveis (sej);

$R=$ Emergia dos recursos naturais renováveis (sej).

Carga Ambiental (ELR): é a proporção da Emergia dos recursos nãorenováveis e os da Economia em relação à Emergia dos renováveis. É calculada pela divisão do somatório da Emergia dos recursos não-renováveis e dos obtidos da economia pela Emergia dos recursos renováveis.

Procedimento de cálculo:

$E L R=(N+F) / R$

Renovabilidade (\%R): indica a porcentagem de Emergia utilizada no sistema que advém de recursos renováveis. Os sistemas com alto valor percentual de renovabilidade são menos dependentes da economia e de recursos não renováveis. Portanto, este índice expressa a razão de emergia renovável usada em relação à emergia total consumida do sistema.

Procedimento de cálculo:

$\% R=R / Y .100 \%$.

Sustentabilidade (S): expressa a eficiência emergética do processo analisado em relação à sua carga ambiental. A sustentabilidade do sistema é 
diretamente proporcional à eficiência emergética e indiretamente proporcional à carga ambiental.

Procedimento de cálculo:

$$
S=E Y R / E L R
$$

Nesta AICV, a emergia segue as orientações e os requisitos para a seleção de categorias de impacto, os indicadores de categoria e os modelos de caracterização de acordo com ISO (2000a) e ABNT (2004a). A categoria de impactos para a aplicação da emergia como método de AICV é o consumo de energia solar equivalente.

O indicador de categoria para o consumo de energia solar equivalente é a energia solar equivalente incorporada (sej). O modelo de caracterização dessa categoria de impacto é dado pelo método da Emergia.

A classificação para o consumo de energia solar equivalente, modelado pela Emergia, tem base nos insumos do ciclo de vida. Estes são identificados, no resultado do ICV, como consumo de recursos e consumo de energia, assim como mão-de-obra utilizada, além dos equipamentos e edificações incorporados pelo método da Emergia.

A tabela 7 resume os componentes do mecanismo ambiental da AICV pela Emergia, de acordo com ISO (2000a) e ABNT (2004a).

Tabela 7- Componentes do mecanismo ambiental da AICV pela Emergia

\begin{tabular}{ll}
\hline Componentes do mecanismo ambiental & Aplicação na Emergia \\
\hline Categoria de impacto & Consumo de energia solar equivalente \\
Resultados do ICV & $\begin{array}{l}\text { Consumo de recursos renováveis e não renováveis, } \\
\text { consumo de energia e mão-de-obra }\end{array}$ \\
Modelo de caracterização & Emergia \\
Indicador de categoria & Energia solar equivalente incorporada \\
Fator de caracterização & Transformidade: quantidade de energia solar \\
& equivalente incorporada na formação dos insumos \\
& pela quantidade do produto (sej / kg produto) \\
Resultado do indicador & sej (energia solar equivalente) ou emj (emjoules) \\
Pontos finais da categoria & Energia solar, das marés e o calor interno da Terra \\
Relevância ambiental & Espacial: global \\
\hline
\end{tabular}


Para a valoração ambiental, a Emergia, por estar diretamente relacionada à produtividade e baseada em relações físico-biológico-sociais, que descrevem a relação de causa e efeito do consumo da energia solar incorporada nos insumos e serviços utilizados em processos produtivos, pode ser enquadrada como um método de valoração direta. Como em sua abordagem se incluem os aspectos ecológicos e os humanos, a valoração ocorre por meio do valor de uso indireto dos insumos, de acordo com seu valor ecossistêmico de formação.

\subsubsection{Limitações e diferenças dos métodos de AICV}

A grande diferença entre o EDIP, a Emergia e a Exergia é que o EDIP foi desenvolvido para a avaliação direta do potencial de impacto ambiental, de acordo com as propriedades das substâncias, enquanto os outros métodos são correlações relacionadas ao potencial energético de consumo e de perdas. Basicamente, a diferença centra-se nas categorias de impactos correspondentes e no procedimento de cálculo, segundo o mecanismo ambiental de cada modelo.

O modelo desenvolvido usando o EDIP baseia-se nas características da substância frente ao impacto ambiental específico, como aquecimento global, acidificação, toxicidade, entre outros. A Exergia é baseada em modelos termodinâmicos e pode ser aplicada para avaliar o impacto físico-químico direto. A Emergia é baseada na Termodinâmica, na Biologia, na Teoria Geral de Sistemas e na Ecossistêmica, para avaliar o consumo de energia solar equivalente dos materiais e dos serviços utilizados em processos produtivos.

Da mesma gênese do EDIP, outros dois métodos internacionalmente aceitos e utilizados, com os quais o EDIP pode ser comparado diretamente, são os holandeses Eco-indicator 99 e CML 2001 (Life Cycle Assessment - An operational guide to the ISO Standards 2001).

Dreyer et al. (2003) realizaram uma comparação entre esses três métodos com relação à AICV, a partir dos resultados do ICV do estudo de um selador de tinta à base de água, produzido por uma indústria dinamarquesa, 
usando como unidade funcional a decoração e a proteção de uma portapadrão de cozinha por 20 anos.

Os resultados do estudo mostram que o EDIP e o CML 2001 são semelhantes quanto aos seus escopos e estruturas, ambos se diferenciando do Eco-indicator 99.

As maiores diferenças entre o EDIP e o CML 2001 encontram-se nas categorias de impacto: toxicidade humana e ecotoxicidade. No CML 2001, os maiores contribuintes para a toxicidade humana são os metais, enquanto no EDIP são os solventes e óxidos de nitrogênio. Para ecotoxicidade aquática, os metais são os maiores contribuintes para ambos os métodos, contudo enquanto o elemento de maior potencial para o CML 2001 é o Vanádio, para o EDIP é o Estrôncio. Após a etapa de normatização, as diferenças se reduzem, embora ainda existam.

Comparando o EDIP com o Eco-indicator, Dreyer et al. (2003) indicam que o maior contribuinte para o potencial de impacto ambiental é o óxido de nitrogênio (NOx). Contudo, no Eco-indicator, o NOx apresenta potencial de impacto muito maior, contribuindo para a toxicidade humana, enquanto, no EDIP, o alto potencial do NOx ocorre para a acidificação e a eutrofização.

Portanto, dependendo do estudo de $\mathrm{ACV}$, o método utilizado para a AICV é muito importante e pode definir os resultados. Para o EDIP e o CML, a diferença se acentua quando se estudam os impactos dos químicos para a saúde humana e do ecossistema, ou seja, para as categorias de toxicidade humana e ecotoxicidade.

Com relação ao EDIP frente ao Eco-indicator, as divergências são maiores desde a estrutura até os resultados dos impactos, os quais podem ser até opostos. A recomendação de Dreyer et al (2003) concentra-se na necessidade de mais estudos sobre os potencias de toxicidade humana $\mathrm{e}$ ecotoxicidade das substâncias químicas.

Comparando-se a Emergia e a Exergia, a primeira diferença básica entre as duas avaliações está centrada na gênese e na finalidade para a qual elas foram desenvolvidas. A Emergia foi aprimorada por Odum, com o objetivo de entender e de quantificar os fluxos energéticos dos ecossistemas naturais. A 
Exergia, por sua vez, foi desenvolvida dentro da área da Engenharia Mecânica, a partir da Termodinâmica Clássica, com o objetivo de avaliar sistemas produtivos, principalmente energéticos, de modo a indicar os pontos de maiores perdas de trabalho mecânico e o cálculo de eficiências com relação à segunda lei da Termodinâmica.

A partir desse ponto, cada avaliação desenvolveu-se e continua em processo de aprimoramento, a fim de resolver os problemas estabelecidos, de acordo com seus escopos e finalidades.

Harendeen, em Brown e Harendeen (1996), cita que as avaliações energéticas como um todo: 1) não se orientam para a otimização; 2) podem avaliar os poluentes diretos e indiretos emitidos e 3) não quantificam o papel do ambiente na absorção e no processamento da poluição.

Relacionando essas citações com a Exergia, algumas discussões podem ser indicadas de acordo, respectivamente, com os pontos estabelecidos por Harendeen :

1) o fato de a Exergia quantificar as perdas de trabalho útil e as eficiências reais de processos faz com que esta avaliação possa ser utilizada e destinada, de modo a ajustar as variáveis de processo, a fim de reduzir as perdas, aumentar a eficiência e, com isso, otimizar o processo;

2) com relação à possibilidade de quantificação de poluentes diretos e indiretos, avaliações energéticas são factíveis, se considerarmos, por exemplo, poluentes indiretos como os ocasionados por processos anteriores ao analisado, como por exemplo, por meio de estudo de ACV. De outro modo, com relação à Exergia, apesar de esta análise quantificar os impactos diretos físicos e químicos, por meio do trabalho absorvido pelo meio, os danos indiretos, assim como os impactos biológicos, sociais, econômicos e culturais que um poluente pode causar não são quantificados pela avaliação exergética; 
3) a Exergia tem a capacidade, apesar de restrita à absorção físico-química direta, de quantificar o trabalho do ambiente na absorção e no processamento da poluição.

A Emergia, por sua vez, de acordo com Brown, em Brown e Harendeen (1996), representa a memória da energia solar utilizada na construção de um sistema. Como resultado, o autor considera que Emergia não é energia e não se comporta como tal. Isso faz com que alguns princípios da Emergia possam parecer violar as leis da Termodinâmica.

Um dos princípios emergéticos é o Maximum Emergy Principle, ou Princípio da Máxima Emergia, o qual indica que sistemas, quando em competição com outros, desenvolvem o maior trabalho útil ${ }^{22}$ com os recursos disponíveis, aumentando a produção e superando suas limitações, por meio da organização do sistema.

Além disso, as estratégias para a máxima Emergia ocorrem de duas formas: pela maximização da eficiência de produção e pela maximização da diversidade e da cooperação (diferente da energia ou Exergia, que visa somente à primeira estratégia).

Brown, em Brown e Harendeen (1996), indica que, considerando o sistema global, para os sistemas serem organizados de modo a maximizar potência, qualquer perda de energia precisa retornar como trabalho útil equivalente a, no mínimo, o que foi perdido.

Assim, a sugestão de Brown de que não há perda de energia, já que esta se transforma em algum tipo de trabalho útil, confronta a segunda lei da Termodinâmica, especificamente a Exergia, pela qual se sabe que há perdas que não são recuperáveis pelo sistema - as irreversibilidades. Todavia, no decorrer do artigo, Brown sugere que pode haver perdas, mas que o componente do sistema que não gerou a maximização de potência será rejeitado.

O princípio da máxima Emergia sugere, ainda, que o valor de um sistema se baseia no fornecedor de energia para o sistema, e não no receptor.

\footnotetext{
${ }^{22}$ Trabalho útil, neste contexto, significa próprio fortalecimento (reforço) e definido como o uso dos fluxos emergéticos de entrada para ações de retroalimentação que assegurem, se possível, o aumento da entrada de Emergia (Brown e Harendeen, 1996).
} 
Com isso, o valor é derivado de quanto de energia entra no sistema, e não de quanto se está disposto a pagar por ele, com base no mercado. Isso é uma grande contribuição à Valoração Ambiental, a qual se baseia, muitas vezes, em métodos contingentes, indiretos, na disposição de se pagar por um determinado serviço ambiental, não computando os valores de formação do bem natural.

No cálculo emergético, a primeira regra citada por Brown, em Brown e Harendeen (1996), determina que todas as entradas de Emergias são somadas ao produto, sem se contabilizarem as perdas. Se a base de cálculo da transformidade dos insumos tiver sido a Exergia, esse procedimento procede, pois as perdas já foram computadas; entretanto se foram calculadas pela primeira lei, o procedimento fere a segunda lei da Termodinâmica. Ainda, pelo conceito da Emergia, não são consideradas as perdas de Emergias durante o processo, pois, para a formação do produto, é necessária toda a Emergia de entrada.

A segunda regra de cálculo emergético refere-se a processos com mais de um produto, no qual o valor emergético de cada produto é o somatório das entradas de Emergia. Desse modo, há uma quantidade maior de Emergia que sai do que de Emergia que entra, não sendo, assim, conservativo.

Embora ferindo a Lei de Conservação da Energia (primeira lei da Termodinâmica), Brown, em Brown e Harendeen (1996), explica que a análise emergética considera que para um sistema existir e se manter, todos os elementos são essenciais e devem ser integralmente contabilizados para a geração de cada produto.

Para análises energéticas, Harendeen, em Brown e Harendeen (1996), sugere que os fluxos de processo de cada produto devem ser separados e as frações, contabilizadas para cada produto.

Bakshi (2002) resume as diferenças entre Energia, Exergia e Emergia, as quais são apresentadas na tabela 8. 
Tabela 8: Propriedades da Energia, Exergia e Emergia

\begin{tabular}{|c|c|}
\hline Energia & Emergia \\
\hline 1. Satisfaz a lei da conservação & 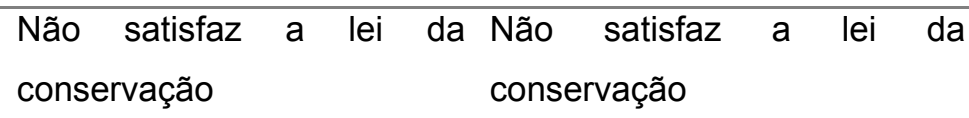 \\
\hline $\begin{array}{l}\text { 2. Depende do estado da } \\
\text { matéria sob consideração }\end{array}$ & $\begin{array}{l}\text { Depende do estado da Depende do estado da } \\
\text { matéria sob consideração e matéria sob consideração } \\
\text { do estado de referência }\end{array}$ \\
\hline $\begin{array}{l}\text { 3. Independe do caminho para } \\
\text { atingir determinado estado }\end{array}$ & $\begin{array}{l}\text { Independe do caminho para Depende do caminho para } \\
\text { atingir determinado estado atingir determinado estado }\end{array}$ \\
\hline
\end{tabular}

Fonte: BAKSHI (2002).

Bakshi (2002) cita, ainda, outras diferenças entre Emergia e Exergia, quanto à desconsideração da Exergia no que se refere ao processo de formação ecológica dos recursos e dos serviços ambientais, considerados pela Emergia.

Com relação à inclusão do trabalho humano e natural, a avaliação emergética os inclui como mão-de-obra e recursos naturais, respectivamente, enquanto, apesar de as avaliações energéticas clássicas, como a Exergia, poderem contabilizá-los, dificilmente se encontram análises com tais considerações.

Em análises Termodinâmicas de sistemas, Brown, em Brown e Harendeen (1996), indica que a Emergia assume maior importância nos componentes das posições superiores da hierarquia do sistema, enquanto as avaliações energéticas e exergéticas assumem valores de maiores importâncias para os componentes iniciais.

O mesmo se verifica em Minkel (2002), quando cita, na conclusão de seu artigo na revista New Scientist, que os raios solares são os componentes de maior Exergia no ecossistema e que, no decorrer da cadeia trófica, cada nível sofrerá uma perda de Exergia pelas irreversibilidades que ocorrem de um nível para o outro, diminuindo-se a quantidade de trabalho útil possível de se obter no produto final. 
A Emergia, por outro lado, avalia a qualidade da energia incorporada para a formação e a estruturação de produtos ou de organismos. Desse modo, os raios solares são os de menor transformidade (Emergia/energia), aumentando de acordo com a cadeia produtiva ou trófica, pois os organismos mais complexos são os de maiores transformidades.

Embora, inicialmente, as duas análises possam parecer conflitantes, elas são coerentes com seus pressupostos conceituais e teóricos, mostrandose complementares, visto que a Exergia avalia os fluxos com base no trabalho mecânico a ser realizado para se atingir o estado físico (temperatura e pressão) e químico padrão de equilíbrio do ambiente, enquanto a Emergia avalia a formação biogeoquímica dos elementos. Percebe-se, desse modo, que as escalas temporais de análise das duas metodologias diferem, e também se complementam.

Esta consideração é ratificada em Bakshi (2002), que explica que a Emergia contabiliza os insumos do ambiente para os produtos e serviços, enquanto a Exergia é a medida do potencial dos produtos e dos serviços que podem ser entregues ao ambiente.

As avaliações de impactos ambientais completas devem analisar os impactos ambientais diretos e indiretos, em termos físicos, químicos, biológicos e antrópicos - sócio-econômico-culturais. Em termos de quantificação e de valoração de impactos ambientais, a exergia é uma poderosa ferramenta para os impactos ambientais diretos físicos e químicos de emissões. É indicada como um método de valoração direta do impacto das emissões, pelos seus valores de uso direto.

A Emergia, por outro lado, apresenta a capacidade de avaliar o modo de aquisição dos recursos no sistema homem-ambiente como um todo, valorando os insumos utilizados, em termos de energia solar equivalente, mas não quantifica os impactos ambientais. É indicada como um método de valoração direta dos recursos utilizados, pelo seus valores de usos indiretos ecossistêmicos.

Desse modo, no que se refere à avaliação e à valoração ambiental, indica-se a utilização da emergia e da exergia de forma complementar. 
A valoração ambiental é realizada como parte da avaliação de impacto do ciclo de vida, abordando-se a teoria econômica com base nas relações ambientais e termodinâmicas.

Contudo tais valores são avaliados, neste trabalho, a fim de subsidiar o entendimento do funcionamento do meio e sua interação com o sistema produtivo, e não para serem utilizados como base de monetarização no mercado de capitais, pois as questões ponderadas no mercado são incompatíveis com as questões ambientais. Uma das diferenças é a escala temporal: o mercado valoriza no curto período, enquanto a área ambiental pondera com vistas às futuras gerações. Outras diferenças ocorrem pelo princípio da Economia relacionado à escassez relativa, indicando que, quanto mais escasso o recurso, maior é o valor. Este princípio está em oposição ao princípio ambiental de preservação e de conservação. Além disso, a gênese do mercado é a regulação das relações de troca de mercadorias entre as pessoas, e o meio não é uma mercadoria que possa ser objeto de troca.

Portanto, é utilizado a teoria econômica, com base nos conceitos ambientais e termodinâmicos, neste estudo teórico de valoração ambiental, não se indicando a prática na Economia corrente, com base nestes resultados.

\subsubsection{Elementos opcionais da AICV}

Os elementos opcionais para a AICV podem ser definidos, segundo ISO (2000a), Udo de Haes (2002) e ABNT (2004b), como:

- Normatização: cálculo da magnitude dos resultados do indicador de categoria com relação a uma informação de referência;

- Agrupamento: correlação das categorias de impactos em um ou mais conjuntos que apresentem semelhanças, ou designação de impactos de alta, média ou baixa prioridade;

- Ponderação: processo de conversão dos resultados dos indicadores de diferentes categorias de impacto por meio do uso de fatores numéricos baseados em escolhas de valores. 
Segundo Wenzel et al. (1997), para estudos de ACV, as especificidades locais do meio, assim como os efeitos sociais, culturais, econômicos e políticos das atividades do ciclo de vida, não são considerados nas etapas prioritárias da AICV, podendo ser considerados na ponderação. As partes opcionais não são realizadas neste estudo de $\mathrm{ACV}$ do álcool combustível.

\subsection{Interpretação do ciclo de vida}

De acordo com ABNT (2001) e ISO (1997), a interpretação é a fase da ACV na qual os resultados do ICV e da AICV são combinados com o objetivo e o escopo, de modo a se obter em conclusões e recomendações. Essa fase é apresentada neste trabalho no capítulo de conclusões.

As constatações na interpretação podem servir de subsídios para os tomadores de decisão e devem ser consistentes com o objetivo e o escopo do estudo. Segundo ABNT (2001) e ISO (1997), as decisões e as ações subseqüentes podem incorporar implicações ambientais, desempenho técnico, aspectos econômicos e sociais. 


\section{Capítulo 4. Resultados}

\section{Apresentação da Avaliação do Ciclo de Vida do Álcool Etílico Hidratado Combustível}

\subsection{Definição do objetivo e do escopo}

Este estudo de ACV tem o objetivo de avaliar o ciclo de vida do álcool etílico hidratado combustível frente aos potenciais de impactos ambientais de cada atividade, valorar os insumos e as emissões do ciclo e indicar oportunidades de melhorias ambientais.

A seguir, arrolam-se os elementos que compõem o escopo da ACV do álcool etílico hidratado combustível:

\section{- Função do sistema}

O objeto deste estudo de ACV é o álcool etílico hidratado combustível, produzido a partir da cana-de-açúcar em usina convencional na região de Ribeirão Preto, SP. A função do álcool hidratado é ser utilizado como combustível em veículos automotores para transporte.

- Unidade funcional

A unidade funcional é $10.000 \mathrm{~km}$ percorridos com álcool etílico hidratado combustível por um carro de 1.600 cc.

\section{- Fluxo de referência}

O fluxo de referência relacionado à unidade funcional e utilizado para obtenção dos dados do ICV é $1.000 \mathrm{~kg}$ ou 1t de álcool hidratado. 


\section{- Sistema de produto}

As unidades de processo que compõem o sistema de produto do álcool etílico hidratado combustível são as seguintes atividades:

Atividade 1: Preparo do solo

Atividade 2: Plantio da cana-de-açúcar

Atividade 3: Tratos culturais

Atividade 4: Colheita da cana-de-açúcar

Atividade 5: Processo industrial do álcool etílico hidratado combustível: o qual é composto pelas atividades de moagem da cana, de tratamento do caldo, de fermentação e de destilação. Os produtos da moagem da cana são o caldo, a torta de filtro e o bagaço. $O$ caldo é usado para produzir álcool; a torta de filtro é usada como fertilizante, junto com a vinhaça, na área agrícola e o bagaço é utilizado para a geração de vapor e de energia elétrica a usar no processo industrial do álcool. Os produtos finais da destilação são o álcool e a vinhaça, a qual é usada como fertilizante na fertirrigação da área de cultivo da cana-deaçúcar.

Atividade 6: Geração de vapor e de energia elétrica

Atividade 7: Fertirrigação

Atividade 8: Distribuição do álcool etílico hidratado combustível

Atividade 9: Utilização do álcool etílico hidratado combustível

O sistema de produto, mostrado na figura 22 , inclui, além das nove unidades de processo indicadas, as etapas de extração de calcário $\left(\mathrm{CaCO}_{3}\right)$ e a cadeia de produção do fertilizante fosfatado $\left(\mathrm{P}_{2} \mathrm{O}_{5}\right)$.

A armazenagem do álcool estava sendo considerada no início, contudo no decorrer do trabalho foi verificado que não apresentava nenhum aspecto ambiental considerável. Desta forma, não foi incluída nos resultados da ACV do álcool etílico hidratado combustível. 


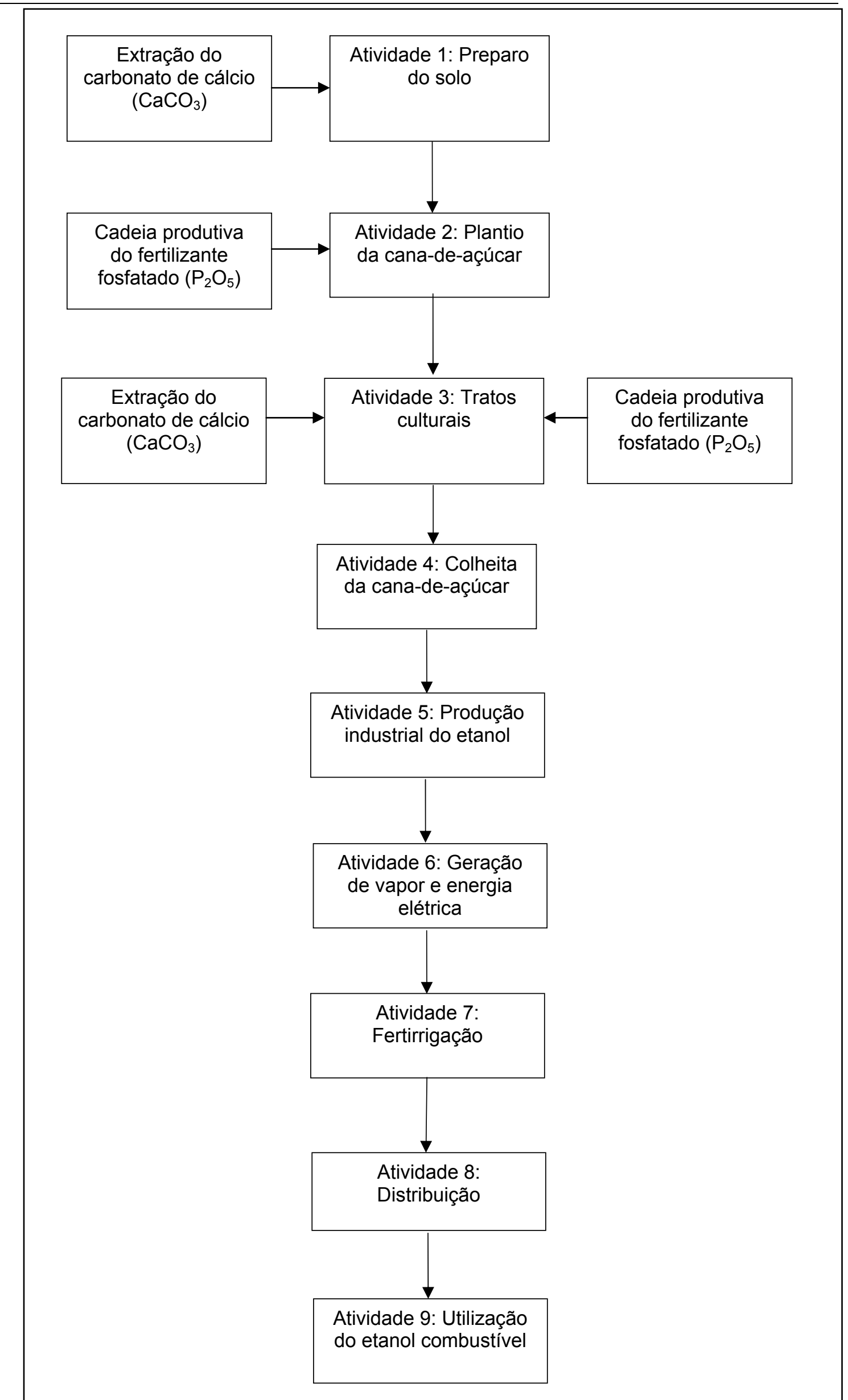

Figura 22 - Sistema de produto do álcool etílico hidratado combustível 


\section{- $\quad$ Fronteiras do sistema de produto}

A fronteira do sistema foi definida pelo critério de corte dos insumos em quantidades menores que $0,34 \%$ do total dos insumos diretamente utilizados, ou seja, $50 \mathrm{~kg}$ para cada unidade de processo, e pelo potencial de impacto ambiental da cadeia produtiva do insumo utilizado.

Desse modo, além das unidades de processos, foram avaliadas as etapas de extração de calcário (CaCO3), pois a quantidade utilizada está acima do critério de corte e a cadeia de produção do fertilizante fosfatado $-\mathrm{P}_{2} \mathrm{O}_{5}$, pois ela apresenta alto potencial de impacto ambiental e é muito utilizada no Brasil, de acordo com Kulay (2000).

O uso do diesel, devido à relevância ambiental, também foi avaliado, assim como todo insumo e emissão das unidades de processo.

- Procedimento de alocação

Seguindo o método EDIP, indicado por Wenzel et al. (1997), há dois critérios principais para alocar os dados, quando o processo apresenta mais de um produto, os quais são:

- técnico:

- econômico.

Neste estudo, foi utilizado o critério técnico pela massa nas atividades que são similares para o álcool e a fabricação do açúcar, que são as etapas de moagem e de preparação do caldo na atividade 5 (produção industrial do álcool etílico hidratado combustível).

$\mathrm{Na}$ atividade 6 (geração de vapor e de energia elétrica) também foi estabelecido o critério técnico pela massa, a partir da alocação, para o ciclo do álcool, da porcentagem em massa relativa à quantidade de bagaço utilizado com fins de geração de vapor e de energia elétrica no processo industrial do álcool combustível, excluindo os aspectos e impactos da quantidade de bagaço excedente utilizado para outros fins.

O transporte nas atividades internas de produção agrícola e industrial é avaliado em cada atividade da qual o produto provém, sendo descritas as 
considerações específicas para cada atividade do ciclo de vida na análise de inventário.

Nas demais atividades, não houve a necessidade de alocação, seguindo a indicação de Wenzel et al. (1997) de realizá-la somente quando for imprescindível.

- Tipos de impacto, método de avaliação de impacto e interpretação subseqüente a ser usada

Os métodos utilizados neste estudo avaliam o comprometimento da atividade nos sistemas ambientais, na saúde humana e no esgotamento de recursos, valorando-os em termos energéticos.

Este estudo inclui além da avaliação de impacto pelo método EDIP, segundo Wenzel et al. (1997), a avaliação e a valoração ambiental dos insumos e dos serviços utilizados no ciclo de vida pela Emergia e das principais emissões atmosféricas pela Exergia.

As categorias de impactos utilizadas pelo método EDIP são o consumo de recursos renováveis, de não-renováveis e de energia, assim como os seguintes potenciais de impactos ambientais: aquecimento global, formação fotoquímica de ozônio troposférico, acidificação, eutrofização, ecotoxicidade e toxicidade humana.

A interpretação desses resultados pode indicar as atividades que mais comprometem cada categoria, subsidiando mudanças que visem à redução dos potenciais de impactos.

A categoria avaliada pela Exergia é o impacto físico-químico direto das emissões no compartimento atmosférico e a categoria avaliada pela Emergia é o consumo de energia solar equivalente pelos insumos e pelos serviços utilizados.

A utilização dos métodos da Exergia e da Emergia para a valoração ambiental completa a avaliação de impacto, de acordo com os objetivos do estudo de ACV do álcool etílico hidratado combustível.

A interpretação dos resultados da Exergia indica as perdas de trabalho mecânico para a atmosfera. A interpretação desses resultados, tendo como 
referência a atmosfera, indica o trabalho que esta precisou absorver, equilibrando a emissão para o estado-padrão físico-químico. Portanto, o impacto da emissão valorado pela Exergia é o impacto físico-químico direto causado na atmosfera.

A interpretação dos resultados da Emergia indica a eficiência ecossistêmica das atividades do ciclo de vida do etanol hidratado combustível em utilizar os recursos advindos da natureza e do sistema econômico.

\section{- Requisitos dos dados}

Os dados foram coletados de fontes primárias - amostra direta do processo analisado; secundárias - revisão bibliográfica e entrevistas e por algumas considerações realizadas por especialistas com alto grau de experiência e conhecimento comprovado dos setores avaliados.

Muitos dos dados foram obtidos diretamente dos processos em usina convencional da região de Ribeirão Preto, SP, e outros, da literatura ou de especialistas, realizando-se a definição específica da fonte dos dados para cada dado nos resultados da análise de inventário.

Os dados das nove atividades principais do ciclo de vida do etanol, que correspondem às unidades de processo, foram adquiridos diretamente no processo, sendo os demais completados pela bibliografia e por consulta a especialistas.

Os dados da extração do carbonato de cálcio $\left(\mathrm{CaCO}_{3}\right)$ e do consumo de diesel nos tratores, caminhões e ônibus foram obtidos a partir do banco de dados do EDIP, com o uso do software Simapro. Os dados do consumo de diesel, pelo banco de dados do EDIP, são avaliados com base na distância percorrida pelo veículo a diesel e pela carga transportada. Os dados de peso da carga e de distância percorrida são de fonte primária. Os dados da cadeia do fertilizante fosfatado foram obtidos de Kulay (2000).

A origem dos dados primários é datada de até cinco anos, com um ano de amostragem e geograficamente compatível com a área de estudo. 
A base principal da avaliação do sistema de produto é o fluxo de massa das entradas e das saídas; contudo o consumo de energia elétrica também é contabilizado.

\section{Suposições/ Considerações}

O estudo baseia-se nas práticas convencionais utilizadas no ciclo de vida do álcool etílico hidratado combustível em usina-padrão na região de Ribeirão Preto, SP.

Considera-se que a cultura agrícola da cana-de-açúcar já se apresenta instalada, sendo a principal matéria-prima para a produção industrial.

O transporte interno é avaliado pelo consumo de diesel de cada atividade de onde o transporte se origina. Assim como o transporte interno, as demais atividades também são avaliadas a partir das suas práticas convencionais.

O nível tecnológico das atividades do ciclo de vida do álcool é o tradicional dos anos de 2001 a 2004, para a produção agrícola e industrial da região de Ribeirão Preto, SP.

Embora possa haver alterações das atividades, devido aos aspectos jurídicos da queimada e de avanços tecnológicos para a mecanização, as informações gerais deste estudo apresentam perspectiva de potencial para serem utilizadas como o usual para aplicações industriais: 10 anos.

O nível tecnológico do motor do veículo relacionado a este estudo, na fase de utilização do álcool combustível, caracteriza-se como de um veículo de 1.600 cc. O consumo médio do álcool combustível hidratado é considerado, segundo a Anfavea (2004), de $8 \mathrm{~km} / \mathrm{l}$ em veículos automotores brasileiros de 1.600 cc. para transporte de pessoas.

A rotação de culturas não foi considerada, pois os dados respectivos à nova cultura (amendoim, soja, etc) iriam ser alocados para esta, visto que os produtos dessas culturas são vendidos comercialmente e pela alocação econômica que seria realizada, não influenciaria a avaliação do ciclo de vida do álcool. 
Para a coleta e o tratamento dos dados na análise de inventário foi considerado, como base de obtenção dos dados e de cálculo, o fluxo de referência para a produção de $1000 \mathrm{~kg}$ de álcool (correspondente a 1250 litros de álcool). Portanto, o tratamento dos dados de entrada e de saída das unidades de processo estão quantificados para uma tonelada de álcool, mas o resultado final da análise de inventário e da avaliação de impacto é dada por quilômetro rodado com o álcool. O fluxo de referência é em massa, para não sofrer variações, dependendo da temperatura e da pressão.

Para o fluxo de referência de $1.000 \mathrm{~kg}$, o tempo de vida do produto é de dois anos, sendo um ano para o cultivo da cana-de-açúcar, o processo industrial e o transporte e um ano de uso do produto.

Considera-se a produtividade média ponderada de cana-de-açúcar de 65 toneladas por hectare de área plantada, incluindo a área de renovação do canavial; 79,5 litros de álcool por tonelada de cana e massa específica do álcool, a $25^{\circ} \mathrm{C}$, como $0,8 \mathrm{~kg} / \mathrm{l}$, segundo o Ministério de Ciência e Tecnologia (2003).

Para o tratamento dos dados, considera-se, portanto, que são necessárias $15.723,27 \mathrm{~kg}$ de cana para a produção de $1.000 \mathrm{~kg}$ de álcool, o que corresponde a, aproximadamente, 0,24ha.

Como os dados foram calculados pela massa, a transformação dos dados dos produtos utilizados em litros é realizada por meio da concentração média encontrada na pesquisa bibliográfica da composição e da massa específica dos mesmos.

Os dados do inventário e a avaliação dos impactos do consumo de diesel dos tratores, caminhões, equipamentos agrícolas e ônibus são considerados, porque são utilizados em muitas atividades e, com isso, seus impactos são importantes para todo o ciclo. Foi considerada a massa específica média do óleo diesel igual a $0,85 \mathrm{~kg} / \mathrm{l}$, segundo o Ministério de Ciência e Tecnologia (2003).

Para a categoria de impacto potencial de aquecimento global do EDIP, considerou-se o efeito do potencial de impacto para 100 anos. 
Com relação à formação fotoquímica de ozônio troposférico, como grande parte das atividades do ciclo de vida do álcool ocorrem em área rural, consideram-se os fatores de equivalência de Wenzel et al. (1997), referentes a áreas com baixa concentração de NOx, ou seja, abaixo de 10ppbv ou 0,02 $\mathrm{mg} / \mathrm{m}^{3}$.

Para a avaliação da ecotoxicidade pelo EDIP, a aplicação de pesticida no solo é considerada como impacto para o compartimento do solo, visto como um recurso biológico e não do sistema de produção. O resultado disso é que esses valores são uma estimativa do máximo impacto causado na primeira aplicação do pesticida no solo in natura. É considerado que todo pesticida aplicado em uma determinada área nela permaneça.

As maiores quantidades de emissões atmosféricas do ciclo de vida do álcool combustível são avaliadas pelo método EDIP e pela Exergia. Para tais avaliações, a base de dados é o resultado da análise de inventário com uma ressalva para o $\mathrm{CO}_{2}$.

Para a avaliação pelo método EDIP, $\mathrm{O} \mathrm{CO}_{2}$ é um gás de efeito estufa. Este efeito é um impacto considerado global, sendo o fator do potencial de impacto utilizado para o período de 100 anos. Considera-se que a quantidade de $\mathrm{CO}_{2}$ emitido pelos processos que envolvem subprodutos da cana seja absorvida pela fotossíntese da planta durante seu crescimento. Portanto, para a avaliação do potencial de efeito estufa, $\mathrm{O}_{\mathrm{CO}_{2}}$ emitido pela queimada da cana-de-açúcar (na atividade 4), pela fermentação do álcool (na atividade 5), pela queima do bagaço nas caldeiras (na atividade 6) e na utilização do álcool (atividade 9) não foi considerado.

Contudo, para a avaliação e valoração exergética, a qual mede o potencial de impacto físico-químico direto da emissão, independente se ela é absorvida, foi considerada a quantidade total de $\mathrm{CO}_{2}$ emitido.

As etapas da avaliação e valoração exergética das maiores quantidades de emissões atmosféricas são realizadas com base no fluxo de referência (1 t álcool), sendo o resultado final apresentado, também, pela unidade funcional (1 km álcool percorrido). 
As considerações para a alocação dos resultados da avaliação e da valoração emergética são:

- Emergia para $1 \mathrm{t}$ de álcool para todas as atividades (com exceção da atividade 1 e 2) é igual ao resultado da Emergia (sej/ha.ano) vezes 0,24 ha;

- Emergia para 1 t de álcool para as atividades 1 e 2 é igual ao resultado da Emergia (sej/ha.ano) vezes 0,048 ha;

- Emergia para $1 \mathrm{~km}$ rodado com álcool para todas as atividades é igual ao resultado da Emergia para $1 \mathrm{t}$ álcool dividido por $10.000 \mathrm{~km}$.

Para todos os insumos e os serviços, os resultados da avaliação e da valoração emergética são apresentados na unidade tradicional do método (sej/ha.ano), para o fluxo de referência (1 $\mathrm{t}$ álcool) e para a unidade funcional (1 $\mathrm{km}$ rodado com álcool).

As considerações específicas, realizadas para cada atividade do ciclo de vida do álcool etílico hidratado combustível, estão descritas a seguir.

- Atividade 1: Preparo do solo

Considerando-se a cultura já instalada e a realização de cinco cortes da cana-de-açúcar para realizar a renovação do canavial, as atividades de preparo do solo são executadas, anualmente, em $20 \%$ da área total agrícola com canade-açúcar, ou seja, para o fluxo de referência, de acordo com as considerações iniciais, $20 \%$ de 0,24 ha, ou seja, 0,048ha.

De acordo com dados primários, para a renovação do canavial, é utilizado o processo mecânico em $35,8 \%$ da área e o processo químico em $64,2 \%$. Desse modo, para o processo mecânico, a área correspondente para o fluxo de referência é $0,0172 \mathrm{ha}\left(172 \mathrm{~m}^{2}\right)$ e para o processo químico, 0,0308ha $\left(308 \mathrm{~m}^{2}\right)$.

A distância total percorrida pelos equipamentos agrícolas da atividade 1 foi estimada pela média ponderada do consumo dos equipamentos agrícolas e pela velocidade média ponderada da potência dos equipamentos para as operações agrícolas dessa atividade. 
A partir de dados primários, o consumo médio ponderado dos equipamentos agrícolas da atividade 1 é de 22,57 I/h e, segundo Ripoli (2004), a velocidade média de um trator de $100 \mathrm{cv}$ (a média ponderada das potências), para as operações de campo da atividade 1 , é de $5,5 \mathrm{~km} / \mathrm{h}$. Com o dado primário de consumo de 4,69 l de diesel no total das operações agrícolas da atividade 1, a distância total percorrida nas operações pelos equipamentos agrícolas é de 1.142,82 $\mathrm{m}$.

Pelos dados primários brutos, os implementos agrícolas são transportados por caminhões, para as operações mecânicas de 7.000 ha, consumindo 57,7 litros de diesel. Com relação ao fluxo de referência, foi calculado o consumo relativo para a área de 0,048ha, chegando-se a 0,0004 litros. Para o consumo médio de $4 \mathrm{~km} / \mathrm{l}$ pelos caminhões utilizados, a distância relativa percorrida é de $0,0016 \mathrm{~km}$.

Pelos dados primários, a massa dos implementos agrícolas transportados para as operações agrícolas é 3,8 toneladas. Portanto, o produto distância percorrida vezes massa transportada, para a avaliação dos aspectos relativos ao consumo de diesel a partir do banco de dados do EDIP, é 0,0016 $\mathrm{km}$ vezes $3,8 \mathrm{t}$, igual a $0,006 \mathrm{~km} . \mathrm{t}$.

- Atividade 2: Plantio da cana-de-açúcar

A atividade de plantio do canavial, sendo uma extensão do preparo do solo, é, também, realizada em $20 \%$ da área agrícola com cana-de-açúcar, ou seja, a área considerada para o fluxo de referência de uma tonelada de álcool é de 0,048ha.

Os equipamentos utilizados para o plantio manual são os caminhões para transportar a cana a ser plantada, os tratores com sulcadores e aplicadores de agrotóxicos, além dos ônibus para transportar os trabalhadores.

Pelos dados primários, para essa área de 0,048ha, o consumo de combustível dos tratores é de 1,68 litro de diesel, sendo o consumo médio de $17 \mathrm{l} / \mathrm{h}$. A velocidade média para tal operação pode ser estimada, segundo Ripoli (2004), como de 5,5 km/h. Desse modo, a distância percorrida pelos tratores, na atividade 2, para a produção de 1 tonelada de álcool, é de 543,53m. 
Para a realização do plantio manual, a cana é transportada em caminhões, os quais, a partir dos dados primários, apresentam consumo médio de 2,07 litros para a área de 0,048ha. Em média, o caminhão percorre $4 \mathrm{~km}$ com um litro; portanto a distância percorrida pelos caminhões, relativa ao plantio de cana-de-açúcar, para a produção de 1 tonelada de álcool, é de 8,28 $\mathrm{km}$.

Pelos dados primários, são utilizados $14.000 \mathrm{~kg}$ de cana para o plantio por hectare. Para a área de plantio, a qual corresponde a 0,048ha, essa quantia é de $672 \mathrm{~kg}$. Como, ao final do plantio, a carga transportada para a atividade é desprezível, desconsiderando-se a massa da carroceria, considerou-se a metade da massa de cana necessária para o plantio, como a massa transportada durante todo o percurso do caminhão, ou seja, 336 kg.

Portanto o fator distância multiplicada pela massa transportada para o plantio, o qual se utiliza para o cálculo dos aspectos referentes ao consumo de diesel dos veículos, a partir do banco de dados do EDIP, é 8,28 km vezes $0,336 \mathrm{t}$, igual a $2,78 \mathrm{~km} . \mathrm{t}$.

Na atividade de plantio há, também, a aplicação de agrotóxicos, os quais estão contabilizados a partir de dados primários, considerando-se o total das possíveis combinações médias utilizadas.

A distância do ônibus, para transportar os trabalhadores, foi calculada a partir dos dados primários de consumo, 0,06 litro para o fluxo de referência. Como o consumo médio é $4 \mathrm{~km} / \mathrm{l}$, a distância relativa percorrida pelo ônibus é de $0,24 \mathrm{~km}$.

A quantidade de fertilizantes utilizados tem como base os dados primários e os de Macedo et al. (2004). A taxa de emissão atmosférica de óxido nitroso $\left(\mathrm{N}_{2} \mathrm{O}\right)$ de $1,5 \%$ do fertilizante nitrogenado tem base em Macedo et al. (2004).

- Atividade 3: Tratos culturais

Os insumos e os adubos consumidos nesta atividade foram obtidos de dados primários e de Macedo et al. (2004). 
A principal atividade dos tratos culturais é a aplicação de agrotóxicos. Como existem muitas formulações para os agroquímicos utilizados, foi usada a média dos mais tradicionais e usuais.

As quantidades dos agrotóxicos obtidas pelos dados primários em l/ha, foram transformadas para g/ha, por meio das concentrações médias, segundo a Agencia Nacional de Vigilância Sanitária (2003), indicadas na tabela 9.

Tabela 9 - Concentração média por agrotóxico utilizado na cana-de-açúcar

\begin{tabular}{cc}
\hline Produto & Concentração $(\mathrm{g} / \mathrm{l})$ \\
\hline Gesapax (Ametrina) & 500 \\
Gamit (Clomozone) & 500 \\
2,4 D & 767 \\
Sencor (Metribuzin) & 480 \\
Provence & 750 \\
Roundup (Glifosato) & 480 \\
Combini (Tebuthiuron) & 500 \\
MSMA & 720
\end{tabular}

Fonte: Agencia Nacional de Vigilância Sanitária (2003).

As quantidades dos agrotóxicos Clorpirifos (Formicida), Fenitrotion e Hexazione foram obtidas em kg/ha, segundo Copersucar (1989) e Victoria (1993).

Os dados da cadeia produtiva do fertilizante fosfatado $\left(\mathrm{P}_{2} \mathrm{O}_{5}\right)$ foram obtidos em Kulay (2000).

O caminhão para o transporte dos insumos e agrotóxicos a aplicar apresenta, segundo dados primários, consumo de 1,81 litro, referente a 0,24 ha, e a massa de produtos transportados, de $224,28 \mathrm{~kg}$. Como o consumo médio do caminhão é de $4 \mathrm{~km} / \mathrm{l}$, este percorre $7,24 \mathrm{~km}$. Portanto, o produto distância multiplicada pela massa transportada, para o cálculo dos aspectos do consumo de diesel do caminhão, a partir do banco de dados do EDIP, é 7,24 $\mathrm{km}$ vezes $0,224 \mathrm{t}$, igual a 1,62 km.t. 
Pelos dados primários, o consumo do trator para a aplicação dos agrotóxicos e dos insumos, para a área correspondente a 1 tonelada de álcool, é de 0,88 litro. Como o trator utilizado, de $75 \mathrm{cv}$, apresenta consumo médio de $16 \mathrm{I} / \mathrm{h}$ a uma velocidade de $5,5 \mathrm{~km} / \mathrm{h}$, a distância percorrida, para as operações relativas aos tratos culturais, é de $0,3025 \mathrm{~km}$ ou $302,5 \mathrm{~m}$.

A taxa de liberação de $\mathrm{N}_{2} \mathrm{O}$ de $1,5 \%$ do fertilizante nitrogenado tem base em Macedo et al. (2004).

- Atividade 4: Colheita da cana-de-açúcar

A colheita de cana-de-açúcar pode ser feita a partir de cana queimada ou da cana crua. A consideração para este estudo segue os dados de Macedo et al. (2004) sobre o modo de colheita no Estado de São Paulo, os quais se assemelham aos dados primários:

- $63,8 \%$ manual;

- 36,2\% mecânica;

- $75 \%$ queimada e

- $25 \%$ crua.

Para a colheita manual, há ônibus e "vans" que consomem 4,57 litros de diesel para transportar os trabalhadores. Com o consumo de $4 \mathrm{~km} / \mathrm{l}$, é percorrida uma distância, relativa ao fluxo de referência de $1 \mathrm{t}$ de álcool, de $18,30 \mathrm{~km}$.

Para todos tipos de colheita, é necessário transportar a cana-de-açúcar da área de colheita para a indústria por meio de caminhões. Pelos dados primários, esse transporte é feito 30\% por treminhões (cana inteira) e $70 \%$ por "rodoanéis" (cana cortada), com consumo, respectivamente, de 1,4 litro e de 1,22 litro por tonelada de cana colhida. Portanto, para esta proporção e referente a 15,72 toneladas de cana, o consumo é de 20,03 litros. Com o consumo médio de $4 \mathrm{~km} / \mathrm{l}$, a distância percorrida para o transporte da cana colhida pelos caminhões, com relação ao fluxo de referência, é de 80,12 km.

A massa transportada de cana é a metade da colhida para a produção de uma tonelada de álcool, pois o caminhão percorre metade do percurso vazio 
e metade com a carga de 15,72 toneladas. Portanto, a massa média transportada é de 7,86 t.

O produto distância percorrida multiplicada pela massa média transportada, para o cálculo dos aspectos do consumo de diesel dos veículos, a partir do banco de dados do EDIP, é $80,12 \mathrm{~km}$ vezes $7,86 \mathrm{t}$, igual a 629,7 km.t.

Para as operações com as máquinas agrícolas, o consumo de combustível, de acordo com Macedo et al. (2004), é 40,41 litros por hora, para a colhedora, e 7,1 litros por hora, para a carregadora. Os dados primários apresentam, como consumo médio para os tratores e a empilhadeira, $15 \mathrm{l} / \mathrm{h}$ e a velocidade média para todas as operações, de $4,5 \mathrm{~km} / \mathrm{h}$.

A colhedora, pelos dados primários, consome 4,84 litros em relação ao fluxo de referência e, portanto, percorre $0,54 \mathrm{~km}$. A carregadora, como apresenta consumo, pelos dados primários, de 2,61 litros, percorre 1,65 km. Os tratores e a empilhadeira apresentam consumo total, de acordo com os dados primários, de 4,83 litros, percorrendo, portanto, 1,45 km. Desse modo, as máquinas agrícolas percorrem um total de $3,64 \mathrm{~km}$ na atividade de colheita, para a produção de $1 \mathrm{t}$ de álcool.

A quantidade de $\mathrm{CO}_{2}$ emitido pela queimada é indicada como emissão atmosférica, apesar da consideração de essa quantidade ser absorvida no crescimento da cana, a fim de se verificar a grande quantidade de gás carbônico que se emite em um curto período de tempo, durante o qual a queimada ocorre.

- Atividade 5: Produção industrial do álcool etílico hidratado combustível

A produção industrial de álcool foi considerada pelos processos tradicionais de produção do álcool, independente da fabricação do açúcar, realizando-se a fermentação do caldo após tratamento e a destilação.

As considerações pontuais adotadas e o tratamento dos dados para os fluxos de entrada do processo industrial estão indicados a seguir:

- Água de lavagem da cana: 
De acordo com Fiesp (2001), há o consumo de $8 \mathrm{~m}^{3}$ de água para lavagem por tonelada de cana moída. Como a unidade de referência é para 15,72 toneladas de cana (relativa a 1 tonelada de álcool), o consumo da água de lavagem da cana é de 125,760 toneladas para a produção de 1 tonelada de álcool.

- Água de embebição:

Pelos dados primários, o consumo médio de água de embebição é de $4.800 \mathrm{~m}^{3} /$ dia. A produção relacionada a esse consumo é de 2 milhões de litros de álcool por dia. Portanto, para 1.250 litros, equivalentes a 1 tonelada de álcool, o consumo de água de embebição é de 3.000 kg.

- Água de lavagem das dornas de fermentação:

Pelos dados primários, há o consumo de $20 \mathrm{~m}^{3}$ de água para a lavagem das dornas de fermentação, por tonelada de cana. Portanto, para 15,72 toneladas de cana (relativas a 1 tonelada de álcool), o consumo é de 314,40 $\mathrm{kg}$.

- Água de resfriamento da fermentação:

Pelos dados primários, são necessários 50 litros de água, por $\mathrm{m}^{3} \mathrm{de}$ álcool, para o resfriamento na fermentação. Portanto, para 1.250 litros de álcool, há o consumo de $62,50 \mathrm{~kg}$ de água de resfriamento da fermentação.

- Água de resfriamento dos condensadores:

A partir dos dados primários do consumo de 50 litros de água de resfriamento dos condensadores, por $\mathrm{m}^{3}$ de álcool, calculou-se o consumo para 1 tonelada de álcool, o qual é $62,50 \mathrm{~kg}$.

- Óleo lubrificante:

Pelos dados de Macedo et al. (2004), são consumidos 13,37 g de óleo lubrificante por tonelada de cana. Portanto, para 15,72 toneladas, é consumido $0,21 \mathrm{~kg}$ de lubrificante.

- Quaternário de amônia: 
Funcionando como biocida, o quaternário de amônia é utilizado, pelos dados primários, na concentração de $1,5 \mathrm{ppm}$ do álcool produzido, o que equivale, para 1 tonelada, a $0,0015 \mathrm{~kg}$.

- Polímero para decantação:

Pelos dados primários sobre o polímero para decantação, há o consumo de 1,5 ppm do álcool produzido, o que equivale, para 1 tonelada, a 0,0015kg.

- Ácido sulfúrico $\left(\mathrm{H}_{2} \mathrm{SO}_{4}\right)$ :

De acordo com Macedo et al. (2004), são utilizados 9,05g de ácido sulfúrico por litro de álcool produzido. Portanto, para 1.250 litros de álcool (referente a 1 tonelada), são consumidos $11,31 \mathrm{~kg}$ de $\mathrm{H}_{2} \mathrm{SO}_{4}$.

- Óleo antiespumante:

A partir de dados primários brutos, há o consumo de $120 \mathrm{~kg}$ de óleo antiespumante para a produção de 1.000 .000 de litros de álcool. Portanto, para 1.250 litros, o consumo é de $0,15 \mathrm{~kg}$.

- Antibióticos Virgiamicina e Hjkamoran:

Com os dados primários sobre o consumo de $3 \mathrm{mg}$ de antibióticos por litro de álcool, calculou-se o consumo para 1.250 litros, obtendo-se 0,00375 kg.

- Uréia:

A partir dos dados primários sobre o consumo de uréia de $3 p p m$ do álcool produzido, o consumo para 1 tonelada de álcool é de 0,003 kg.

- Adubo Usifos:

Os dados primários indicam consumo de 18 toneladas de adubo para a fermentação de 180.000.000 litros de álcool. Portanto, para 1.250 litros, o consumo de adubo é de $0,125 \mathrm{~kg}$.

- Soda:

Os dados primários indicam consumo de soda de 2 ppm por litro de álcool. Portanto, para 1 tonelada de álcool, o consumo é de 0,0025 kg.

- Energia elétrica: 
De acordo com os dados primários, para a produção de 600.000 litros de álcool por dia, utilizam-se 110 toneladas de vapor por hora. Portanto, para 600.000 I de álcool, equivalente a $480.000 \mathrm{~kg}$ (massa específica de 0,8 kg/l), consomem-se 2.640 toneladas de vapor, distribuídos metade em forma de vapor e metade em energia elétrica, a qual é necessária para os motores elétricos da indústria. Dessa forma, para se produzir 1 tonelada de álcool, são consumidas 5,5 toneladas de vapor (tv), sendo 2,75 tv consumidas diretamente, na forma de vapor, e 2,75 tv consumidas na forma de energia elétrica. Assim, considerando-se a média dos dados primários de geração de $0,125 \mathrm{MWh}$ por tonelada de vapor, são consumidos, em forma de energia elétrica, 0,344 MWh ou 1.238,4 MJ.

O tratamento dos dados dos aspectos de saída da análise de inventário para a produção industrial do álcool etílico hidratado combustível seguiram as seguintes considerações:

- as quantidades de saída de água de lavagem da cana, água de resfriamento dos condensadores da destilaria e água de lavagem das dornas de fermentação são iguais às quantidades consideradas na entrada;

- para a produção de 1 tonelada de álcool, segundo os dados primários, a quantidade gerada de bagaço de cana-de-açúcar é de 4,085 toneladas;

- $\quad$ a quantidade média gerada de vinhaça é, segundo Cetesb (1985) e Unido (1997), de 15 litros por litro de álcool produzido, com massa específica, aproximadamente, igual a 1 ;

- as quantidades de saída de ácido sulfúrico, óleo antiespumante, soda e óleo lubrificante das moendas são iguais às quantidades de entrada;

- a quantidade gerada de torta de filtro, segundo Ometto, A. (2000), é de $40 \mathrm{~kg}$, para cada tonelada de cana-de-açúcar moída;

- a emissão de $\mathrm{CO}_{2}$ gerada na fermentação do caldo não foi considerada, pois não são quantidades expressivas, não se 
obtiveram dados confiáveis, além de ela ser absorvida durante o crescimento da cana.

- $\quad$ Atividade 6: Geração de Vapor e de Energia Elétrica

A atividade de geração de vapor e de energia elétrica é realizada por meio da queima do bagaço da cana-de-açúcar em caldeiras, pela utilização de água para geração de vapor e por geradores para a produção de energia elétrica.

As considerações relacionadas ao tratamento dos dados desta atividade são:

- $\quad$ segundo os dados primários, para a produção de 1 tonelada de álcool, geram-se 4,085 toneladas de bagaço;

- segundo os dados primários, $1 \mathrm{~kg}$ de bagaço gera $2 \mathrm{~kg}$ de vapor, portanto 4,085 $\mathrm{t}$ de bagaço geram 8,17 toneladas de vapor (tv). Como são consumidas, no processo industrial, 2,75 tv, em forma de energia, e mais 2,75 tv para o processo industrial, há o excedente de 2,67 tv $(32,68 \%)$ para a geração de eletricidade. Considerando a média dos dados primários de geração, de 0,125 MWh por tonelada de vapor, é gerado 0,334 MWh de eletricidade excedente para 1 tonelada de álcool. Dessa forma, são alocados, para o álcool, $67,32 \%$ dos aspectos e impactos ambientais da atividade de cogeração, não se considerando o calor perdido;

- pelos dados primários, para cada $1 \mathrm{~kg}$ de bagaço, são consumidos $2 \mathrm{~kg}$ de água de reposição;

- de acordo com os dados primários, a quantidade de água para a refrigeração de óleos dos mancais do turbogerador e de água no trocador de calor no gerador é de $20 \mathrm{~m}^{3} / \mathrm{MWh}$. Como se gera 0,678 MWh de energia com a quantidade de bagaço utilizado para a energia elétrica $(2,71 \mathrm{t}$ de bagaço), o consumo de água para tais fins é de $13,56 \mathrm{t}$. 
- a quantidade total, segundo dados primários, de óleo lubrificante utilizado é de $2000 \mathrm{~kg}$ para 180.000 .000 de litros de álcool. Desse modo, para 1.250 litros, é necessário $0,01 \mathrm{~kg}$.

- de acordo com Fiesp (2001), a quantidade de cinzas geradas na queima do bagaço é de $6,2 \mathrm{~kg}$ para cada $260 \mathrm{~kg}$ de bagaço. Portanto, para $4.085 \mathrm{~kg}$ de bagaço, produzem-se $97,41 \mathrm{~kg}$ de cinzas;

- a quantidade de $\mathrm{CO}_{2}$ emitido pela queima do bagaço é indicada como emissão atmosférica, a fim de se verificar a quantidade que se emite nas chaminés, apesar de reabsorvido no crescimento da cana. Tal emissão não é contabilizada para a avaliação de efeito estufa e demais impactos pelo EDIP, contudo é considerada para a Exergia, pois esta avalia o trabalho que o meio deve absorver, independente de a quantia emitida no meio retornar a esse sistema;

- o vapor produzido é utilizado na atividade 5 , portanto não é considerado emissão atmosférica.

- $\quad$ Atividade 7: Fertirrigação

Considerações adotadas para os fluxos de entrada:

- a quantidade de vinhaça utilizada é a mesma que sai da produção do álcool (15 litros de vinhaça por litro de álcool);

- para a torta de filtro, foi considerada a quantia que sai do processo de produção industrial do álcool $(40 \mathrm{~kg}$ de torta por tonelada de canade-açúcar);

- adicionam-se, segundo os dados primários, 524 litros de água por hectare. Portanto, para 0,24 ha, consomem-se 125,76 kg;

- a quantidade de nutrientes adicionais utilizados tem base em Macedo et al. (2004).

A distância total percorrida pelos tratores agrícolas na atividade 7 foi estimada pela média ponderada do consumo dos tratores e pela velocidade média ponderada da potência deles. A partir de dados primários, o consumo médio dos tratores, na atividade 7 , é de $24,57 \mathrm{l} / \mathrm{h}$ e, segundo Ripoli (2004), a velocidade média de um trator de 100cv (a média ponderada das potências), 
para as operações de campo necessárias, é de $5,5 \mathrm{~km} / \mathrm{h}$. Com o dado primário de consumo de 2,7 litros de diesel, no total das operações da atividade 7, a distância total percorrida nas operações, pelos equipamentos agrícolas, é de $0,6044 \mathrm{~km}$ ou $604,4 \mathrm{~m}$.

A fertirrigação da vinhaça é feita por declividade e por aspersão, sendo o transporte da torta de filtro feito por caminhão. Pelos dados primários, o caminhão consome, para a unidade de referência, 2,89 litros e apresenta o consumo médio de $4 \mathrm{~km} / \mathrm{l}$. Portanto, a distância percorrida pelo caminhão é de $11,56 \mathrm{~km}$.

A quantidade de torta de filtro utilizada, para o fluxo de referência, é de 628,8 kg; contudo o caminhão percorre metade da distância vazio, portanto a massa média transportada de torta de filtro é de $314,4 \mathrm{~kg}$, ou 0,3144 t.

Desse modo, o produto distância percorrida multiplicada pela massa média transportada, para o cálculo dos aspectos relativos ao consumo de diesel do caminhão, a partir do banco de dados do EDIP, é 11,56 km vezes $0,3144 \mathrm{t}$, igual a $3,63 \mathrm{~km} . \mathrm{t}$.

- $\quad$ Atividade 8: Distribuição do álcool etílico hidratado combustível

De acordo com as transportadoras consultadas na região de Ribeirão Preto, SP, o frete do álcool é realizado para o transporte de 30.000 litros, para uma distância de $150 \mathrm{~km}$. Portanto, para 1.250 litros (correspondente a 1 tonelada de álcool), o caminhão percorre uma distância relativa equivalente a $6,25 \mathrm{~km}$.

Assim, o produto distância percorrida multiplicada pela massa média transportada, para o cálculo dos aspectos relativos ao consumo de diesel do caminhão, a partir do banco de dados do EDIP, é 6,25 km vezes $1 \mathrm{t}$, igual a 6,25 km.t.

- $\quad$ Atividade 9: Utilização do álcool etílico hidratado combustível

As trocas ambientais nesta fase ocorrem com o uso do álcool combustível em automóveis, estando os dados das emissões de acordo com Copersucar (1989). A quantidade de $\mathrm{CO}_{2}$ emitida na utilização do álcool não foi 
considerada, pois ela é absorvida durante o crescimento da planta e não se obteve este dado para a avaliação exergética.

Neste estudo, é suposto que o álcool combustível seja utilizado em um carro $1.600 \mathrm{cc}$, com um consumo médio de $8 \mathrm{~km} / \mathrm{l}$, segundo a Anfavea (2004), em áreas urbanas e estradas.

As considerações gerais com relação à avaliação emergética são:

- vida útil de 15 anos para todos os equipamentos;

- foram utilizados os dados da análise de inventário na análise emergética. Algumas análises específicas para a Emergia foram realizadas pela área de um hectare e relacionadas para a referência de 1 tonelada de álcool;

- as Emergias do veículo, equipamentos agrícolas e edificações foram consideradas diretamente na avaliação e valoração emergética;

- no caso de o insumo utilizado ser um subproduto interno do sistema, não foi contabilizado na Emergia total do ciclo de vida, para não haver dupla contagem do insumo, seguindo as regras da álgebra emergética.

\section{Limitação}

As maiores incertezas quanto ao período de aplicação deste estudo decorrem das alterações na quantidade de cana queimada e das áreas de colheita mecanizadas, referentes, especificamente, à atividade de colheita da cana-de-açúcar.

A avaliação de impactos baseia-se no consumo de álcool dos veículos de $8 \mathrm{~km} / \mathrm{l}$; por isso quanto maior o consumo pelos automóveis, maiores os potenciais de impactos, conseqüentemente.

Outra limitação é a utilização de bancos de dados europeus para a atividade de extração do calcário e de consumo do diesel no maquinário agrícola, nos ônibus e nos caminhões. Contudo os principais dados das atividades mais importantes do ciclo foram coletados de fontes primárias. 


\section{$\underline{\text { Requisitos da qualidade dos dados iniciais }}$}

Os dados brutos das atividades das nove unidades de processo foram obtidos de fontes primárias, de especialistas e da bibliografia, como também pelo banco de dados do EDIP.

\section{$\underline{\text { Tipo de análise crítica }}$}

A análise crítica deste estudo foi realizada a partir de diversas consultas a especialistas nacionais e internacionais, especialmente durante o estágio realizado na Universidade Técnica da Dinamarca (DTU).

\section{Tipo e formato do relatório requerido para o estudo}

Os resultados são apresentados de acordo com a estrutura metodológica de um estudo de ACV, citada em Schaltegger (1996), Ciambrone (1997), Setac (1991), Udo de Haes et al. (2002), ISO (1997), ABNT (2001), ABNT (2004a), ABNT (2004b) e Wenzel et al. (1997).

\subsection{Análise de inventário do ciclo de vida}

A análise de inventário deste estudo de ACV é realizada de acordo com a divisão das atividades do ciclo de vida do etanol hidratado combustível, nas nove unidades de processo. O objetivo do inventário é obter informações ambientalmente relevantes para as unidades de processo, de acordo com a definição do escopo, expresso como as trocas ambientais dos processos envolvidos no sistema do produto.

O resultado da análise de inventário do ciclo de vida está apresentado nas tabelas 10 à 18, como forma de se obter uma melhor organização dos dados e um melhor entendimento sobre cada atividade do ciclo. Os resultados apresentam o dado bruto coletado, a unidade de referência para o tratamento deste e a quantidade relativa à unidade funcional. 


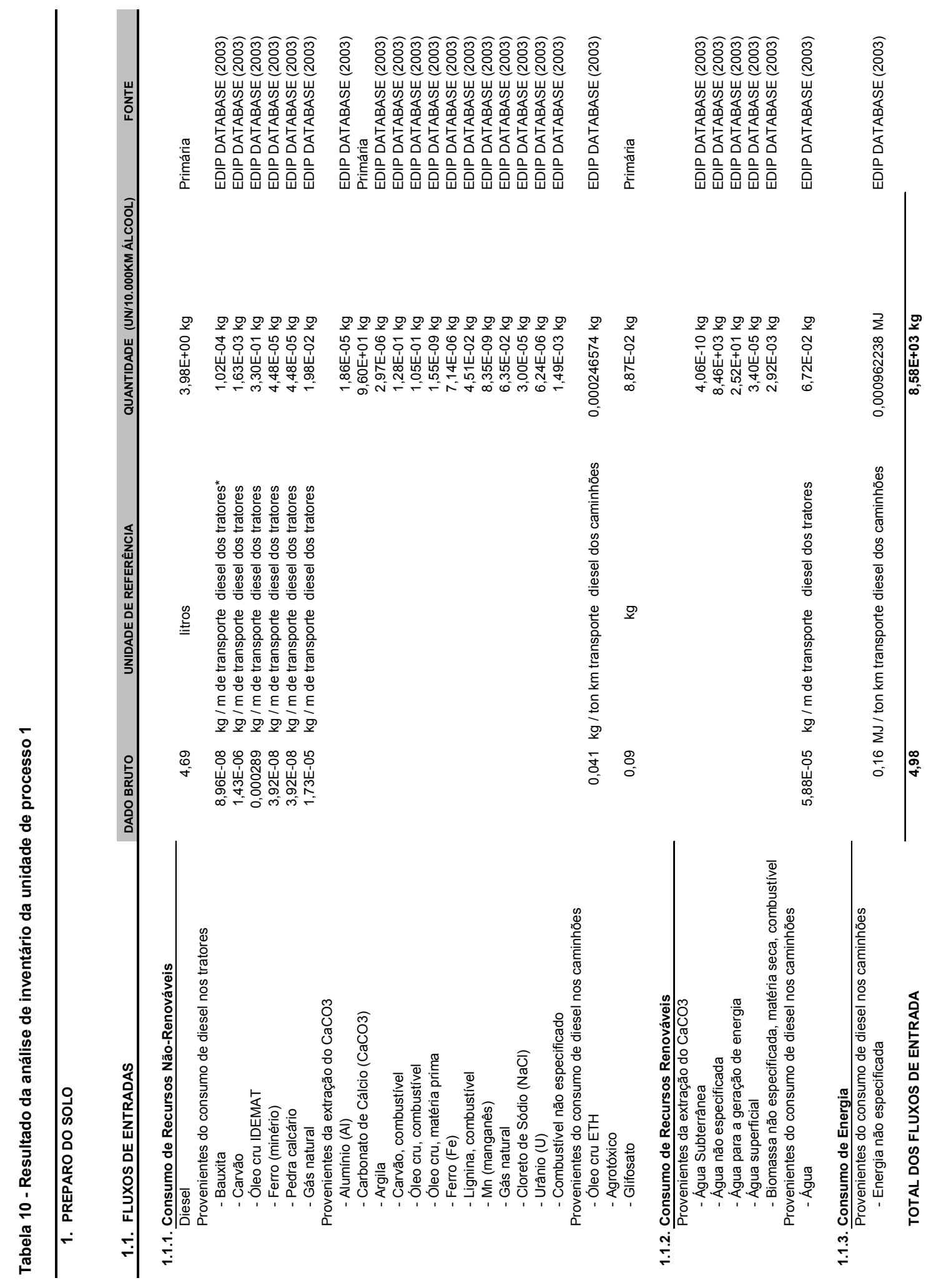




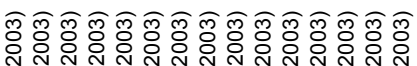

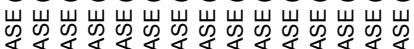

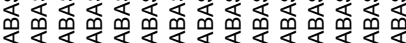

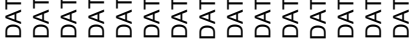

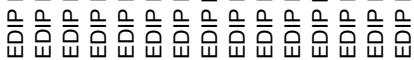

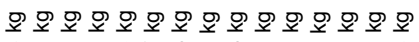

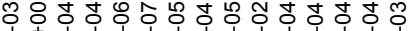

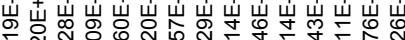

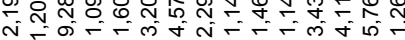

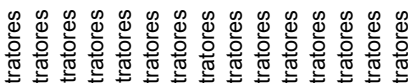

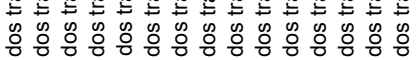

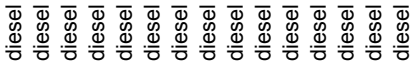

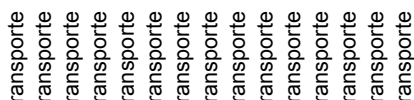

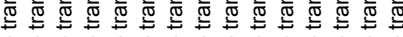
용 용

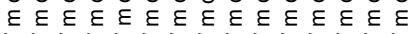

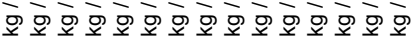

웅응ㅎㅇㅇㅇㅇ웅ㅇㅇㅇㅇㅇㅇㅇㅇㅇㅇㅎㅇㅎㅇㅇㅇㅇ

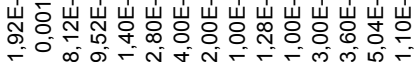

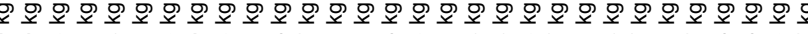

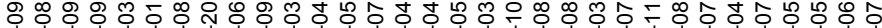

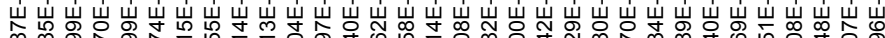

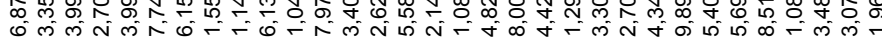

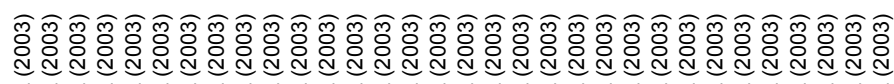

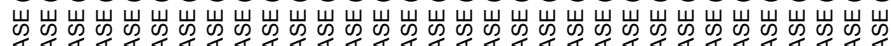
m mom

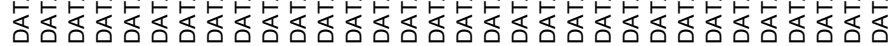

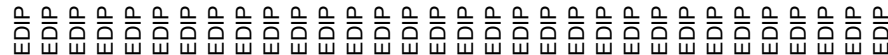

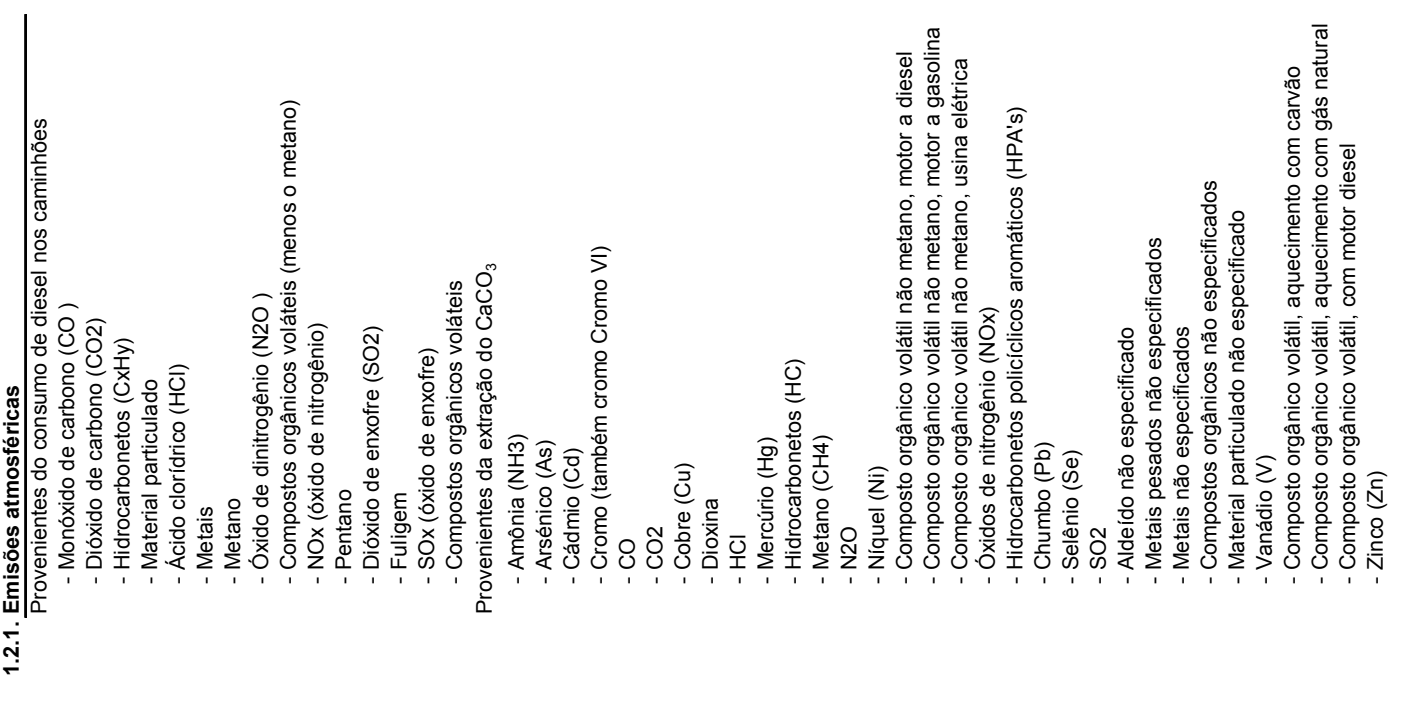




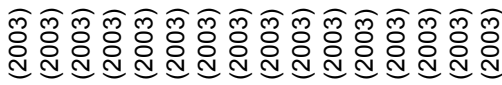

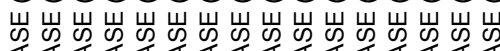

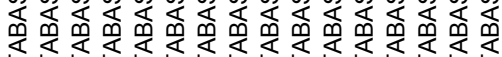

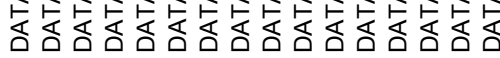

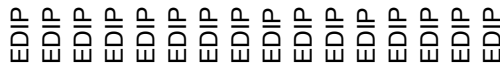
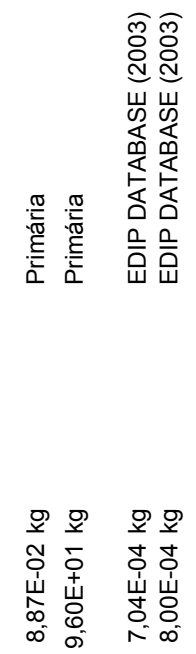

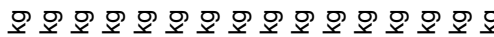

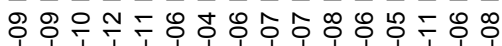

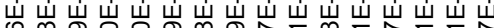

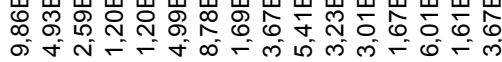

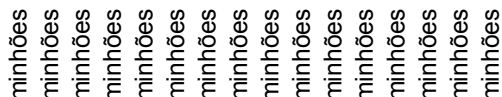

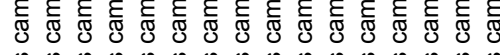

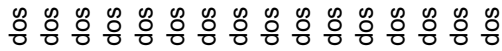

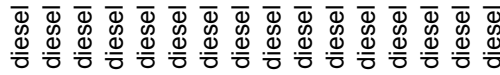

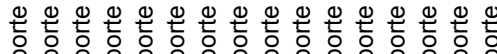

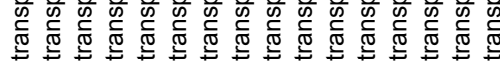

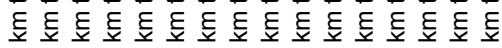
ๆ

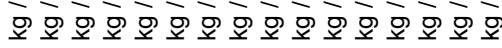

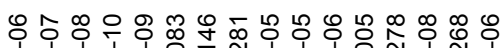

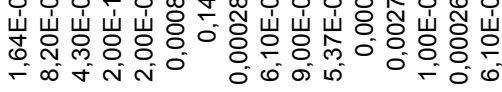

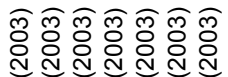

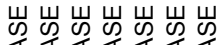

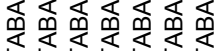

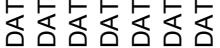
言言言高高高高

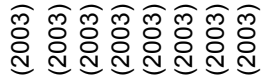

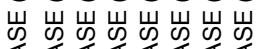

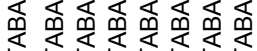

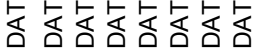

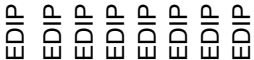

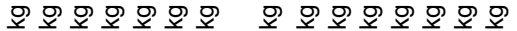

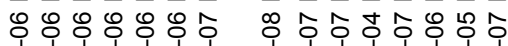

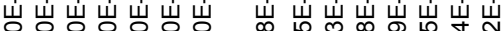

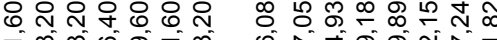

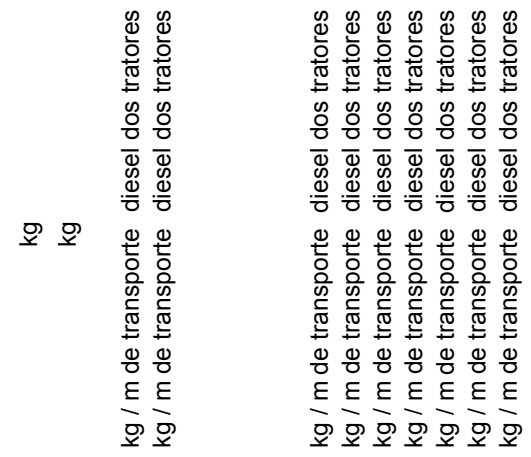

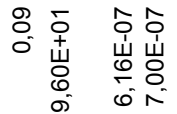

옹ㅇㅇㅇㅇㅇㅇㅇㅇㅇㅇㅇㅡ 岁岁峁岁岁岁岁

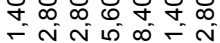
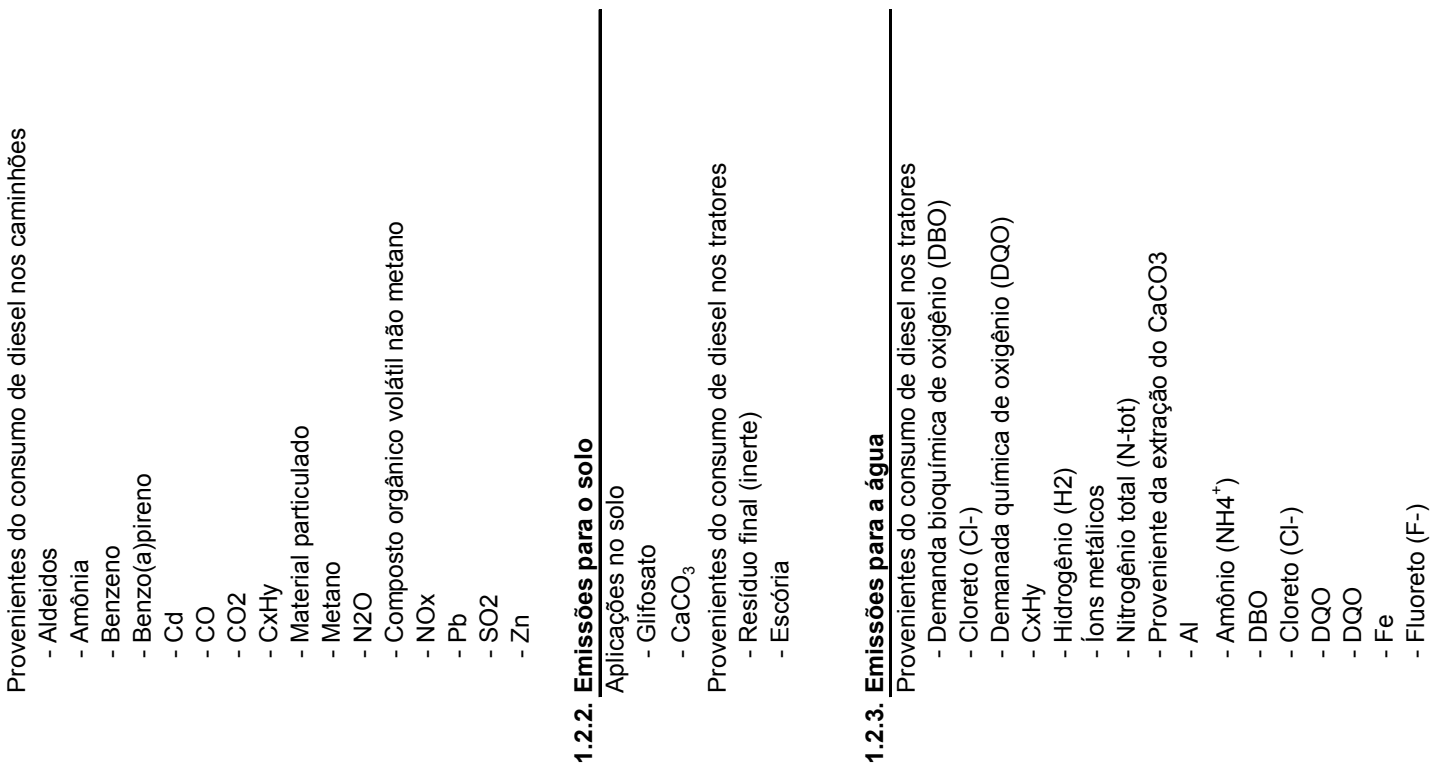


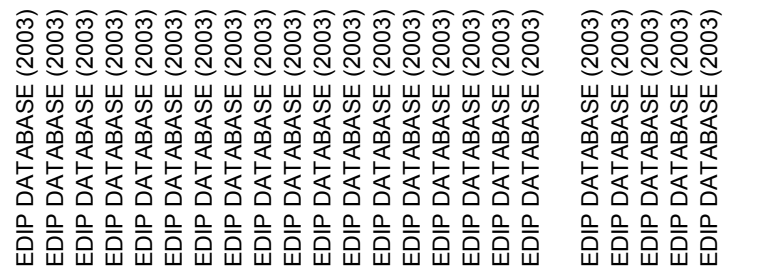

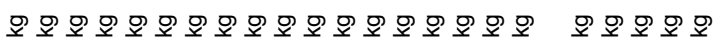

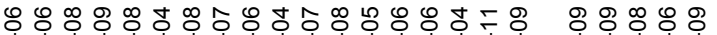

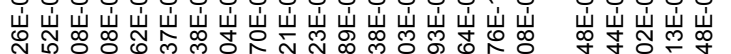
N N

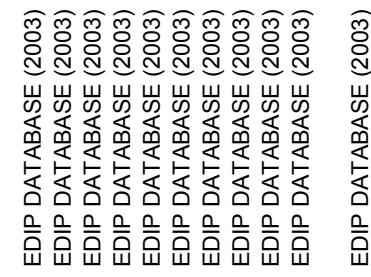

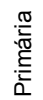

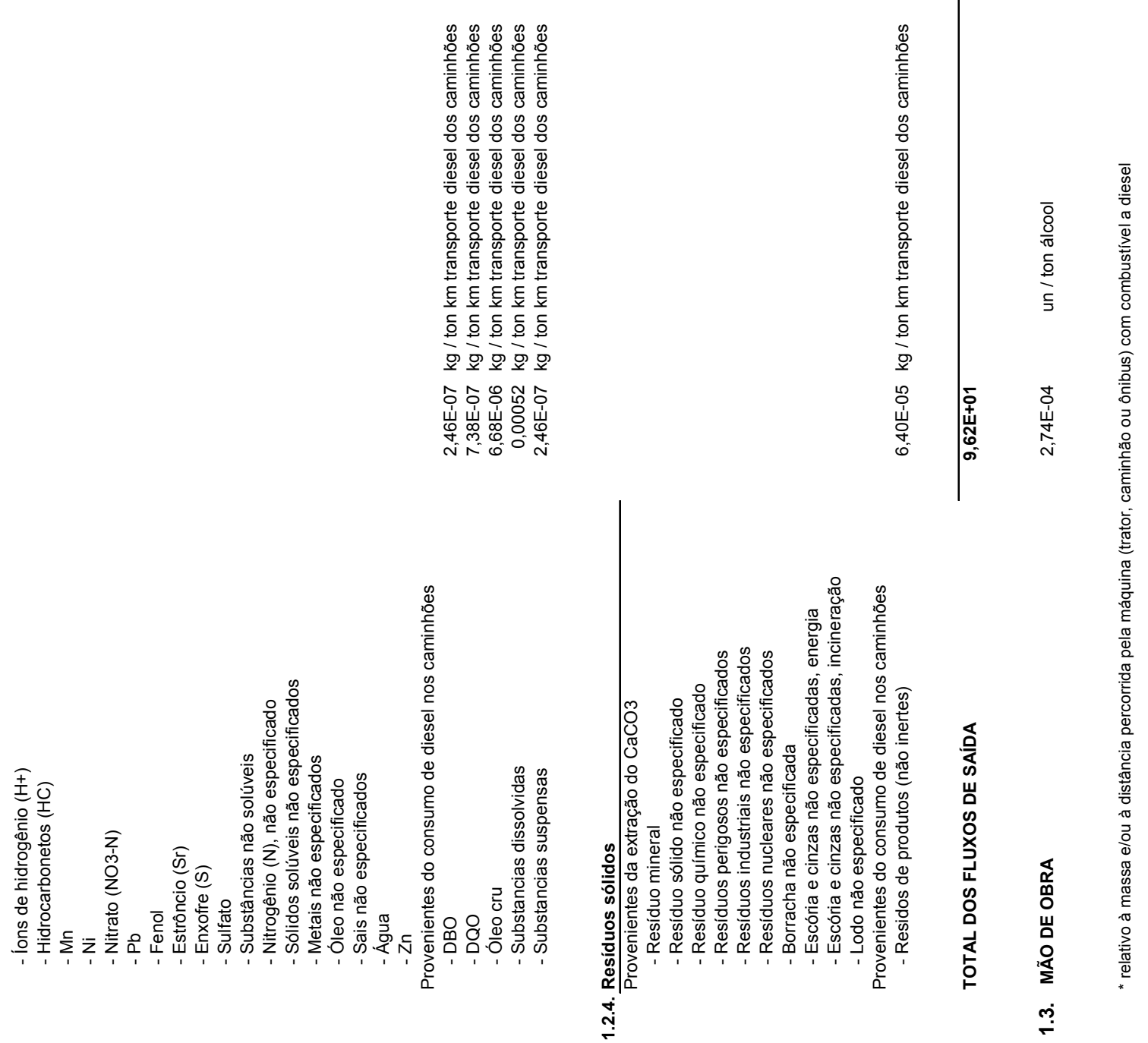




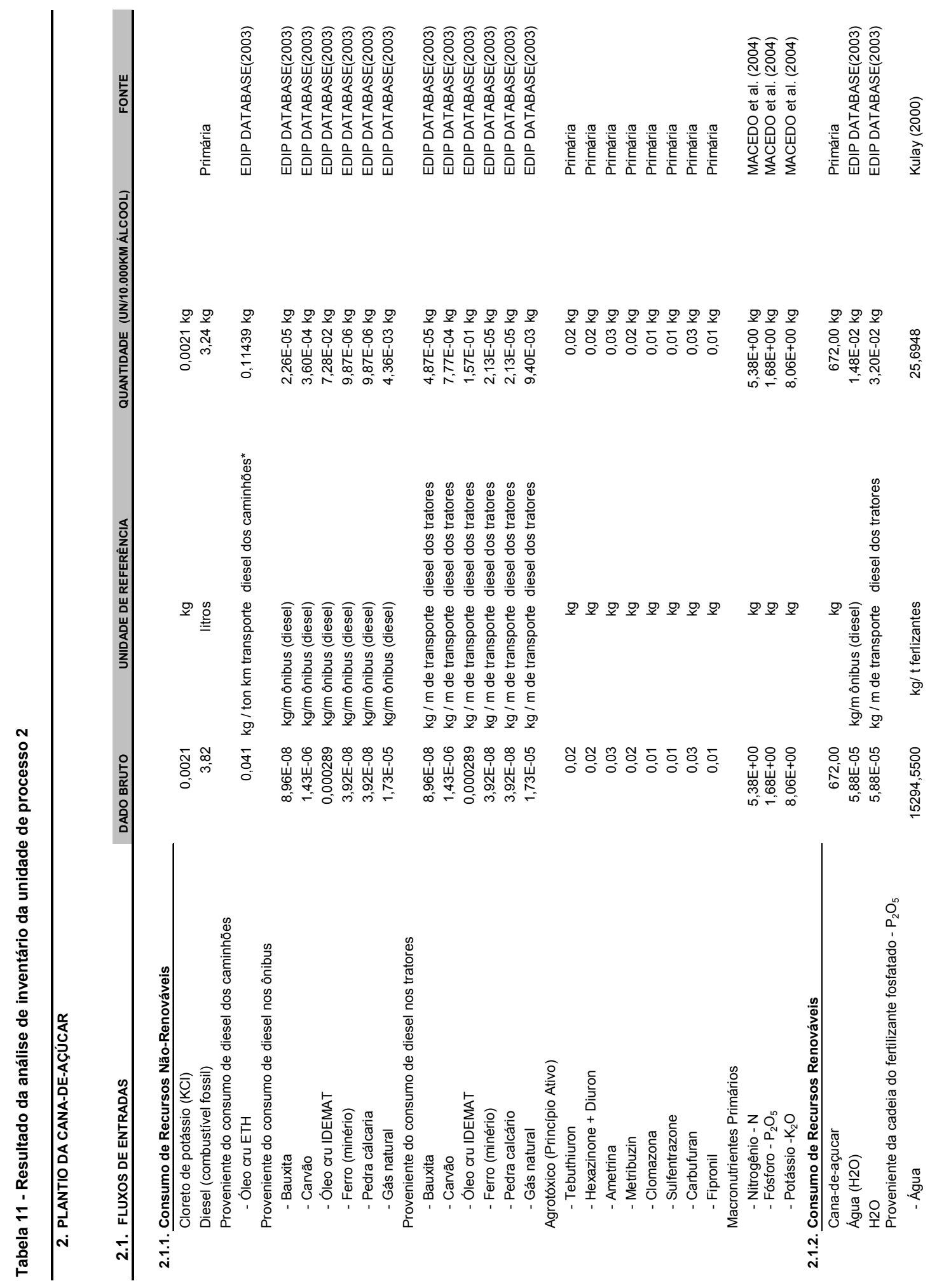




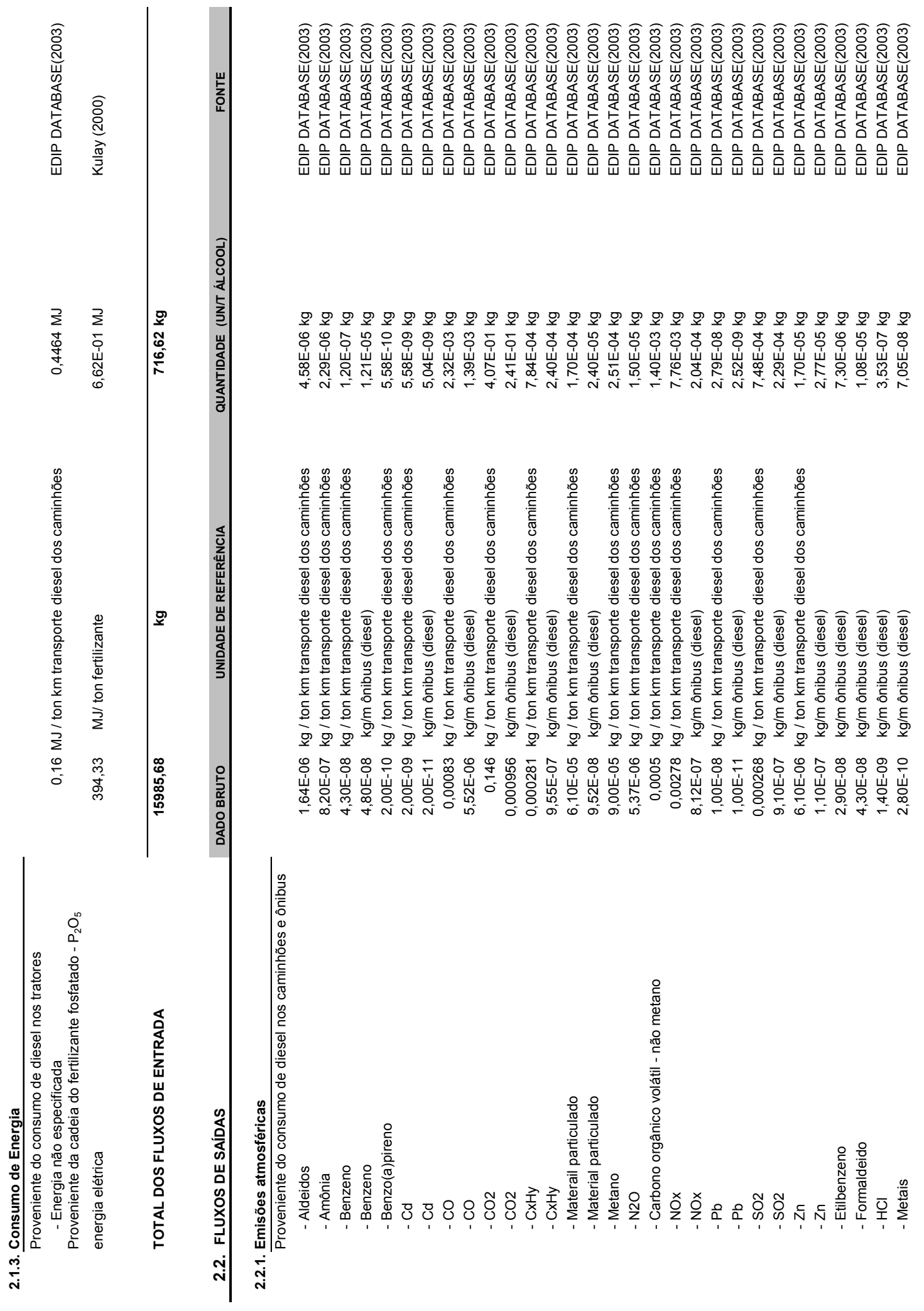




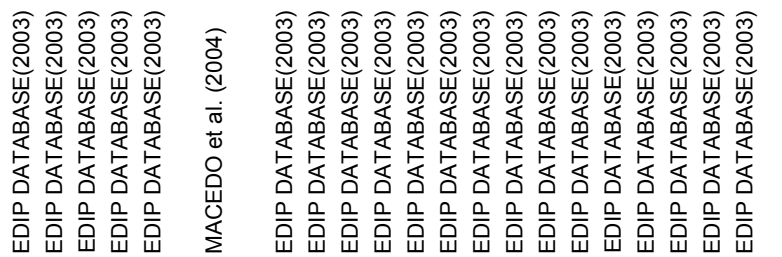

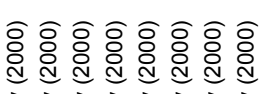

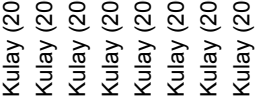

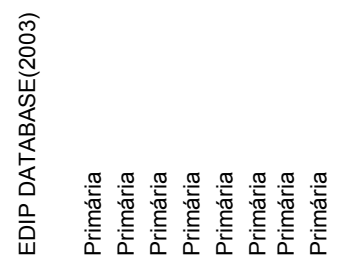

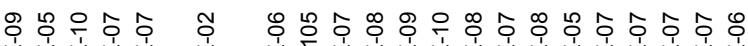

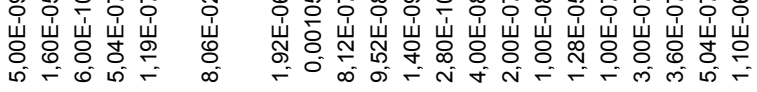

0
0
0
0
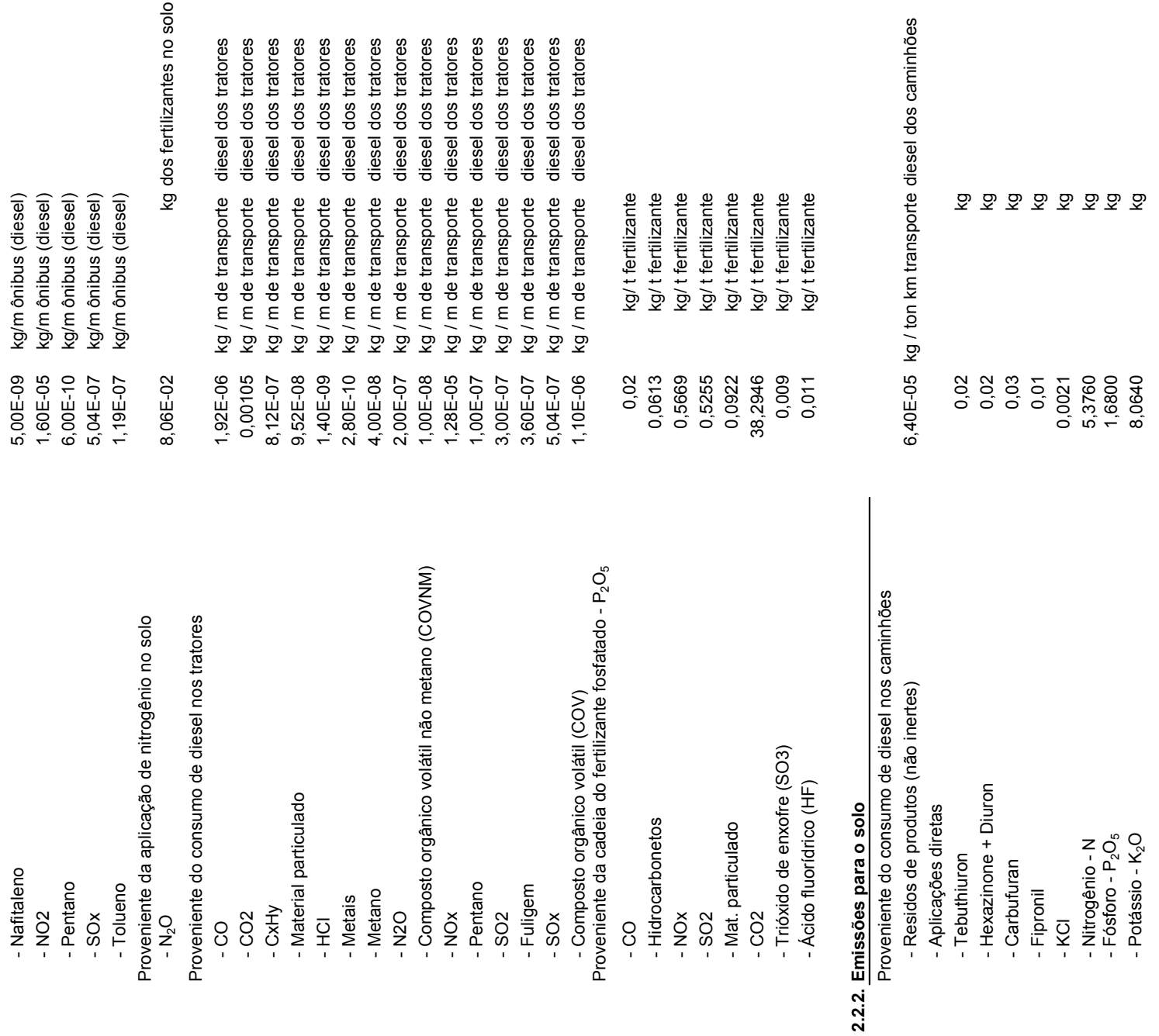


\begin{tabular}{|c|c|c|c|c|c|}
\hline 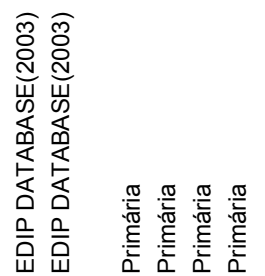 & 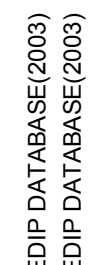 & 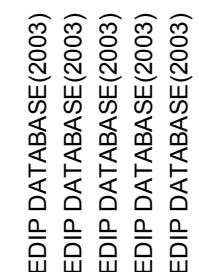 & 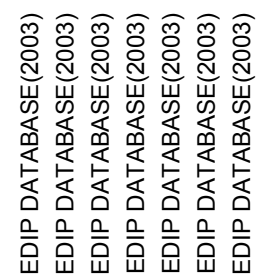 & 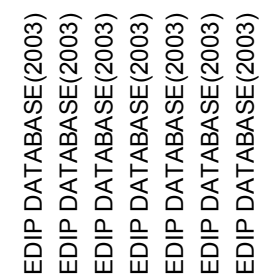 & \\
\hline
\end{tabular}

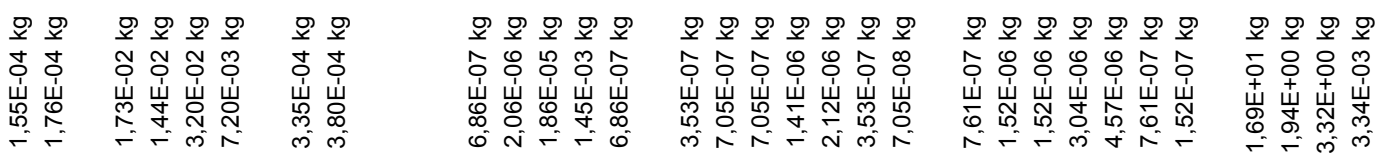
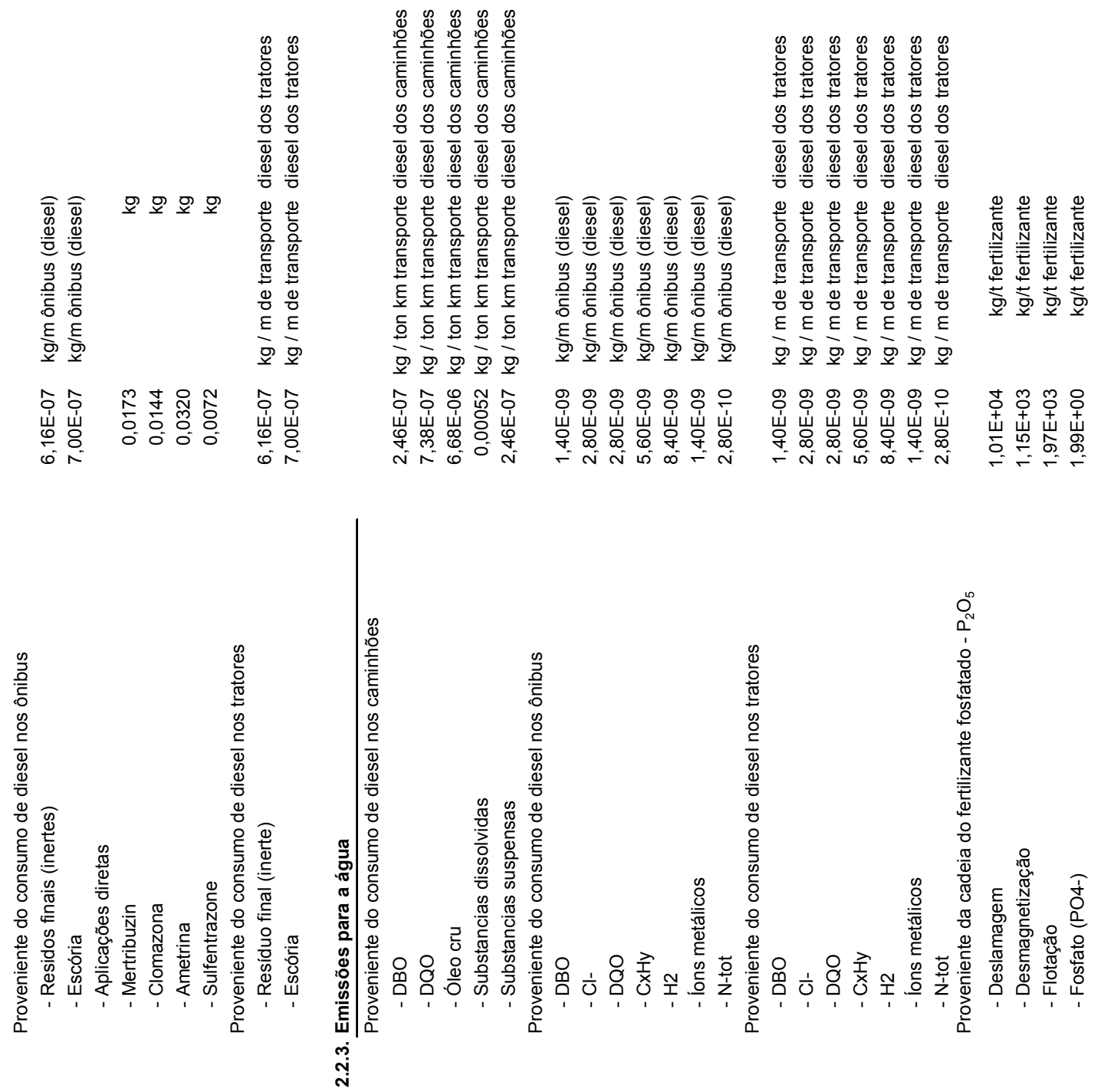


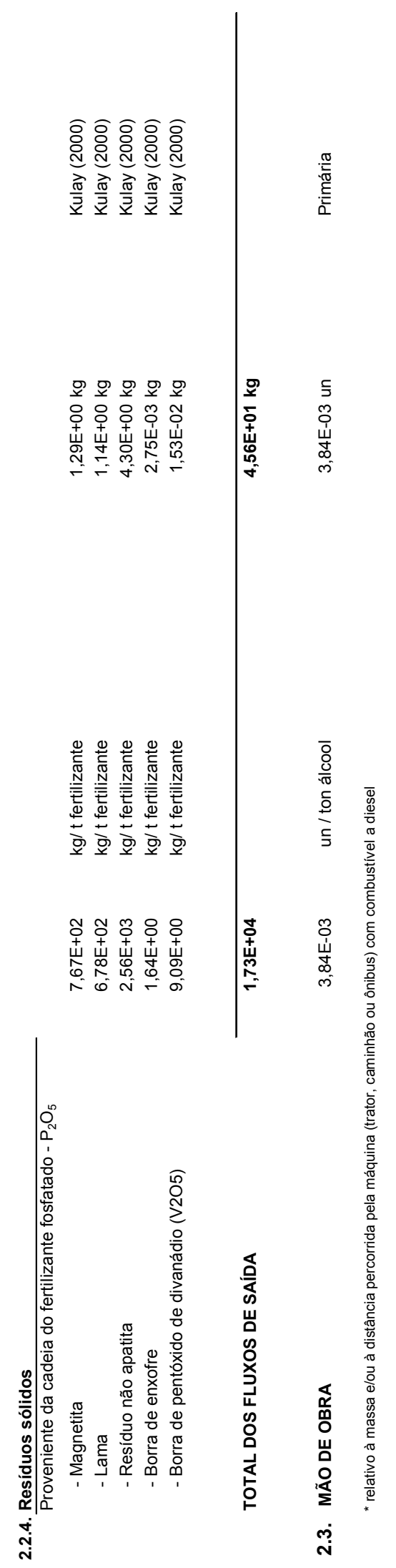




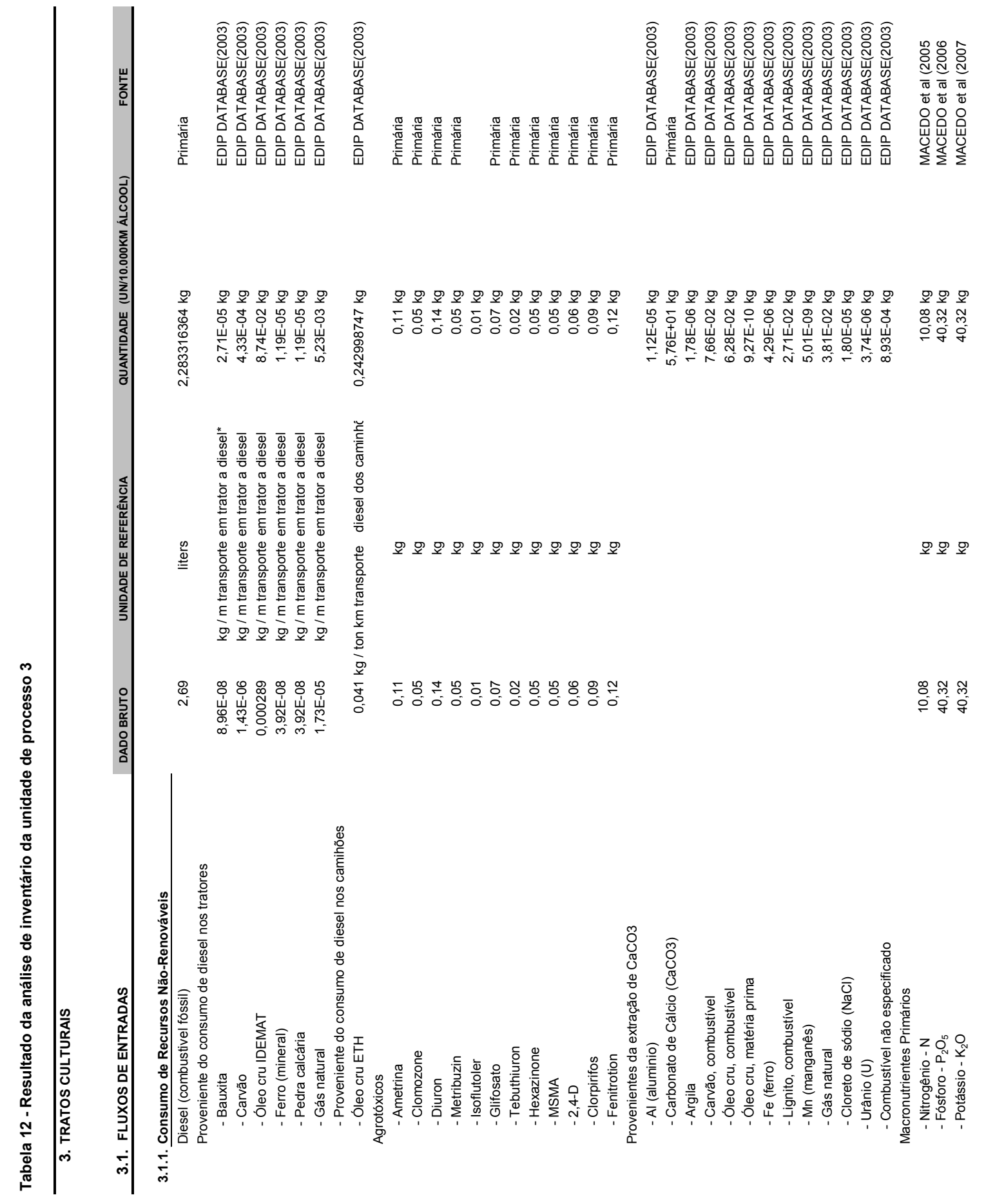




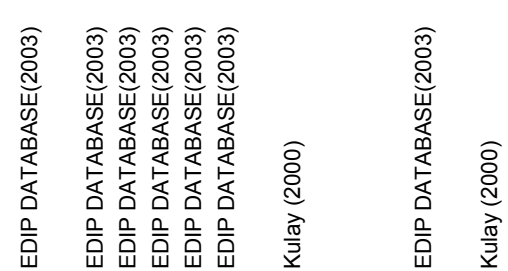

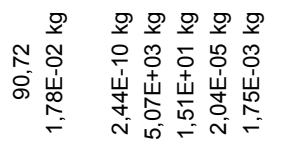
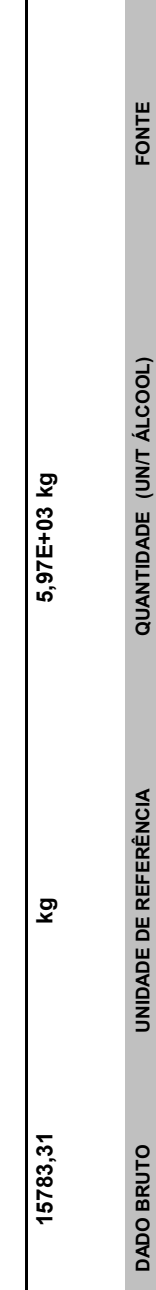

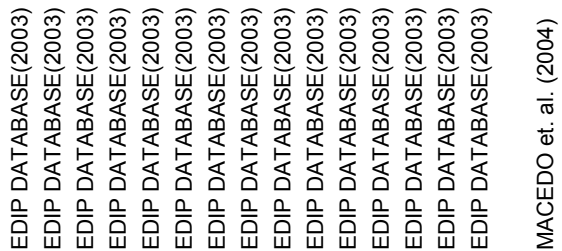

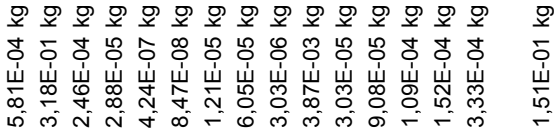

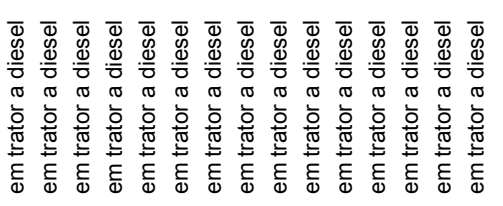

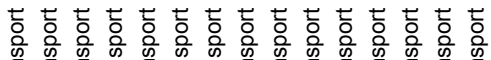

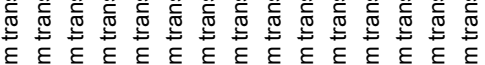

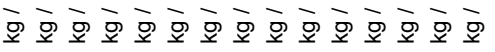

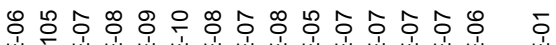

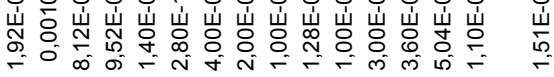

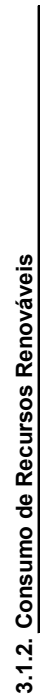
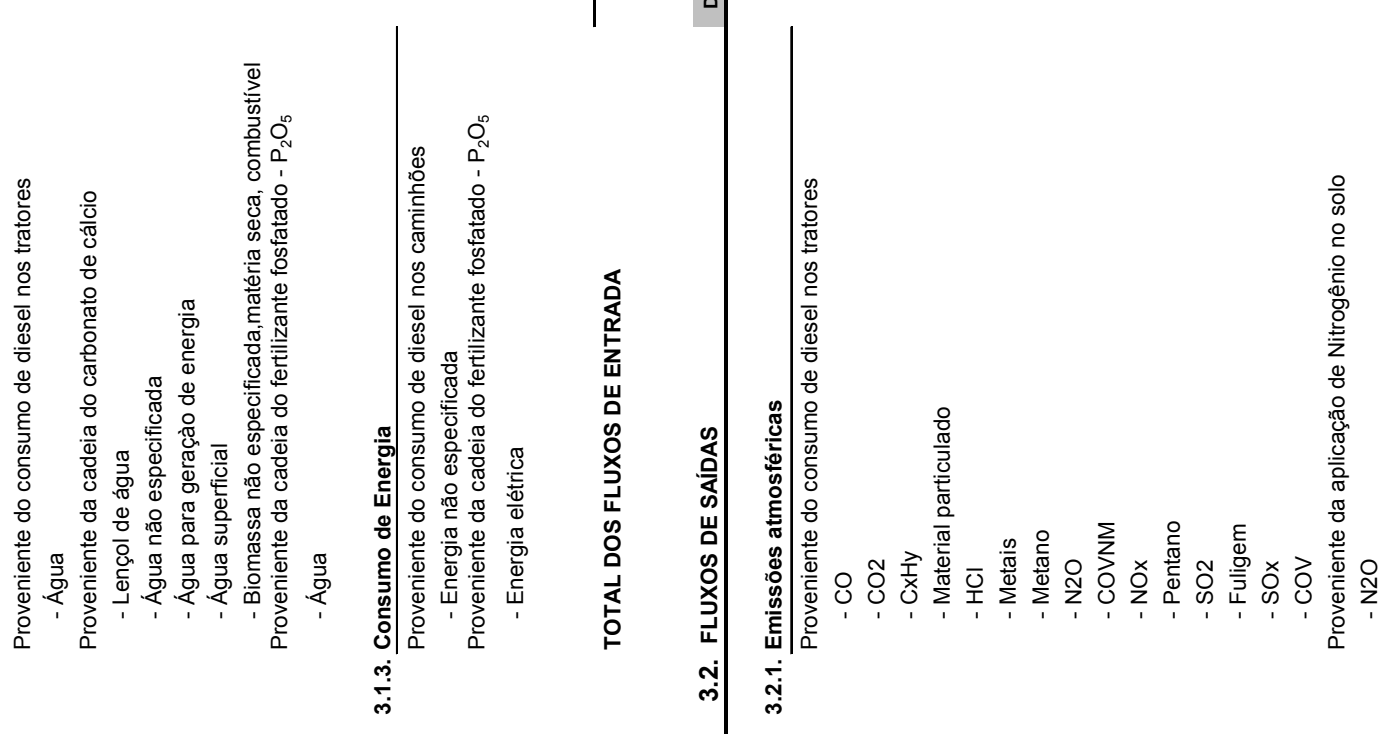

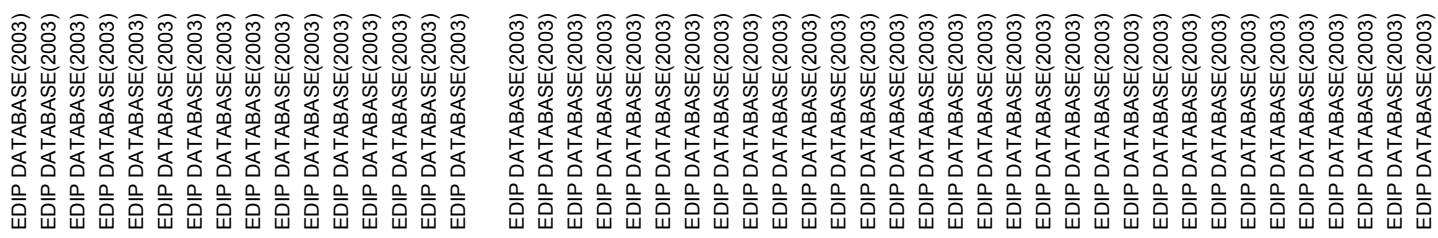

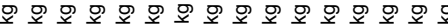

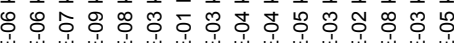
岕岕 崫

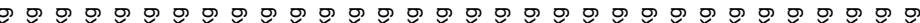

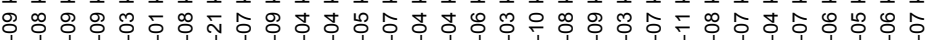
崩
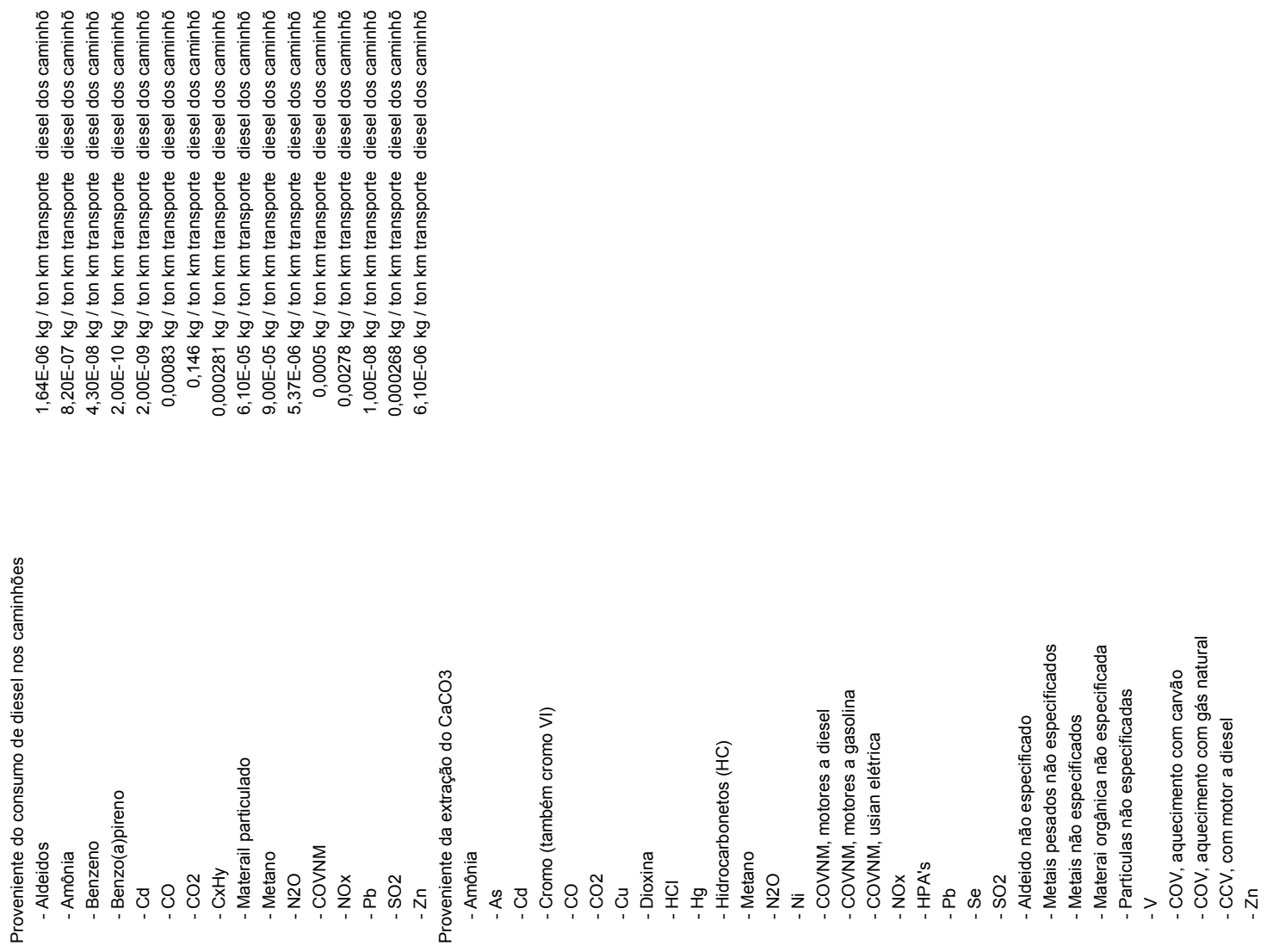


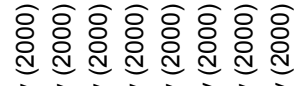

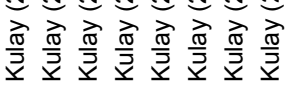

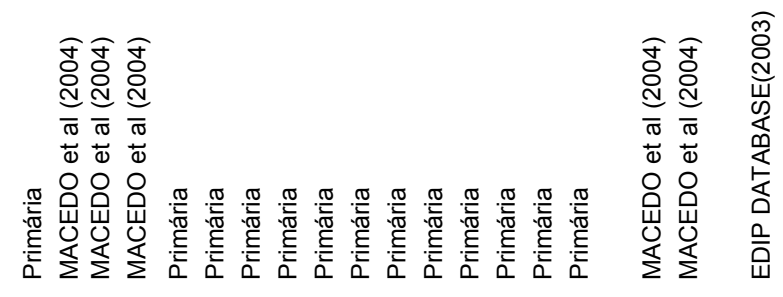

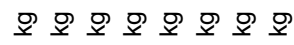

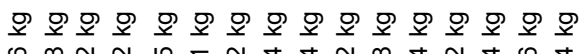

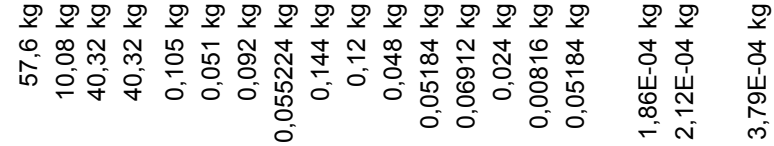

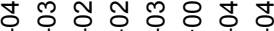

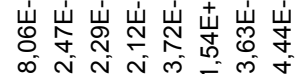

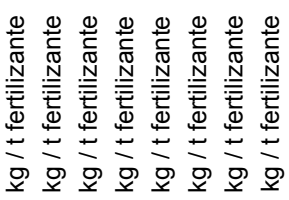

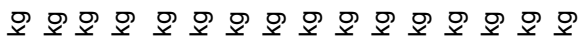

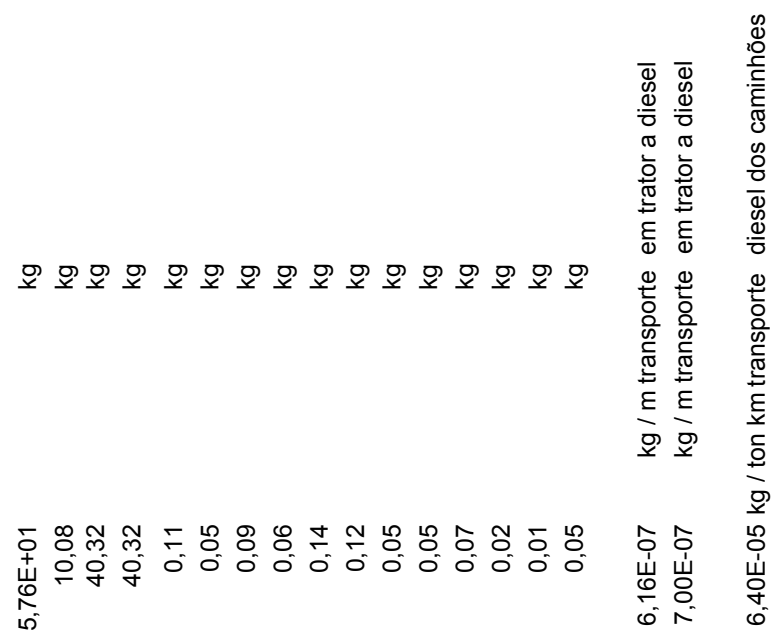

ชิ ชิ

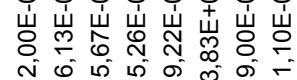
$\begin{array}{llllllllll}0 & \\ 0 & 0\end{array}$
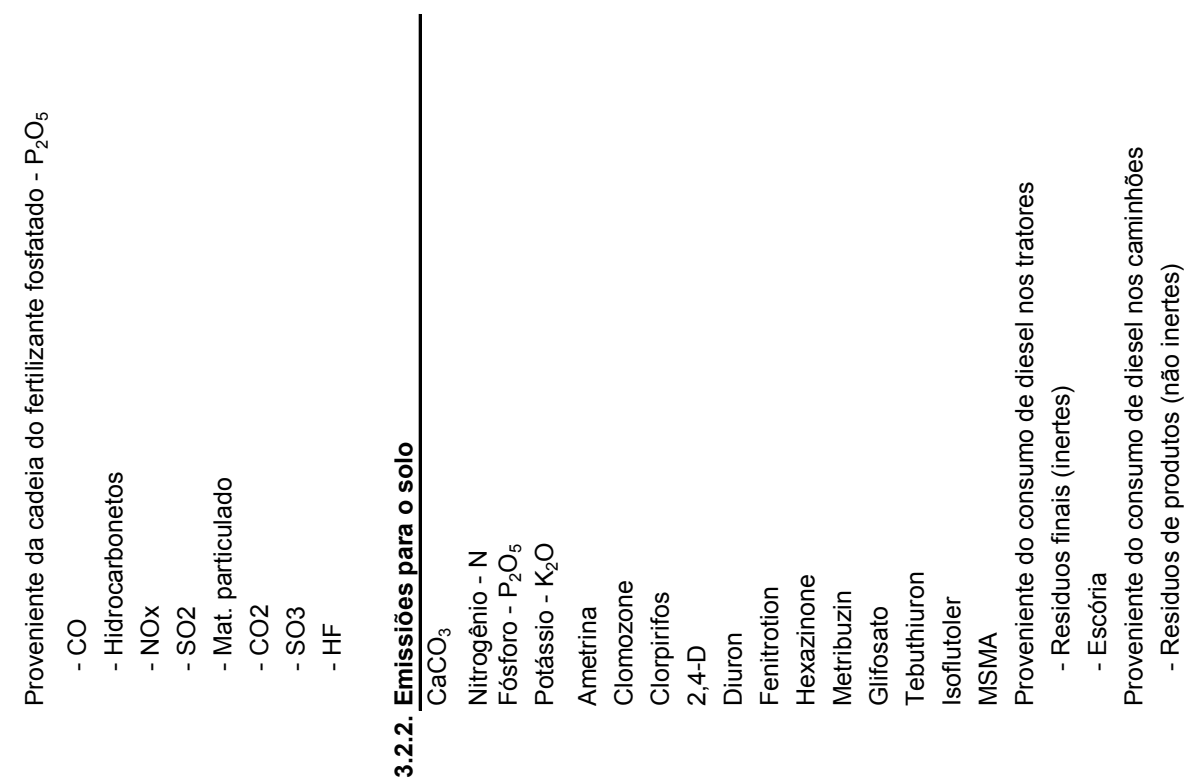


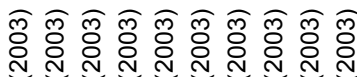

嵌

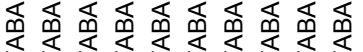

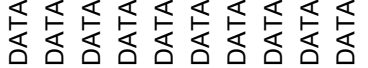

高高高高高高高高高高

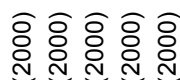

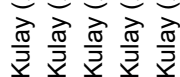

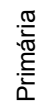

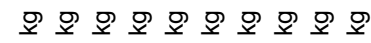

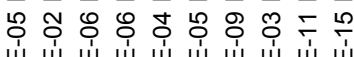

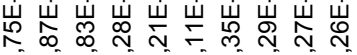

오요요요요오

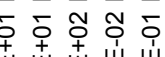

岃嵌岩岩岕

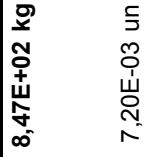

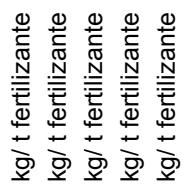

잉용ㅇㅇㅇㅛ

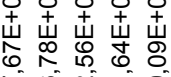

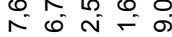
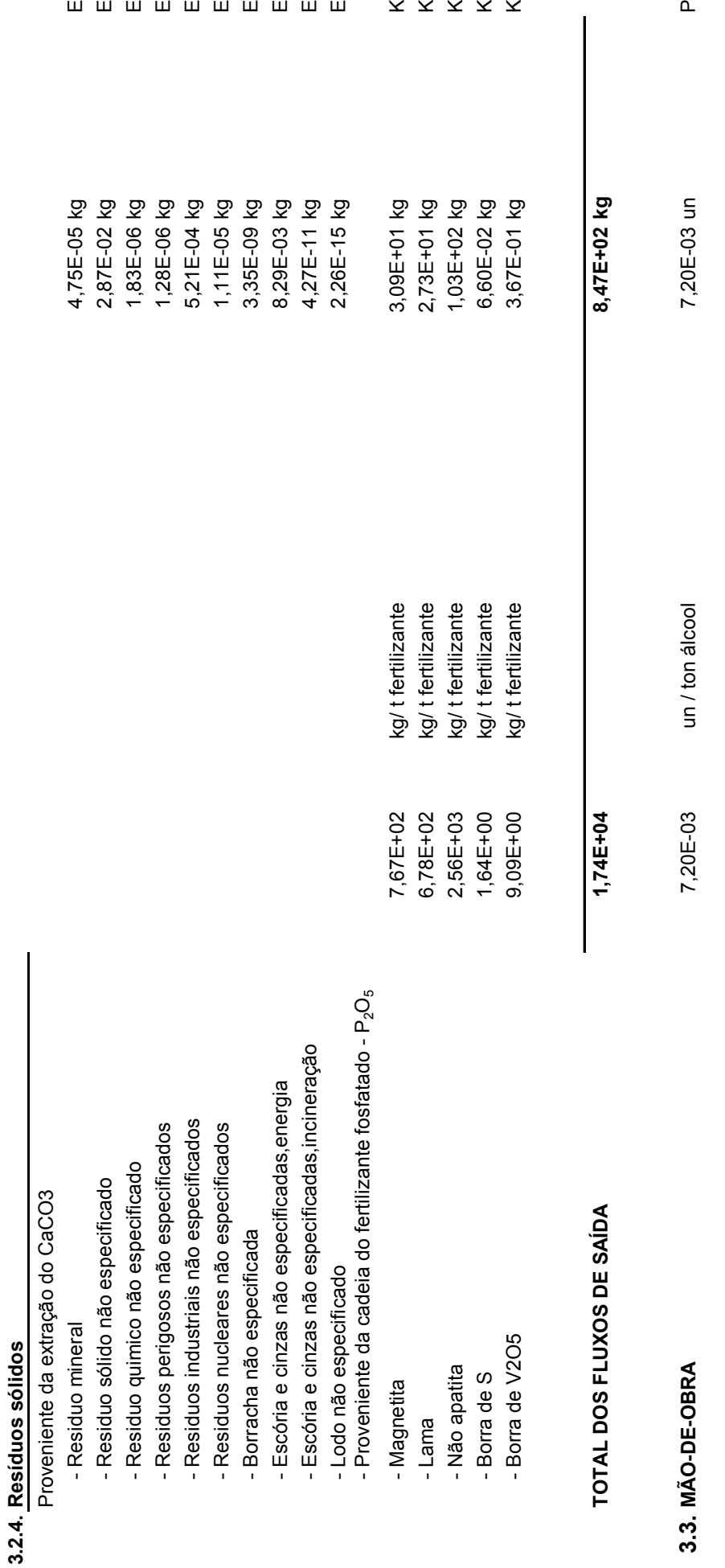


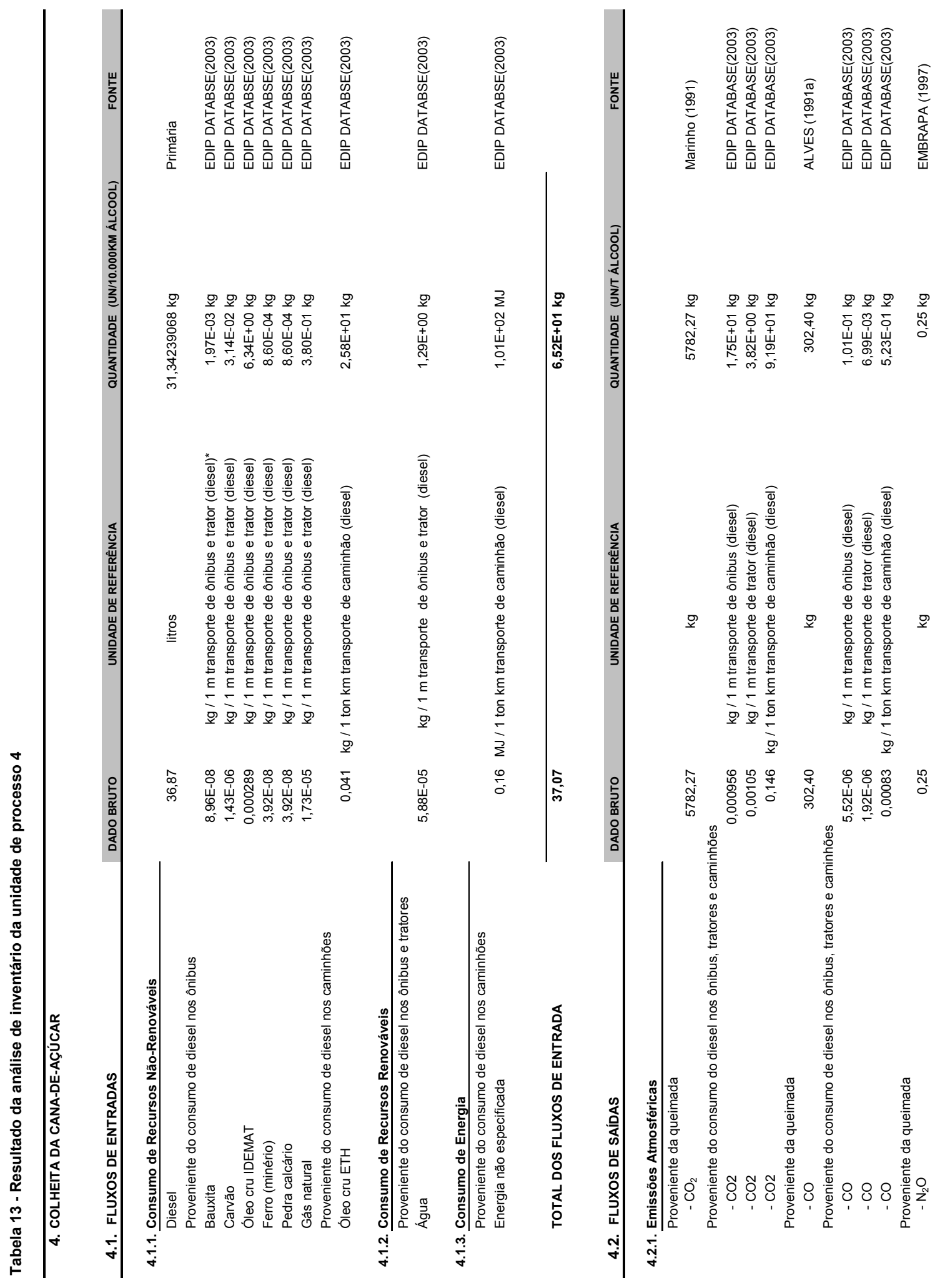




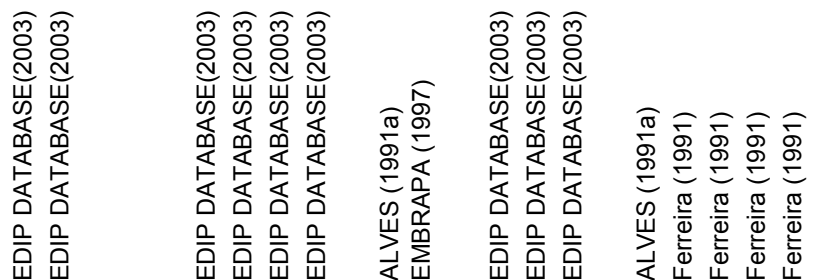

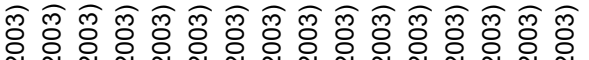

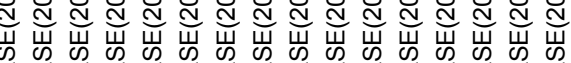

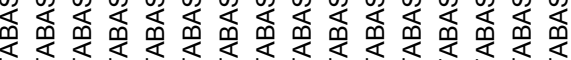

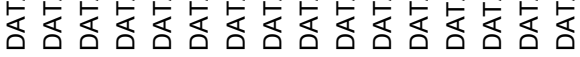

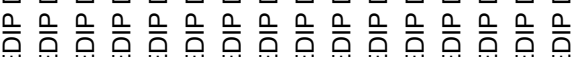

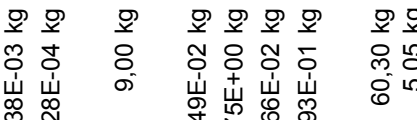

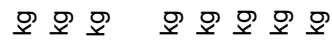

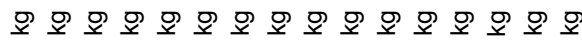
ㅇํำ

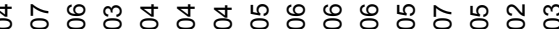

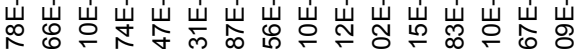
峞岩

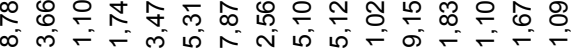
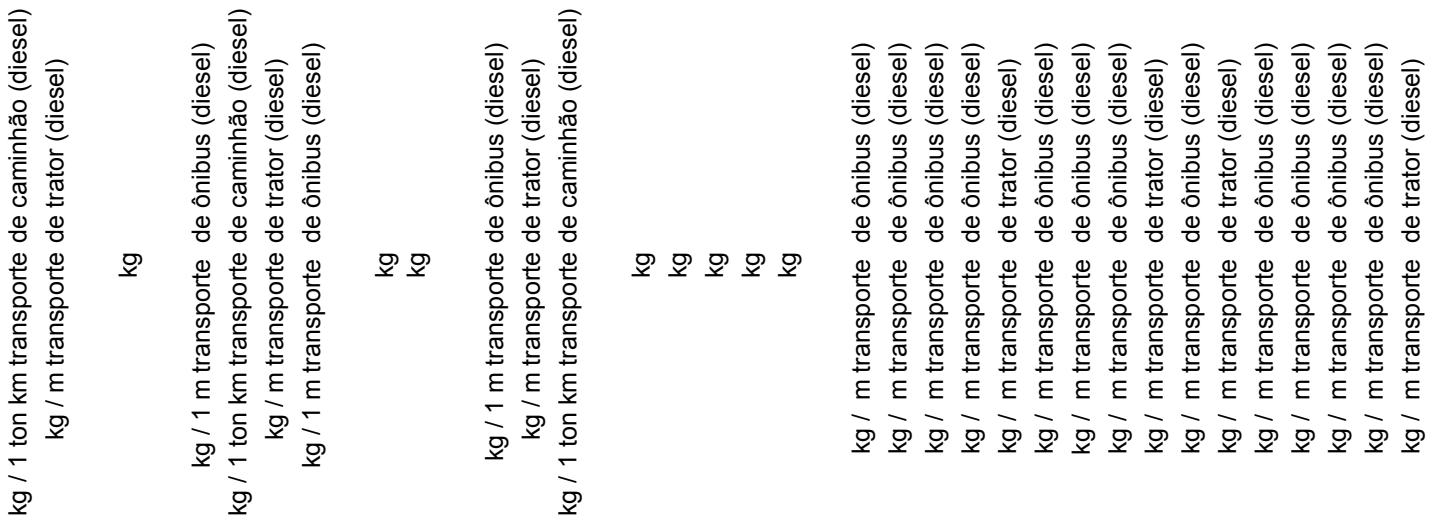

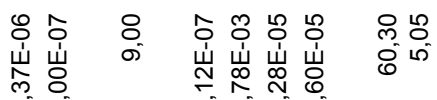

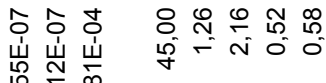

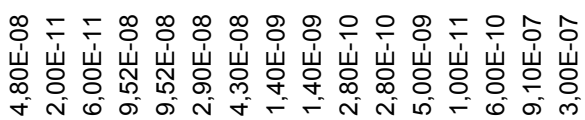

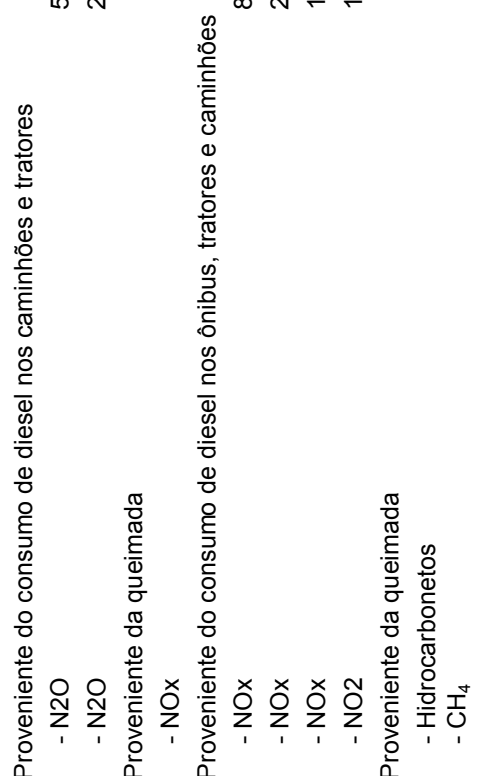

\& के 


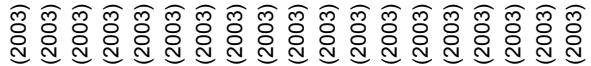

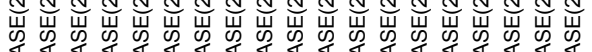

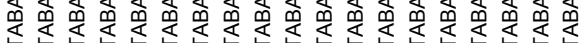

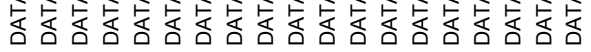

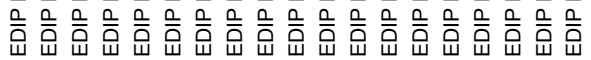

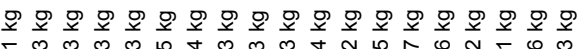

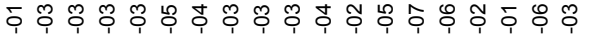

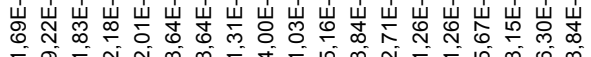

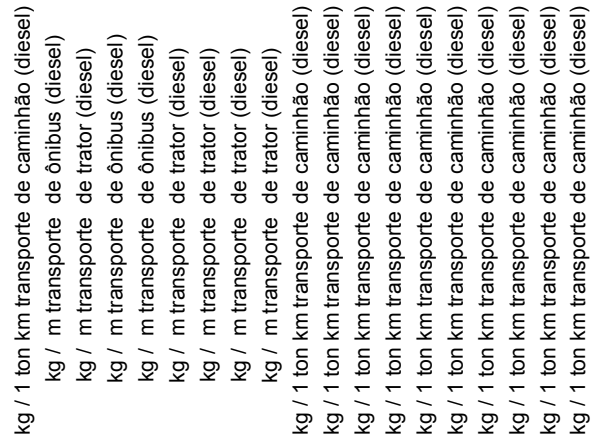

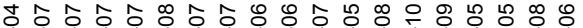

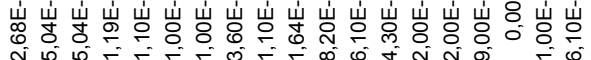

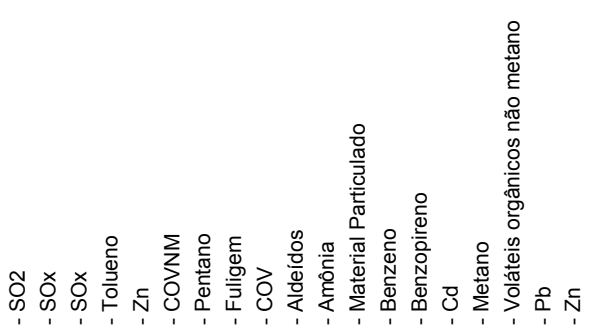

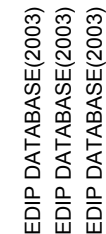

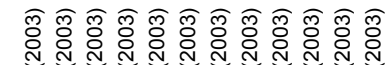

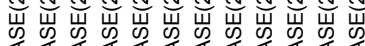

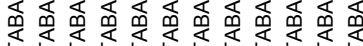

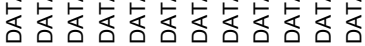

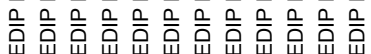

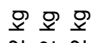

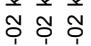

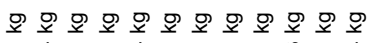

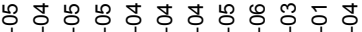
峞 崖
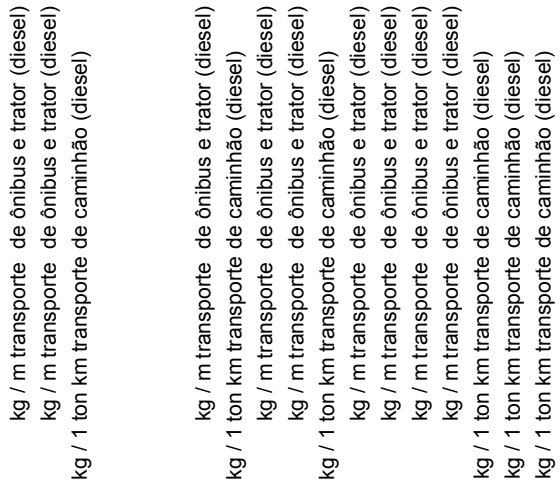

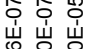
嵌 岁

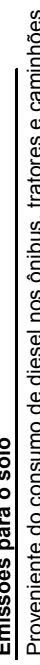

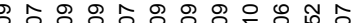

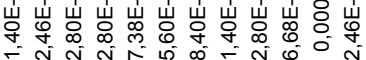




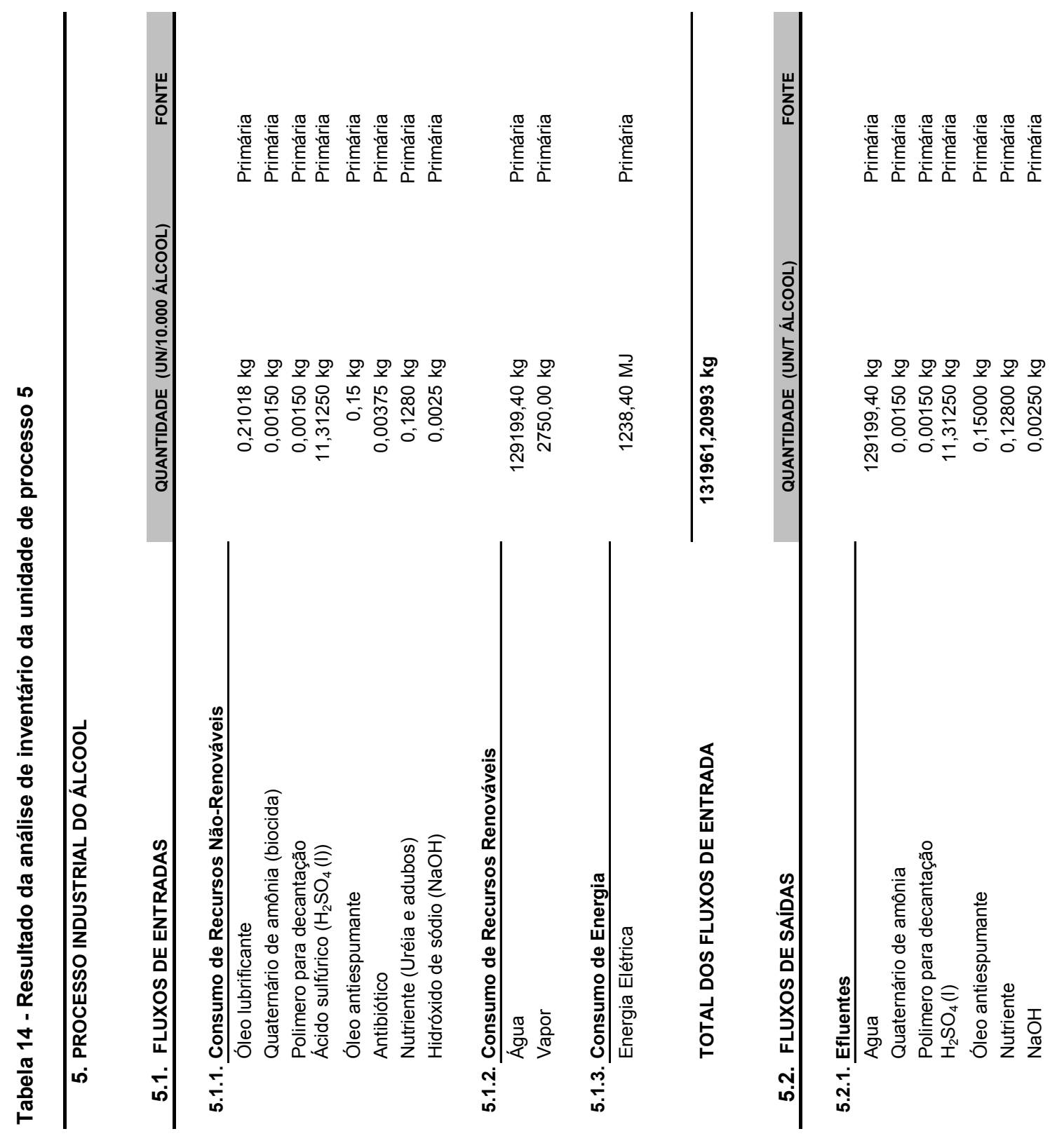




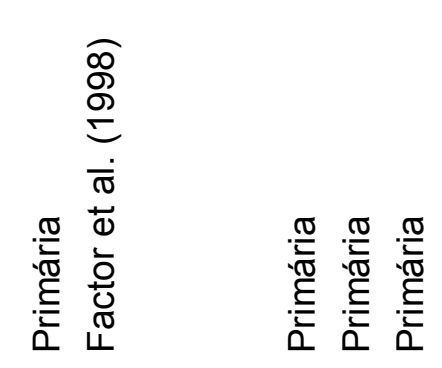

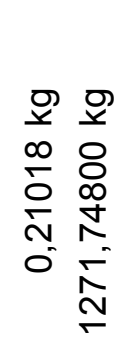
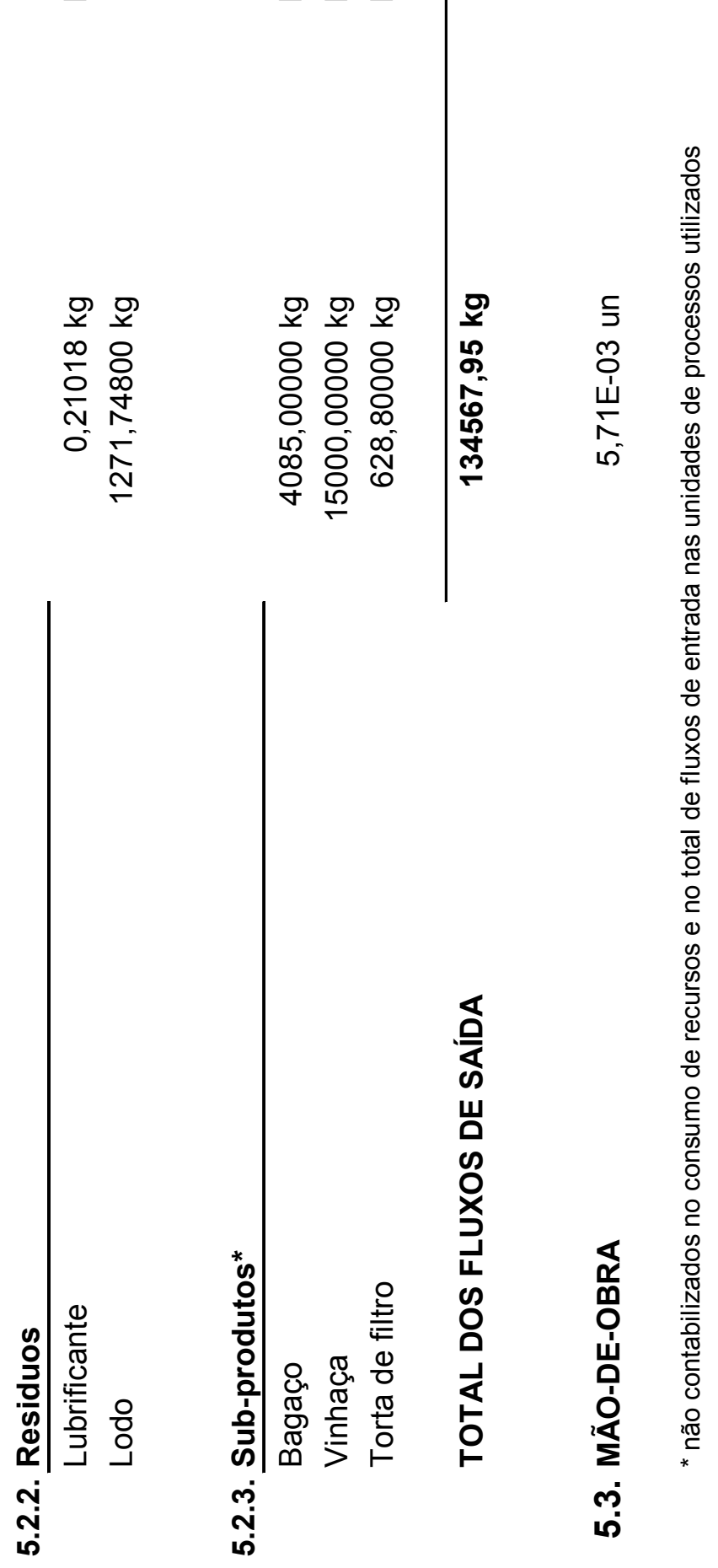


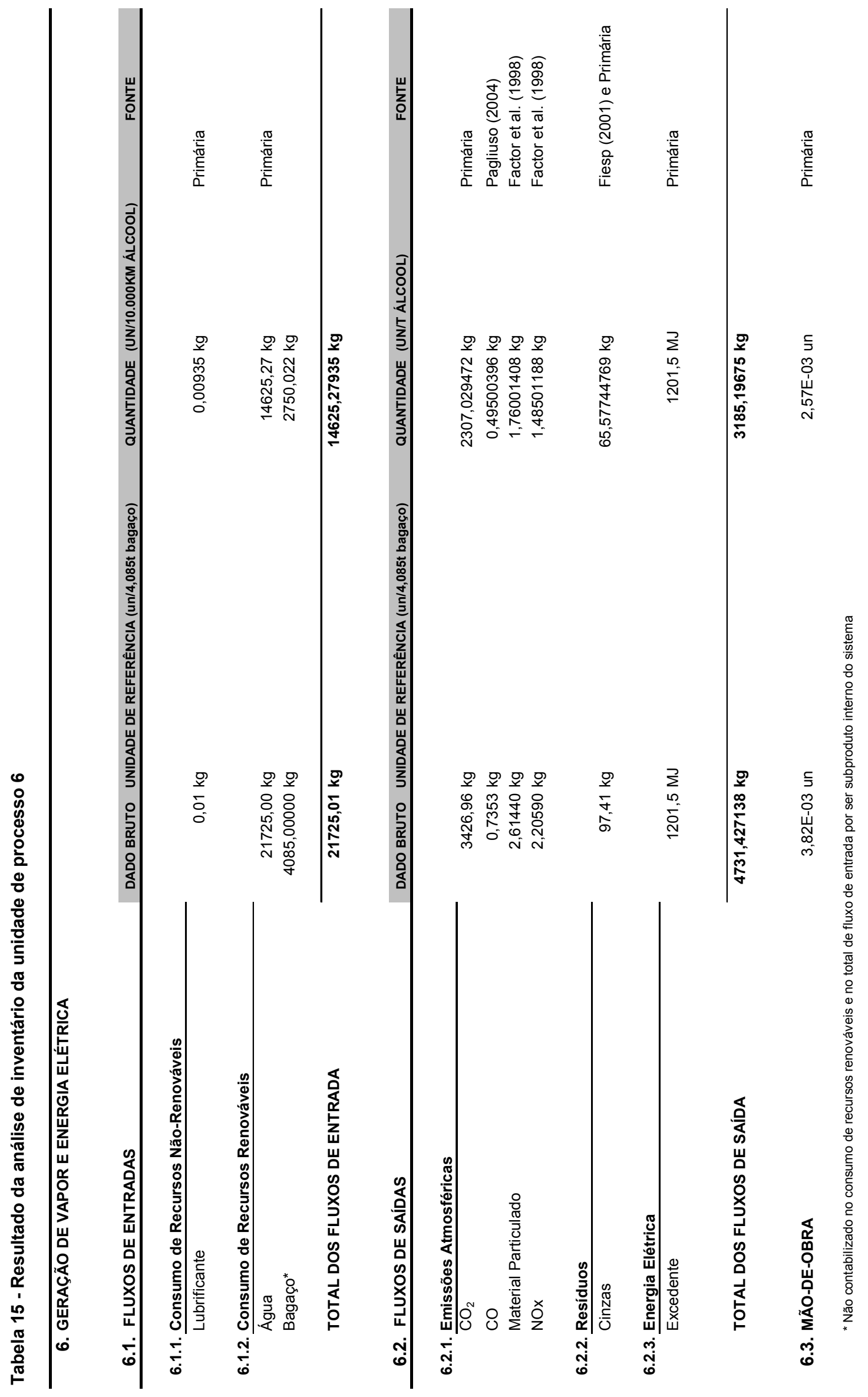




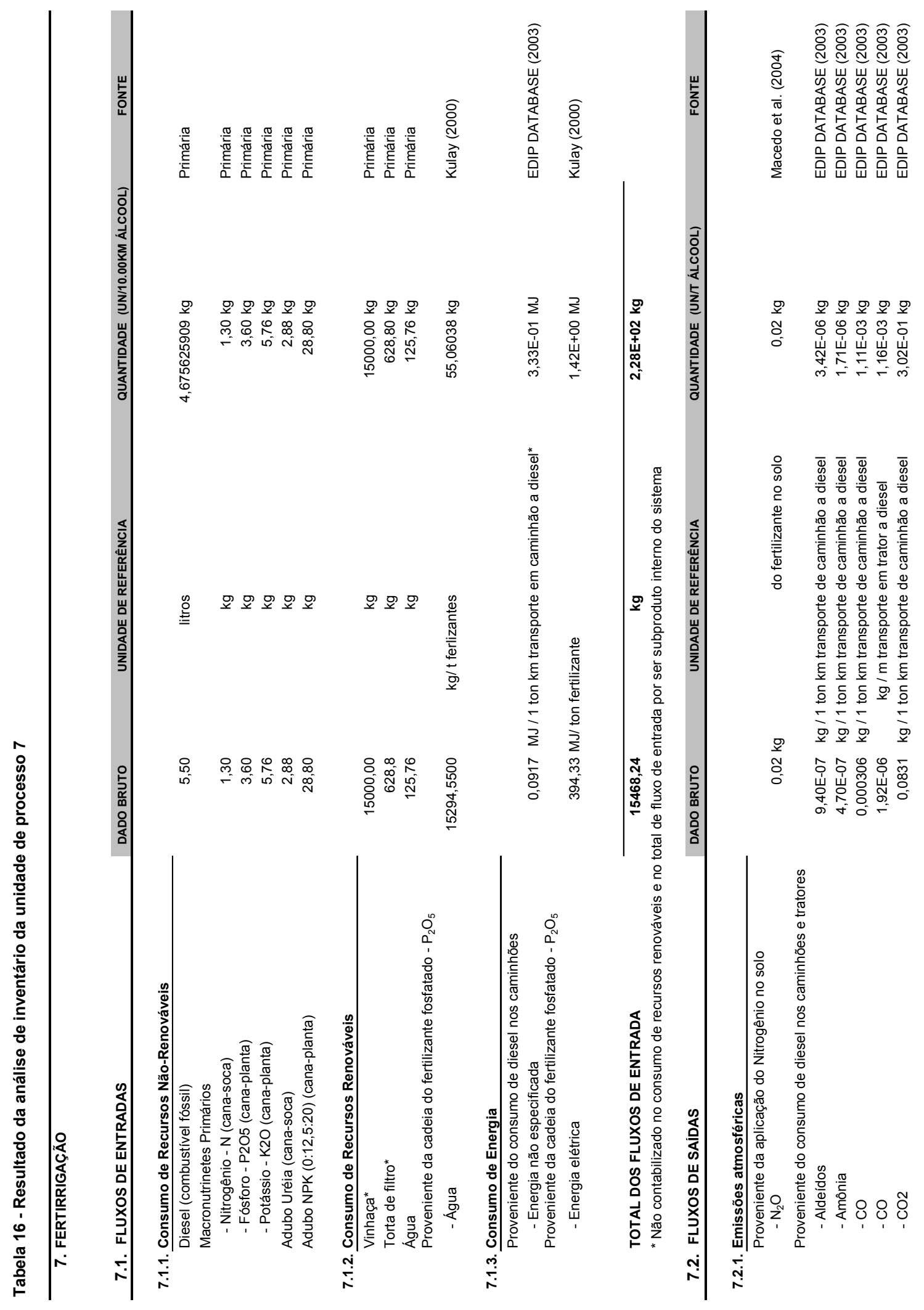




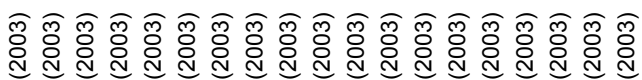

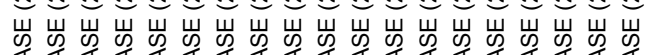

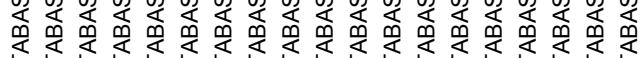

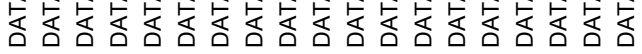

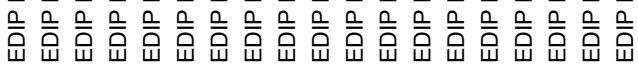

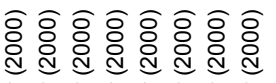

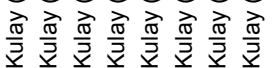

訚商

岗荝岗

要变旁

廷客喜

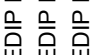

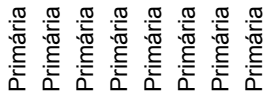

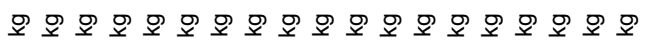

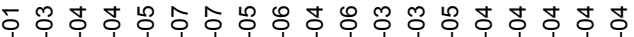

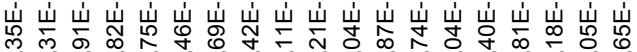

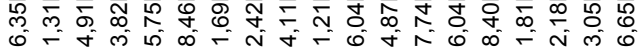

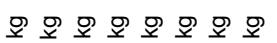

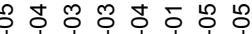
岂岂岁岁岕岁岁岁 Ninc

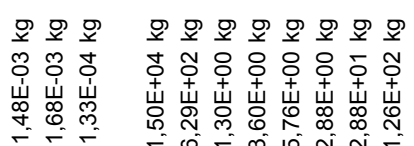

กิ

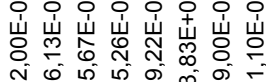

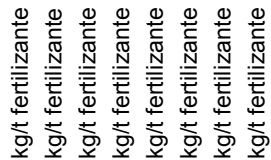

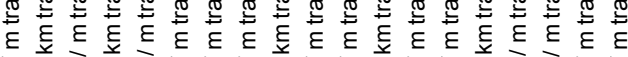

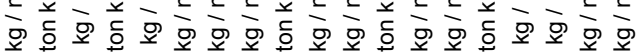

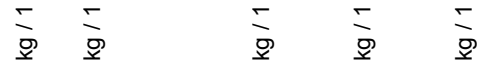

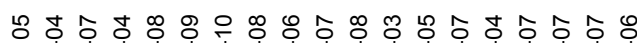

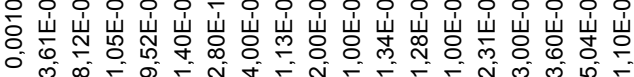

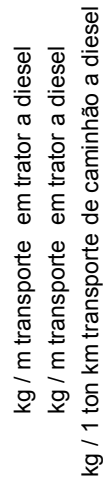

오모오오오오오오

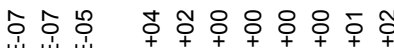

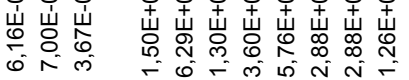

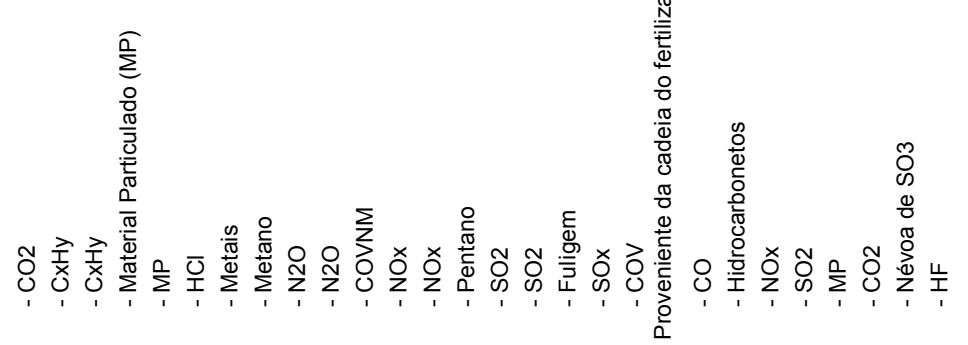

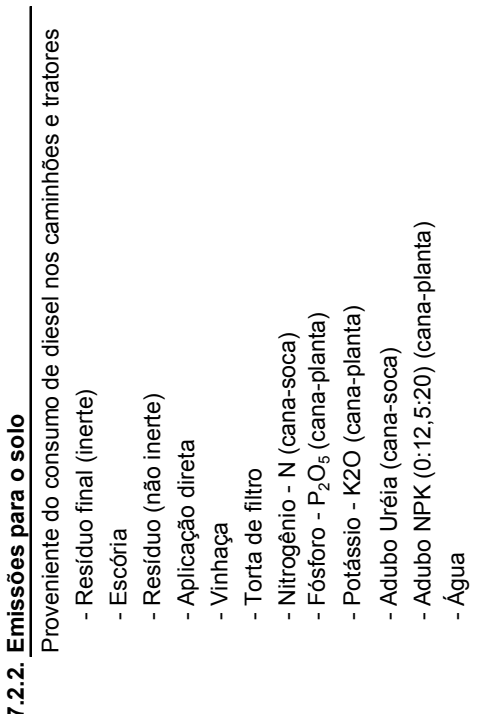




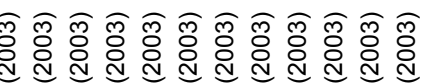

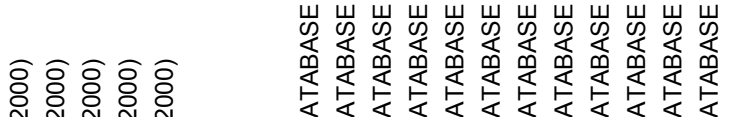

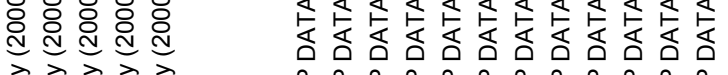

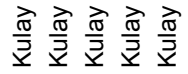

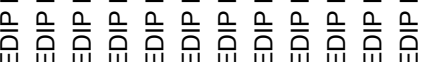

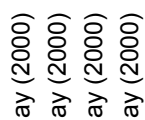

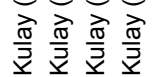

$\sum_{\substack{\frac{\pi}{6} \\ \frac{\cos }{2}}}^{\frac{\pi}{2}}$

모 모 모 무 무

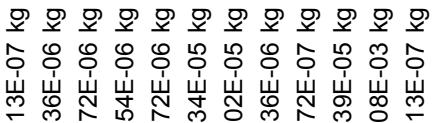

무 무 무

웅유 융

嵌㞧

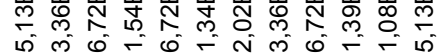

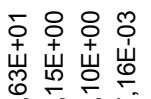

IIII
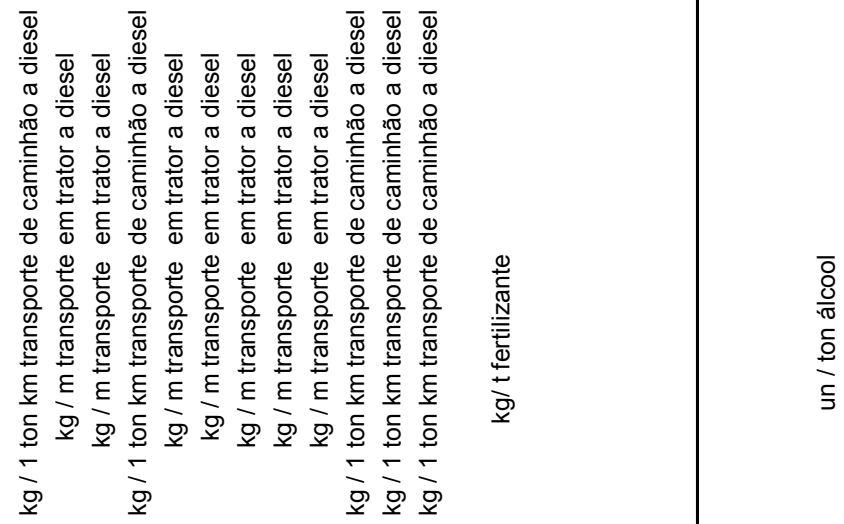

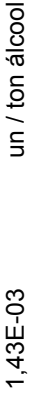

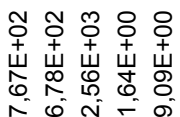

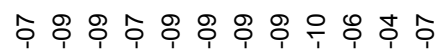

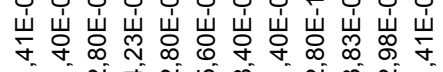

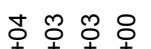

怘怘怘怘
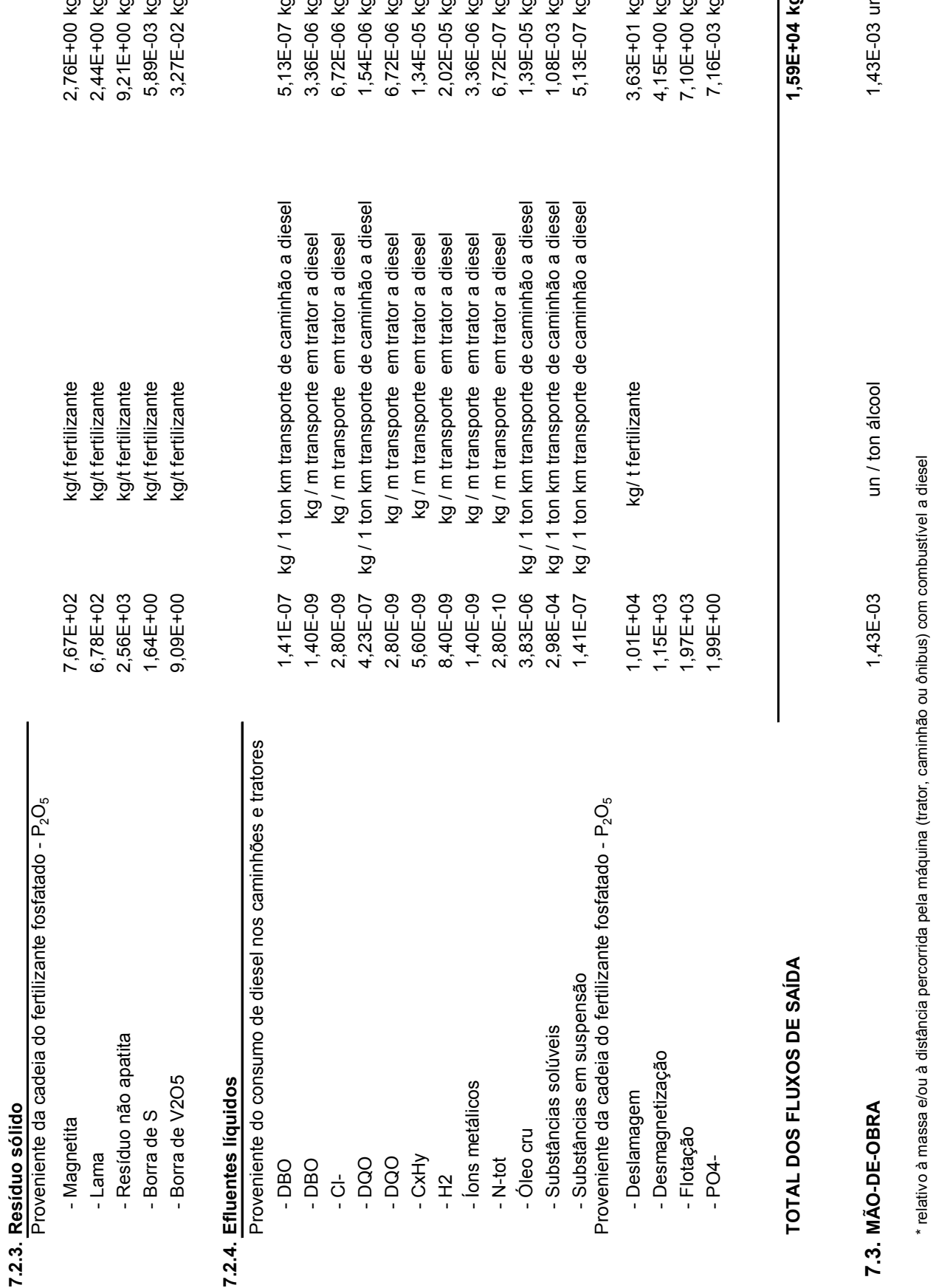


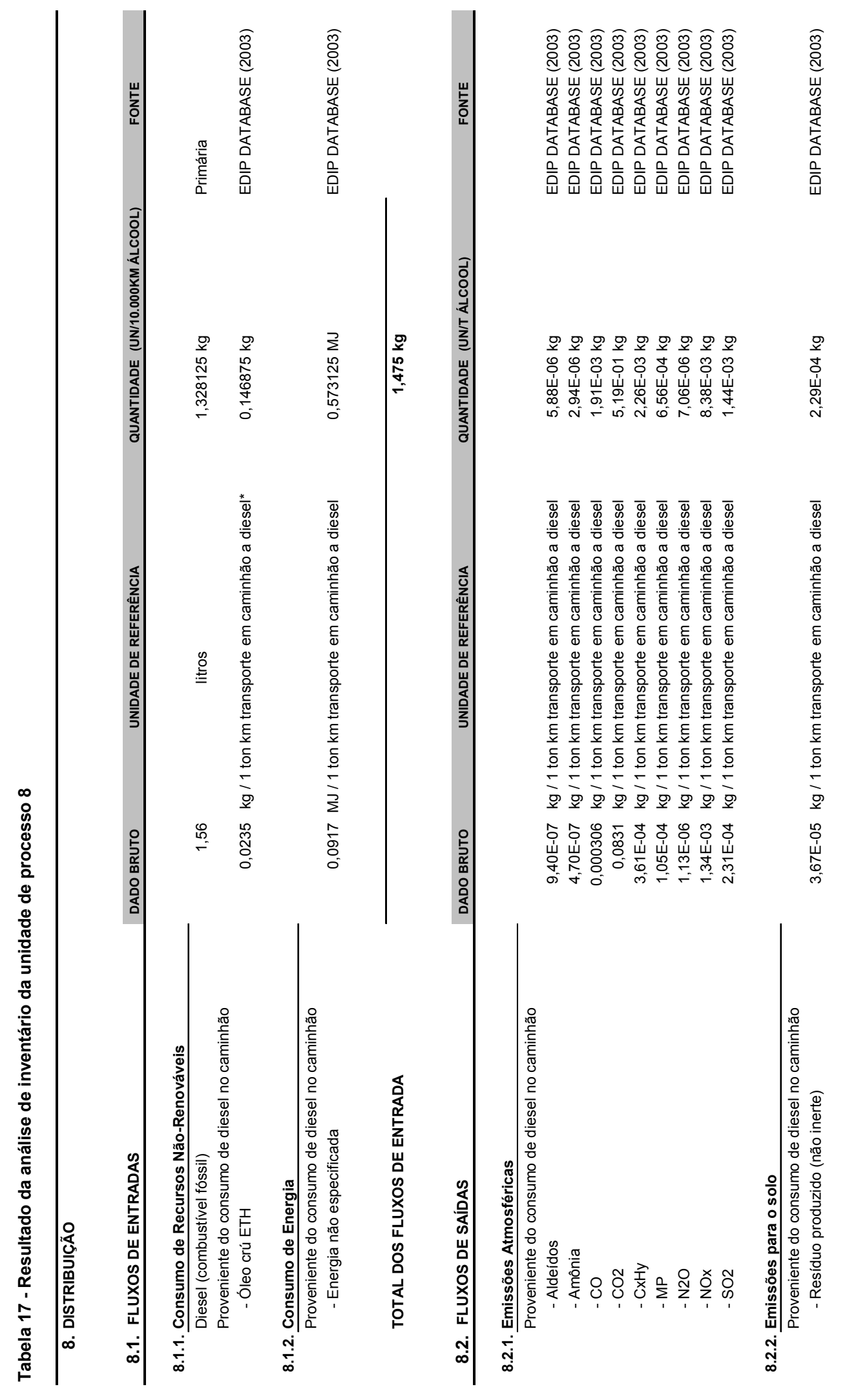




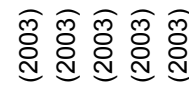

菢嵌嵌嵌

产高要要要

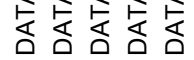

言产产㖕高

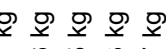

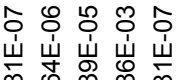

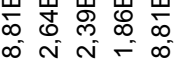

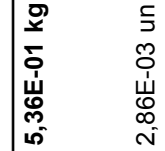

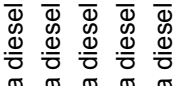

孚

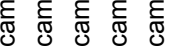

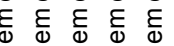

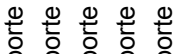

0
0
0

至至咅咅吉

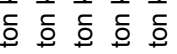

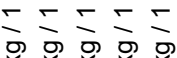

ㅇํㅇ웡

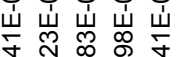

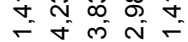

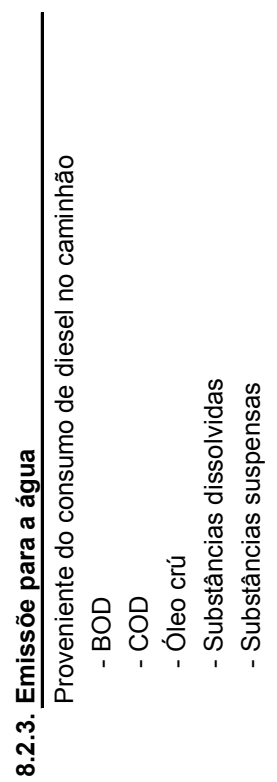




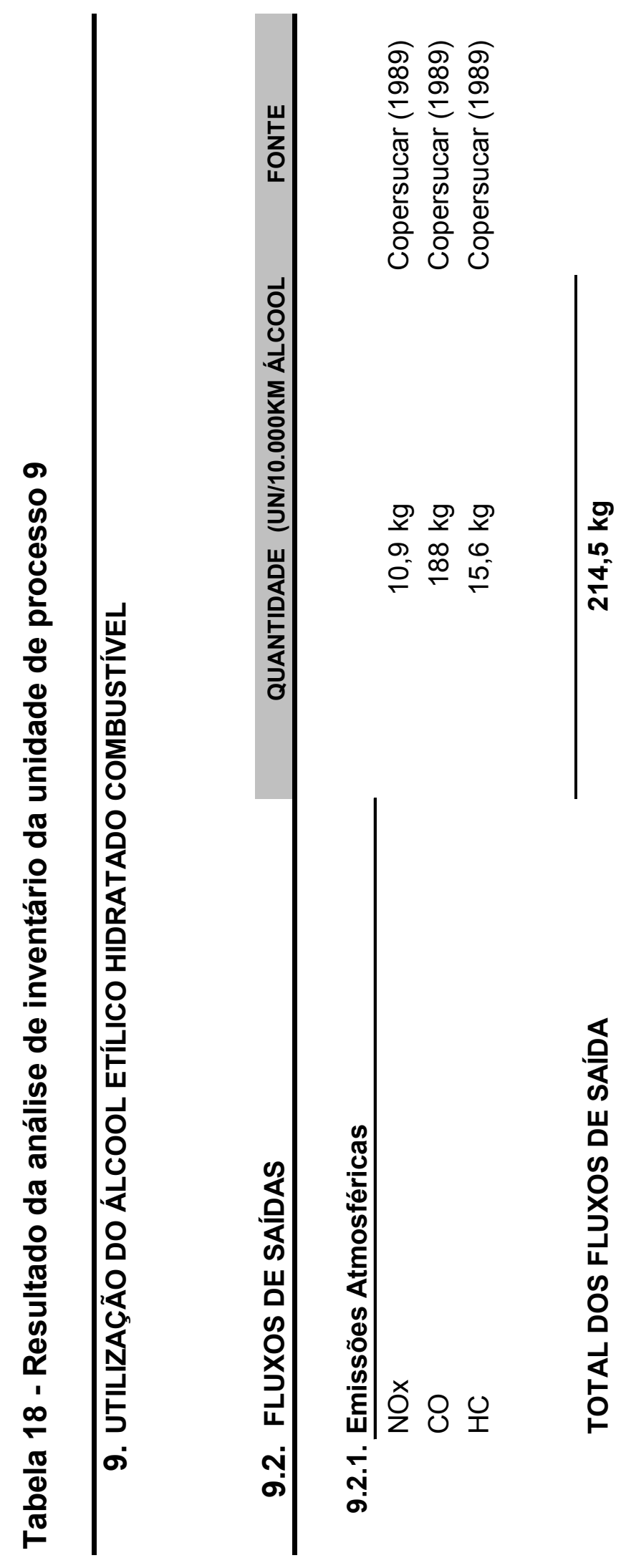


Especificamente com relação às emissões atmosféricas, cujos resultados são utilizados pelo método EDIP e pela Exergia, os resultados são apresentados a seguir.

As maiores quantidades de emissões atmosféricas, referentes ao ciclo de vida do álcool etílico hidratado combustível, incluindo o $\mathrm{CO}_{2}$ emitido pela queimada (atividade 4) e pela geração de vapor e de energia elétrica (atividade 7), que são utilizadas pela avaliação exergética, estão apresentadas na tabela 19, com base no fluxo de referência.

Tabela 19 - Quantidade de substâncias atmosféricas emitidas $\left(Q_{\mathrm{e}}\right)$ por tonelada de álcool, incluído o $\mathrm{CO}_{2}$ emitido pela queimada e pela geração de vapor e de energia elétrica

\begin{tabular}{|c|c|c|c|c|c|c|c|c|c|}
\hline $\begin{array}{c}\text { Emissões } \\
\text { Atmosf. }\end{array}$ & Ativ. 1 & Ativ. 2 & Ativ. 3 & Ativ. 4 & Ativ. 6 & Ativ. 7 & Ativ. 8 & Ativ. 9 & Total \\
\hline & $(\mathrm{kg} / \mathrm{t}$ & $(\mathrm{kg} / \mathrm{t}$ & $(\mathrm{kg} / \mathrm{t}$ & $(\mathrm{kg} / \mathrm{t}$ & $(\mathrm{kg} / \mathrm{t}$ & $(\mathrm{kg} / \mathrm{t}$ & $(\mathrm{kg} / \mathrm{t}$ & $(\mathrm{kg} / \mathrm{t}$ & $(\mathrm{kg} / \mathrm{t}$ \\
\hline & álcool) & álcool) & álcool) & álcool) & álcool) & álcool) & álcool) & álcool) & álcool) \\
\hline $\mathrm{CO}_{2}$ & 1,975 & 1,283 & 3,191 & $5.895,51$ & $2.307,03$ & 0,937 & 0,519 & 0 & $8.210,445$ \\
\hline NOx & 0,019 & 0,016 & 0,046 & 10,815 & 1,485 & 0,013 & 0,008 & 10,900 & 23,303 \\
\hline $\mathrm{CO}$ & 0,006 & 0,005 & 0,009 & 303,031 & 0,495 & 0,002 & 0,002 & 188,000 & 491,549 \\
\hline $\mathrm{SO}_{2}$ & 0,004 & 0,002 & 0,025 & 0,186 & 0 & 0,001 & 0,001 & 0 & 0,219 \\
\hline $\mathrm{HC}$ & 0,001 & 0,002 & 0,005 & 60,497 & 0 & 0,002 & 0,002 & 15,600 & 76,109 \\
\hline $\mathrm{NO}_{2}$ & 0 & 0,004 & 0 & 0,293 & 0 & 0 & 0 & 0 & 0,297 \\
\hline SOx & 0,001 & 0,0004 & 0,0005 & 0,011 & 0 & 0,0003 & 0 & 0 & 0,013 \\
\hline Tolueno & 0 & 0,00003 & 0 & 0,002 & 0 & 0 & 0 & 0 & 0,002 \\
\hline $\mathrm{N}_{2} \mathrm{O}$ & 0,0003 & 0,081 & 0,151 & 0,000 & 0 & 0,020 & 0,000007 & 0 & 0,252 \\
\hline K & 0 & 0 & 0 & 1,260 & 0 & 0 & 0 & 0 & 1,260 \\
\hline $\mathrm{Ca}$ & 0 & 0 & 0 & 2,160 & 0 & 0 & 0 & 0 & 2,160 \\
\hline $\mathrm{Mg}$ & 0 & 0 & 0 & 0,522 & 0 & 0 & 0 & 0 & 0,522 \\
\hline$S$ & 0 & 0 & 0 & 0,576 & 0 & 0 & 0 & 0 & 0,576 \\
\hline $\mathrm{CH}_{4}$ & 0,001 & 0,0003 & 0,001 & 5,106 & 0 & 0,00002 & 0 & 0 & 5,108 \\
\hline Total & 2,007 & 1,393 & 3,429 & $6.279,97$ & $2.309,01$ & 0,974 & 0,533 & 214,500 & $8.811,816$ \\
\hline
\end{tabular}

De acordo com a tabela 19, a atividade 4 (colheita de cana-de-açúcar) é a atividade de maior emissão atmosférica do ciclo de vida do álcool. A 
contribuição dos gases mais emitidos durante o ciclo de vida do álcool está representada no gráfico 1 e apresentada na tabela 20 . A grande quantidade de $\mathrm{CO}_{2}, \mathrm{CO}$ e hidrocarbonetos deve-se à utilização intensa de diesel nas máquinas agrícolas, nos caminhões e nos ônibus, além das emissões na queimada de cana e na queima do bagaço na caldeira.

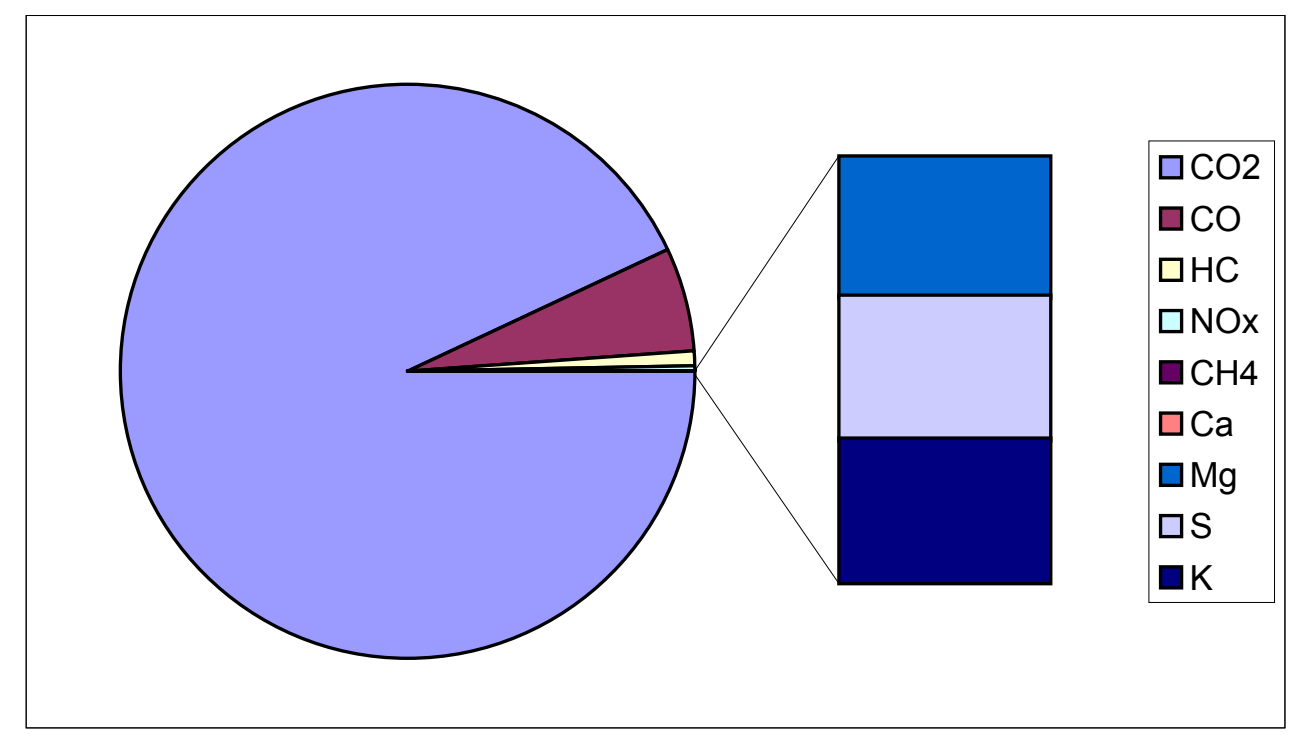

Gráfico 1 - Maiores emissões atmosféricas do ciclo de vida do álcool

Tabela 20: Porcentagem das maiores emissões atmosféricas do ciclo de vida do álcool considerando o $\mathrm{CO}_{2}$ da queimada e do uso do bagaço

\begin{tabular}{cc}
\hline Substância emitida & Porcentagem (\%) \\
\hline $\mathrm{CO}_{2}$ & 93,18 \\
$\mathrm{CO}$ & 5,58 \\
$\mathrm{HC}$ & 0,86 \\
$\mathrm{NOx}$ & 0,26 \\
$\mathrm{CH}_{4}$ & 0,06 \\
$\mathrm{Ca}$ & 0,02 \\
$\mathrm{Mg}$ & 0,01 \\
$\mathrm{~S}$ & 0,01 \\
$\mathrm{~K}$ & 0,01 \\
\hline
\end{tabular}


Desconsiderando a quantidade de $\mathrm{CO}_{2}$ emitida durante a queimada $(5.782,27 \mathrm{~kg})$ e durante a combustão do bagaço $(2.307,029 \mathrm{~kg})$, assim como durante a fermentação do caldo e uso do álcool devido à consideração da absorção do $\mathrm{CO}_{2}$ durante o crescimento da cana-de-açúcar, o dado da quantidade de $\mathrm{CO}_{2}$ a ser utilizado pelo método EDIP na avaliação do potencial de aquecimento global é de 121,146 kg. Dessa forma, como mostram o gráfico 2 e tabela 21 , o CO é a substância mais emitida na atmosfera durante o ciclo de vida do álcool, com 68,03\%.

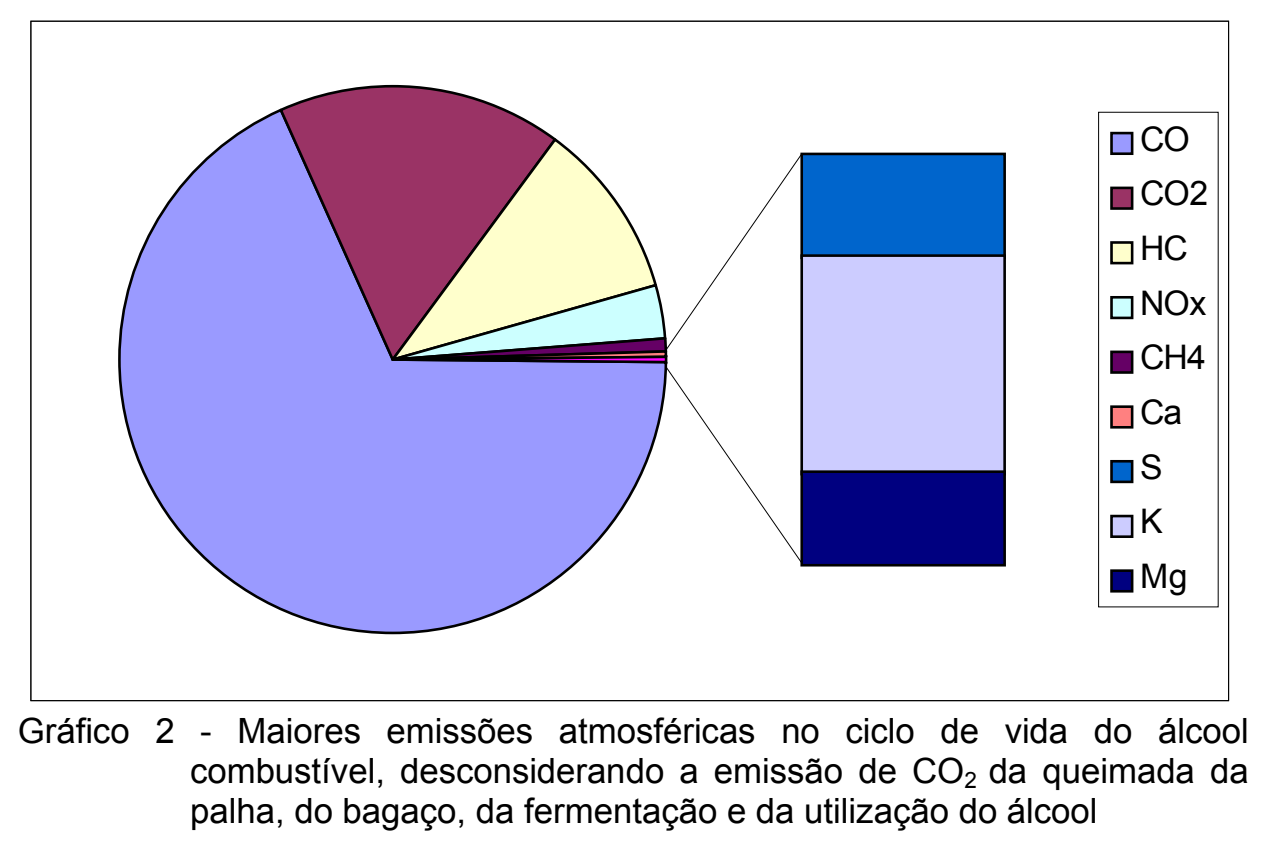

Tabela 21: Porcentagem das maiores emissões atmosféricas do ciclo de vida do álcool, desconsiderado a emissão de $\mathrm{CO}_{2}$ da queimada da palha, do bagaço, da fermentação e da utilização do álcool

\begin{tabular}{cc}
\hline Substância emitida & Porcentagem (\%) \\
\hline $\mathrm{CO}$ & 68,03 \\
$\mathrm{CO}_{2}$ & 16,77 \\
$\mathrm{HC}$ & 10,53 \\
$\mathrm{NOx}$ & 3,23 \\
$\mathrm{CH}_{4}$ & 0,71 \\
$\mathrm{Ca}$ & 0,30 \\
$\mathrm{~S}$ & 0,08 \\
$\mathrm{~K}$ & 0,17 \\
$\mathrm{Mg}$ & 0,07 \\
\hline
\end{tabular}


Pelas tabelas 19, 20 e 21, verifica-se a grande quantidade de $\mathrm{CO}_{2}$ emitida, principalmente pela queimada, e absorvida durante o crescimento. Contudo, é importante destacar que tal absorção, segundo Ometto, A. (2000), é realizada durante um ano ou um ano e meio, enquanto a emissão da queimada da palha da cana ocorre em alguns minutos e de forma difusa.

\subsection{Avaliação de impacto do ciclo de vida}

Para um estudo de ACV ser capaz de sustentar decisões e servir de base para respostas em relação a determinadas questões ambientais, os dados do inventário precisam ser interpretados a fim de definir os potenciais impactos.

A interpretação deve ser realizada a partir de um bom conhecimento do sistema estudado, dos recursos e deve ser aplicada aos dados do inventário mais significativos e de alto potencial de alterações do meio.

\subsubsection{Avaliação de Impacto pelo método EDIP}

De acordo com Wenzel et al. (1997), avaliar ambientalmente um produto é, a partir da função produto, identificar e quantificar as mudanças ambientais causadas pelo seu ciclo de vida e relacionar esses impactos com o serviço do produto.

Assim, na avaliação de impacto, o resultado da análise de inventário é utilizado para se realizar a descrição dos potenciais impactos ambientais dos processos envolvidos no ciclo de vida. As seguintes categorias de potenciais impactos do método EDIP são consideradas, para cada unidade de processo do ciclo de vida do álcool etílico hidratado combustível:

- Consumo de recursos:

- Renováveis;

- Não-renováveis;

- Energia. 
- Potenciais de impactos ambientais:

- Potencial de aquecimento global;

- Potencial de formação fotoquímica de ozônio troposférico;

- Potencial de acidificação do meio;

- Potencial de eutrofização;

- Potencial de ecotoxicidade e

- Potencial de toxicidade humana.

Os resultados da avaliação de impacto do ciclo de vida do etanol hidratado combustível são descritos para cada unidade de processo.

\section{Consumo de recursos renováveis}

Como se observa na tabela 22 , as atividades de produção industrial do álcool (unidade de processo 5) e de geração de vapor e de energia elétrica (unidade de processo 6) são as maiores consumidoras de recursos naturais renováveis, por causa, principalmente, do alto consumo de água desses processos. A atividade 5 (produção industrial do álcool) apresenta a atividade de lavagem da cana como a de maior consumo de água.

Tabela 22 - Consumo de recursos renováveis

\begin{tabular}{cc}
\hline $\begin{array}{c}\text { Unidade de } \\
\text { processo }\end{array}$ & $\begin{array}{c}\text { Consumo de Recursos Renováveis } \\
(\mathrm{kg} / \mathrm{t} \text { álcool ou 10.000km álcool })\end{array}$ \\
\hline 1 & 8482,92 \\
2 & 697,74 \\
3 & 5706,4 \\
4 & 1,29 \\
5 & $131.949,40$ \\
6 & $14.625,27$ \\
7 & 180,82 \\
8 & 0 \\
9 & 0 \\
Total & $161.643,84$ \\
\hline
\end{tabular}




\section{Consumo de recursos não-renováveis}

De acordo com a tabela 23, observa-se que as maiores consumidoras de recursos não-renováveis são as atividades de tratos culturais (unidade de processo 3 ), de preparo do solo (unidade de processo 1) e de colheita de cana (unidade de processo 4), devido ao alto uso de agroquímicos e do consumo de diesel nas máquinas agrícolas, nos caminhões e nos ônibus.

Tabela 23 - Consumo de recursos não-renováveis

\begin{tabular}{cc}
\hline $\begin{array}{c}\text { Unidade de } \\
\text { processo }\end{array}$ & $\begin{array}{c}\text { Consumo de recursos não-renováveis } \\
(\mathrm{kg} / \mathrm{t} \text { álcool ou } 10.000 \mathrm{~km} \text { álcool })\end{array}$ \\
\hline 1 & 100,77 \\
2 & 18,88 \\
3 & 151,97 \\
4 & 63,91 \\
5 & 11,81 \\
6 & 0,01 \\
7 & 47,02 \\
8 & 1,475 \\
9 & 0 \\
Total & 395,83 \\
\hline
\end{tabular}

\section{Consumo de energia}

De acordo com a tabela 24 , a atividade de produção industrial do álcool (unidade de processo 5) é a maior consumidora de energia elétrica; contudo a geração de energia na atividade 6 supre essa demanda, com um excedente em todo o ciclo.

Este resultado não considera a perda de energia pela queimada e pelas demais emissões atmosféricas. Com o resultado da avaliação exergética com relação a tais emissões, pode se indicar o balanço do ciclo de vida do álcool, considerando-se a energia disponível no álcool, o excedente de energia e as perdas para a atmosfera. Esse balanço é realizado nos resultados da avaliação de impacto e da valoração pela Exergia. 
Tabela 24 - Consumo de energia

\begin{tabular}{cc}
\hline $\begin{array}{c}\text { Unidade de } \\
\text { processo }\end{array}$ & $\begin{array}{c}\text { Consumo de energia } \\
\text { (MJ / t álcool ou 10.000 km álcool) }\end{array}$ \\
\hline 1 & 0,001 \\
2 & 1,11 \\
3 & 16,85 \\
4 & 100,75 \\
5 & 1238,40 \\
6 & $-2439,90$ \\
7 & 1,75 \\
8 & 0,57 \\
9 & 0 \\
Total & $-1080,47$ \\
\hline
\end{tabular}

\section{Potencial de aquecimento global}

Como apresentado na tabela 25 , a atividade 4 , colheita de cana-deaçúcar, é a atividade de maior potencial para o efeito estufa, devido, principalmente, aos gases hidrocarbonetos, metano e monóxido de carbono, emitidos durante a queimada, e ao dióxido de carbono $\left(\mathrm{CO}_{2}\right)$, emitido pelo uso de diesel nos equipamentos agrícolas, nos ônibus e nos caminhões, visto que o $\mathrm{CO}_{2}$ emitido pela queimada não é contabilizado.

Tabela 25 - Potencial de aquecimento global

\begin{tabular}{cc}
\hline $\begin{array}{c}\text { Unidades de } \\
\text { processo }\end{array}$ & $\begin{array}{c}\text { Potencial de aquecimento global (kg } \\
\mathbf{C O}_{\mathbf{2}} \text { eq. / } \mathbf{t} \text { álcool ou } \mathbf{1 0 . 0 0 0 ~} \mathbf{k m} \text { álcool) }\end{array}$ \\
\hline 1 & 2,10 \\
2 & 27,09 \\
3 & 51,22 \\
4 & $1.029,40$ \\
5 & 0 \\
6 & 0,99 \\
7 & 7,21 \\
8 & 0,53 \\
9 & 422,80 \\
Total & $1.541,34$ \\
\hline
\end{tabular}




\section{Potencial de formação de ozônio troposférico}

De acordo com a tabela 26, a atividade de maior potencial para a formação de ozônio é a atividade 4 (colheita de cana). Isso se deve, principalmente, aos hidrocarbonetos e ao monóxido de carbono emitidos durante a queimada da cana.

Tabela 26 - Potencial de formação de ozônio troposférico

\begin{tabular}{cc}
\hline $\begin{array}{c}\text { Unidades de } \\
\text { processo }\end{array}$ & $\begin{array}{c}\text { Potencial de formação de ozônio }\left(\mathbf{k g ~ C}_{\mathbf{2}} \mathrm{H}_{\mathbf{4}} \text { eq. }\right. \\
\text { / } \mathbf{t} \text { álcool ou } \mathbf{1 0 . 0 0 0 ~ k m ~ a ́ l c o o l ) ~}\end{array}$ \\
\hline 1 & 0,001 \\
2 & 0,002 \\
3 & 0,004 \\
4 & 42,547 \\
5 & 0 \\
6 & 0,020 \\
7 & 0,001 \\
8 & 0,001 \\
9 & 15,320 \\
Total & 57,896
\end{tabular}

\section{Potencial de acidificação}

De acordo com a tabela 27, a atividade 4 (colheita de cana) é a de maior potencial de impacto para a acidificação. Isso se deve, principalmente, aos óxidos de nitrogênio (NOx) emitidos durante a queimada da cana.

Tabela 27 - Potencial de acidificação

\begin{tabular}{cc}
\hline Unidades de processo & $\begin{array}{c}\text { Potencial de acidificação } \\
\left(\mathrm{kg} \mathrm{SO}_{2} \text { eq. / } \mathrm{t} \text { álcool ou } 10.000 \mathrm{~km} \text { álcool }\right)\end{array}$ \\
\hline 1 & 0,02 \\
2 & 0,01 \\
3 & 0,06 \\
4 & 7,97 \\
5 & 0 \\
6 & 1,04 \\
7 & 0,01 \\
8 & 0,01 \\
9 & 7,63 \\
Total & 16,75 \\
\hline
\end{tabular}




\section{Potencial de eutrofização}

Pela tabela 28, observa-se que as atividades que mais podem contribuir para a eutrofização são as atividades que incorporam nutrientes ao solo, as atividades 3 (tratos culturais), 7 (fertirrigação) e 2 (plantio).

Tabela 28 - Potencial de eutrofização

\begin{tabular}{|c|c|c|c|}
\hline & \multicolumn{3}{|c|}{ Potencial de eutrofização } \\
\hline & Nitrogênio & Fósforo & Sinergia do $\mathrm{N}$ e $\mathrm{P}$ \\
\hline Unidades de & ( $\mathrm{kg} \mathrm{N} / \mathrm{t}$ álcool ou 10.000 & (kg P / t álcool ou 10.000 & $\left(\mathrm{~kg} \mathrm{NO}_{3}^{-}\right.$eq. / $\mathrm{t}$ álcool ou \\
\hline processo & km álcool) & km álcool) & 10.000 km álcool) \\
\hline 1 & 0,006 & 0,00 & 0,02700 \\
\hline 2 & 5,376 & 1,68 & 77,73316 \\
\hline 3 & 10,088 & 40,40 & $1.338,70880$ \\
\hline 4 & 0,004 & 0,00 & 0,00003 \\
\hline 5 & 0,128 & 0,00 & 0,56704 \\
\hline 6 & 0,446 & 0,00 & 2,00477 \\
\hline 7 & 5,496 & 4,95 & 182,89578 \\
\hline 8 & 0 & 0 & 0 \\
\hline 9 & 0 & 0 & 0 \\
\hline Total & 21,543 & 47,03 & $1.601,93658$ \\
\hline
\end{tabular}

\section{f) Potencial de ecotoxicidade}

De acordo com a tabela 29, a ecotoxicidade hídrica pode ser causada, principalmente, pelas atividades 1 (preparo do solo) e 3 (tratos culturais), devido ao uso intensivo de agrotóxicos no solo, que apresentam a possibilidade de percolação ou lixiviação para os recursos hídricos.

A ecotoxicidade crônica do solo pode ser causada, principalmente, pelas atividades 3 (tratos culturais), 2 (plantio da cana-de-açúcar) e 1 (preparo do solo), devido ao uso intensivo de agrotóxicos aplicados diretamente no solo. 
Tabela 29 - Potencial de ecotoxicidade

\begin{tabular}{cccc}
\hline \multirow{2}{*}{$\begin{array}{c}\text { Unidades de } \\
\text { processo }\end{array}$} & $\begin{array}{c}\text { Crônica na água } \\
\left(\mathrm{m}^{3} \text { água / } \mathrm{t} \text { álcool ou }\right. \\
10.000 \mathrm{~km} \text { álcool })\end{array}$ & $\begin{array}{c}\text { Aguda na água } \\
\left(\mathrm{m}^{3} \text { água } / \mathrm{t} \text { álcool ou }\right. \\
10.000 \mathrm{~km} \text { álcool })\end{array}$ & $\begin{array}{c}\text { Crônica no solo } \\
\left(\mathrm{m}^{3} \text { solo } / \mathrm{t} \text { álcool ou }\right. \\
10.000 \mathrm{~km} \text { álcool })\end{array}$ \\
1 & $1.286,73$ & 128,520 & $13.749,15$ \\
2 & 0,73 & 0,004 & $1.664 .131,50$ \\
3 & 772,34 & 77,112 & $5.589 .678,38$ \\
4 & 72,01 & 0 & 165,02 \\
5 & 0 & 0 & 0 \\
6 & 0 & 0 & 0 \\
7 & 0 & 0 & 0 \\
8 & 0 & 0 & 0 \\
9 & 0 & 0 & $7.267 .724,06$ \\
\hline
\end{tabular}

\section{g) Potencial de toxicidade humana}

A tabela 30 apresenta os resultados dos potenciais de toxicidade humana das atividades do ciclo de vida do álcool, sendo a via aérea a de maior contribuição, devido, principalmente, à atividade 4 (colheita de cana), pelos gases tóxicos emitidos na queimada de cana, incluindo o material particulado emitido, e pelo uso de diesel nos caminhões, nas máquinas agrícolas e nos ônibus.

Tabela 30 - Potencial de toxicidade humana

\begin{tabular}{cccc}
\hline \multirow{2}{*}{$\begin{array}{c}\text { Unidades de } \\
\text { processo }\end{array}$} & $\begin{array}{c}\text { Via aérea } \\
\left(\mathrm{m}^{3} \mathrm{ar} / \mathrm{t} \text { álcool ou }\right. \\
10.000 \mathrm{~km} \text { álcool })\end{array}$ & $\begin{array}{c}\text { Via hídrica } \\
\left(\mathrm{m}^{3} \text { água } / \mathrm{t} \text { álcool ou }\right. \\
10.000 \mathrm{~km} \text { álcool })\end{array}$ & $\begin{array}{c}\text { Via terrestre } \\
\left(\mathrm{m}^{3} \text { solo } / \mathrm{t} \text { álcool ou }\right. \\
10.000 \mathrm{~km} \text { álcool })\end{array}$ \\
1 & $165.616,65$ & 0,70 & 0,0064 \\
2 & $459.260,26$ & 0,22 & 0,0007 \\
3 & $459.769,30$ & 0,58 & 0,0165 \\
4 & $1.258 .456 .278,73$ & 27,35 & 12,7625 \\
5 & 0 & 0 & 0 \\
6 & $71.869 .039,00$ & 0 & 0 \\
7 & $124.772,57$ & 0 & 0 \\
8 & $88.614,25$ & 0 & 0 \\
9 & $249.780 .000,00$ & 0 & 12,7862 \\
\hline
\end{tabular}




\subsubsection{Avaliação de impacto e valoração ambiental pela Exergia}

A avaliação de impacto e a valoração ambiental realizadas pela Exergia são baseadas, para as substâncias emitidas, em sua parte química, e para a queimada, na físico-química, visto que, para estes elementos, são os componentes que mais influenciam em termos de dano ou de impacto ambiental.

Devido à composição da atmosfera ser praticamente constante, de acordo com Szargut et al. (1988), para as substâncias emitidas, são utilizados os valores das Exergias químicas-padrão das substâncias atmosféricas de referências. Tais valores podem ser utilizados em avaliações exergéticas amplas, independentemente do local.

A avaliação e a valoração da queimada são realizadas com base na Exergia do combustível, palha da cana-de-açúcar, que incorpora, além da Exergia química, a Exergia física (termal).

Desse modo, busca-se quantificar as perdas exergéticas das emissões atmosféricas do ciclo de vida do álcool combustível, indicando a perda do trabalho útil mecânico (Exergia) ocorrido com as emissões (incluindo as queimadas) e o valor de seu impacto físico-químico direto. Analogamente, avalia-se e valora-se também, tendo como referência o meio ambiente, o trabalho absorvido pelo meio, a fim de equilibrar a concentração das substâncias emitidas para o ambiente-padrão.

Os resultados das perdas das Exergias químicas das maiores quantidades de emissões atmosféricas do ciclo de vida de uma tonelada de álcool combustível, incluindo a emissão de $\mathrm{CO}_{2}$ da queimada e do bagaço, são apresentados na tabela 31. Tais resultados são derivados dos resultados da tabela 19, da tabela 3 e das aplicações das eqs. (11), (12) e (13). 
Tabela 31 - Perdas exergéticas pelas substâncias atmosféricas emitidas no ciclo de vida do álcool etílico hidratado combustível

\begin{tabular}{|c|c|c|c|c|c|c|c|c|c|c|}
\hline & Ativ. 1 & Ativ. 2 & Ativ. 3 & Ativ. 4 & Ativ. 6 & Ativ. 7 & Ativ. 8 & Ativ. 9 & Total & $\%$ Total \\
\hline & $(\mathrm{kJ} / \mathrm{t}$ & $(\mathrm{kJ} / \mathrm{t}$ & $(\mathrm{kJ} / \mathrm{t}$ & $(\mathrm{kJ} / \mathrm{t}$ & $(\mathrm{kJ} / \mathrm{t}$ & $(\mathrm{kJ} / \mathrm{t}$ & $(\mathrm{kJ} / \mathrm{t}$ & $(\mathrm{kJ} / \mathrm{t}$ & $(\mathrm{kJ} / \mathrm{t}$ & $(\%)$ \\
\hline Subst. & álcool) & álcool) & álcool) & álcool) & álcool) & álcool) & álcool) & álcool) & álcool) & \\
\hline $\mathrm{CO}_{2}$ & 891,51 & 579,31 & $1.440,81$ & $2,66.10^{6}$ & $1,04.10^{6}$ & 422,91 & 234,493 & 0 & $3,71.10^{6}$ & 30,55 \\
\hline NOx & 57,67 & 47,02 & 136,57 & $3,20.10^{4}$ & $4,40.10^{3}$ & 37,35 & 24,813 & $3,23.10^{4}$ & $6,90.10^{4}$ & 0,6 \\
\hline $\mathrm{CO}$ & 60,82 & 46,97 & 85,47 & $2,98.10^{6}$ & $4,86.10^{3}$ & 22,32 & 18,783 & $1,85.10^{6}$ & $4,83.10^{6}$ & 40 \\
\hline $\mathrm{SO}_{2}$ & 17,84 & 9,90 & 121,56 & 912 & 0 & 4,99 & 7,063 & 0 & $1,07.10^{3}$ & 0,01 \\
\hline $\mathrm{HC}$ & 44,53 & 67,26 & 214,59 & $2,59.10^{6}$ & 0 & 77,31 & 96,741 & $6,69 \cdot 10^{5}$ & $3,26.10^{6}$ & 27 \\
\hline $\mathrm{NO}_{2}$ & 0 & 4,87 & 0 & 354 & 0 & 0 & 0 & 0 & 359 & 0,003 \\
\hline sox & 1,79 & 1,29 & 1,60 & 34,4 & 0 & 0,95 & 0 & 0 & 40 & 0,0003 \\
\hline Tolueno & 0 & 1,28 & 0 & 93,2 & 0 & 0 & 0 & 0 & 94,5 & 0,001 \\
\hline $\mathrm{N}_{2} \mathrm{O}$ & 0,64 & 196,16 & 367,51 & 0 & 0 & 47,52 & 0,017 & 0 & 612 & 0,005 \\
\hline $\mathrm{CH}_{4}$ & 43,70 & 14,14 & 53,06 & $2,65.10^{5}$ & 0 & 1,25 & 0 & 0 & $2,65.10^{5}$ & 2 \\
\hline Total & $1.118,50$ & 968,21 & $2.421,18$ & $8,53.10^{6}$ & $1,05.10^{6}$ & 614,61 & 381,910 & $2,55.10^{6}$ & $1,21.10^{7}$ & 100 \\
\hline$\%$ Total & 0,01 & 0,01 & 0,02 & 70,30 & 8,66 & 0,01 & 0,003 & 21,00 & 100 & \\
\hline
\end{tabular}

Pode-se observar, pela tabela 19, que as substâncias emitidas em maiores quantidades durante o ciclo de vida do álcool são, em ordem decrescente: $\mathrm{CO}_{2}$; $\mathrm{CO}$ e hidrocarbonetos. Contudo, de acordo com a tabela 31 , as maiores perdas de exergias relacionadas às emissões atmosféricas do ciclo de vida do álcool combustível são em ordem decrescente, das seguintes substâncias: $\mathrm{CO}, \mathrm{CO}_{2}$ e hidrocarbonetos. Isso mostra que o $\mathrm{CO}$ se apresenta no ambiente de referência-padrão em concentrações bem inferiores às do $\mathrm{CO}_{2}$. Desse modo, embora em quantidades emitidas menores, o trabalho para equilibrar o CO na concentração de referência do ambiente é superior.

De acordo com a tabela 31, a atividade de colheita de cana-de-açúcar é a atividade de maior perda exergética, com relação às emissões atmosféricas, por causa da queimada, do uso de combustíveis fósseis dos ônibus que transportam os trabalhadores do corte da cana, dos caminhões para o 
transporte da cana-de-açúcar e dos tratores. A quantidade total perdida de trabalho mecânico útil disponível pela unidade funcional é de $1.210 \mathrm{KJ}$.

A fim de se comparar a perda de Exergia das emissões com a Exergia do álcool, obteve-se, baseado em Ometto e Roma (2004), a Exergia química específica $\left(b_{c h}\right)$ do álcool pelas eqs. (10) e (11). A reação de formação do álcool etílico, a partir dos elementos químicos de referência-padrão é indicada a seguir:

$$
2 \mathrm{C} \text { (graf.) }+3 \mathrm{H}_{2}+1 / 2 \mathrm{O}_{2} \rightarrow \mathrm{C}_{2} \mathrm{H}_{5} \mathrm{OH}
$$

Seguindo as eqs. (10) e (11):

$b_{\text {ch } 22 \mathrm{H} 5 \mathrm{OH}}=\mathrm{E}_{\mathrm{f}} \mathrm{G}^{\circ}{ }_{\mathrm{C} 2 \mathrm{H} 5 \mathrm{OH}}+2 \cdot \mathrm{b}^{\circ}{ }_{\mathrm{ch} \mathrm{C}}$ (graf.) $+3 \cdot \mathrm{b}^{\circ}{ }_{\mathrm{ch} \mathrm{H} 2}+1 / 2 \cdot \mathrm{b}^{\circ}{ }_{\mathrm{ch} \mathrm{O} 2}$

Em Atkins (1994):

$\mathrm{E}_{\mathrm{f}} \mathrm{G}_{\mathrm{C} 2 \mathrm{H} 5 \mathrm{OH}}$ (energia livre de formação do álcool) = - 174,78 kJ/Mol;

MM (massa molecular) $\mathrm{C}_{2} \mathrm{H}_{5} \mathrm{OH}=46,07 \mathrm{~g} / \mathrm{Mol}$.

Em Szargut et al. (1988):

$\mathrm{b}^{\circ}{ }_{\mathrm{ch} \mathrm{C} \text { (graf.) }}=410,26 \mathrm{~kJ} / \mathrm{Mol}$;

$\mathrm{b}^{\circ}{ }_{\mathrm{ch} \mathrm{H} 2}=236,09 \mathrm{~kJ} / \mathrm{Mol}$;

$\mathrm{b}^{\circ}{ }_{\mathrm{ch} \mathrm{O} 2}=3,97 \mathrm{~kJ} / \mathrm{Mol}$

Portanto a Exergia química do etanol é:

$\mathrm{b}_{\mathrm{ch} \text { C2H5OH }}=1356 \mathrm{~kJ} / \mathrm{Mol}=29,43 \mathrm{~kJ} / \mathrm{g}$

Assim, para o fluxo de referência dos dados do ciclo de vida do álcool, a Exergia química do álcool $\left(\mathrm{B}_{\mathrm{C} 2 \mathrm{H} 5 \mathrm{OH}}\right)$ é igual a $29,43 \cdot 10^{6} \mathrm{~kJ}$.

Desse modo, durante o ciclo de vida do álcool, emitem-se, na atmosfera, $12,13.10^{6} \mathrm{~kJ} / \mathrm{t}$ álcool, representando uma perda das exergias químicas das emissões atmosféricas (sem contar a Exergia da queima da palha) de $41 \%$ com relação à do álcool.

Incluindo a queimada da cana-de-açúcar, é analisado o potencial total de trabalho útil físico e químico perdido pelas emissões atmosféricas, valor que pode ser considerado para a avaliação e a valoração ambiental do impacto físico-químico direto de tais emissões. 
Esse trabalho útil perdido com a prática da queimada pode ser calculado pelas eqs. (14) e (15), a partir da correlação para o cálculo exergético de combustíveis sólidos com umidade, dada em Szargut et al. (1988). Esse cálculo corresponde à Exergia física e química contida no combustível, no caso, na palha de cana-de-açúcar, calculada em Ometto et al. (2003b).

O elemento principal da palha é a celulose, cuja fórmula química é $\mathrm{C}_{6} \mathrm{H}_{10} \mathrm{O}_{5}$; portanto a fração mássica dos elementos são 0,44 de $\mathrm{C} ; 0,06$ de $\mathrm{H}_{2} \mathrm{e}$ 0,49 de $\mathrm{O}_{2}$. Os outros dados para o cálculo da Exergia específica da palha são: $\mathrm{PCl}=15.173,49 \mathrm{~kJ} / \mathrm{kg}$, segundo Lora et al. (2001) ; $\mathrm{h}_{\mathrm{a}}=2.442 \mathrm{~kJ} / \mathrm{kg}$, segundo Campo (1999); $Z_{a}=10 \%$, segundo Fiesp (2001); ex $=50$ kJ/kg, adotando-se $70 \%$ de umidade relativa do ar e temperatura ambiente, To $=25{ }^{\circ} \mathrm{C}$ e pressão a 1 atm, segundo Szargut et al. (1988).

O resultado da Exergia específica da palha é de $20.485,45 \mathrm{~kJ} / \mathrm{kg}$, o que indica que a palha é um ótimo combustível, melhor que o bagaço - atualmente utilizado nas usinas para gerar energia - o qual contém, segundo Campo (1999), Exergia específica de $10.259,34 \mathrm{~kJ} / \mathrm{kg}$ (praticamente metade que a da palha).

Com relação ao fluxo de referência da avaliação do ciclo de vida do álcool, considerando 10 t de palha por hectare, segundo Ripoli et al. (1990), e a porcentagem de queima de cana do Estado de São Paulo (75\%), segundo Macedo et al. (2004), a quantidade de perda de Exergia pela queimada (correspondente a 0,24 ha), é igual a $36,87 \cdot 10^{6} \mathrm{~kJ}$.

Dessa forma, ao se adicionar a quantidade de Exergia da queimada à quantidade de Exergia das emissões atmosféricas do ciclo de vida do álcool combustível, descontadas as exergias químicas das substâncias emitidas na queimada, a Exergia total das emissões atmosféricas é a soma de 3,68.10 $\mathrm{kJ}$ (Exergia química das emissões atmosféricas) com $36,87.10^{6} \mathrm{~kJ}$ (Exergia da queimada para 0,24 ha), resultando em $40,55 \cdot 10^{6} \mathrm{~kJ} / \mathrm{t}$ álcool.

Como a Exergia química de uma tonelada de álcool $\left(\mathrm{B}_{\mathrm{C} 2 \mathrm{H} 5 \mathrm{OH}}\right)$ é igual a $29,43 \cdot 10^{6} \mathrm{~kJ}$, a perda exergética das emissões do ciclo, inclusa a queimada, é de, aproximadamente, $38 \%$ a mais que a Exergia do álcool. 
A energia elétrica excedente no ciclo de vida do álcool, de acordo com a análise de inventário, é igual a $1,08.10^{6} \mathrm{~kJ}$, que representa a Exergia da energia elétrica. Essa Exergia, somada à Exergia do álcool, de 29,43.10 ${ }^{6} \mathrm{~kJ}$, resulta em um produto total do ciclo de vida do álcool com Exergia de 30,51.10 6 $\mathrm{kJ}$.

Contudo as perdas exergéticas das emissões atmosféricas do ciclo e da queimada são igual a $40,55.10^{6} \mathrm{~kJ}$, resultando em uma perda de Exergia de $10,04.10^{6} \mathrm{~kJ}$ ou em, aproximadamente, $33 \%$ a mais do total produzido pelo etanol e pela eletricidade.

Considerando a massa específica do álcool de 0,8 kg/l, de acordo com MCT (2003), e o dado, pelos cálculos anteriores, da Exergia específica do álcool de 29.430 kJ/kg, a Exergia química para um litro de álcool é 23.544 kJ.

Para a valoração da queimada, baseada em termos de Exergia do volume de álcool por hectare, é necessário dividir a quantidade de Exergia da queimada de um hectare $(\mathrm{kJ} / \mathrm{ha})$ pela Exergia de um litro de álcool $(\mathrm{kJ} / \mathrm{l})$.

Considerando que a quantidade de palha é de 10 toneladas por hectare, segundo Ripoli et al. (1990) e sabendo-se que a Exergia específica da palha é de $20.485,45 \mathrm{~kJ} / \mathrm{kg}$, a Exergia da queimada é $204.854 .500 \mathrm{~kJ} / \mathrm{ha}$. Finalmente, o equivalente exergético da queima da palhada, em termos de Exergia do álcool por hectare, é de $204.854 .500 \mathrm{~kJ} / \mathrm{ha}$ dividido por $23.544 \mathrm{~kJ} /$ litro de álcool, que corresponde a 8.701 litros de álcool por hectare.

Assim, para cada hectare de cana queimada, há uma perda de Exergia, ou seja, de trabalho útil, correspondente a 8.701 litros de álcool por hectare. Assim, a valoração do impacto físico-químico direto da queimada é de 8.701 litros de álcool por hectare queimado.

$\mathrm{Na}$ escala espacial do Brasil, a quantidade de palha queimada anualmente, segundo a Fiesp (2001), é de 48,3 milhões de toneladas, o que resulta na perda exergética anual de $989,4 \times 10^{12} \mathrm{~kJ}$ no Brasil, ou, em termos exergéticos, no equivalente a, aproximadamente, 42 bilhões de litros de álcool. 


\subsubsection{Avaliação do impacto e valoração ambiental pela Emergia}

O método emergético, o qual, segundo Odum (1996), se baseia na quantidade de energia solar equivalente utilizada pelos insumos, equipamentos, edificações e pelos serviços para a formação do produto, pode ser aplicada à avaliação e à valoração ambiental no que se refere ao uso ou ao consumo de recursos.

O diagrama emergético do ciclo de vida do álcool etílico hidratado combustível está representado na figura 23.

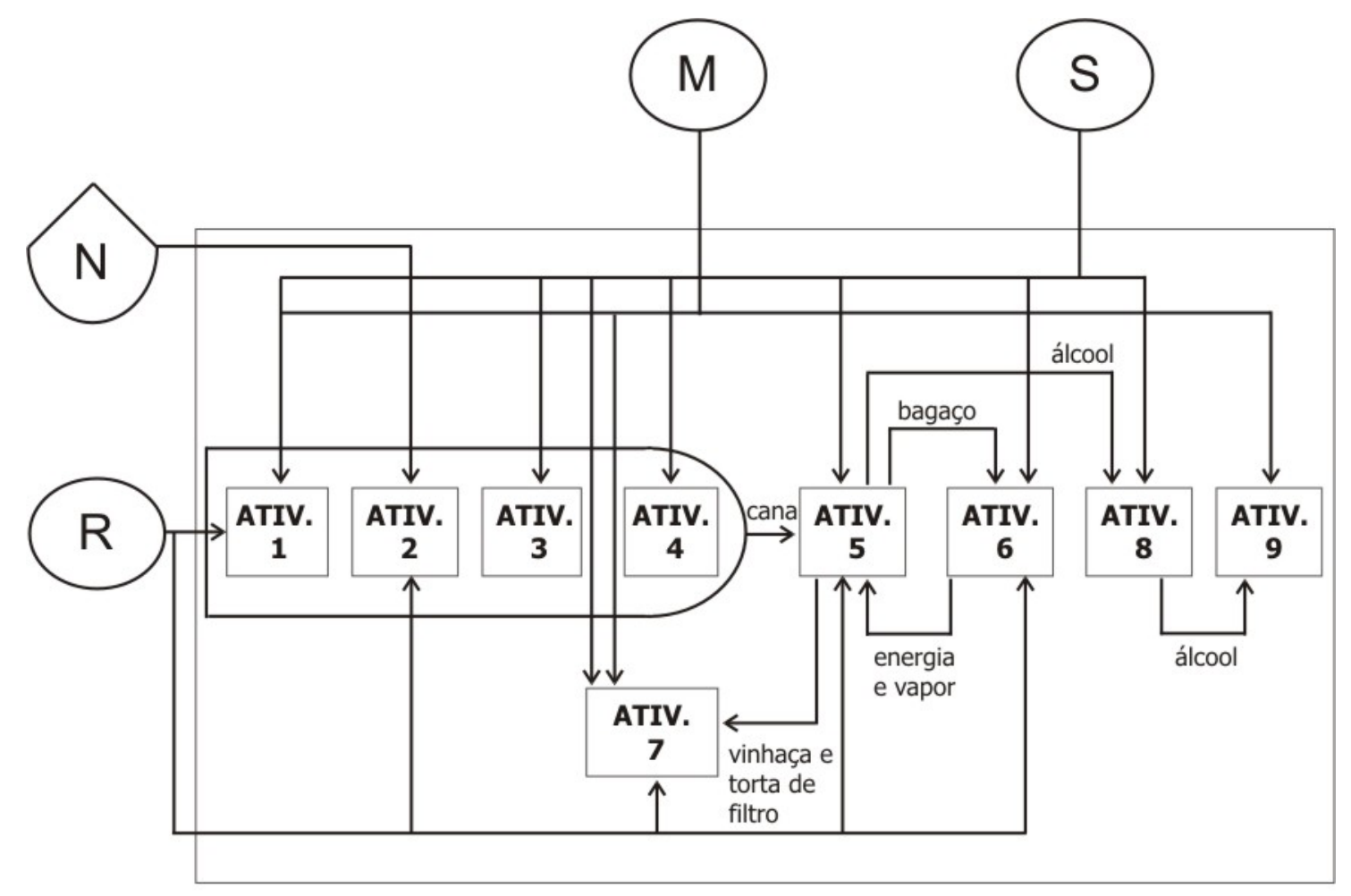

Figura 23 - Diagrama emergético do ciclo de vida do álcool combustível 
O memorial de cálculo para os insumos e os serviços do ciclo de vida do álcool está representado pela primeira utilização destes nas atividades do ciclo, sendo o procedimento semelhante para os usos subseqüentes. Os números à frente dos insumos e dos serviços no memorial de cálculo estão em concordância às referências na tabela 36 .

Memorial de cálculo:

\section{1. Água de chuva}

Chuva: $1500 \mathrm{~mm} / \mathrm{m}^{2} / a n o$, segundo Ortega (2003);

Energia livre de Gibbs para água: $4.940 \mathrm{~J} / \mathrm{kg}$, segundo Odum (1996);

Transformidade da água de chuva: $1,83.10^{4} \mathrm{sej} / \mathrm{J}$, segundo Odum (1996);

Energia $=1,5 \mathrm{~m}^{3} / \mathrm{m}^{2}$. ano $\times 10.000 \mathrm{~m}^{2} / \mathrm{ha} \times 1.000 \mathrm{~kg} / \mathrm{m}^{3} * 4.940 \mathrm{~J} / \mathrm{kg}=$ $7,42.10^{10} \mathrm{~J} / \mathrm{ha} / \mathrm{ano}$;

Emergia $=$ Energia ${ }^{*}$ Transformidade $=7,42.10^{10} \mathrm{~J} /$ ha.ano $\times 1,83.10^{4}$ sej $/ \mathrm{J}=$ $1,35.10^{15}$ sej/ha.ano.

\section{Perda de solo}

De acordo com Lanzotti (1999), a perda de solo para todas as atividades agrícolas da cultura de cana-de-açúcar é de cerca de 12,4 t/ha.ano e a quantidade de caloria contida em $1 \mathrm{~kg}$ do mesmo é 216 cal.

Transformidade do solo: $7,38.10^{4} \mathrm{sej} / \mathrm{J}$, segundo Odum (1996);

Então :

Energia $=12,4 \mathrm{t} /$ ha. ano $\times 216 \mathrm{cal} \times 4.186 \mathrm{~J} / \mathrm{cal}=1,12.10^{10} \mathrm{~J} / \mathrm{ha}$.ano .

Emergia $=$ Energia $*$ Transformidade $=1,12.10^{10} \mathrm{~J} /$ ha.ano $\times 7,38.10^{4} \mathrm{sej} / \mathrm{J}=$ $8,26.10^{14}$ sej/ha.ano.

\section{3. $\quad$ Combustíveis}

O memorial do cálculo da Emergia para combustíveis fósseis, no caso o diesel, está apresentado, a seguir, para a atividade 1. Para as demais atividades que utilizam diesel, a maneira de cálculo é a mesma, mudando o dado da quantidade de combustível utilizado. 
Para a atividade 1, a quantidade de diesel utilizada, de acordo com a análise de inventário, é $3,98 \mathrm{~kg} / \mathrm{t}$ álcool. A transformidade do diesel, segundo Odum (1996), é 6,6.10 $\mathrm{sej} / \mathrm{J}$ e seu poder calorífico, segundo Lanzotti (1999), é 27.570 kJ/kg. Então:

Emergia combustível $=3,98 \mathrm{~kg} / \mathrm{t}$ álcool *27.570.000 J/kg* 6,6.10 $\mathrm{sej} / \mathrm{J}=$ $7,25.10^{12}$ sej/ t álcool.

\section{Produtos químicos}

A quantidade de produtos químicos utilizada em cada etapa do ciclo de vida é especificada pelos agrotóxicos na análise de inventário do ciclo de vida do álcool combustível, sendo seu total, para a atividade 1 , igual a $0,1 \mathrm{~kg} / \mathrm{t}$ álcool. A transformidade dos produtos químicos é de $4,10.10^{14} \mathrm{sej} / \mathrm{Kg}$, em Odum (1996).

Então:

Emergia $=0,1 \mathrm{~kg} / \mathrm{t}$ álcool $\times 4,10 \cdot 10^{14} \mathrm{sej} / \mathrm{Kg}=3,64 \cdot 10^{13} \mathrm{sej} / \mathrm{t}$ álcool.

5. Insumos

Os dados dos insumos analisados nas atividades advêm da análise de inventário para o consumo de fertilizantes e de calcário. Para a atividade 1, são utilizados $96 \mathrm{~kg}$ de calcário para o fluxo de referência do ciclo de vida do álcool. A transformidade, para os insumos, é de $3,80.10^{12} \mathrm{sej} / \mathrm{kg}$, segundo Lanzotti (1999).

Portanto,

Emergia $=3,80 \cdot 10^{12} \mathrm{sej} / \mathrm{kg} .96 \mathrm{~kg} / \mathrm{t}$ álcool $=3,65 \cdot 10^{14} \mathrm{sej} / \mathrm{t}$ álcool.

\section{Equipamentos}

Os cálculos referentes aos equipamentos são realizados a partir da massa e da sua respectiva transformidade.

Para o preparo convencional do solo, a partir dos dados primários, têmse:

- Massa de equipamentos por hectare: 1,3 kg/ha.ano;

- Vida útil dos equipamentos utilizados: 15 anos; 
- Transformidade dos equipamentos: $6,7.10^{12} \mathrm{sej} / \mathrm{kg}$, segundo Lanzotti (1999);

- Área correspondente para a atividade 1: 0,048ha.

Então,

Emergia dos equipamentos $=1,3 \mathrm{Kg} / \mathrm{ha}$.ano $\times 6,7.10^{12} \mathrm{sej} / \mathrm{kg}=8,9.10^{12}$ sej/ha.ano.

\section{Mão-de-obra}

A quantidade de empregos diretos de trabalho braçal é considerada, para cada atividade, de acordo com os resultados da análise de inventário. Para o preparo convencional do solo, têm-se:

- Quantidade relativa de trabalhadores para 1 t de álcool: 0,003 pessoas (p);

- Horas trabalhadas por dia: 8 horas;

- Dias trabalhados por ano: 120 dias;

- Consumo energético por dia do trabalhador: 3200cal, segundo Odum (1996);

- Fator de Conversão: 1cal = 4186J, segundo Online Conversion (2003);

- Transformidade do trabalhador: $7,66.10^{5} \mathrm{sej} / \mathrm{J}$, segundo Odum (1996).

Portanto:

Energia $=0,003 \mathrm{p} / \mathrm{t}$ álcool $\times 8 \mathrm{~h} / 24 \mathrm{~h} \times 120 \mathrm{~d} \times 3200 \mathrm{cal} / \mathrm{p} . \mathrm{d} \times 4186 \mathrm{~J} / \mathrm{cal}=$ $1,47.10^{5} \mathrm{~J} /$ tálcool

Emergia $=$ Energia $x$ Transformidade $=1,47.10^{5} \mathrm{~J} / \mathrm{t}$ álcool * $7,66.10^{5} \mathrm{sej} / \mathrm{J}=$ $1,13.10^{11} \mathrm{sej} / \mathrm{t}$ álcool.

\section{Cana-de-açúcar}

Para os cálculos emergéticos, considerou-se a quantidade de cana necessária para o plantio na área de renovação do canavial (0,048 ha), segundo o resultado do ICV, o qual é $672 \mathrm{~kg}$.

A transformidade da cana foi calculada a partir de método iterativo na planilha emergética, de acordo com a seguinte fórmula: 
Transformidade = Emergia total da parte agrícola para $1 \mathrm{t}$ álcool $/$ produção de cana para $1 \mathrm{t}$ álcool.

Portanto:

Transformidade da cana $=1,78.10^{15} \mathrm{sej} / \mathrm{t}$ álcool $/ 15.720 \mathrm{~kg} / \mathrm{ha}$.ano $=$ $1,13.10^{11} \mathrm{sej} / \mathrm{kg}$.

Então,

Emergia da cana $=$ Massa $x$ Transformidade $=672 \mathrm{~kg}$ cana $/ \mathrm{t}$ álcool $\mathrm{x}$ $1,13 \cdot 10^{11} \mathrm{sej} / \mathrm{kg}=7,59 \cdot 10^{13} \mathrm{sej} / \mathrm{t}$ álcool.

\section{Edificação}

As edificações utilizadas para todas as atividades da parte agrícola foram contabilizadas na atividade de colheita. Os dados das edificações foram obtidos pelos dados primários.

Dados:

Área construída: $4100 \mathrm{~m}^{2}$;

Custo da construção: $\mathrm{R} \$ 700,00 / \mathrm{m}^{2}$, segundo Peres (2004);

“Emergy Money Ratio": 3,7.10² sej/dólar, em Odum (1996);

Cotação: 1 US $\$=R \$ 3,00$, em 07/03/2004;

Área agrícola referente aos dados primários: 22.000 hectares;

Custo anual por hectare em dólares: $(4.100 \times 700 / 3) /(35.000 \times 15)=1,8$ US\$/ha.a;

Emergia = Custo $\mathrm{x}$ "Emergy Money Ratio" = 1,8 US\$/ha.a x 3,7.10 12 sej/dólar = $6,74.10^{12} \mathrm{sej} / \mathrm{ha}$.

\section{Mão-de-obra especializada}

A quantidade de pessoas que trabalham como mão-de-obra especializada é considerada de acordo com os resultados da análise do inventário. Alocaramse os profissionais técnicos da área agrícola para esta categoria. Desse modo, têm-se:

- Quantidade relativa de trabalhadores para $1 \mathrm{t}$ de álcool: 0,0005 p; 
- Horas trabalhadas por dia: 8 horas;

- Dias trabalhados por ano: 315 dias;

- Consumo energético por dia do trabalhador especializado: $2.500 \mathrm{cal}$, segundo Odum (1996);

- Fator de conversão: 1 cal = 4.186 J, em Online Conversion (2003);

- Transformidade do trabalhador especializado: $7,66.10^{6} \mathrm{sej} / \mathrm{J}$, segundo Odum (1996).

Portanto,

Energia $=0,0005 \mathrm{p} / \mathrm{t}$ álcool $\times 8 \mathrm{~h} / 24 \mathrm{~h} \times 315 \mathrm{~d} \times 2500 \mathrm{cal} / \mathrm{p} . \mathrm{d} \times 4186 \mathrm{~J} / \mathrm{cal}=$ $5,99.10^{5} \mathrm{~J} / \mathrm{t}$ álcool;

Emergia $=$ Energia $\times$ Transformidade $=5,99.10^{5} \mathrm{~J} / \mathrm{t}$ álcool $\times 7,66.10^{6} \mathrm{sej} / \mathrm{J}=$ $4,59.10^{12}$ sej/t álcool.

\section{4.}

De acordo com Odum (1996), a energia livre de Gibbs para a água é $4.940 \mathrm{~J} / \mathrm{kg}$ e sua transformidade é $110.000 \mathrm{sej} / \mathrm{J}$. Como se utiliza $1,29.10^{5} \mathrm{~kg}$ de água por tonelada de cana, a sua Emergia é igual a:

Emergia $=1,29.10^{5} \mathrm{~kg} / \mathrm{t}$ álcool $\times 4.940 \mathrm{~J} / \mathrm{kg} \times 110.000 \mathrm{sej} / \mathrm{J}=7,02.10^{13} \mathrm{sej} / \mathrm{t}$ álcool.

\section{Automóvel}

A Emergia de um carro foi calculada por Macgrane (1994) e possui um valor de $1.54 .10^{16}$ sej/ano. Como foi considerado que o consumo de 1 tonelada de álcool ocorra em 1 ano, a Emergia do automóvel, para o uso de 1 tonelada de álcool, é $1.54 .10^{16} \mathrm{sej} / \mathrm{t}$ álcool.

A planilha emergética, com os resultados da avaliação e valoração emergética das atividades do ciclo de vida do álcool, é apresentada na tabela 32. 


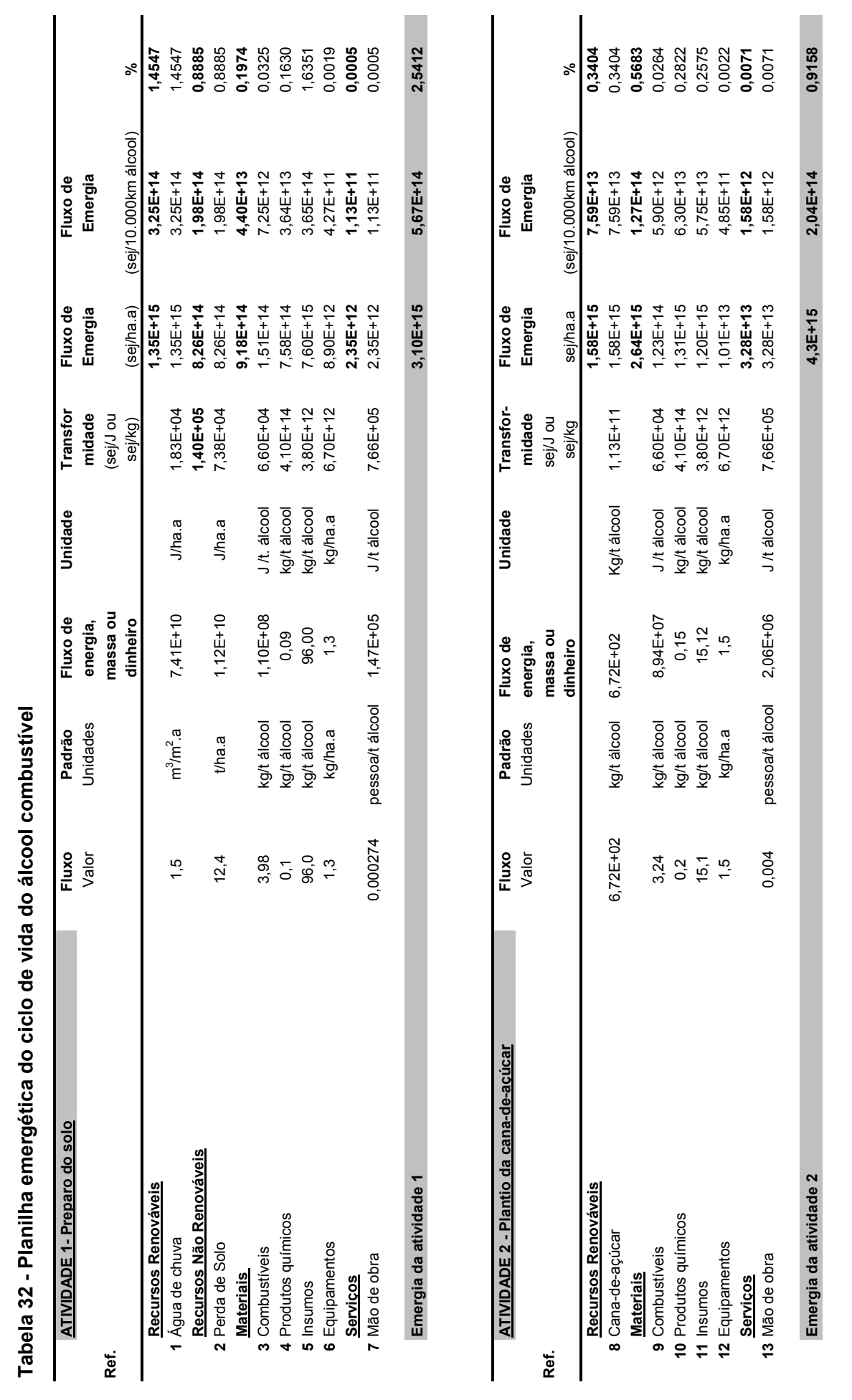




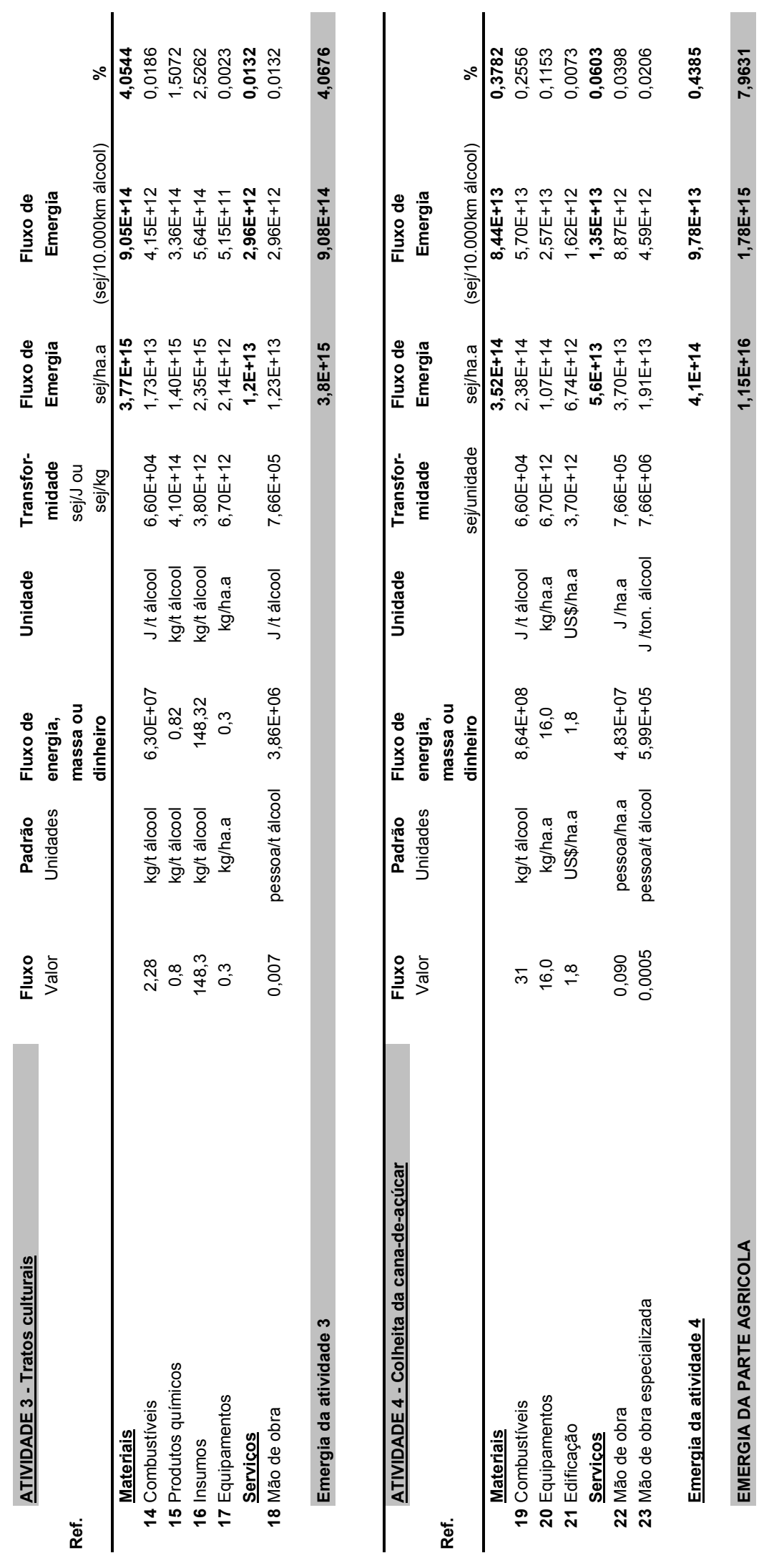




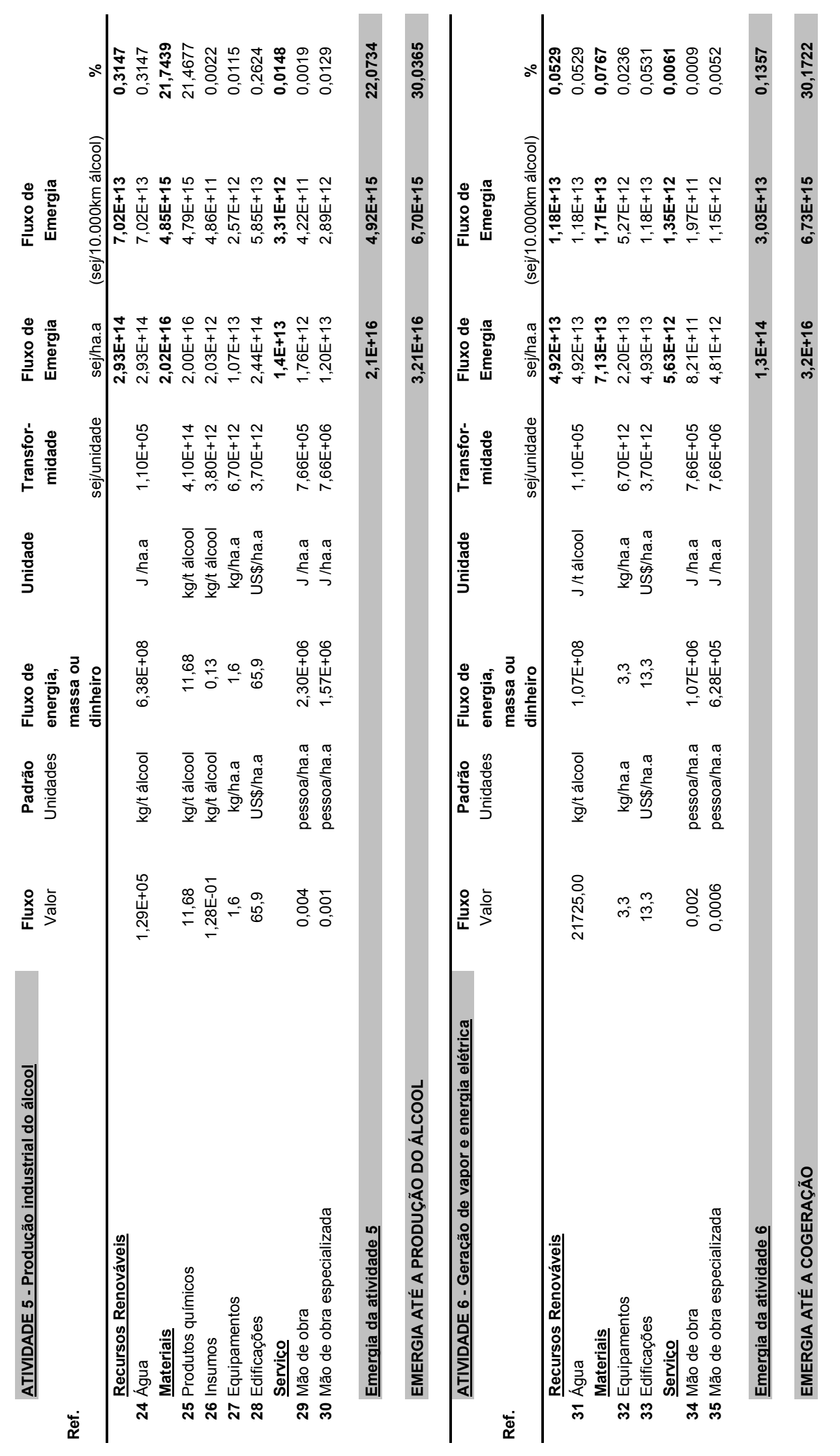




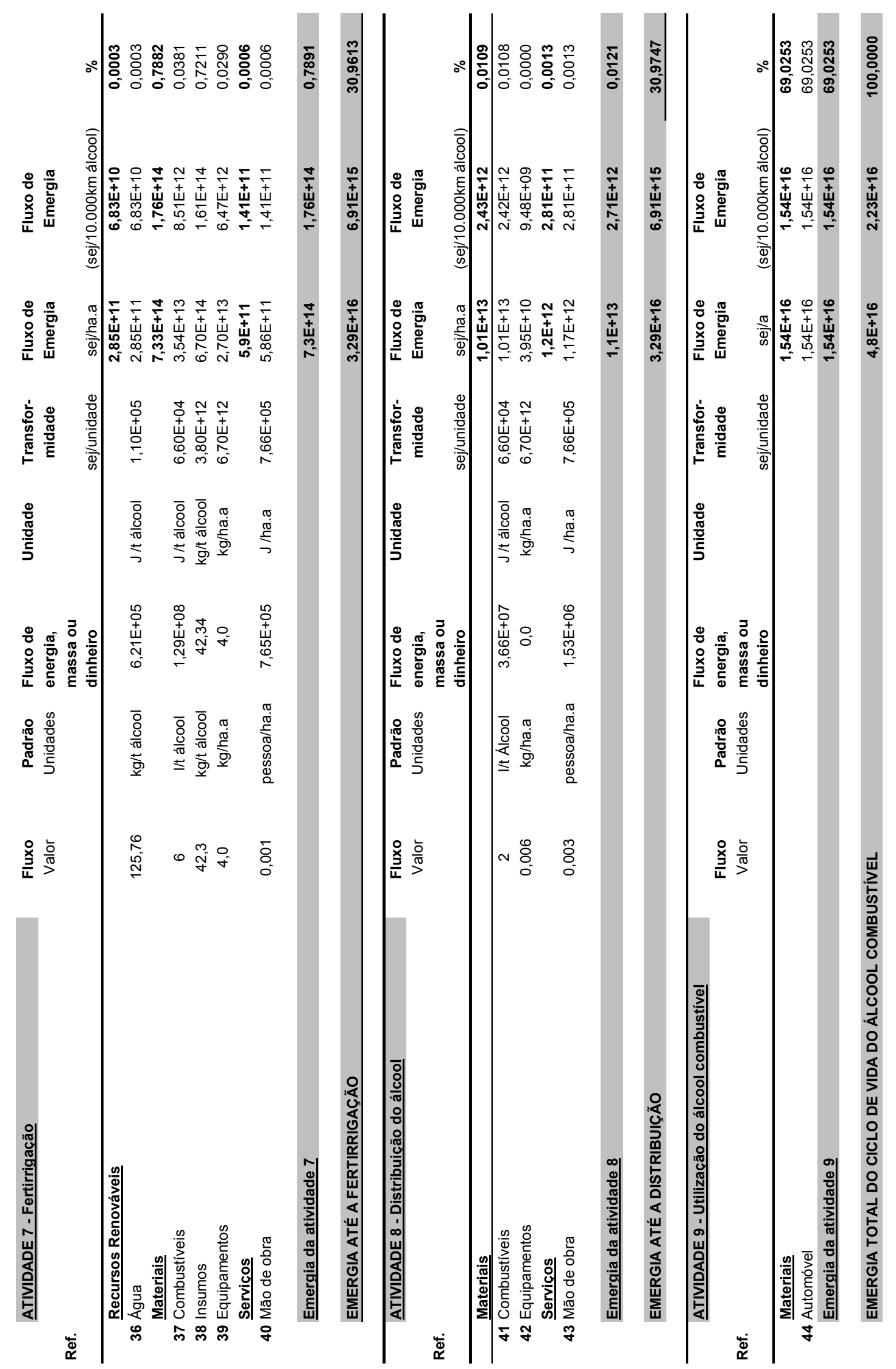


O resumo dos resultados emergéticos do ciclo de vida do álcool combustível é apresentado na tabela 33 pela Emergia das principais categorias dos recursos utilizados.

Tabela 33 - Emergia dos recursos do ciclo de vida do álcool combustível

\begin{tabular}{cccc}
\hline Recursos & $\begin{array}{c}\text { Emergia (sej/ } \\
\text { ha.ano) }\end{array}$ & $\begin{array}{c}\text { Emergia (sej/ } \\
10.000 \mathrm{~km} \text { álcool) }\end{array}$ & $\begin{array}{c}\text { Porcentagem } \\
(\%)\end{array}$ \\
\hline Renováveis & $3,28.10^{15}$ & $4,83.10^{14}$ & 2,16 \\
Não-renováveis & $8,26.10^{14}$ & $1,98.10^{14}$ & 0,89 \\
Recursos naturais & & & \\
(Renováveis + Não-renováveis) & $4,10.10^{15}$ & $6,81.10^{14}$ & 3,05 \\
Materiais & $4,41.10^{16}$ & $2,16.10^{16}$ & 96,85 \\
Serviços & $1,25.10^{14}$ & $2,32.10^{13}$ & 0,10 \\
Econômicos & & & \\
(Materiais + Serviços) & $4,42.10^{16}$ & $2,16.10^{16}$ & 96,95 \\
Total & & & 100 \\
(Recursos Naturais + & $4,83.10^{16}$ & $2,23.10^{16}$ & \\
Econômicos) & & & \\
\hline
\end{tabular}

Pelas tabelas 32 e 33, observa-se que o maior consumo emergético do ciclo de vida do álcool é devido ao materiais, principalmente para a produção do automóvel e pelo uso intensivo de produtos químicos, durante a produção industrial. A grande quantidade de insumos agrícolas também influenciou a alta Emergia dos materiais. Verificou-se que, aproximadamente, $70 \%$ do consumo de energia solar equivalente do ciclo de vida do álcool ocorre durante a fase de utilização do produto, devido à grande Emergia embutida na produção do veículo.

O alto consumo de água contribui para que a quantidade emergética dos recursos renováveis seja a segunda maior, embora bem inferior à Emergia dos materiais utilizados.

Os resultados dos índices emergéticos do ciclo vida do álcool etílico hidratado combustível são apresentados na tabela 34 e comentados a seguir. 
Tabela 34 - Índices emergéticos do ciclo vida do álcool etílico hidratado combustível

\begin{tabular}{ccc}
\hline Índices Emergéticos & Valor & Unidade \\
\hline Transformidade do ciclo de vida & $2,23.10^{13}$ & sej/kg \\
Taxa de carga ambiental do ciclo de vida & 45,23 & - \\
Renovabilidade do ciclo de vida & 2 & $\%$ \\
Taxa de investimento de Emergia do ciclo de vida & 31,77 & - \\
Rendimento Emergético do ciclo de vida & 1,03 & - \\
Sustentabilidade do ciclo de vida & 0,02 & - \\
\hline
\end{tabular}

\section{$\underline{\text { Transformidade do ciclo de vida }}$}

O valor calculado de $2,23.10^{13} \mathrm{sej} / \mathrm{kg}$ para a transformidade do ciclo de vida do álcool é alta, em comparação à transformidade da produção do álcool, de acordo com Lanzotti e Ortega (1999), de 3,6.10 ${ }^{10} \mathrm{sej} / \mathrm{kg}$. Isso se deve à incorporação de mais atividades na avaliação, quando se estuda o ciclo de vida de produtos.

Uma forma ainda inédita em estudos emergéticos ocorre através da unidade funcional. Portanto, para uma média de transporte em veículo a álcool para percorrer $10.000 \mathrm{~km}$, são necessários $2,23.10^{16} \mathrm{sej}$. Ou seja, para cada km percorrido com álcool são consumidos $2,23.10^{12}$ sej de energia solar equivalente.

\section{Taxa de carga ambiental do ciclo de vida}

O valor da taxa de carga ambiental encontrada para o ciclo de vida estudado é de 45,23, considerado extremamente alto. Tal resultado representa que a energia solar equivalente dos recursos não-renováveis e dos recursos advindos do sistema econômico são 45,23 vezes maiores que e energia solar equivalente dos recursos renováveis utilizados. Isso se deve, principalmente, à grande Emergia incorporada no automóvel e nos produtos químicos utilizados, principalmente, na fase industrial. 


\section{$\underline{\text { Renovabilidade do ciclo de vida }}$}

A taxa de renovabilidade do ciclo é de $2 \%$, indicando que o álcool é intensamente dependente dos insumos não-renováveis e da economia, principalmente devido à grande Emergia incorporada no automóvel e nos produtos químicos utilizados.

\section{$\underline{\text { Taxa de investimento de Emergia do ciclo de vida }}$}

A taxa de investimento de Emergia, para o ciclo de vida do álcool, é de 31,77 , indicando que a energia solar equivalente dos insumos utilizados advindos da economia é 31,77 vezes maior que a energia solar equivalente dos recursos naturais utilizados. Isso se deve, também, à grande Emergia incorporada no automóvel e nos produtos químicos utilizados.

\section{$\underline{\text { Rendimento Emergético do ciclo de vida }}$}

O rendimento emergético de 1,03 significa que o ciclo de vida do álcool combustível fixa energia solar com um ganho de 3\%. O fato deve-se, principalmente, às características fisiológicas da cana-de-açúcar no tocante ao rápido crescimento celular pelo processo de fotossíntese.

\section{Sustentabilidade do ciclo de vida}

O índice de sustentabilidade encontrado é de 0,02, o que significa que a taxa de carga ambiental é, aproximadamente, quarenta e cinco vezes maior que o rendimento emergético.

Portanto, muitas melhorias devem ser realizadas a fim de se aumentar a sustentabilidade do ciclo, tais como a utilização do álcool em veículos de baixa transformidade, a redução no uso de produtos químicos e as melhorias na eficiência de utilização do álcool. 


\section{Capítulo 5. Conclusões}

Atualmente, uma das formas mais integradas, completas e eficazes para a realização da gestão ambiental de atividades produtivas é baseada no ciclo de vida do produto. Dessa forma, os impactos ambientais devem ser avaliados, não somente pelo processo produtivo ou por uma única atividade, mas pelas fases do ciclo de vida do produto, desde a extração da matéria-prima até a reutilização, a reciclagem ou a disposição final.

Nesse contexto, a ACV é uma das ferramentas mais úteis para a avaliação ambiental, embasando medidas mitigadoras preventivas, caracterizadas por ações de produção limpa e ecodesign. O monitoramento e a retroalimentação do sistema de gestão ambiental podem ser aplicados, também, nas atividades do ciclo de vida do produto.

A gestão ambiental, baseada no produto, pode se tornar prática nas atividades produtivas, com a implementação de políticas públicas. Estas podem ser baseadas em estudos de ACV e aplicadas por meio de instrumentos econômicos que incentivem o consumo de produtos com menores impactos ambientais durante o ciclo de vida.

Uma das contribuições deste trabalho é o estudo das aplicações de três métodos para a AICV do etanol hidratado combustível. Os métodos utilizados são o tradicional para ACV, pelo EDIP e métodos da Termodinâmica Clássica, pela exergia e da Termodinâmica aplicada a outras ciências, pela emergia. Além disso, a aplicação dos métodos da Termodinâmica para a valoração ambiental sinaliza uma forma de aproximação entre alguns conceitos teóricos da Economia e alguns aspectos práticos da Engenharia e de sistemas vivos. 
A exergia aplicada às emissões mostra-se como uma medida do trabalho mecânico desperdiçado que causa impacto físico-químico direto no meio.

A emergia, por sua vez, mede a quantidade de energia solar incorporada aos insumos e aos serviços pelo trabalho ecossistêmico, durante as suas formações, e apresenta uma abordagem mais ampla que a exergia, incluindo os sistemas naturais e da economia. Como a emergia avalia e valora o recurso a partir de sua cadeia produtiva, desde a formação dos recursos naturais primários, sua aplicação para estudos de ACV mostra-se compatível e aplicável.

Assim, as avaliações pela emergia e pela exergia podem retratar, respectivamente, a eficiência ecossistêmica e a eficiência termodinâmica do ciclo de vida de um produto. Portanto, as aplicações da emergia e da exergia neste trabalho são complementares, visto que a emergia se aplica aos insumos e a exergia, às emissões e são factíveis como métodos de AICV.

Dentre os métodos utilizados, o EDIP mostra-se como o mais direto para a avaliação de impacto ambiental, um dos motivos que o torna um dos métodos mais utilizados em ACV. Os resultados baseados no EDIP apresentam as atividades de maiores potenciais de impacto ambiental para cada categoria.

A atividade da colheita de cana é a de maior potencial de impacto para: potencial de aquecimento global, potencial de formação fotoquímica de ozônio troposférico, potencial de acidificação e potencial de toxicidade humana. A principal causa de a atividade de colheita ser a de maior potencial para estas categorias é a queimada da palha da cana-de-açúcar.

A atividade de preparo do solo é a de maior potencial de impacto para as categorias de consumo de recursos não-renováveis e potencial de ecotoxicidade da água. A principal causa desses altos potenciais é o uso intensivo de diesel e de agrotóxicos, respectivamente.

A atividade de tratos culturais apresenta-se como a de maior potencial para as categorias de eutrofização e de ecotoxicidade do solo. Isso se deve ao uso intensivo de agroquímicos. 
A atividade de processo industrial é a de maior consumo de recursos renováveis, devido, principalmente, ao alto consumo de água.

Com relação aos resultados da Exergia, para cada litro de álcool, há uma perda de exergia pelas emissões atmosféricas de seu ciclo de vida que equivale à exergia de, aproximadamente, 1,38 litro de álcool. A contribuição da queimada da palha da cana-de-açúcar, frente ao total de perda exergética das emissões atmosféricas, é de, aproximadamente, 91\%, ou seja, equivalente à exergia de 1,26 litro de álcool para cada litro de álcool produzido, considerando que $25 \%$ da cana colhida seja crua. Portanto, para um melhor aproveitamento energético do ciclo de vida do álcool etílico hidratado combustível, indica-se a utilização da cana crua para o processamento industrial do álcool e o uso da palha para cogeração de energia, juntamente com o bagaço.

Como se verifica, a eliminação da queimada traz ganhos expressivos, em termos energéticos e ambientais, além de produtivos, pela retenção da sacarose perdida pela exsudação do colmo durante a queima.

A avaliação emergética é realizada de acordo com as regras e a álgebra da emergia, obtendo-se resultados coerentes que expressam o alto impacto do uso de veículos automotores. Os dados coletados advêm das atividades reais do ciclo de vida do etanol hidratado combustível e os resultados são apresentados, também, com base no fluxo de referência e na unidade funcional.

Tal procedimento foi desenvolvido, a fim de se aplicarem os três métodos na mesma base de referência. Para estudos de ACV que utilizem somente o método da Emergia, indica-se a avaliação do sistema de produto, a partir dos dados totais dos processos.

De acordo com os resultados da Emergia, são fundamentais para melhorar o rendimento ecossistêmico das atividades do ciclo de vida do álcool o uso de veículos produzidos de forma mais sustentável, a redução no uso de produtos químicos e a utilização mais eficiente do álcool combustível.

Com base neste ACV, pode-se indicar algumas ações que tendem a melhorar a performance ambiental do ciclo de vido do álcool combustível, entre elas: a eliminação da queimada, a redução do uso de agrotóxicos, de 
combustível fóssil, do transporte, meios mais eficientes de uso do álcool combustível, a utilização de veículos produzidos de forma menos intensiva no consumo de materiais e energia e o uso do álcool combustível produzido seguindo destas indicações nas máquinas agrícolas e no transporte. Contudo, outros estudos comparativos são indicados para se avaliar a diferença de resultados do ciclo com estas indicações.

Os resultados do ACV do álcool etílico hidratado combustível podem trazer subsídios para a comunidade científica, para produtores de cana-deaçúcar e etanol, para a sociedade em geral e, principalmente, para o consumidor do etanol, assim como para o desenvolvimento de políticas públicas que regulamentem as atividades do setor sucroalcooleiro.

A avaliação ambiental baseada no ciclo de vida dos produtos incorpora uma visão integrada para as soluções dos problemas ambientais, tornando-as mais eficazes. Além do benefício ambiental que a estratégia baseada no ciclo de vida pode trazer, novas soluções e atividades são desenvolvidas, tendo em vista a otimização no uso de materiais e de energias.

Concluindo, a gestão ambientalmente adequada baseada no produto pode reduzir o consumo das fontes naturais, a geração de resíduos, de efluentes e de emissões, ampliando as atividades econômicas e a quantidade de empregos. Desse modo, a engenharia de ciclo de vida pode incentivar o desenvolvimento econômico com melhorias ambientais e ganhos sociais, auxiliando a sustentabilidade. 


\section{Referências Bibliográficas}

ASSOCIAÇÃO BRASILEIRA DE NORMAS TÉCNICAS (1996). NBR ISO 14001 Sistema de Gestão Ambiental - Especificação e diretrizes para uso. Brasil: ABNT. 22p.

ASSOCIAÇÃO BRASILEIRA DE NORMAS TÉCNICAS (2001). NBR ISO 14040 Gestão Ambiental - Avaliação do ciclo de vida - Princípios e estrutura. Brasil: ABNT. Novembro. 10p.

ASSOCIAÇÃO BRASILEIRA DE NORMAS TÉCNICAS (2004a). NBR ISO 14041 Gestão Ambiental - Avaliação do ciclo de vida - Definição do objetivo e escopo e análise de inventário. Brasil: ABNT. Maio. 25p.

ASSOCIAÇÃO BRASILEIRA DE NORMAS TÉCNICAS (2004b). NBR ISO 14042 Gestão Ambiental - Avaliação do ciclo de vida - Avaliação do impacto do ciclo de vida. Brasil: ABNT. Maio. 17p.

AB'SÁBER, A.N. (1998). Bases Conceituais e Papel do Conhecimento na Previsão de Impactos. In: MÜLLER-PLANTENBERG, C. \& AB'SABER, A. N. (orgs). Previsão de Impactos: o Estudo de Impacto Ambiental no Leste, Oeste e Sul. Experiências mo Brasil, na Rússia e na Alemanha. 2.ed. São Paulo, Editora da Universidade de São Paulo. Cap.1, p.27-49.

AGÊNCIA NACIONAL DE VIGILÂNCIA SANITÁRIA (2003). Composição química de produtos químicos. In: http:// www.anvisa.gov.br /legis/ portarias 110_85.htm (14/04/03)

AGRO-FAUNA COMÉRCIO DE INSUMOS LTDA (2003). Insumos para a cultura de cana-de-açúcar. In: http:// www.agro-fau_na.com.br . (10/03/03). 
ALBRITTON, D. L. et al. (1995). Trace gas radiative forcing indices. In: Climate change 1994, radiactive forcing of climate change and na evaluation of the IPCC IS92 emission scenarios. United Kingdon: Cambridge University Press.

ALMEIDA, J. R. (s.d.). Álcool e Distilaria. Piracicaba: Escola Superior de Agricultura "Luiz de Queiroz" (ESALQ). Universidade de São Paulo (USP).

ALTING, L. e LEGARTH, J. B. (1995). Life cycle engineering and design. Annals of the CIRP, v.44. n.2.

ALVARENGA, S. R. (1997). A análise das Áreas de Proteção Ambiental enquanto instrumento da Política Nacional do Meio Ambiente: o caso da APA Corumbataí, SP. São Carlos, SP. Dissertação (Mestrado) - Escola de Engenharia de São Carlos, Universidade de São Paulo.

ALVES, I. T. (1991). Estudo de Impacto Ambiental da Destilaria dos Pilões. Relatório de Impacto Ambiental. Secretaria do Meio Ambiente do Estado de São Paulo. Coordenadoria de Planejamento Ambiental. Imprensa Oficial do Estado. Araraquara, SP.

AMAZONAS, M. (1994). Economia do Meio Ambiente: Uma Análise da Abordagem Neoclássica a partir de Marcos Evolucionistas e Institucionalistas. Dissertação de Mestrado, Instituto de Economia. Universidade Estadual de Campinas - IE/UNICAMP, novembro.

ANDERSOM-SKÖLD, Y.; GRENNFELT, P.; PLEIJEL, K. (1992). Photochemical ozone creation potentials: a study of different concepts. F. Int. Air Waste Manage. Assoc. 42 (9), 1152-1158.

ANFAVEA - Associação Nacional dos Fabricantes de Veículos Automotores (2004). Dados de produção dos veículos nacionais. In: http://www.anfavea.com.br/lndex.html

ANTUNES, D.N. (2001). Critérios públicos e sociais versus critérios de mercado na avaliação do meio-ambiente. Dissertação (Mestrado). Instituto de Economia. Universidade Estadual de Campinas - IE/UNICAMP. 
ANTUNES, D.N. Efeitos da valoração monetária do meio ambiente. Entrevista oral com Professor do Centro de Estudos Sindicais e de Economia do Trabalho. Instituto de Economia. Universidade Estadual de Campinas UNICAMP (7/10/2004).

AREVAlO, A. R. (1980). Poluição e defensivos em cana-de-açúcar. PLANALSUCAR.

ATKINS, P.W. (1994). Physical Chemistry. Oxford: Oxford UK

AYRES, R. U.; AYRES, L. W.; MARTINAS, K. (1998). Exergy waste accounting, and life-cycle analysis. Energy - International Journal. n, 23. p. 355 - 363.

BACCHI, M. R. P. (2004). A variabilidade dos preços do açúcar e do álcool em São Paulo. Visão Agrícola. Ano 1, v. 1, ISSN 1806-6402.p. 100-105.

BAKSHI , B. R., A (2002). Thermodynamic Framework for Ecologically Conscious Process Systems Engineering Computers and Chemical Engineering, special issue on selected papers from PSE 2000, 26, 2, 269-282.

BARBIERI, J. C. (1997). Políticas públicas indutoras de inovações tecnológicas ambientalmente saudáveis nas empresas. RAP. Rio de Janeiro, v.31, n.2, p.135-52, mar/abr.

BARNTHOUSE et al. (1997). Life-Cycle Impact Assessment: The State-of-theArt. Report of the SETAC Life-Cycle Assessment (LCA) Impact Assessment Workgroup, SETAC LCA Advisory Group. Society of Environmental Toxicology and Chemistry (SETAC) and SETAC Foundation for Environmental Educatio, Pendacola, FL, USA.

BEJAN, A. (1988). Advanced Engineering Thermodynamics. John Wiley \& Sons, New York, N.Y.

BEJAN, A.; TSATSARONIS, G.; MICHAEL, M. (1996). Thermal Design and Optimization. Wiley-Interscience Publication, John Wiley \& Sons, USA \& Canada. 
BORRERO, M.A.V.; PEREIRA, J.T.V.; MIRANDA, E.E. (2003). An environmental management method for sugar cane alcohol production in Brazil. Biomass \& Bioenergy. See also: www.sciencedirect.com (05/05/2003).

BRAILE, P. M. e CAVALCANTI, J. E. W. A. (1979). Manual de Tratamento de Águas Residuárias Industriais. São Paulo, Companhia de Tecnologia de Saneamento Ambiental - CETESB.

BRASIL (1988). Constituição da República Federativa do Brasil: artigo 225. Legislação Federal, Controle da Poluição Ambiental, São Paulo. Série Documentos. CETESB.

BRASIL (1981). Leis Federal n. 6938 de 31 de agosto. Dispõe sobre a Política Nacional do Meio Ambiente, seus fins e mecanismos de formulação e aplicação. Legislação Federal, Controle da Poluição Ambiental. Série Documentos. CETESB. São Paulo, SP.

BRASIL (1986). Resolução CONAMA n. 01, de 23 de janeiro. Legislação Federal, Controle da Poluição Ambiental. Série Documentos. CETESB, São Paulo, SP.

BRASIL (1986). Resolução CONAMA n. 20, de 18 de junho. Classifica as águas doces, salobras e salinas do Território Nacional em nove classes, segundo seus usos preponderantes. Legislação Federal, Controle da Poluição Ambiental. Série Documentos. CETESB, São Paulo, SP.

BRODYANSKI, V. M.; SORIN, M. V.; LE GOFF, P. (1994). The effiency of industrial process: Exergy Analysis and Optimization. London, Elsevier.

BROWN , M.T (1993). Workshop on Emergy Analysis. Siena, 20-25 Setembro.

BROWN , M.T; HARENDEEN, R.A (1996). Embodied energy analysis and Emergy analysis: a comparative view. Ecological Economics, 19. p. 219-235.

CALZONID, J. et al. (2000). Bioenergy for Europe: Which ones fit best? - A Comparative Analysis for the Community. Final Report November 2000 
Research funded in part by The European Commission in the framework of the FAIR V Programme. Contract CT 983832.

CAMPBELL, D.E. ( 2001). A revised Solar Transformity for tidal Energy Received by the Earth and Dissipated Globally: Implications for an Emergy Analysis. Proceedings: Second Biennial Emergy Research Conference. Gainesville, FL - EUA. Setembro.

CAMPO, E. R. B. del. (1999). Avaliação termoeconômica do sistema de cogeração da usina Vale do Rosário. Campinas, SP: Tese (Doutorado), Faculdade de Engenharia Mecânica, Universidade Estadual de Campinas.

CASTRO, O. M. (1985). Aspectos de manejo do solo. Fundação Cargill. IApresentado ao $1^{\circ}$ Encontro do Uso da Terra na região do Vale do Paranapanema./

CENTURION, R.E.B; DERÍSIO, J.C (1992). Evolução do controle da poluição das indústrias sucroalcooleiras no Estado de São Paulo. In: SEMINÁRIO INTERNACIONAL BRASIL-CUBA. TECNOCANA-92. Araras. Anais. Companhia de Tecnologia de Saneamento Ambiental - CETESB. Centro de Ciências Agrárias, UFSCar, Set.

COMPANHIA DE TECNOLOGIA DE SANEAMENTO AMBIENTAL (1985). Nota sobre tecnologia de controle na fabricação de açúcar e álcool. Documento Técnico CETESB. Dez.

CIAMBRONE, D. F. (1997). Environmental Life Cycle Analysis. New York: Lewis.

COASE, R. (1960). The Problem of Social Cost. Journal of Law and Economics, vol.3.

COLLINS, D.; ODUM, H.T. (2001). Calculating Transformities with an Eigenvector Method. Proceeding. Second Biennial Emergy Research Conference. Gainesville, FL, EUA. Set. 
COMAR, V. (1995). Análise Custo Benefício e Multicritérios - Considerações . In: Tauk-Tornisielo, S.M, Gobbi, N., Foresti, C., Lima, S.T. Análise Ambiental: estratégias e ações Ed. Queiroz, Fundação Salim Farah Maluf, UNESP.

COMAR, V. (1999). Emergy Evaluations of Organic and Conventional Horticultural. Proceedings of the First Biennial Emergy Analysis Research Conference, Ginesville, FL, USA.

CONNELLY, L.; KOSHLAND, C. P. (1997). Two aspects of consumption: using and exergy-based measure of degradation to advance the theory and implementation of industry ecology. Resources, Conservation and Recycling. $\mathrm{n}$ 9. p. $199-217$.

COPERSUCAR (1989). Estudo de Impacto Ambiental: Destilaria Batatais S.A. Secretaria do Meio Ambiente do Estado de São Paulo. Piracicaba, SP. Coordenadoria de Planejamento Ambiental. Imprensa Oficial do Estado de São Paulo.

CORBINI, J. L. (1987). Operações agrícolas em tratos culturais. In: PARANHOS, S.B., coord. Cana-de-açúcar: cultivo e utilização. 1.ed. Campinas, Fundação Cargill, vol.1, p.333-370.

CORNELISSEN, R. L. (1997). Thermodynamics and Sustainable Development. Ph. D. Thesis. University of Twente, The Netherlands.

CRISTOPHER, M. (1993). Logistic and competetive strategy. European Management Journal. v.11 n. 2 p. 258-61.

CRUZ, R.L. (1991). Efeito da aplicação de vinhaça sobre o solo e água subterrânea. São Carlos. Tese (Doutorado) - Escola de Engenharia de São Carlos, Universidade de São Paulo.

DEGARMO, E. P.; BLACK, J. T.; KOHSER, R. A. (1997). Materials and processes in manufacturing. 8.ed. Upper Saddler River, NJ, Prentice Hall. 
DERWENT, R.G.; JENKIN, M.E. (1990). Hydrocarbon involvement in photochemical ozone formation in Europe. AERE R 13736, AEA Environment and Energy, Harwell Laboratory, Oxfordshire OX11 ORA, United Kingdon.

DIXON, J. A.; SHERMAN, P. B. (1990). Economic of Protected Areas - A New Look at Benefits and Costs. Londres, Earthscan Publications Limited.

DREYER, L.C.; NIEMANN, A.L.; HAUSCHILD, M.Z. (2003). Comparison of three different LCIA methods: EDIP97, CML2001 and Eco-indicator99: Does it matter which one you choose?. International Journal of Life Cycle Assessment. 8(4). pág.191-200.

EDIP DATABASE (2003). Banco de dados do EDIP. SIMAPRO software. Universidade Técnica da Dinamarca (DTU), Dinamarca.

ELLIOTT, J. A. (1994). An Introduction to Sustainable Development: the developing world. London \& New York, Routledge.

EMPRESA BRASILEIRA DE PESQUISA AGROPECUÁRIA (1997). Emissão de gases de efeito estufa proveniente da queima da cana-de-açúcar. Ministério da Agricultura e do Abastecimento. (Relatório Técnico - EMBRAPA ).

EUROPEAN COMMISSION (1996). Technical guidance documents in support of: The Commission Directive 93/67/EEC on risk assessment for new notified substances and The Commission Regulation (EC) n. 1488/94 on risk assessment for existing substances. Temporary version. Ispra, Italy : European Chemicals Bureau.

FACTOR, G.; LONGIN, E.; MENGIARDI, J.; TELJIGOVIC, M.; VILLANUEVA, A.; WELTON, C. (1998). Life Cycle Assessment of Sugar Production: cane sugar versus beet sugar. Technical University of Denmark (DTU): Report. Course 80410.

FERREIRA, M. E. T. F. (1991). Queimadas da cana-de-açúcar na região de Ribeirão Preto e implicações sobre a saúde da população: Aspectos agronômicos da queimada da cana-de-açúcar. Relatório Técnico da palestra no Centro de Estudos Regionais, Universidade de São Paulo. 22 de out. 
FIC (2004). Teor do álcool hidratado combustível. In: http://www.ficpetroleo.com.br/faq.asp\#resposta3

FEDERAÇÃO DAS INDÚSTRIAS DO ESTADO DE SÃO PAULO (2001). Ampliação da oferta de energia através da biomassa (bagaço de cana-deaçúcar). São Paulo: FIESP - CIESP.

FOLHA DE SÃO PAULO (1999). EUA banem agrotóxico aprovado no Brasil. Folha de São Paulo, São Paulo, 4 de agosto. Caderno Ciência.

FRANKE, C. (2004). Ciclo de vida de produtos. Trabalho desenvolvido entre a Universidade Técnica de Berlin (TUBerlin) e o Grupo de Adequação Ambiental em Manufatura (AMA). See also: http://www.numa.org.br

FREEMAN, H. (1990). Hazardous Waste Minimization. Singapore, McGraw-Hill Book

FREITAS, G. R. (1987). Preparo do solo. In: Paranhos, S. B., coord. Canade-açúcar: cultivo e utilização. 1.ed. Campinas, Fundação Cargill. v.1, p.271283.

GEORGESCU-ROEGEN, N. (1971). The entropy law and the economic process. Cambridge: Harvard University Press.

GIANNANTONI, C. (2002). The maximum em-power principle at the basis for thermodynamics of quality. Padova, Itália, SGEditoriali \& Gainesville, USA, Center for Environmental Policy University of Florida.

GIANNANTONI, C. (2004). Emergia e Exergia: conceitos e aplicações. Entrevista oral concedida durante o IV Biennial International Workshop Advances in Energy Studies, Ecology-Energy Issues in Latin America, organizado pela Universidade Estadual de Campinas - UNICAMP, em Campinas, SP, de 16 a 19 de junho de 2004.

HARLAND, C. (1999). Developing the Concept of Supply Strategy. International Journal of Supply Strategy. v. 19, n. 7, p. 650-673. 
HORLOCK, J. H.(1997). Cogeneration - Combined Heat and Power (CHP). Krieger Publishing Co. p. 226.

HORII, J. (1998). Tecnologia do álcool etílico. Departamento de Tecnologia de Açúcar e Álcool. Escola Superior de Agronomia "Luiz de Queiroz", Universidade de São Paulo. Piracicaba, SP. Notas de aula.

INSTITUTO AGRONÔMICO DE CAMPINAS (1994). Estudo de Caso: Destilarias de álcool e usinas de açúcar. Campinas, Documentos Técnicos. IAC, n.49.

INSTITUTO BRASILEIRO DE GEOGRAFIA E ESTATÍSTICA (2005). Produção agrícola municipal. Quantidade produzida, valor da produção, área plantada e área colhida da lavoura temporária. See also: http://www.sidra.ibge.gov.br/bda (05/01/05).

INTERNATIONAL ORGANIZATION FOR STANDARDIZATION (1997). ISO 14040: Environmental Management - Life cycle assessment - Principles and framework. Geneva, $\mathrm{CH}$ : ISO.

INTERNATIONAL ORGANIZATION FOR STANDARDIZATION (1998). ISO 14041: Environmental Management - Life cycle assessment - Goal and scope definition and life cycle inventory analysis. Geneva, $\mathrm{CH}$ : ISO.

INTERNATIONAL ORGANIZATION FOR STANDARDIZATION (2000a). ISO 14042: Environmental Management - Life cycle assessment - Life cycle impact assessment. Geneva, CH: ISO.

INTERNATIONAL ORGANIZATION FOR STANDARDIZATION (2000b). ISO 14043: Environmental Management - Life cycle assessment - Life cycle interpretation. Geneva, CH: ISO.

JACKSON, T. (1993). Clean Production Strategies: developing preventive environmental management in the industrial economy. USA, Lewis, Stockholm Environment Institute, International Institute for Environmental Technology and Management. 
KOTAS, T.J. (1995). The exergy method of thermal plant analysis. Reprint Edition. Florida, USA, Krieger Publishing Company. 328 p.

KROZER, J.; VIS, J.C. (1998). How to get LCA in the right direction? Journal of Cleaner Production, 6, p.53-61.

KULAY, L. A. (2000). Desenvolvimento de modelo de análise de ciclo de vida adequado às condições brasileiras : aplicação ao caso do superfosfato simples. São Paulo. Dissertação (Mestrado) - Escola Politécnica, Universidade de São Paulo.

LANZOTTI, C.; ORTEGA, E. (1999). Emergy analysis and trends for ethanol production in Brazil. In: Proceedings of the First Biennial Emergy Analysis Conference, University of Florida, Gainesville, Florida, EUA.

LORA, E.S., ARRIETA, F.P., CARPIO, R.C. (2001). Eletricidade a partir do bagaço de cana. In: Mello MG, editor. Biomassa: energia dos trópicos em Minas Gerais. Belo Horizonte: Estudos Preliminares. p. 59-81.

LOTKA, A.J. (1922a). Contribution to the energetics of evolution. Proc. National Academy of Sciences, 8:147-150.

LOTKA, A.J. (1922b). Natural selection as a physical principle. Proc. National Academy of Sciences, 8:151-155.

LOTKA, A.J. (1925). Elements of physical biology. New York: Williams and Wilkins, 465p.

MACEDO, I. C. et al. (2004). Balanço das emissões de gases do efeito estufa na produção e no uso do etanol no Brasil. São Paulo: Governo do Estado de São Paulo, Secretaria do Maio Ambiente. Janeiro.

MACEDO, R.K. (1995). Equívocos e propostas para a avaliação ambiental. In: TAUK, S.M. (org.). Análise Ambiental: Uma Visão multidisciplinar. 2.ed. São Paulo, Editora da Universidade Estadual Paulista. Cap. 2, p.33-44.

MCGRANE, G. G. (1994). An emergy evaluation of personal transportation alternatives. M.Sc. Dissertation - University of Florida, Gainesville. USA.106 p. 
MAGALHÃES, M. (2004). Vendas de carros a álcool e bicombustíveis crescem em agosto. See also: http://www.jornalcana.com.br/conteudo/noticia (27/09/2004).

MAGNANI, M. (2000). Abordagem integrada de aspectos conceituais relacionados à adequação ambiental em manufatura. São Carlos. Dissertação (Mestrado) - Escola de Engenharia de São Carlos, Universidade de São Paulo.

MANZINI, E.; VEZZOLI, C. (2002). O Desenvolvimento de Produtos Sustentáveis. São Paulo: Editora da Universidade de São Paulo.

MARINHO, E. V. A. (1991). Projeto fogo. Journal of atmospheric chemistry, 12, p.87-102.

MARX, K. (1867). El Capital l: Crítica de la Economia Política. México: Fondo de Cultura Económica. Primeira reimpresión, 2000.

MATTAROLO, L. (1996). I Fundamenti della Termodinamica. La Termodinamica Review, jul-ago.

MAY, P. (1995). Economia Ecológica e o Desenvolvimento Equitativo no Brasil. In MAY, P. Economia Ecológica: Aplicações no Brasil. Rio de Janeiro: Campus.

MCINTYRE, K. et al. (1998). Environmental performance indicators for integrated supply chains: the case of Xerox Ltd. Supply Chain Management. MCB University Press. v.3 n.3 p. 149-156.

MELLO, R. (1997). Custos ambientais de agroecossistemas da cana-deaçúcar. São Carlos. Tese (Doutorado) - Escola de Engenharia de São Carlos, Universidade de São Paulo.

MERICO, L.F.K. (1996) Introdução à Economia Ecológica. Blumenau: Editora da Furb.

MIKEL, J. R. (2002). The meaning of life. New Scientist. The exergy machine have we finally found life's true purpose? 5 de outubro. 176 (2363). 
MINISTÉRIO DA CIÊNCIA E TECNOLOGIA (2003). Relatório da produção do setor sucroalcooleiro. In: http:// www.mct.gov.br (15/03/03)

MORAN, M. J. (1989). Availability Analysis: A Guide of Efficient Energy Use. Revised Edition, American Society of Mechanical Engineers, New York.

MORAN, M.J. \& SHAPIRO, H.N. (1995). Fundamentals of Engineering Thermodynamics New York, John Wiley \& Sons Inc. 859p.

MOTTA, R. S. da (1998) Manual para Valoração Econômica de Recursos Ambientais. Ministério do Meio Ambiente, dos Recursos Hídricos e da Amazônia Legal, 218 p.

MUNASHINGHE, M. (1992) Environmental Economics and Valuation in Development Decion Making. World Bank Environmental Working Paper $n^{\circ} 51$, Whashington.

NEBRA, S. A. (2001). Análise de sistemas térmicos pela II Lei da Termodinâmica. Notas de aula. Disciplina de Pós-graduação: Tópicos em Termodinâmica Aplicada, DE-FEM-UNICAMP.

ODUM, E.P. (1988). Ecologia. Rio de Janeiro: Editora Guanabara Koogan S.A. ODUM, H.T. (1971). Environment, Power and Society. New York: John Wiley \& Sons.

(1983). Systems Ecology: An Introduction. New York: John Wiley. 644 p.

(1996). Environmental Accounting, Emergy and Decision Making. New York: John Wiley. 370 p.

OMETTO, A. R. (2000). Discussão sobre os fatores ambientais impactados pelo setor sucroalcooleiro e a certificação socioambiental. São Carlos. Dissertação (Mestrado) - Escola de Engenharia de São Carlos, Universidade de São Paulo. 
OMETTO, A.R.; RAMOS, P.; LOMBARDI, G.; ORTEGA, E.; COMAR, O (2002). Mini-Usinas de Álcool Integradas (Muai) - Avaliação Emergética. AGRENER 2002. IV Encontro de Energia no meio Rural. UNICAMP.Campinas, Sp. Out.

OMETTO, A. R.; ROMA, W. N. L. (2004). Exergy losses from atmospheric emissions produced by the fuel ethanol life cycle in Brazil. $17^{\text {th }}$ International Conference on Efficiency, Costs, Optimization, Simulation and Environmental Impact of Energy Systems - ECOS 2004. México.

OMETTO, A. R.; ROMA, W. N. L.; SCANAVINI, F.L. (2003a). Considerações e Alcance da Avaliação Emergética. IN: WENDLAND, E. SCHALCH, V. Pesquisas em meio ambiente: subsídios para a gestão de políticas públicas. São Carlos, RIMA. CAP.10, P.125-138.

OMETTO, A. R.; ROMA, W. N. L.; SOUZA, M.P.S. (2003b). Environmental Management of Alcohol Fuel with Energy Production using Life-Cycle Analysis (LCA). 16 ${ }^{\text {th }}$ International Conference on Efficiency, Costs, Optimization, Simulation and Environmental Impact of Energy Systems ECOS 2003. Technical University of Denmark - DTU. Copenhagen, Dinamarca, de 30 de junho à 02 de julho.

OMETTO, D. A. (2000). Transcrição de entrevista com o professor titular sobre Engenharia Rural. 20 de julho. ESALQ, USP, Piracicaba,SP.

ONLINE CONVERSION (2003) Conversor de unidade. In: http:// www.onlineconversion.com (10/03/2003)

ORTEGA, E. (2003) Contabilidade e Diagnóstico de Sistemas usando os valores dos recursos expressos em emergia. http://www.unicamp.br /fea/ ortega/ extensao/ resumo.pdf. 30/01/2003.

PAGLIUSO, J.D. (2004). Emissões atmosféricas na combustão do bagaço. Relato oral. Professor do Departamento de Hidráulica e Saneamento. Escola de Engenharia de São Carlos. Universidade de São Paulo. 
PEARCE, D.; MARKANDYA, A.; BARBIER, E. (1989). Blueprint for a green economy. London: Earthscan Pubs.Ltda

PEARCE, D.; TURNER, R. (1990) Economics of Natural Resources and the Environmental. Baltimore: The Johns Hopkins University Press.

PEREIRA, J.T.V.; NEBRA, S.A. (1999). Transformities and exergetic cost - a discussion. First Biennial Emergy Analysis research Conference. Universidade da Flórida, FL, EUA. Set.

PERES, R. (2004). Consulta a Arq. MSc. Pesquisadora do Núcleo Integrado de Bacias Hidrográficas. Departamento de Hidráulica e Saneamento, Escola de Engenharia de São Carlos, Universidade de São Paulo.

PINTO C.P; NEBRA A.S; CORTEZ L.A.B. (2000). Exergetic Analysis of Anaerobic Digestion of Stillage: Case Study in Brazil. In: ECOS Proceedings.

QUADROS, W. J. de. (1991). O 'Milagre Brasileiro' e a Expansão da Nova Classe Média. Campinas: Tese de Doutorado, IE/UNICAMP.

QUADROS, W. J. de; CANUTO, O. (1997). Roteiro de Análise Econômica para o Programa Nacional de Gerenciamento Costeiro. Brasília, Ministério do Meio Ambiente, dos Recursos Hídricos e da Amazônia Legal.

RIGHETTO, G. M. (2001). Capacidade de pagamento e cobrança pelo uso e degradação dos recursos hídricos. Dissertação (Mestrado). São Carlos: Escola de Engenharia de São Carlos, Universidade de São Paulo.

RÍPOLI, T.C.; MIALHE, L.G; BRITO, J.O. (1990). Queima do canavial: o desperdício não mais admissível. Açúcar e Álcool. Economia e Produtividade. v.10, n.54, p.18-22. Jul/ago.

RIPOLI, T. C (2004). Transcrição de relato oral com o professor titular sobre engenharia rural. 26/02.04. ESALQ, USP, Piracicaba, SP

RODRIGUEZ, E. O. (2003). Transcrição de entrevista com o professor titular sobre emergia, transformidade e índices de qualidade termodinâmicos. 11 de maio. UNICAMP, FEA, Campinas, SP. 
ROSEN, M.A.; DINCER, I. (1997). On Exergy and Environmental Impact. Int. J. Energy Res, n. 21. p. 643-654.

ROSEN, M. A.; DINCER, I. (1999). Exergy analysis of waste emissions. International Journal of Energy Research. n. 23. p. 1153 - 1163.

SACHS, I. (1993). Estratégias de Transição para o Século XXI: Desenvolvimento e Meio Ambiente. São Paulo: Studio Nobel, Fundação do Desenvolvimento Administrativo (Cidade Aberta).

SAFFIOTI, W. (1985). O desperdício da energia na queima dos canaviais. Revista Pau Brasil, n.9, ano II, p.41-45. nov/dez.

SCHALTEGGER, S. org (1996). Life cycle assessment (LCA) - Who vadis? Basel, Boston, Berlin, Birkhäuser Verlag.

SCIENCEMAN, D.M. (1989). The emergence of emonomies. Proceeding. The International Society for Social System Science. 33 rd . Meeting. Edimburg. Vol III.

SCIUBBA, E. (1999). Exergy as a measure of environmental impact. In: Proc. ASME-IMECE'99, Nashville, TN.

SOCIETY OF ENVIRONMENTAL TOXICOLOGY AND ENVIRONMENTAL (1991). A techinical Framework for Life-Cycle assesment. Washington DC: SETAC.

SILVA, M.R.S. (1998). Simpósio: Saúde e Meio Ambiente. (fita cassete) Ribeirão Preto. Departamento de Clínica Médica da Faculdade de Medicina, da Universidade de São Paulo, USP. 28 de maio. 4 fitas cassetes

SLACK, N. et al. (1998). Operations Management. London: Pitman Publishing. $2^{\text {nd }}$ ed.

SOUZA, M.P. (1993). Metodologia de Cobrança sobre os Usos da Água e sua aplicação como Instrumento de Gestão. São Paulo. Tese (Doutorado) Faculdade de Saúde Pública, Universidade de São Paulo. 
(1996). Texto de apoio às aulas para o curso de graduação de arquitetura e urbanismo da EESC-USO. São Carlos (mimeografado).

(2000). Instrumentos de Gestão Ambiental: Fundamentos e Prática. São Carlos, Riani Costa.

(2004). Instrumentos de Recursos Hídricos. Aula Ministrada na Escola de Engenharia de São Carlos, Universidade de São Paulo, São Carlos, SP, $17 / 03 / 04$.

SZARGUT, J. (1999). Exergy analysis of thermal processes; ecological cost. In: Proceedings of the International Workshop "Advances in Energy Studies: energy flows in ecology and economy. Porto Venere, Itália.

SZARGUT, J.; MORRIS, D.R.; STEWARD, F.R. (1988). Exergy analysis of thermal, chemical, and metallurgical process. New York, Hemisphere Publishing Co.

SZMRECSÁNYI, T. (1994). Tecnologia e degradação ambiental: O caso da Agroindústria canavieira no Estado de São Paulo. Informações Econômicas, v.24, n.10, p.73-81.

TOLBA, M. K. (1982). Development without destruction: envolving environmental perceptions. Dublin, Ireland, Tycooly International Publishing LTDA.

TORRES, E.A. (1999). Avaliação Exergética e Termoeconômica de um Sistema de Cogeração de um Pólo Petroquímico. Campinas. Tese (Doutorado). Faculdade de Engenharia Mecânica, Universidade Estadual de Campinas.

UDO DE HAES, H. A. et al., editor (2002). Life-Cycle Impact Assessment: Striving towards Best Practice. Society of Environmental Toxicology and Chemistry (SETAC). ISBN 1-880611-54-6

UNIÃO DA AGROINDÚSTRIA CANAVIEIRA DE SÃO PAULO (2004). Referência e Estatísticas UNICA. See also: http://www.portalunica.com.br/referencia/estatisticas.jsp (27/09/04). 
UNITED NATIONS INDUSTRIAL DEVELOPMENT ORGANIZATION (1997). Towards a cleaner and mores profitable sugar industry. Austria: Marcia Hill. UNIDO. v. 1 e 2 .

VICTORIA, R. F. (1993). Controle de plantas daninhas na cultura da cana-deaçúcar. Curso de produção de cana-de-açúcar. Piracicaba, SP. Escola Superior de Agricultura "Luiz de Queiroz", Universidade de São Paulo.

WARK, K. Jr. (1995). Advanced Thermodynamics for Engineers. Mc Graw-Hill, Inc. Series in Mechanical Engineering. New York, USA.

WENZEL, H.; HAUSCHILD, M.; ALTING, L. (1997). Environmental Assessment of Products. Bonton/Dordrecht/London: Kluwer Academic Publisehrs. v.1 e 2.

WENZEL, H.; HAUSCHILD, M.; JORGENSEN, J.; ALTING, L. (1994). Environmental tools in product development. Proceedings of the 1994 IEEE International Symposium on Eletrocnics \& the Environment. San Francisco, USA.p.100-108.

WORLD BUSINESS COUNCIL FOR SUSTAINABLE DEVELOPMENT (2004). The WBCSD on Eco-eficciency. In: http://www.wbcsd.ch (20/12/2004).

YANTOVSKII, E.I. (1994). Energy and Exergy Currents (An Introduction to Exergonomics). Niva Science Publishers, Inc. New York. 